University of Rhode Island

DigitalCommons@URI

Open Access Master's Theses

2003

An Assessment of Regulatory and Planning Measures Affecting

Land Conservation and Resource Protection in Eight Rhode Island

Towns: Charlestown, Coventry, Exeter, Hopkinton, Richmond,

South Kingstown, Westerly, and West Greenwich

Patricia S. Hickey

University of Rhode Island

Follow this and additional works at: https://digitalcommons.uri.edu/theses

Recommended Citation

Hickey, Patricia S., "An Assessment of Regulatory and Planning Measures Affecting Land Conservation and Resource Protection in Eight Rhode Island Towns: Charlestown, Coventry, Exeter, Hopkinton,

Richmond, South Kingstown, Westerly, and West Greenwich" (2003). Open Access Master's Theses. Paper 750.

https://digitalcommons.uri.edu/theses/750

This Thesis is brought to you for free and open access by DigitalCommons@URI. It has been accepted for inclusion in Open Access Master's Theses by an authorized administrator of DigitalCommons@URI. For more information, please contact digitalcommons-group@uri.edu. 


\section{An Assessment of Regulatory and Planning Measures Affecting Land Conservation and Resource Protection In Eight Rhode Island Towns:}

Charlestown, Coventry, Exeter, Hopkinton, Richmond, South Kingstown, Westerly, and West Greenwich

BY

PATRICIA S. HICKEY

A RESEARCH PROJECT SUBMITTED IN

PARTIAL FULFILLMENT OF THE REQUIREMENTS

FOR THE DEGREE OF MASTER OF COMMUNITY PLANNING

UNIVERSITY OF RHODE ISLAND

2003 


\section{An Assessment of Regulatory and Planning Measures Affecting Land Conservation and Resource Protection In Eight Rhode Island Towns:}

Charlestown, Coventry, Exeter, Hopkinton, Richmond, South Kingstown, Westerly, and West Greenwich

Research Project

Of

Patricia S. Hickey

Approved:

Major Professor

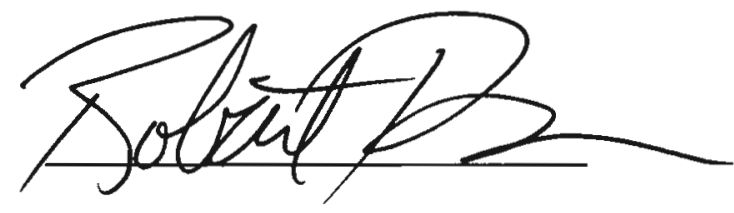

Acknowledged:

Director

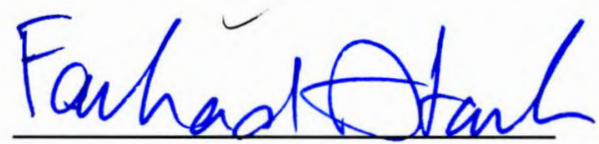




\section{Acknowledgments:}

Acknowledgments:

I would like to thank my Professional Project Committee:

Rob Thompson, PhD., JD. URI Community Planning \& Landscape Architecture:

Major Professor

Sheila Brush, Program Director, Grow Smart Rhode Island: Reader

Howard Foster, PhD. URI Community Planning \& Landscape Architecture: Reader

As well as:

Meg Kerr and Virginia Lee at the URI Coastal Resources Center; and

Sheila Brush, Scott Millar, Jim Lucht, Howard Foster, Kathy Crawley, Mike Deluca

and Richard Youngken for their assistance in the design of this study.

A special thanks to the Charlestown, Coventry, Exeter, Hopkinton, Richmond, South Kingstown, Westerly, and West Greenwich Planning Departments for their participation in this study. 


\section{Table of Contents:}

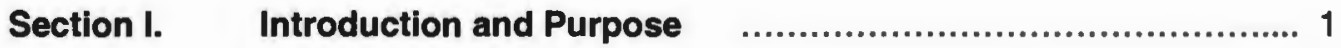

Section II. Town Profiles $\quad$.............................................. 5

Town of Charlestown Profile.............................................................. 6

Town of Coventry Profile................................................................. 26

Town of Exeter Profile......................................................................47

Town of Hopkinton Profile.................................................................. 63

Town of Richmond Profile................................................................. 79

Town of South Kingstown Profile......................................................... 93

Town of West Greenwich Profile...........................................................110

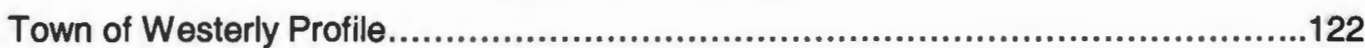

Section III. Town Regulatory Comparisons $\quad$....................................138

Charlestown, Coventry, Exeter, Hopkinton Matrix ........................................138

Richmond, South Kingstown, West Greenwich, Westerly Matrix ........................159

Appendix A List of Plans, Ordinances, and Land Development Regulations.....172

Appendix B Municipal Planners...................................................... 173 


\section{Section I. Introduction \& Purpose}

The purpose of this study was to assess planning capacity for land conservation and natural resource protection in eight Rhode Island municipalities based on factors such as community comprehensive planning goals and objects, zoning and subdivision regulations, technical capacity and staffing considerations. The main body of this report is comprised of detailed matrices inventorying land conservation and resource protection efforts for the individual towns. The last section of the report is comprised of two matrices comparing zoning and land development regulations in each of the eight towns. The matrices are organized by resource area and applicable development regulations.

This assessment provides only a snapshot of the planning and regulatory milieus in the eight towns during the period of June to December 2000. The results of this study will be used to build planning capacity in the towns under study through targeted educational and funding opportunities. The information in this study is proprietary, and should not be used or cited without permission of the author.

The criteria used to assess planning capacity were largely derived from an inventory of comprehensive plan objectives and development regulations. The study also included in-depth interviews with town planners on implementation efforts. These interviews provided important information on the technical and professional capacity within planning departments, as well as insight into how well the towns are actually managing development. The interviews were also beneficial in helping to gauge levels of awareness and consensus among town decision-makers concerning the significance of land conservation and natural resource protection to growth management efforts. 
It became apparent throughout the interview process, that a town's planning capacity is greatly influenced by the level of consensus among town decisionmakers. Low technical and staffing capacity does not preclude high capacity to manage development. For example, the Town of Richmond lacks a fulltime planner and GIS capability. This rather low in-house capacity, given current rates of growth, is offset by a high level of commitment to land conservation and natural resource protection among town decision-makers. The Town of Richmond's development regulations and practices reflect this commitment. According to the town planner, Richmond's capacity to manage development is high.

The adoption and implementation of strong development regulations can also compensate for limited in-house professional and technical capacity. In towns that lack full GIS capacity, and hence the ability to view environmental characteristics on a parcel basis, developers can be required to provide environmental impact statements as part of site review requirements in the zoning ordinance. Towns can also require developers to provide a site analysis demonstrating how environmental considerations will be incorporated into the design of the site. Towns can also hire environmental consultants to conduct impact assessments. For example, the Town of Coventry contracts with a non-profit organization that is staffed by environmental management professionals to assist the town in conducting indepth environmental assessments for development proposals.

Towns with mandatory residential cluster development ordinances, such as Charlestown and Richmond, have the greatest degree of flexibility and the highest level of consistency in siting development away from environmentally sensitive areas. For example, both towns use their mandatory cluster ordinance to site development away from wetlands and water bodies, in effect, creating extended vegetative buffer zones for these resources in town. Mandatory cluster has also been used to plan and create linked greenspaces 
in one of the towns. Coventry's cluster ordinance includes a 20 percent density bonus for farmland preservation.

Subdivision and land development regulations specifying "land unsuitable for development" is another important way for the towns to preserve open spaces and protect fragile ecosystems during the development process. Land defined as unsuitable for development is deducted from the buildable acreage of the parcel. Charlestown's regulation is the most protective and far reaching, and provides an excellent example of how towns can increase their capacity to protect natural resources and fragile or important land. Exeter is the only town in the study area that does not specify "land unsuitable for development".

The town profiles included in this report identify planning capacity limitations on a town-by-town basis. The eight towns in the study vary widely in their capacity to manage growth in an environmentally sensitive manner. $A$ surprising conclusion of this assessment is that low technical and staffing capacity does not preclude high capacity to manage development. Comprehensive development regulations requiring detailed environmental assessments and site analysis can offsite a number of in-house capacity limitations. The towns with the highest level of planning capacity, in this study, also possessed the most experienced and proactive planning officials.

Broad-based consensus among town officials on the need to manage growth through land conservation and natural resource protection efforts may be the single most important variable in assessing a town's planning capacity for purposes of this study. Based on these findings, efforts to build planning capacity should focus on education and training programs for town officials, particularly for planning board and commission members. The comparative regulatory matrix created for this study indicates a high degree of cross-town sharing of development regulations. Capacity building efforts should focus on facilitating cross-town learning wherever possible. 
This report concludes that the most important indicators of planning capacity are: 1) consensus among town officials regarding the significance of land conservation and natural resource protection, 2) an experienced and proactive planning board or commission, and 3) comprehensive, environmental development regulations. 


\section{Section II. Town Profiles}

The town profiles include a narrative assessment of planning capacity along with two matrices inventorying comprehensive planning objectives and implementation efforts and regulatory measures and implementation efforts. The matrices are organized by natural resource area and applicable development regulations or plan objectives. In order to create each matrix, community comprehensive plans, zoning ordinances, and subdivision and land development regulations were reviewed for each town. Information was then transcribed into the matrices. Although detailed citations are not provided due to space limitations, headings are provided to indicate where the information is located in municipal planning documents.

The narrative assessment in each town profile is organized into five principal sections: an overall summary, information on planning staff and resources, an assessment of comprehensive plan objectives, GIS capacity and site analysis protocols, and lastly, land development regulations. The views or judgments expressed in these assessments are solely those of the author, and should not be read as authoritative statements of fact. 


\section{TOWN OF CHARLESTOWN PROFILE}

\section{Summary}

Based on the criteria used in this study, Charlestown has one the most comprehensive approaches to natural resources protection and land conservation in the study area. The majority of the Town's comprehensive plan objectives for land conservation and natural resources protection, as setforth in the 1992 plan, have all been implemented. The Town's zoning and subdivision regulations further reflect a commitment to protecting natural resources and open spaces. The Town's present planning capacity to manage development is high.

The town is unique in that the planning commission is an elected body. The commission has enacted some of the most progressive subdivision and land development regulations in the study area. For example, Charlestown is one of only two towns that mandate cluster development for all major subdivisions. The Town's subdivision and land development regulation, which classifies land that is "unsuitable for development," is also the most far-reaching. Charlestown is one of only two towns in the study area that requires developers to obtain a certified letter from the Rhode Department of Environmental Management, Natural Heritage Program documenting the presence or absence of rare or endangered species.

There is widespread consensus in the Town on the need to preserve open space and to protect the water resources. The town is currently working with the university and state agencies on a number of projects to increase water quality management, including the establishment of a wastewater management commission. The planning commission is presently working on a new open space acquisition plan for the town. 


\section{Planning Department}

The Charlestown Planning Department, under the current town planner, possesses a high level of both professional and technical capacity. The town planner (now gone) has a strong background in, and commitment to, natural resource protection. Charlestown is one of the few towns in the study area with adequate GIS technical capacity. The Town's plat maps have been digitized, and the planner has easy access to GIS coverages of critical resource areas and 'environmental constraints' to development on both a town-wide and parcel basis.

The town planner works almost exclusively with the planning commission. As an elected body, the commission assumes responsibility for planning decisions in town. Both the planning commission and the zoning board of review have their own solicitors to prevent conflicts of interest in the development process.

Planning capacity limitations are primarily due to a lack of resources for planning functions. The town employs a single, full-time planner to handle all day-to-day planning functions. Planning officials need more assistance identifying "model ordinances" and other innovative techniques for guiding development. There is also a need for institutionalized training program for all new board and commission members as well as for town solicitors. It appears that the town, particularly the planning commission, is open to strengthening environmental protections and growth management provisions.

\section{Comprehensive Plan Objectives}

The Town of Charlestown Comprehensive Plan was adopted by the town council in January of 1992 . The plan provides a focused agenda for natural resource protection, with an emphasis on water resources. In regard to broader land conservation objectives, the plan does not offer a town-wide vision or greenspace concept plan. Land acquisition strategies mentioned in 
the plan are mainly focused on the protection of specific resources such as wetlands and water bodies. Suggested policies for land acquisition revolve around the preservation of protective buffer zones for critical resource areas.

The Town's comprehensive plan objectives strongly encourage increased municipal involvement with local and state environmental organizations. The plan also strongly supports increasing public education and participation around environmental issues, as well as increased public access to the Town's natural resources and open spaces.

The plan consistently promotes changes in subdivision/land development regulations and zoning to increase environmental protection measures. The inclusion of such policy goals in the plan provides an important basis for future regulatory actions. Charlestown has adopted or is pursuing the majority of its comprehensive plan objectives. The plan appears to be an important guidance document for land conservation and natural resources protection, as reflected in regulatory changes since the adoption of the plan.

\section{Site Analysis}

Charlestown's in-house GIS capacity greatly assists the town planner in conducting early environmental assessments of proposed sites for development. Easy access to detailed site maps allows the town planner to address important site considerations with developers prior to the preapplication meeting and the drafting of conceptual plans. This saves developers both time and resources, and provides town officials more influence in the design of the site. The town planner would like to have this process formally adopted into regulatory procedures by requiring developers to initiate the review process with detailed two foot contour maps in-hand. In this way, siting decisions would formally begin with a consideration of the natural characteristics of the parcel. 
Town-produced maps also assist the planner and the commission in conducting onsite analysis. GIS mapping of parcel constraints direct attention to specific areas of the site, such as wetlands or important habitat, it also enables town officials to see the site in the context of adjoining properties and/or nearby areas of environmental concern. Ultimately, in-house mapping capacity greatly reduces the planning commission's dependence on developers for complete and accurate site information. It also provides town officials with a sound foundation on which to base concerns and conditions of approval early in the development review process.

\section{Zoning and Subdivision Regulations}

\section{Zoning Ordinances}

- Farmland Zoning-none

- Residential Cluster Development--Charlestown is one of two towns in the study area that mandates residential cluster development for all major subdivisions. The cluster provisions require that 40 percent of the total land area must be protected as open space, 50 percent of which may be land "unsuitable for development." The planner felt that the cluster provisions could be made stronger, particularly through the adoption of better site analysis and site design standards.

- Overlay Districts-Charlestown's zoning ordinance includes two protection districts--the Flood Hazard Overlay District and the Groundwater Protection Overlay District. Nancy Hess considers the Town's Groundwater Protection Overlay District to be a model ordinance. The town is also in the process of implementing a wastewater management district.

- Site Plan Review-The town has adopted detailed environmental standards for all land developments under its Site Plan Review Ordinance.

- Performance Standards-The town has adopted its own septic system setback requirements from water bodies, fresh and coastal wetlands, and flood hazard areas. The planning commission has the authority to increase the criteria where necessary. 


\section{Subdivision and Land Development Regulations}

By comparison to other towns in the study area, Charlestown's subdivision and land development regulations provide the most comprehensive suite of regulatory provisions designed to protect natural resources during the development process.

- Land Unsuitable for Development--The Town's list of land unsuitable for development is the most detailed and far-reaching in comparison with other towns in the study area. Land unsuitable for development shall be deducted from the developable acreage of the parcel--resource areas subject to protective setback distance such as but not limited to, wetlands; areas subject to storm flow or flooding; hydric soils and inter-tidal salt marshes; land located in any $V$ zones or floodways; any area of the track proposed to be developed equal to the area of any street and/or utility rights-of-way; any unique sites having historical, archeological values or protected species of flora or fauna; any other lands which if developed would cause a threat to public health, or result in irreparable public harm, or loss of irreplaceable resources; any area of ledge and/or rock outcrops at/or within four feet of the land surface, any area where slopes exceed fifteen percent)

- Environmental Analysis--An environmental analysis is required for all major subdivisions and land developments as well as for any development occurring in proximity to significant natural resources. The list of natural resources covered under this regulation extends to all of the natural resource areas addressed in this study.

- Erosion and Sediment Control--An erosion and sediment control plan is required for all major subdivisions and land developments and for all development occurring in close proximity to wetlands, water resources or on sites with steep slopes. According to the planner, the public works director and the building inspector strictly monitor and enforce erosion and sediment control plans.

- Site Design Standards--The Town's Physical Design and Public Improvement Standards are comprehensive and detailed. The Town's mandatory cluster provision provides the town with the flexibility it needs to implement basic design standards. Of particular note, the standards include a provision that states: "excess cutting, filling or stripping vegetation shall not be permitted." However, parcels of five acres or less do not require a clearing permit from the Rhode Island Department of Environmental Management. Oftentimes, owners of these parcels will strip the property of trees and vegetation prior to initiating the development review process. 


\section{Charlestown Comprehensive Plan Matrix}

\begin{tabular}{|l|l|l|}
\hline Issue Area & $\begin{array}{l}\text { Comprebensive Planning } \\
\text { Objective }\end{array}$ & Implementation \\
\hline
\end{tabular}

\begin{tabular}{|c|c|c|}
\hline $\begin{array}{l}\text { Farmland } \\
\text { Preservation }\end{array}$ & & \\
\hline \multicolumn{3}{|l|}{$\begin{array}{l}\text { Open Space } \\
\text { Zoning }\end{array}$} \\
\hline & $\begin{array}{l}\text { Rezone all conservation lands } \\
\text { held by public agencies to Open } \\
\text { Space, Conservation and } \\
\text { Recreation }\end{array}$ & $>$ Adopted \\
\hline \multicolumn{3}{|l|}{$\begin{array}{l}\text { Open Space } \\
\text { Preservation }\end{array}$} \\
\hline & $\begin{array}{l}\text { Develop a land trust for } \\
\text { conservation purposes }\end{array}$ & $\begin{array}{l}\text { Began the South County Conservancy } \\
\text { (which is now independent) }\end{array}$ \\
\hline & $\begin{array}{l}\text { Acquire additional open space } \\
\text { land...with a focus on providing } \\
\text { buffers and/or limited access to } \\
\text { natural resources }\end{array}$ & $\begin{array}{l}\text { This was accomplished using DEM's } \\
1990 \text { Open Space Grants. The town } \\
\text { currently has a grant proposal in with } \\
\text { DEM for continued open space } \\
\text { acquisition. } \\
\text { The Planning Commission is currently } \\
\text { working on an Open Space Plan for the } \\
\text { town. }\end{array}$ \\
\hline & $\begin{array}{l}\text { - Rezone the 5-acre residential } \\
\text { zone to 3-acre residential }\end{array}$ & $>$ Adopted \\
\hline & $\begin{array}{l}\text { Continue requiring exactions of } \\
\text { developers to preserve open } \\
\text { space, especially as undeveloped } \\
\text { buffers to natural resources. } \\
\text { Continue encouraging clustered } \\
\text { developments with surrounding } \\
\text { open space. }\end{array}$ & $\begin{array}{l}\text { Pursued through open space provisions } \\
\text { in mandatory cluster, and in designation } \\
\text { of land unsuitable for development. }\end{array}$ \\
\hline & $\begin{array}{l}\text { Continue to cooperate with } \\
\text { agencies such as the Wood } \\
\text { Pawcatuck Association and pond } \\
\text { watcher groups in educational } \\
\text { activities and preservation of } \\
\text { undeveloped parcels }\end{array}$ & $>$ Actively pursued \\
\hline
\end{tabular}




\section{Charlestown Comprehensive Plan Matrix}

\begin{tabular}{|l|l|l|}
\hline Issue Area & $\begin{array}{l}\text { Comprehensive Planning } \\
\text { Objective }\end{array}$ & Implementation \\
\hline
\end{tabular}

\begin{tabular}{|c|c|c|}
\hline $\begin{array}{l}\text { Natural } \\
\text { Resource } \\
\text { Protection }\end{array}$ & & \\
\hline & $\begin{array}{l}\text { Promote access to and } \\
\text { appreciation of many of the } \\
\text { natural resources as appropriate } \\
\text { through the continued } \\
\text { development of shore access } \\
\text { points, hiking paths, and other } \\
\text { opportunities for outdoor } \\
\text { activities. }\end{array}$ & \\
\hline & $\begin{array}{l}\text { - Identify areas for increased } \\
\text { protection through dedication or } \\
\text { acquisition of development } \\
\text { rights or property. Promote } \\
\text { acquisition of these sites by the } \\
\text { town, land trust, or other } \\
\text { conservation organization... }\end{array}$ & $\begin{array}{l}\text { The town works with the South County } \\
\text { Conservancy, TNC etc...to protect and } \\
\text { acquire critical land }\end{array}$ \\
\hline & $\begin{array}{l}\text { Continue educational efforts and } \\
\text { group activities that raise } \\
\text { awareness of environmental } \\
\text { protection, e.g., septic system } \\
\text { brochure, Conservation } \\
\text { Commission sponsored clean- } \\
\text { ups, or activities for school } \\
\text { children }\end{array}$ & $\begin{array}{l}\text { The town actively works with URI, state } \\
\text { agencies and other organizations to } \\
\text { protect natural resources through } \\
\text { increased public awareness and } \\
\text { participation } \\
\text { The town has a Wastewater Management } \\
\text { Commission. }\end{array}$ \\
\hline & $\begin{array}{l}\text { Manage growth and } \\
\text { development to reflect the } \\
\text { natural characteristics (resources } \\
\text { and constraints) of the land }\end{array}$ & $\begin{array}{l}\text { Adopted in subdivision and land } \\
\text { development regulations }\end{array}$ \\
\hline & $\begin{array}{l}\text { Explore altemative measures of } \\
\text { resources protection as they } \\
\text { become available or feasible, } \\
\text { including alternative flexible } \\
\text { zoning measures, and the use of } \\
\text { altemative technologies to } \\
\text { remove nutrients from } \\
\text { wastewater. }\end{array}$ & Pursued \\
\hline
\end{tabular}




\section{Charlestown Comprehensive Plan Matrix}

\begin{tabular}{|l|l|l|}
\hline Issue Area & $\begin{array}{l}\text { Comprehensive Planning } \\
\text { Objective }\end{array}$ & Implementation \\
\hline
\end{tabular}

\begin{tabular}{|c|c|c|}
\hline Wetlands & & \\
\hline & $\begin{array}{l}\text { Work with adjacent communities } \\
\text { and the Tribe to define the } \\
\text { appropriate character of key } \\
\text { resources and to cooperate in } \\
\text { protecting them }\end{array}$ & \\
\hline & $\begin{array}{l}\text { Develop a planner's database, } \\
\text { combining environmental/ } \\
\text { cultural resources and } \\
\text { constraints maps with lot } \\
\text { information to be used as a "red } \\
\text { flag" in reviewing developments }\end{array}$ & $\begin{array}{l}\text { Yes. Parcel data is digitized and used } \\
\text { along with GIS data layers created by the } \\
\text { EDC. Mary Hutchinson digitized the } \\
\text { parcel maps and created an ArcView } \\
\text { Project for the town }\end{array}$ \\
\hline & $\begin{array}{l}\text { Preserve vegetated buffers } \\
\text { between land uses and roads, } \\
\text { streams and wetlands }\end{array}$ & $>$ Pursued through site design standards \\
\hline $\begin{array}{l}\text { Watercourse/ } \\
\text { Surface } \\
\text { Waters }\end{array}$ & & \\
\hline & $\begin{array}{l}\text { Develop additional provisions } \\
\text { for water resource protection } \\
\text { through zoning and other land } \\
\text { use management tools (such as } \\
\text { water quality performance } \\
\text { standards and enforcement of } \\
\text { state vegetated setbacks from } \\
\text { streams and wetlands }\end{array}$ & $\begin{array}{l}\text { Stormwater Management Plans required } \\
\text { for all development } \\
\text { Performance Standards adopted } \\
\text { Wastewater Management District } \\
\text { adopted } \\
\quad \text { Site design standards }\end{array}$ \\
\hline & $\begin{array}{l}\text { Monitor water quality in the } \\
\text { fresh water bodies and salt } \\
\text { ponds through the volunteer } \\
\text { pond watchers groups' efforts } \\
\text { and other studies, identifying } \\
\text { specific problems or } \\
\text { improvements, and where } \\
\text { necessary researching and } \\
\text { implementing feasible } \\
\text { improvements that remedy } \\
\text { specific problems identified }\end{array}$ & $\begin{array}{l}\text { Actively collaborates with Cooperative } \\
\text { Extension, Water Quality Program and } \\
\text { state agencies to monitor and protect } \\
\text { water resources }\end{array}$ \\
\hline & $\begin{array}{l}\text { Promote establishing protective } \\
\text { undeveloped zones along water } \\
\text { resources and other habitats } \\
\text { through the use of setbacks, } \\
\text { design standards, exactions, } \\
\text { open space dedication, and } \\
\text { where necessary the purchase of } \\
\text { development rights or property }\end{array}$ & $\begin{array}{l}\text { Pursued through site design standards } \\
\text { and mandatory cluster provisions } \\
\text { Pursued through delimiting "land } \\
\text { unsuitable for development" }\end{array}$ \\
\hline
\end{tabular}




\section{Charlestown Comprehensive Plan Matrix}

\begin{tabular}{|l|l|l|}
\hline Issue Area & $\begin{array}{l}\text { Comprehensive Planning } \\
\text { Objective }\end{array}$ & Implementation \\
\hline
\end{tabular}

\begin{tabular}{|c|c|c|}
\hline \multicolumn{3}{|l|}{$\begin{array}{l}\text { Groundwater } \\
\text { \& Recharge } \\
\text { Areas }\end{array}$} \\
\hline & $\begin{array}{ll}\text { - } & \text { Adopt a Groundwater } \\
& \text { Protection Overlay District }\end{array}$ & Adopted \\
\hline & $\begin{array}{l}\text { Implement a "Wastewater } \\
\text { Management District" }\end{array}$ & $>$ Adopted \\
\hline & $\begin{array}{l}\text { Develop and implement a soil } \\
\text { erosion and sediment control } \\
\text { ordinance }\end{array}$ & $>$ Adopted \\
\hline & $\begin{array}{l}\text { Develop additional provisions } \\
\text { for water resource protection } \\
\text { through zoning and other land } \\
\text { use management tools }\end{array}$ & $\begin{array}{l}>\text { Strict Performance Standards adopted } \\
>\text { Stormwater Management Plans } \\
>\text { Site design standards } \\
>\text { Site Plan Review } \\
>\text { Erosion and Sediment Control Plan }\end{array}$ \\
\hline \multicolumn{3}{|l|}{ Floodplains } \\
\hline \multirow[t]{3}{*}{$\begin{array}{l}\text { Coastal } \\
\text { Features }\end{array}$} & $\begin{array}{l}\text { Define the seaward setbacks } \\
\text { along the barrier beach } \\
\text { communities to be the most } \\
\text { severe erosional dune scarp } \\
\text { (edge) i.e., the erosional scarp } \\
\text { from the blizzard of } 1978 \text { or } \\
\text { more severe erosion after } 1978\end{array}$ & $>$ Adopted \\
\hline & $\begin{array}{l}\text { Promote access to and } \\
\text { appreciation of many of the } \\
\text { natural resources as appropriate } \\
\text { through the continued } \\
\text { development of shore access } \\
\text { points, hiking paths, and other } \\
\text { opportunities for outdoor } \\
\text { activities. }\end{array}$ & \\
\hline & $\begin{array}{l}\text { Monitor water quality in the } \\
\text { fresh water bodies and salt } \\
\text { ponds through the volunteer } \\
\text { pond watchers groups' efforts } \\
\text { and other studies, identifying } \\
\text { specific problems or } \\
\text { improvements, and where } \\
\text { necessary researching and } \\
\text { implementing feasible } \\
\text { improvements that remedy } \\
\text { specific problems identified }\end{array}$ & $\begin{array}{l}\text { Actively collaborates with Cooperative } \\
\text { Extension, Water Quality Program and } \\
\text { state agencies to monitor and protect } \\
\text { water resources }\end{array}$ \\
\hline
\end{tabular}




\section{Charlestown Comprehensive Plan Matrix}

\begin{tabular}{|l|l|l|}
\hline Issue Area & $\begin{array}{l}\text { Comprehensive Planning } \\
\text { Objective }\end{array}$ & Implementation \\
\hline
\end{tabular}

\begin{tabular}{|c|c|c|}
\hline Topography & $\begin{array}{l}\text { Develop and implement a soil } \\
\text { erosion and sediment control } \\
\text { ordinance }\end{array}$ & $D$ Adopted \\
\hline \multirow[t]{2}{*}{$\begin{array}{l}\text { Rare Species/ } \\
\text { Critical } \\
\text { Habitat }\end{array}$} & $\begin{array}{l}\text { Develop a planner's database, } \\
\text { combining environmental/ } \\
\text { cultural resources and } \\
\text { constraints maps with lot } \\
\text { information to be used as a "red } \\
\text { flag" in reviewing developments }\end{array}$ & $\begin{array}{l}\text { GIS with EDC Critical Lands Coverage } \\
\text { including DEM's Natural Heritage Sites }\end{array}$ \\
\hline & $\begin{array}{l}\text { Promote establishing protective } \\
\text { undeveloped zones along water } \\
\text { resources and other habitats } \\
\text { through the use of setbacks, } \\
\text { design standards, exactions, } \\
\text { open space dedication, and } \\
\text { where necessary the purchase of } \\
\text { development rights or property }\end{array}$ & $\begin{array}{l}>\text { Pursued through site design standards } \\
\text { and mandatory cluster provisions } \\
\text { Pursued through delimiting "land } \\
\text { unsuitable for development" }\end{array}$ \\
\hline \multicolumn{3}{|l|}{$\begin{array}{l}\text { Trees/ } \\
\text { Woodlands }\end{array}$} \\
\hline & $\begin{array}{l}\text { - See above (Rare Species/Critical } \\
\text { Habitat) }\end{array}$ & \\
\hline \multirow{2}{*}{\multicolumn{3}{|c|}{$\begin{array}{l}\text { Cultural and } \\
\text { Historic } \\
\text { Resources } \\
\text { Village/Rural } \\
\text { Character }\end{array}$}} \\
\hline & & \\
\hline & $\begin{array}{l}\text { Eliminate 'spot' zones, which } \\
\text { may allow redevelopment that is } \\
\text { inconsistent with surrounding } \\
\text { land uses and natural resources }\end{array}$ & Implemented \\
\hline & $\begin{array}{l}\text { Recommends Village District } \\
\text { Overlay }\end{array}$ & Combined with Historic District \\
\hline & - Historic Districts & Combined with Village District \\
\hline & - Scenic Road Designations & $>$ Reserved in Zoning Regulations \\
\hline & - Roadside Standards & $>$ Not successfully adopted \\
\hline & $\begin{array}{l}\text { Ensure that town staff and the } \\
\text { boards and commissions that } \\
\text { review land development } \\
\text { proposals have adequate } \\
\text { mapping to make well } \\
\text { considered land use decisions }\end{array}$ & $>$ Implemented \\
\hline
\end{tabular}




\section{Charlestown Comprehensive Plan Matrix}

\begin{tabular}{|l|l|l|}
\hline Issue Area & $\begin{array}{l}\text { Comprehensive Planning } \\
\text { Objective }\end{array}$ & Implementation \\
\hline
\end{tabular}

\begin{tabular}{|l|l|l|}
\hline $\begin{array}{l}\text { Village/Rural } \\
\text { Character } \\
\text { (continued) }\end{array}$ & \begin{tabular}{l} 
- $\begin{array}{l}\text { Maintain the current general } \\
\text { patterns, scale, and densities of } \\
\text { development, with the most dense } \\
\text { development occurring in villages } \\
\text { and generally low density } \\
\text { development occurring outside the } \\
\text { village areas }\end{array}$ \\
\hline
\end{tabular} & $\begin{array}{l}\text { Done through zoning (i.e., zoning } \\
\text { reflects traditional land use pattems) }\end{array}$ \\
\hline $\begin{array}{l}\text { Preserve important views and visual } \\
\text { access to the water. Design } \\
\text { standards along Routes 1 and 1A, } \\
\text { Charlestown Beach Road, East } \\
\text { Beach, West Beach Road, and at } \\
\text { important viewing locations along } \\
\text { the Pawcatuck should specify } \\
\text { preservation of views, design of } \\
\text { buildings to be screened by } \\
\text { topography or vegetation where } \\
\text { possible." }\end{array}$ & $>$ No \\
\hline
\end{tabular}


Charlestown Municipal Protections

\begin{tabular}{|l|l|l|}
\hline Issue Area & Municipal Protection Measures & Implementation \\
\hline
\end{tabular}

\begin{tabular}{|c|c|c|}
\hline $\begin{array}{l}\text { Land } \\
\text { Conservation }\end{array}$ & & \\
\hline \multicolumn{3}{|l|}{$\begin{array}{l}\text { Farmland } \\
\text { Preservation }\end{array}$} \\
\hline Zoning Regulations & $\begin{array}{l}\text { Agricultural land may serve as open } \\
\text { space in cluster developments zo } \\
\text { Protection of farmland is mentioned } \\
\text { as a public purpose of the Planned } \\
\text { Development District zo }\end{array}$ & $\begin{array}{l}\text { Has not promoted land } \\
\text { conservation. } \\
\begin{array}{l}\text { Has not promoted land } \\
\text { conservation }\end{array}\end{array}$ \\
\hline \multicolumn{3}{|l|}{ Site Design } \\
\hline Other & $\begin{array}{l}\text { - Farm, Forest and Open Space } \\
\text { Program }\end{array}$ & \\
\hline Open Space Zoning & $\begin{array}{l}\text { Permitted uses "by right" include: } \\
\text { most recreational uses, government } \\
\text { administrative buildings, libraries and } \\
\text { minor recreation centers, as well as } \\
\text { commercial uses such as driving } \\
\text { ranges and riding stables. zo } \\
\text { Agricultural uses are allowed subject to } \\
\text { performance standards. zo }\end{array}$ & \\
\hline \multicolumn{3}{|l|}{$\begin{array}{l}\text { Open Space } \\
\text { Preservation }\end{array}$} \\
\hline $\begin{array}{l}\text { Residential Cluster } \\
\text { Development }\end{array}$ & $\begin{array}{l}\text { Mandatory cluster for all major } \\
\text { subdivisions in R-3A, R-2A and R-40 } \\
\text { Zoning Districts (40\% of the total } \\
\text { land area must be protected open } \\
\text { space, } 35 \% \text { of which must be suitable } \\
\text { for active recreational purposes; no } \\
\text { more than } 25 \% \text { shall be made } \\
\text { impervious; unbuildable land may } \\
\text { account for a maximum of } 50 \% \text { of } \\
\text { protected open space) zo }\end{array}$ & $\begin{array}{l}\text { The clusters are not too } \\
\text { bad. There is a need for } \\
\text { better site analysis prior } \\
\text { to the lay out of lots. A } \\
\text { BMP would have the } \\
\text { developers come in with } \\
\text { colored contour maps } \\
\text { prior to site drawings. } \\
>\text { Planner uses a GIS } \\
\text { database for site analysis } \\
\text { for all developments } \\
>\text { Planner does a site visit } \\
\text { for all developments. }\end{array}$ \\
\hline Residential Compounds & $\begin{array}{l}\text { Residential Compounds allowed in the } \\
\text { R-3A and R-2A zones zo }\end{array}$ & \\
\hline Large Lot Zoning & - 3-Acre Zoning & \\
\hline
\end{tabular}




\section{Charlestown Municipal Protections}

\begin{tabular}{|l|l|l|}
\hline Issue Area & Municipal Protection Measures & Implementation \\
\hline
\end{tabular}

\begin{tabular}{|c|c|c|}
\hline $\begin{array}{l}\text { Land Preservation } \\
\text { (continued) }\end{array}$ & & \\
\hline $\begin{array}{l}\text { Land Unsuitable for } \\
\text { Development }\end{array}$ & $\begin{array}{l}\text { - Land Unsuitable for Development-- } \\
\text { "Constraints to Development" ( shall } \\
\text { be deducted from the developable } \\
\text { acreage of the parcel--resource areas } \\
\text { subject to protective setback distance } \\
\text { such as but not limited to, wetlands; } \\
\text { areas subject to storm flow or } \\
\text { flooding; hydric soils and inter-tidal } \\
\text { salt marshes; land located in any V } \\
\text { zones or floodways; any area of the } \\
\text { track proposed to be developed equal } \\
\text { to the area of any street and/or utility } \\
\text { rights-of-way; any unique sites having } \\
\text { historical, archeological values or } \\
\text { protected species of flora or fauna; any } \\
\text { other lands which if developed would } \\
\text { cause a threat to public health, or } \\
\text { result in irreparable public harm, or } \\
\text { loss of irreplaceable resources; any } \\
\text { area of ledge and/or rock outcrops } \\
\text { at/or within four feet of the land } \\
\text { surface, any area where slopes exceed } \\
\text { fifteen percent) }\end{array}$ & $\begin{array}{l}\text { Strictly adhered to } \\
\text { Developer required to } \\
\text { provide a certified letter } \\
\text { from DEM's Natural } \\
\text { Heritage Program } \\
>\quad \text { The Town has } \\
\text { "constraints maps" }\end{array}$ \\
\hline $\begin{array}{l}\text { Dedication of Land for } \\
\text { Public Purposes }\end{array}$ & $\begin{array}{l}\text { Recreation Facilities and Open Space } \\
\text { Dedication (land dedication, payment } \\
\text { in lieu or both are required; amount of } \\
\text { land to be dedicated is } \\
.01 \text { acres/person) }\end{array}$ & \\
\hline \multicolumn{3}{|l|}{ Site Design } \\
\hline Other & $\begin{array}{l}\text { - South County Conservancy } \\
\text { - The town has a grant proposal in to } \\
\text { DEM for an Open Space Grant. }\end{array}$ & $\begin{array}{l}\text { The Planning } \\
\text { Commission is working } \\
\text { on an Open Space Plan }\end{array}$ \\
\hline
\end{tabular}




\section{Charlestown Municipal Protections}

\begin{tabular}{|l|l|l|}
\hline Issue Area & Municipal Protection Measures & Implementation \\
\hline
\end{tabular}

\begin{tabular}{|c|c|c|}
\hline $\begin{array}{l}\text { Natural Resource } \\
\text { Protection }\end{array}$ & & \\
\hline \multicolumn{3}{|l|}{ Wetlands } \\
\hline $\begin{array}{l}\text { Erosion and Sediment } \\
\text { Control Plan }\end{array}$ & $\begin{array}{l}\text { Erosion and Sediment Control Plan } \\
\text { (required for all major applications as } \\
\text { well as all land development within } \\
200 \text { feet of any waterbody, } \\
\text { watercourse, wetland or coastal } \\
\text { feature) }\end{array}$ & $\begin{array}{l}\text { Strictly implemented and } \\
\text { monitored } \\
\text { Major subdivision sites } \\
\text { are monitored by the } \\
\text { Public Works Director } \\
\text { Commercial land } \\
\text { developments are } \\
\text { monitored by the } \\
\text { Building Inspector. } \\
\text { The town has a small } \\
\text { public works department } \\
\text { that is highly invested in } \\
\text { ensuring good erosion } \\
\text { and sediment control. }\end{array}$ \\
\hline $\begin{array}{l}\text { Land Unsuitable for } \\
\text { Development }\end{array}$ & $\begin{array}{l}\text { - Wetlands are defined as "land } \\
\text { unsuitable for development" }\end{array}$ & $>$ Strictly adhered to \\
\hline $\begin{array}{l}\text { Environmental } \\
\text { Analysis/Impact } \\
\text { Statement }\end{array}$ & $\begin{array}{l}\text { Environmental Analysis (for all major } \\
\text { applications as well as land } \\
\text { development occurring on sites with } \\
\text { wetlands or high watertables) }\end{array}$ & $\begin{array}{l}\text { Strictly adhered to } \\
\text { There is townwide } \\
\text { support for water quality } \\
\text { protection. }\end{array}$ \\
\hline Site Design & $\begin{array}{l}\text { - Physical Design and Public } \\
\text { Improvement Standards (existing } \\
\text { features such as...wetlands shall be } \\
\text { preserved in the design of the } \\
\text { subdivision) }\end{array}$ & $\begin{array}{l}\text { Strictly adhered to } \\
\text { Implemented through } \\
\text { mandatory cluster } \\
\text { provisions for major } \\
\text { subdivisions } \\
\end{array}$ \\
\hline Site Plan Review & $\begin{array}{l}\text { - Site Plan Review, Standards (sites to } \\
\text { be developed shall alter the natural } \\
\text { topography as minimally as possible } \\
\text { and shall avoid 'Constraints to } \\
\text { Development') }\end{array}$ & $\begin{array}{l}\text { Strictly adhered to } \\
\text { Identified through GIS, } \\
\text { site analysis and an EIS }\end{array}$ \\
\hline Performance Standards & $\begin{array}{l}\text { - Performance Standards, Water bodies } \\
\text { (No facility designed to leach liquid } \\
\text { wastes into the soil shall be located } \\
\text { within } 100 \text { feet of a boundary of a } \\
\text { freshwater or coastal wetland) zo }\end{array}$ & $\begin{array}{l}\text { Zoning Board of Review } \\
\text { is unlikely to allow a } \\
\text { variance. }\end{array}$ \\
\hline Otber & - Wastewater Management District & $\begin{array}{l}\text { The town has a } \\
\text { Wastewater Management } \\
\text { Commission. }\end{array}$ \\
\hline
\end{tabular}




\section{Charlestown Municipal Protections}

\begin{tabular}{|l|l|l|}
\hline Issue Area & Municipal Protection Measures & Implementation \\
\hline
\end{tabular}

\begin{tabular}{|c|c|c|}
\hline $\begin{array}{l}\text { Watercourses/ } \\
\text { Surface Waters }\end{array}$ & & \\
\hline $\begin{array}{l}\text { Erosion and Sediment } \\
\text { Control Plan }\end{array}$ & $\begin{array}{l}\text { Erosion and Sediment Control Plan } \\
\text { (for all major applications as well as all } \\
\text { land development within } 200 \text { feet of } \\
\text { any waterbody, watercourse, wetland } \\
\text { or coastal feature) }\end{array}$ & $\begin{array}{l}\text { Strictly adhered to and } \\
\text { monitored for all major } \\
\text { subdivisions and land } \\
\text { developments. }\end{array}$ \\
\hline Protection District & $\begin{array}{l}\text { Flood Hazard Areas (Development } \\
\text { that alters water-carrying capacity is } \\
\text { prohibited pursuant to the flood } \\
\text { hazard overlay district) zo }\end{array}$ & $D$ Strictly adhered to \\
\hline $\begin{array}{l}\text { Environmental } \\
\text { Analysis/Impact } \\
\text { Statement }\end{array}$ & $\begin{array}{l}\text { Environmental Analysis (required } \\
\text { where Planning Commission finds a } \\
\text { reasonable cause that the proposed } \\
\text { development will have a negative } \\
\text { environmental impact on the natural } \\
\text { or manmade environment on the } \\
\text { property or upon nearby properties or } \\
\text { natural systems) }\end{array}$ & $\begin{array}{l}\text { Required for all major } \\
\text { subdivisions and land } \\
\text { developments }\end{array}$ \\
\hline \multicolumn{3}{|l|}{ Site Design } \\
\hline Site Plan Review & $\begin{array}{l}\text { Site Plan Review, Standards--required } \\
\text { for all nonresidential activities } \\
\text { (measures shall conform to the } \\
\text { minimum standards of the } 1993 \text { State } \\
\text { of RI Stormwater Manual) zo }\end{array}$ & $\begin{array}{ll} & \text { Strictly adhered to } \\
\text { Public Works Director } \\
\text { Monitors stormwater } \\
\text { management provisions }\end{array}$ \\
\hline Performance Standards & $\begin{array}{l}\text { Performance Standards, Water bodies } \\
\text { (No facility designed to leach liquid wastes } \\
\text { into the soil shall be located in that area of } \\
\text { land a) within } 100 \text { feet of the edge of any } \\
\text { intermittent stream; b) within } 200 \text { feet of } \\
\text { the edge of any flowing body of water } \\
\text { having a width of } 10 \text { feet or more; } c \text { ) } \\
\text { within } 100 \text { feet of the edge of any lowing } \\
\text { body of water having a width of } 10 \text { feet or } \\
\text { less) except by the granting of a special use } \\
\text { permit zo }\end{array}$ & $\begin{array}{l}\text { Strictly adhered to. } \\
\text { Planning Commission has } \\
\text { authority to increase } \\
\text { criteria }\end{array}$ \\
\hline $\begin{array}{l}\text { Groundwater/ } \\
\text { Recharge Areas }\end{array}$ & · & \\
\hline Protection District & $\begin{array}{l}\text { - Groundwater Protection Overlay } \\
\text { District (site plan review and an } \\
\text { environmental impact statement are } \\
\text { required) zo }\end{array}$ & $\begin{array}{ll}\text { Strictly adhered to } \\
\text { (It is a model ordinance) }\end{array}$ \\
\hline $\begin{array}{l}\text { Environmental } \\
\text { Analysis/Impact } \\
\text { Statement }\end{array}$ & $\begin{array}{l}\text { Environmental Analysis (required for } \\
\text { all land developments in areas } \\
\text { designated by RIDEM as a } \\
\text { groundwater reservoir, groundwater } \\
\text { recharge area, or wellhead protection } \\
\text { area) }\end{array}$ & Strictly adhered to \\
\hline
\end{tabular}




\section{Charlestown Municipal Protections}

\begin{tabular}{|l|l|l|}
\hline Issue Area & Municipal Protection Measures & Implementation \\
\hline
\end{tabular}

\begin{tabular}{|c|c|c|}
\hline \multicolumn{3}{|l|}{$\begin{array}{l}\text { Groundwater/ } \\
\text { Recharge Areas } \\
\text { (Continued) }\end{array}$} \\
\hline Site Design & $\begin{array}{l}\text { - } \begin{array}{l}\text { Site Design Standards (development } \\
\text { shall be laid out to avoid adversely } \\
\text { affecting groundwater and aquifer } \\
\text { recharge...) }\end{array} \\
\end{array}$ & $D$ Strictly adhered to \\
\hline Site Plan Review & $\begin{array}{l}\text { Site Plan Review, Standards, } \\
\text { Environmental Constraints--required } \\
\text { for all nonresidential development } \\
\text { (sites to be developed shall avoid areas } \\
\text { of high groundwater, seasonal or } \\
\text { permanent) zo }\end{array}$ & Strictly adhered to \\
\hline Other & $\begin{array}{ll}\text { - Wellhead Protection } \\
\text { - Wastewater Management District }\end{array}$ & \\
\hline \multicolumn{3}{|l|}{ Floodplains } \\
\hline Protection District & $\begin{array}{l}\text { Flood Hazard Areas (Development } \\
\text { that alters water-carrying capacity is } \\
\text { prohibited pursuant to the flood } \\
\text { hazard overlay district) zo }\end{array}$ & $\begin{array}{l}\text { Well implemented --the } \\
\text { Building Inspector has a } \\
\text { good background. }\end{array}$ \\
\hline $\begin{array}{l}\text { Land Unsuitable for } \\
\text { Development }\end{array}$ & $\begin{array}{l}\text { Areas subject to storm flow or } \\
\text { flooding defined as "land unsuitable } \\
\text { for development" }\end{array}$ & Strictly adhered to \\
\hline $\begin{array}{l}\text { Environmental } \\
\text { Analysis/Impact } \\
\text { Statement }\end{array}$ & $\begin{array}{l}\text { Environmental Analysis (required for } \\
\text { all developments partially or wholly } \\
\text { located in an area designated as a } \\
\text { floodway, V zone or } 100 \text { year } \\
\text { floodplain) }\end{array}$ & Strictly adhered to \\
\hline \multicolumn{3}{|l|}{ Site Design } \\
\hline Site Plan Review & $\begin{array}{l}\text { Site Plan Review, Standards--required } \\
\text { for all nonresidential developments } \\
\text { (sites to be developed shall alter the } \\
\text { natural topography as minimally as } \\
\text { possible and shall avoid 'Constraints to } \\
\text { Development') }\end{array}$ & $>$ Adhered to \\
\hline Performance Standards & $\begin{array}{l}\text { Performance Standards, Water bodies } \\
\text { (No facility designed to leach liquid } \\
\text { wastes into the soil shall be located in } \\
\text { that area of land defined as a } 100 \text { year } \\
\text { flood hazard boundary Zone A on the } \\
\text { official Flood Insurance Rate Maps) } \\
\text { zo }\end{array}$ & Adhered to \\
\hline Other & - 1997 Hazard Mitigation Plan & $\begin{array}{l}1997 \text { Hazard Mitigation } \\
\text { Plan has a Recovery Plan } \\
\text { stipulation which compels } \\
\text { private owners to rebuild } \\
\text { away from flood zones }\end{array}$ \\
\hline
\end{tabular}




\section{Charlestown Municipal Protections}

\begin{tabular}{|l|l|l|}
\hline Issue Area & Municipal Protection Measures & Implementation \\
\hline
\end{tabular}

\begin{tabular}{|c|c|c|c|}
\hline Topography & & & \\
\hline $\begin{array}{l}\text { Erosion and Sediment } \\
\text { Control Plan }\end{array}$ & $\begin{array}{l}\text { Erosion and Sediment Control Plan } \\
\text { (for all major subdivisions and land } \\
\text { development and for all development } \\
\text { where slope exceeds } 15 \% \text { ) }\end{array}$ & $D$ & $\begin{array}{l}\text { Strictly implemented and } \\
\text { monitored }\end{array}$ \\
\hline $\begin{array}{l}\text { Land Unsuitable for } \\
\text { Development }\end{array}$ & $\begin{array}{l}\text { Land Unsuitable for Development } \\
\text { (any area of ledge and/or rock } \\
\text { outcrops at/or within four feet of the } \\
\text { land surface; any area where slopes } \\
\text { exceed } 15 \% \text { ) }\end{array}$ & $>$ & Adhered to \\
\hline $\begin{array}{l}\text { Environmental } \\
\text { Analysis/Impact } \\
\text { Statement }\end{array}$ & $\begin{array}{l}\text { Environmental Analysis (required for } \\
\text { all major subdivisions and land } \\
\text { developments and where slope } \\
\text { exceeds } 15 \% \text { on greater than } 25 \% \text { of } \\
\text { the development) }\end{array}$ & $>$ & Adhered to \\
\hline Site Design & $\begin{array}{l}\text { Design Standards (Development shall } \\
\text { minimize adverse effects upon the } \\
\text { natural or existing topography and } \\
\text { soils conditions to minimize the } \\
\text { potential for erosion; grading and } \\
\text { other site preparation shall be kept to } \\
\text { an absolute minimum; excess cutting, } \\
\text { filling or stripping vegetation shall not } \\
\text { be permitted) }\end{array}$ & & $\begin{array}{l}\text { Implemented through } \\
\text { mandatory cluster for } \\
\text { major subdivisions } \\
\text { Problem with sites under } \\
5 \text { acres not regulated by } \\
\text { DEM for clearing } \\
\text { permits. Owners will strip } \\
\text { site prior to development } \\
\text { application. }\end{array}$ \\
\hline Site Plan Review & $\begin{array}{l}\text { Site Plan Review, Standards, } \\
\text { Environmental Constraints--required } \\
\text { for all nonresidential activities } \\
\text { (development shall avoid areas of high } \\
\text { groundwater, soils with excessively } \\
\text { slow or fast percolation, ridgelines) }\end{array}$ & & Adhered to \\
\hline
\end{tabular}




\section{Charlestown Municipal Protections}

\begin{tabular}{|l|l|l|}
\hline Issue Area & Municipal Protection Measures & Implementation \\
\hline
\end{tabular}

\begin{tabular}{|c|c|c|}
\hline $\begin{array}{l}\text { Rare Species/ } \\
\text { Critical Habitat }\end{array}$ & & \\
\hline $\begin{array}{l}\text { Land Unsuitable for } \\
\text { Development }\end{array}$ & - Land Unsuitable for Development & $\begin{array}{l}\text { Strictly implemented. } \\
\text { Developer is required to } \\
\text { obtain a certified letter } \\
\text { from the Natural } \\
\text { Heritage Program }\end{array}$ \\
\hline $\begin{array}{l}\text { Environmental } \\
\text { Analysis/ Impact } \\
\text { Statement }\end{array}$ & - Environmental Analysis (required) & Strictly adhered to \\
\hline Site Design & $\begin{array}{l}\text { Physical Design and Public } \\
\text { Improvement Standards (existing } \\
\text { features such as woodlands, wetlands, } \\
\text { cemeteries, wildflower sites, } \\
\text { archeological sites, areas of unique } \\
\text { botanical interest and similar } \\
\text { irreplaceable assets, shall be preserved } \\
\text { in the design of the subdivision) }\end{array}$ & $\begin{array}{l}\text { Implemented through } \\
\text { cluster design and site } \\
\text { analysis }\end{array}$ \\
\hline Site Plan Review & $\begin{array}{l}\text { Site Plan Review, Standards, Historic } \\
\text { and Archaeological Areas--required for } \\
\text { all nonresidential developments (There } \\
\text { shall not be any adverse effect on the } \\
\text { scenic or natural beauty of the areas. } \\
\text { Historical sites, specimen vegetation } \\
\text { and rare and irreplaceable natural areas } \\
\text { shall not be disturbed) }\end{array}$ & Adhered to \\
\hline Otber & $\begin{array}{l}\text { - Land acquisition through South } \\
\text { County Conservancy }\end{array}$ & \\
\hline
\end{tabular}




\section{Charlestown Municipal Protections}

\begin{tabular}{|l|l|l|}
\hline Issue Area & Municipal Protection Measures & Implementation \\
\hline
\end{tabular}

\begin{tabular}{|c|c|c|}
\hline Coastal Features & & \\
\hline $\begin{array}{l}\text { Erosion and Sediment } \\
\text { Control Plan }\end{array}$ & $\begin{array}{l}\text { Erosion and Sediment Control Plan } \\
\text { (for all major subdivisions and land } \\
\text { developments as well as for all land } \\
\text { development within } 200 \text { feet of any } \\
\text { waterbody, watercourse, wetland or } \\
\text { coastal feature) }\end{array}$ & Strictly adhered to \\
\hline Protection District & $\begin{array}{l}\text { In Zones VI-V-30, the alteration of } \\
\text { sand dunes and/or undeveloped } \\
\text { barrier beaches is prohibited for any } \\
\text { purpose zo }\end{array}$ & $\begin{array}{l}\text { She would like to see all } \\
\text { development on barrier } \\
\text { beaches prohibited } \\
1997 \text { Hazard Mitigation } \\
\text { Plan has a Recovery Plan } \\
\text { stipulation which compels } \\
\text { private owners to rebuild } \\
\text { away from flood zones } \\
\end{array}$ \\
\hline $\begin{array}{l}\text { Land Unsuitable for } \\
\text { Development }\end{array}$ & $\begin{array}{l}\text { Intertidal salt marshes considered } \\
\text { "land unsuitable for development" }\end{array}$ & Strictly adhered to \\
\hline Setbacks & $\begin{array}{l}\text { All new construction must be } \\
\text { landward of the reach of mean high } \\
\text { tide zo }\end{array}$ & Strictly adhered to \\
\hline $\begin{array}{l}\text { Environmental } \\
\text { Analysis/Impact } \\
\text { Statement }\end{array}$ & $\begin{array}{l}\text { Environmental Analysis (for all major } \\
\text { subdivisions and land developments as } \\
\text { well as for land that is entirely or } \\
\text { partially located in an area subject to } \\
\text { review under the RI CRMC Special } \\
\text { Area Management Plan) }\end{array}$ & $>$ Strictly adhered to \\
\hline Site Plan Review & $\begin{array}{l}\text { Site Plan Review, Environmental } \\
\text { Considerations (sites to be developed } \\
\text { shall avoid areas with "Constraints to } \\
\text { Development") zo }\end{array}$ & $>$ Strictly adhered to \\
\hline Performance Standards & $\begin{array}{l}\text { Performance Standards, Water bodies } \\
\text { (No facility designed to leach liquid } \\
\text { wastes into the soil shall be located } \\
\text { within } 100 \text { feet of a boundary of a } \\
\text { freshwater or coastal wetland) zo }\end{array}$ & $\begin{array}{l}\text { Performance Standards } \\
\text { strictly enforced }\end{array}$ \\
\hline
\end{tabular}




\section{TOWN OF COVENTRY PROFILE}

\section{Summary}

The Town of Coventry is actively working to increase its capacity to protect and preserve its natural resources and remaining open spaces. These issues have become priority concerns under current suburban growth pressures. The planning department has recently finished updating its 1992 comprehensive plan, and is presently working to adopt and implement a number of the plan's objectives for land conservation and natural resource protection. The town council and the town manager are strongly in support of strengthening conservation measures, and both have recently championed several natural resource protection initiatives.

Coventry's land conservation and natural resource protection efforts are primarily focused on preserving active farmland, rural character, and water resources. The Town is in the process of strengthening its subdivision and zoning regulations to encourage more environmentally sensitive development. The town council has requested the adoption of a watershed protection district. The new ordinance will be fashioned after a "model ordinance" from the Scituate Reservoir Protection Project. The town manager and the planning department have just completed work on a new tree ordinance to prohibit excessive clearing of land under development. The Town already promotes flexibility in requirements for frontage setbacks, road widths and public rights-of-way to help preserve rural character. New performance standards and septic system setback requirements from water bodies are also in the works. 


\section{Planning Department}

The Coventry Planning Department is comprised of two full-time

professionals--the new town planner (with a background in landscape

architecture and environmental consulting) and the building inspector. A halftime GIS technician is also on staff. To augment in-house planning capacity, the department maintains a number of unique working relationships with outside agency groups. For instance, the Town contracts with the Southern Rhode Island Conservation District for assistance in evaluating and monitoring erosion and sedimentation control plans. It also contracts with the Rhode Island Resource Conservation and Development Council, Inc. and Environmental Design, Inc. to prepare environmental analysis reports (Environmental Review Team Reports) during the development review process for all major subdivisions and land developments, as well as for any development occurring in environmentally sensitive areas. Fees for both services are charged to developers.

The town planner and the building inspector maintain a strong working relationship. The town planner feels confident that there is broad consensus among town officials on the need to increase the Town's capacity for land conservation and natural resource protection. Aside from actively supporting the adoption of new environmental regulations, the town council and town manager also supported the purchase of deed based, digitized parcel maps for the town. Although in-house GIS capacity is somewhat limited at present, the Environmental Review Team Reports (ERT) provide a great deal of information on the environmental constraints of parcels under review. The planning commission seems to be very diligent in their use of this service.

According to both the town planner and the building inspector, the department's principle capacity limitations are due to lack of staffing and resources. Any assistance would be welcome. The town planner is already overextended. In addition to his full-time job as town planner, he also works 
with the conservation commission and the new land trust to provide them with much needed technical support and expertise.

\section{Comprehensive Plan Objectives}

The town planner is aggressively working to adopt and implement comprehensive plan objectives. The natural resource element of the plan is primarily focused on water quality protection and the preservation of rural lands. The new land trust will take responsibility for furthering many of the Town's land conservation objectives. New subdivision and zoning regulations are incorporating important comprehensive plan objectives such as higher standards for water resource protection. The new watershed protection district was a principal objective of the plan.

Coventry is the largest municipality in the state. Its land area covers both an old urban core and large tracts of agricultural and forested areas. There is a clear division in land use/land cover between the eastern and the western portions of town. Suburban growth pressures in the western portion of the Town have prompted town officials to reassess subdivision regulations. The Town is considering refining its regulations to better preserve the rural areas of town. For example, the Town may amend its residential cluster development ordinance to require a higher percentage of open space in the western portion of town.

Coventry is the only town in the study area that directly links provisions in its subdivision and land development regulations to the comprehensive plan. The Town's subdivision and land development regulations require that an Environmental Review Team Report be conducted if all or part of the property is identified in the Natural and Cultural Resources Element of the Comprehensive Plan. 


\section{Site Analysis}

The Town is in the process of increasing its in-house GIS capacity. At present, it is not able to access parcel-based information. It appears that the planning department and planning commission rely heavily on onsite analysis. The ERT Report, required for most developments in town, are prepared by staff from agencies such as Rhode Island Department of Environmental Management and USDA Natural Resource Conservation Service. The report provides not only detailed site information, but also evaluative commentary on development plan submittals. For example, the ERT Report includes field assessments of mapped data, such as wetlands boundaries and test holes for groundwater submitted by developers.

The town planner, the conservation commission and the planning commission are all involved in conducting onsite environmental analysis. In addition, developers are required to submit a formal site analysis, a written or graphic analysis describing the potential impact of the development on environmentally sensitive areas such as wetlands, areas with steep slopes, and agricultural lands. The planning commission promotes clustered development wherever appropriate, which greatly enhances its ability to guide development away from environmentally sensitive areas.

\section{Zoning and Subdivision Regulations}

\section{Zoning Ordinances}

- Farmland Zoning-none

- Residential Cluster Development - Coventry is the only town in the study area that provides a density bonus and other incentives in the cluster ordinance for the preservation of agricultural land. A density bonus of up to 20 percent is also provided for all cluster developments where 50 percent of the parcel is preserved as open space. Coventry has a unique provision in the cluster ordinance stating that: "land which has been environmentally damaged prior to final approval of the development...as a result of soil and earth removal operations, harvesting of trees or other natural features or refuse disposal or other causes shall not be accepted 
as common open space unless and until the land is restored to a condition which the Planning Commission determines to be reasonable..."

- Large Lot Residential Zoning--A large portion of Coventry's remaining open lands are zoned as either 5 acre, 3 acre or 2 acre lot sizes.

- Environmental Protection Overlay Districts- none

- Site Plan Review-The Town's Site Plan Review Ordinance includes specific provisions for the implementation of "best management practices" for erosion control, stormwater management and wastewater disposal and landscaping. The ordinance includes detailed environmental considerations and protection measures.

- Performance Standards-The Town zoning ordinance includes "Performance Standards for Sewage and Water-borne Wastes" and a "Hazardous Waste Management Facilities, Siting Restrictions" regulation.

\section{Subdivision and Land Development Regulations}

Coventry's subdivision regulations are both detailed and comprehensive in comparison to other towns in the study area. Large-lot residential districts of 5 acre, 3 acre and 2 acre provide extra flexibility in ensuring environmentally sensitive site design. Mandatory site analysis for all development in environmentally sensitive areas also provides extra assurance of environmental considerations in site design.

- Land Unsuitable for Development-Shall be subtracted from the total parcel in order to determine the maximum number of dwelling units-wetlands, including perimeter wetlands; land located within Zone A on a FEMA Map; street allowance; all existing public and private easements; land containing steep slopes in excess of $20 \%$ within any 10 feet interval on the contour drawing.

- Environmental Analysis--The Town's "Environmental Review Team Report" requirements provide a unique way to augment local planning capacity while at the same time assuring a high level of environmental analysis during the development process.

- Erosion and Sediment Control--The Town requires an "erosion and sediment control plan" for all development in town. The Town contracts with the Southern Rhode Island Conservation District for assistance in evaluating and monitoring plans. As a landscape architect, the town planner is committed to the use of "best management practices" and diligent monitoring of sites.

- Site Design Standards--Coventry's site design standards include a fairly comprehensive list of areas that should be preserved as open space in the design of the site. The site design regulations also include site analysis requirements-a written or graphic analysis describing the potential impact of the development on environmentally sensitive areas, further ensures environmental considerations in site design. 


\begin{tabular}{|l|l|l|}
\hline Issue Area & $\begin{array}{l}\text { Comprehensive Planning } \\
\text { Objective }\end{array}$ & Implementation \\
\hline
\end{tabular}

\begin{tabular}{|c|c|c|}
\hline $\begin{array}{l}\text { Land } \\
\text { Conservation }\end{array}$ & & \\
\hline \multicolumn{3}{|l|}{$\begin{array}{l}\text { Farmland } \\
\text { Preservation }\end{array}$} \\
\hline & $\begin{array}{l}\text { "Formulate and adopt an } \\
\text { Agricultural Protection } \\
\text { Overlay District (LU } \\
\text { Implementation, E.3)." }\end{array}$ & Not implemented \\
\hline & $\begin{array}{l}\text { "Establish a local Farm } \\
\text { Advisory Board that } \\
\text { includes farmers, farm } \\
\text { property owners, } \\
\text { agricultural-related } \\
\text { businesspersons, the local } \\
\text { county extension service } \\
\text { agent and the local SCS } \\
\text { agent (Natural \& Cultural } \\
\text { Resources Plan Element, } \\
\text { D.16)." }\end{array}$ & Not implemented \\
\hline \multicolumn{3}{|l|}{$\begin{array}{l}\text { Open Space } \\
\text { Zoning }\end{array}$} \\
\hline \multicolumn{3}{|l|}{$\begin{array}{l}\text { Open Space } \\
\text { Preservation }\end{array}$} \\
\hline & $\begin{array}{l}\text { "Methods of easements, } \\
\text { zoning, and subdivision } \\
\text { controls will be used as } \\
\text { altematives for obtaining } \\
\text { and preserving recreation, } \\
\text { conservation and open } \\
\text { space when out-right } \\
\text { purchase is not feasible } \\
\text { (Open Space and Recreation } \\
\text { Policies, D.7-2)." }\end{array}$ & $\begin{array}{ll} & \text { Cluster provisions } \\
& \text { Dedication of Land for Public Purposes }\end{array}$ \\
\hline & $\begin{array}{l}\text { "Aggressively develop a } \\
\text { prioritized inventory of } \\
\text { open space parcels for } \\
\text { eventual acquisition/control } \\
\text { as permanent open space } \\
\text { (Natural \& Cultural } \\
\text { Resources Implementation, } \\
\text { E.20)." } \\
\end{array}$ & $>$ New Land Trust \\
\hline & $\begin{array}{l}\text { "Establish a program to } \\
\text { permanently acquire and/or } \\
\text { ensure the conservation of } \\
\text { priority open space parcels" }\end{array}$ & $D$ New Land Trust \\
\hline
\end{tabular}


Coventry Comprehensive Plan Matrix

\begin{tabular}{|l|l|l|}
\hline Issue Area & Comprehensive Planning & Implementation
\end{tabular}

Objective

\begin{tabular}{|l|l|l|}
\hline $\begin{array}{l}\text { Natural } \\
\text { Resource } \\
\text { Protection }\end{array}$ & \\
\hline Wetlands & "Adopt a town policy that \\
& $\begin{array}{l}\text { removes wetlands areas from } \\
\text { the density calculations for } \\
\text { residential subdivisions } \\
\text { (Natural \& Cultural Resources } \\
\text { Implementation, E.19)" }\end{array}$ & $>$ Adopted \\
\hline & $\begin{array}{l}\text { "Where possible, the town or } \\
\text { non-profit conservancy groups } \\
\text { should purchase wetlands for } \\
\text { protection (Natural and } \\
\text { Cultural Resources Plan } \\
\text { Element, D.16)." }\end{array}$ & \\
\hline & $\begin{array}{l}\text { "As a minimum, adhere to and } \\
\text { enforce existing RIDEM } \\
\text { wetlands setback regulations } \\
\text { after appropriate study of a } \\
\text { 150' natural buffer-to address } \\
\text { existing regulatory deficiencies, } \\
\text { and modify standards to } \\
\text { protect environmental quality } \\
\text { (Natural \& Cultural Resources } \\
\text { Implementation, E.19)." }\end{array}$ \\
\hline & \\
\hline
\end{tabular}




\section{\begin{tabular}{|l|l|l|}
\hline Issue Area & Comprehensive Planning & Implementation
\end{tabular}}

Objective

\begin{tabular}{|c|c|c|}
\hline $\begin{array}{l}\text { Watercourses/ } \\
\text { Surface Waters }\end{array}$ & & \\
\hline & $\begin{array}{l}\text { "Prepare Water Quality } \\
\text { Protection Plan--to protect the } \\
\text { town's groundwater and } \\
\text { surface water (Community } \\
\text { Services and Facilities } \\
\text { Implementation, E. 17)." }\end{array}$ & $\begin{array}{l}\text { Uses Environmental Data Center Maps } \\
>\text { Wellhead Protection Zone }\end{array}$ \\
\hline & $\begin{array}{l}\text { "Formulate and adopt a } \\
\text { Watershed Protection Overlay } \\
\text { District--to establish specific } \\
\text { watershed growth management } \\
\text { controls to minimize impacts } \\
\text { on water quality, and protect } \\
\text { groundwater and wetlands } \\
\text { resources (LU Implementation, } \\
\text { E.3)." }\end{array}$ & $\begin{array}{l}\text { Presently working on (using Scituate } \\
\text { Ordinance as a model) }\end{array}$ \\
\hline & $\begin{array}{l}\text { Masterplan the Riverfront Trail } \\
\text { System and related } \\
\text { neighborhood facilities--to } \\
\text { ensure protection of and } \\
\text { availability to the public of a } \\
\text { notable natural community } \\
\text { amenity, namely, approximately } \\
\text { five miles of the riverfront of } \\
\text { the south branch of the } \\
\text { Pawtuxet River (Open Space \& } \\
\text { Recreation, E.24)." }\end{array}$ & $\begin{array}{l}\text { The town is currently working with the } \\
\text { Pawtuxet River Authority to digitize parcel } \\
\text { boundaries along the river }\end{array}$ \\
\hline & $\begin{array}{l}\text { - Adopt a Soil and } \\
\text { Sedimentation Ordinance to } \\
\text { reduce degradation of water } \\
\text { resources }\end{array}$ & $>$ Adopted \\
\hline & $\begin{array}{l}\text { "Adopt a Stormwater } \\
\text { Management Ordinance which } \\
\text { would establish design and } \\
\text { performance standards... and } \\
\text { require new developments to } \\
\text { use the Best Management } \\
\text { Practices to reduce stormwater } \\
\text { runoff and non-point source } \\
\text { pollution (Natural \& Cultural } \\
\text { Resources Plan Element, } \\
\text { D.13)." }\end{array}$ & $\begin{array}{l}\text { Did not adopt a stand-alone ordinance. } \\
\text { Stormwater management plans are required } \\
\text { for all major subdivisions and land } \\
\text { developments }\end{array}$ \\
\hline & $\begin{array}{l}\text { "Implement Wastewater } \\
\text { Management Districts } \\
\text { (Community Services and } \\
\text { Facilities Implementation, E.1- } \\
\text { 16)." }\end{array}$ & $>$ Not Adopted \\
\hline
\end{tabular}


Coventry Comprehensive Plan Matrix

\begin{tabular}{|l|l|l|}
\hline Issue Area & $\begin{array}{l}\text { Comprehensive Planning } \\
\text { Objective }\end{array}$ & Implementation \\
\hline
\end{tabular}

\begin{tabular}{|c|c|c|}
\hline $\begin{array}{l}\text { Groundwater/ } \\
\text { Recharge } \\
\text { Areas }\end{array}$ & - & \\
\hline & $\begin{array}{l}\text { "Prepare Water Quality } \\
\text { Protection Plan--to protect } \\
\text { the town's groundwater and } \\
\text { surface water (Community } \\
\text { Services and Facilities } \\
\text { Implementation, E. 17)." }\end{array}$ & $\begin{array}{l}>\text { Uses Environmental Data Center Maps } \\
>\text { Well Head Protection Zone }\end{array}$ \\
\hline & $\begin{array}{l}\text { "Conduct a town-wide } \\
\text { point and non-point source } \\
\text { pollution study" (Natural \& } \\
\text { Cultural Resources } \\
\text { Implementation, E.19)." }\end{array}$ & $\begin{array}{l}\text { Would like to use GPS to catalogue all out- } \\
\text { falls in the town. }\end{array}$ \\
\hline & $\begin{array}{l}\text { "Formulate and adopt a Town } \\
\text { Environmental Policy } \\
\text { Statement in regard to } \\
\text { groundwater; wellhead } \\
\text { protection and wetlands } \\
\text { conservation protection-- } \\
\text { (Natural \& Cullural Resources } \\
\text { Implementation, E.18)." } \\
\end{array}$ & Not Adopted \\
\hline & $\begin{array}{l}\text { "Formulate and adopt a } \\
\text { Watershed Protection Overlay } \\
\text { District--to establish specific } \\
\text { watershed growth management } \\
\text { controls to minimize impacts } \\
\text { on water quality, and protect } \\
\text { groundwater and wetlands } \\
\text { resources (LU Implementation, } \\
\text { E.3)." } \\
\end{array}$ & $\begin{array}{l}\text { Presently working on (using Scituate } \\
\text { Ordinance as a model) }\end{array}$ \\
\hline Floodplains & & \\
\hline $\begin{array}{l}\text { Coastal } \\
\text { Features }\end{array}$ & & \\
\hline Topography & & \\
\hline
\end{tabular}




\begin{tabular}{|l|l|l|}
\hline Issue Area & $\begin{array}{l}\text { Comprehensive Planning } \\
\text { Objective }\end{array}$ & Implementation \\
\hline
\end{tabular}

\begin{tabular}{|c|c|c|}
\hline \multicolumn{3}{|l|}{$\begin{array}{l}\text { Rare Species/ } \\
\text { Critical } \\
\text { Habitat }\end{array}$} \\
\hline & $\begin{array}{l}\text { "The town should require the } \\
\text { mapping of vegetative features } \\
\text { in site plan and subdivision } \\
\text { review (Natural \& Cultural } \\
\text { Resources Plan Element, } \\
\text { D.16)." }\end{array}$ & Adopted in Site Analysis requirements \\
\hline & $\begin{array}{l}\text { "The use of innovative land } \\
\text { planning techniques will } \\
\text { increase the potential for } \\
\text { wildlife protection in the town } \\
\text { of Coventry by allowing } \\
\text { flexibility in site design and } \\
\text { conservation of natural } \\
\text { resources (Natural \& Cultural } \\
\text { Resources Plan Element, } \\
\text { D.18)." }\end{array}$ & Adopted Cluster provisions \\
\hline & $\begin{array}{l}\text { "The recommended strategies } \\
\text { to protect water resources, } \\
\text { vegetation and other } \\
\text { conservation strategies in the } \\
\text { Natural and Cultural Resources } \\
\text { Plan element will also protect } \\
\text { wildlife through protection of } \\
\text { habitat (Natural \& Cultural } \\
\text { Resources Plan Element, } \\
\text { D.18)." }\end{array}$ & Adopted \\
\hline \multicolumn{3}{|l|}{$\begin{array}{l}\text { Trees/ } \\
\text { Woodlands }\end{array}$} \\
\hline \multicolumn{3}{|l|}{$\begin{array}{l}\text { Cultural and } \\
\text { Historic } \\
\text { Resources }\end{array}$} \\
\hline \multicolumn{3}{|l|}{$\begin{array}{l}\text { Village/Rural } \\
\text { Character }\end{array}$} \\
\hline & $\begin{array}{l}\text { "Formulate and Enact Historic } \\
\text { District Zoning for the South } \\
\text { Main Street Historic District, } \\
\text { and examine other potential } \\
\text { candidate areas for designation } \\
\text { within the town (Housing } \\
\text { Implementation, E.14)." }\end{array}$ & $\begin{array}{l}\text { Two new zoning districts were recently } \\
\text { adopted--Village Main Street and Village } \\
\text { Rural--regulations include design standards }\end{array}$ \\
\hline & $\begin{array}{l}\text { "Work to identify and protect } \\
\text { archeological sites through the } \\
\text { development of site plan } \\
\text { review requirements (Natural \& } \\
\text { Cultural Resources } \\
\text { Implementation, E.21)." }\end{array}$ & \\
\hline
\end{tabular}




\begin{tabular}{|l|l|l|}
\hline Issue Area & $\begin{array}{l}\text { Comprehensive Planning } \\
\text { Objective }\end{array}$ & Implementation \\
\hline
\end{tabular}

\begin{tabular}{|c|c|c|}
\hline $\begin{array}{l}\text { Village/Rural } \\
\text { Character } \\
\text { (continued) }\end{array}$ & & \\
\hline & $\begin{array}{l}\text { "The town should create a } \\
\text { Design Review Board to review } \\
\text { development proposals (Natural } \\
\text { \& Cultural Plan Element, D.19)." }\end{array}$ & Planning Department \\
\hline & $\begin{array}{l}\text { "Evaluate and nominate } \\
\text { potentially eligible structures to } \\
\text { the National Registry by } \\
\text { property owners-- (Natural \& } \\
\text { Cultural Resources } \\
\text { Implementation, E.21)." }\end{array}$ & Not Adopted \\
\hline & $\begin{array}{l}\text { "Formulate, adopt and } \\
\text { administer a town Landscape } \\
\text { Ordinance-- (Natural \& } \\
\text { Cultural Resources } \\
\text { Implementation, E.21)." }\end{array}$ & $\begin{array}{l}\text { The town has adopted a new Tree } \\
\text { Ordinance }\end{array}$ \\
\hline & $\begin{array}{l}\text { The town should adopt a 'View } \\
\text { Protection Overlay Ordinance' } \\
\text { which will designate areas of } \\
\text { the town where views from } \\
\text { public places should be } \\
\text { preserved (Natural \& Cultural } \\
\text { Plan Element, D.19)." }\end{array}$ & Not Adopted \\
\hline & $\begin{array}{l}\text { "The town should adopt the } \\
\text { Scenic Highway System } \\
\text { developed by the Rhode Island } \\
\text { Scenic Highway Board to } \\
\text { evaluate and designate scenic } \\
\text { corridors in the town (Natural } \\
\text { \& Cultural Plan Element, D.19)." }\end{array}$ & Not Adopted \\
\hline & $\begin{array}{l}\text { "The town of Coventry should } \\
\text { develop Historic Overlay } \\
\text { Zoning to protect the resources } \\
\text { and integrity of its historic } \\
\text { districts (Natural \& Cultural } \\
\text { Plan Element, D.19)." } \\
\end{array}$ & $\begin{array}{l}\text { Adopted new zoning districts and design } \\
\text { standards for Village Main Street and } \\
\text { Village Rural }\end{array}$ \\
\hline & $\begin{array}{l}\text { - "The town should require } \\
\text { archaeological surveys in the } \\
\text { site plan review process } \\
\text { (Natural \& Cultural Plan } \\
\text { Element, D.19)." }\end{array}$ & \\
\hline
\end{tabular}




\begin{tabular}{|l|l|l|}
\hline Issue Area & Municipal Protection Measures & Implementation \\
\hline
\end{tabular}

\begin{tabular}{|c|c|c|}
\hline $\begin{array}{l}\text { Land } \\
\text { Conservation }\end{array}$ & & \\
\hline $\begin{array}{l}\text { Farmland } \\
\text { Preservation }\end{array}$ & & \\
\hline Zoning Regulations & $\begin{array}{l}\text { Residential Cluster, General } \\
\text { Requirements (any parcel containing land } \\
\text { that is classified as Prime Farmland or } \\
\text { Farmland of Statewide Importance, and has } \\
\text { been under cultivation at any time during } \\
\text { the five years preceding subdivision } \\
\text { application, shall be designed as a residential } \\
\text { cluster development or residential } \\
\text { compound in such a way as to preserve } 50 \% \\
\text { of the farmland for agricultural uses, } \\
\text { provided the characteristics of the parcel are } \\
\text { such that the farmland is capable of being } \\
\text { arranged in a lot of at least five contiguous } \\
\text { acres; may be granted a } 20 \% \text { bonus in the } \\
\text { number of lots) }\end{array}$ & Implemented \\
\hline Site Design & 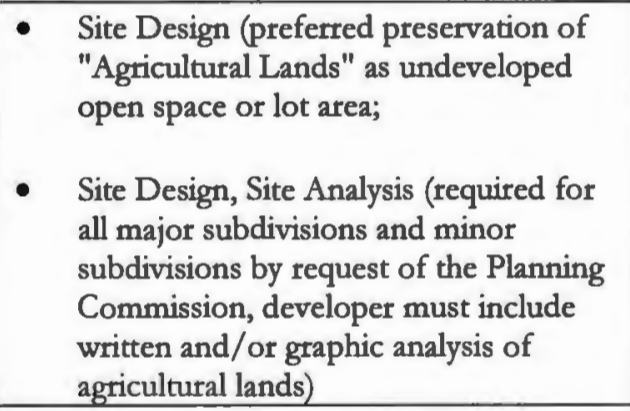 & $\begin{array}{l}\text { Subdivision regulations } \\
\text { allow for flexibility in } \\
\text { reducing road widths } \\
\text { and public-rights-of-way } \\
\text { and frontage setbacks to } \\
\text { promote better design } \\
\text { options. }\end{array}$ \\
\hline Other & - Farm, Forest and Open Space Progtam & $\begin{array}{l}\text { Coventry's minimum } \\
\text { parcel size is very low at } \\
10 \text { acres, the town has } \\
\text { many participating } \\
\text { properties }\end{array}$ \\
\hline Open Space Zoning & $\begin{array}{l}\text { No } \\
\text { "Open Lands" classified as } \\
\text { conservation lands, wildlife areas, and } \\
\text { nature preserves are allowed by right in } \\
\text { all zoning districts. Open lands } \\
\text { operated as commercial picnic groves } \\
\text { are allowed by special permit in RR5 } \\
\text { and RR2 districts and prohibited in all } \\
\text { other districts }\end{array}$ & $\begin{array}{l}\text { The Zoning Officer and } \\
\text { the Planner do not think } \\
\text { it is necessary (also, they } \\
\text { don't understand the } \\
\text { principle of open space } \\
\text { zoning or how to } \\
\text { determine the zone) }\end{array}$ \\
\hline
\end{tabular}




\section{Coventry Municipal Protections}

\begin{tabular}{|l|l|l|}
\hline Issue Area & Municipal Protection Measures & Implementation \\
\hline
\end{tabular}

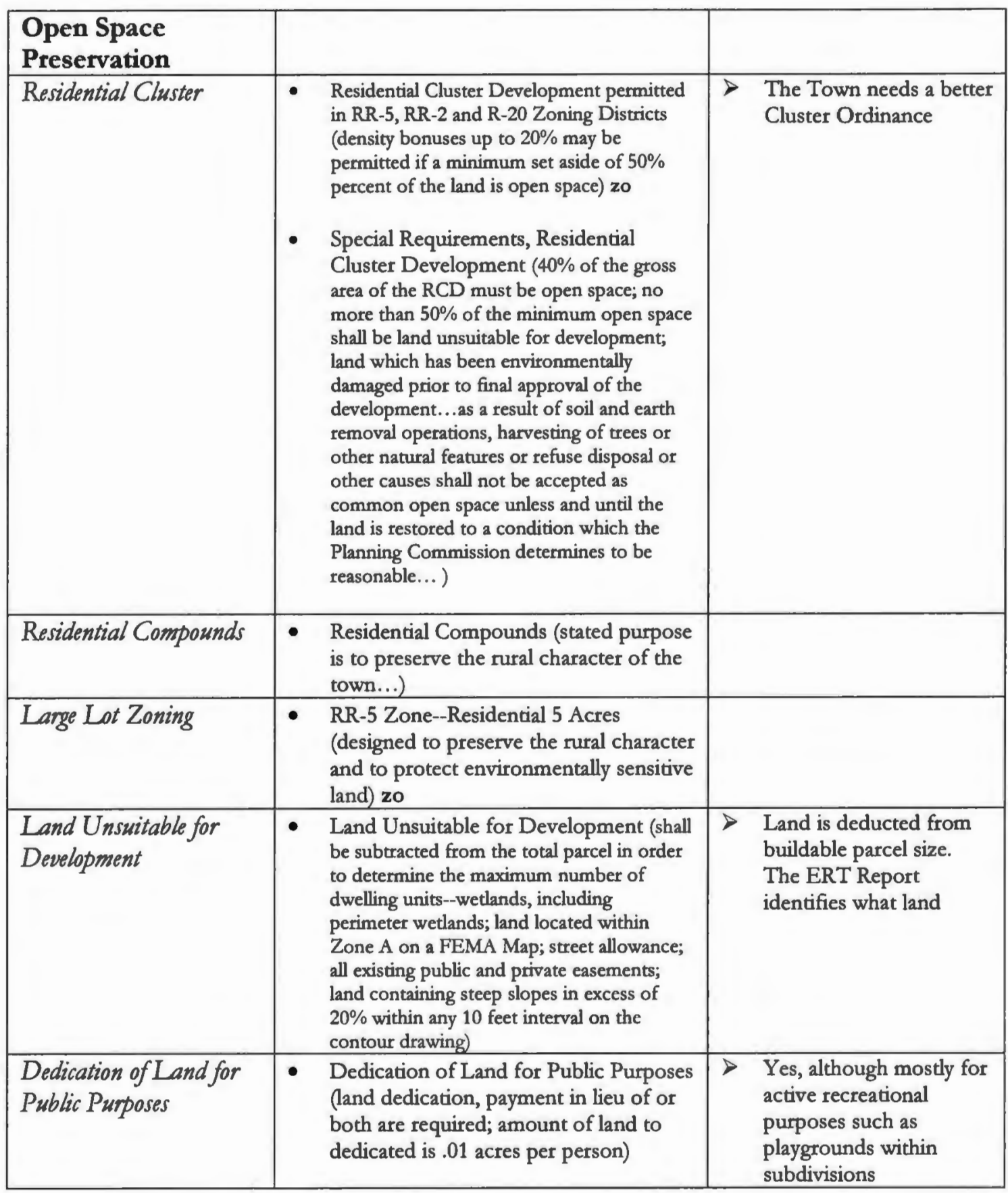




\begin{tabular}{|l|l|l|}
\hline Issue Area & Municipal Protection Measures & Implementation \\
\hline
\end{tabular}

\begin{tabular}{|l|l|l|}
\hline $\begin{array}{l}\text { Open Space } \\
\text { Preservation } \\
\text { (continued) }\end{array}$ & $\begin{array}{l}\text { Site Design (The following areas shall } \\
\text { be preserved as undeveloped open } \\
\text { space or lot area, to the extent } \\
\text { consistent with the reasonable } \\
\text { utilization of land-unique and/or fragile } \\
\text { areas, including freshwater wetlands; } \\
\text { significant trees or stands of trees, or } \\
\text { other vegetative species that are rare to } \\
\text { the area or are of particular horticultural } \\
\text { or landscape value; land in the flood } \\
\text { plain; steep slopes in excess of 20\% } \\
\text { unless appropriate engineering } \\
\text { measures are taken into consideration; } \\
\text { habitat of endangered wildlife; } \\
\text { historically significant structures and } \\
\text { sites; agricultural lands) }\end{array}$ & $\begin{array}{l}\text { The town has a new } \\
\text { Tree Ordinance that will } \\
\text { help protect significant } \\
\text { trees or strands of trees. } \\
\text { Vegetative species that } \\
\text { are rare to the area are } \\
\text { not adequately protected } \\
\text { unless an ERT is } \\
\text { conducted. }\end{array}$ \\
\hline Site Plan Review & $\begin{array}{l}\text { Development Plan Review, Criteria } \\
\text { (required for any residential project not } \\
\text { requiring subdivision approval that } \\
\text { exceeds 6 dwellings, construction or } \\
\text { expansion of all non-residential sites, } \\
\text { applications requiring a special use } \\
\text { permit, zoning map change or variance- } \\
\text {-Building sites shall, to the extent } \\
\text { feasible: maximize open space } \\
\text { retention...) }\end{array}$ & $>$ Planned Unit \\
Developments
\end{tabular}




\begin{tabular}{|l|l|l|}
\hline Issue Area & Municipal Protection Measures & Implementation \\
\hline
\end{tabular}

\begin{tabular}{|c|c|c|}
\hline $\begin{array}{l}\text { Natural Resource } \\
\text { Protection }\end{array}$ & & \\
\hline \multicolumn{3}{|l|}{ Wetlands } \\
\hline $\begin{array}{l}\text { Erosion and Sediment } \\
\text { Control Plan }\end{array}$ & $\begin{array}{l}\text { Erosion and Sediment Control Plan } \\
\text { (required for all land developments and } \\
\text { subdivisions) zo }\end{array}$ & $\begin{array}{l}\text { A fee and monitoring } \\
\text { schedule are prepared. } \\
\text { The Planner or someone } \\
\text { from the Southem RI } \\
\text { Conservation District } \\
\text { inspects sites. } \\
>\quad \text { Strictly monitored }\end{array}$ \\
\hline $\begin{array}{l}\text { Land Unsuitable for } \\
\text { Development }\end{array}$ & $\begin{array}{l}\text { - Wetlands are considered "land } \\
\text { unsuitable for development" }\end{array}$ & Strictly adhered to \\
\hline $\begin{array}{l}\text { Environmental } \\
\text { Analysis/Impact } \\
\text { Statement }\end{array}$ & $\begin{array}{l}\text { Environmental Review Team Report } \\
\text { (The Planning Commission may require the } \\
\text { applicant to pay for an ERT prepared by the } \\
\text { RI Resource Conservation and } \\
\text { Development Council, Inc.--if all or part of } \\
\text { the property is identified in the Natural and } \\
\text { Cullural Resources Element of the } \\
\text { Comprehensive Plan; the Planning } \\
\text { Commission finds that there is reasonable } \\
\text { expectation...of negative environmental } \\
\text { impact...) }\end{array}$ & $\begin{array}{l}\text { The ERT Report assists } \\
\text { the town in identifying } \\
\text { important constraints to } \\
\text { development (however, } \\
\text { lacks sufficient } \\
\text { recommendations) }\end{array}$ \\
\hline Site Design & $\begin{array}{l}\text { - Site Design (preferred preservation of } \\
\text { freshwater wetlands as undeveloped } \\
\text { open space or lot area) } \\
\\
\text { - Site Design, Site Analysis (required for } \\
\text { all major subdivisions and minor } \\
\text { subdivisions by request of the Planning } \\
\text { Commission, developer must include } \\
\text { written and/or graphic analysis of } \\
\text { wetlands and an assessment describing } \\
\text { potential effects of the proposed } \\
\text { development) }\end{array}$ & $>$ Strictly adhered to \\
\hline Site Plan Review & $\begin{array}{l}\text { - Development Plan Review, Criteria } \\
\text { (required for any residential project not requiring } \\
\text { subdivision approval that exceeds } 6 \text { dwellings, } \\
\text { construction or expansion of all non-residencial } \\
\text { sites, applications requiring a special use permit, } \\
\text { zoning map change or variance--Building sites } \\
\text { shall, to the extent feasible: minimize use of } \\
\text { wetlands...) }\end{array}$ & Strictly adhered to \\
\hline Performance Standards & $\begin{array}{l}\text { - Hazardous Waste Management } \\
\text { Facilities, Siting Restrictions (shall be } \\
\text { prohibited in environmentally sensitive } \\
\text { areas) }\end{array}$ & Strictly adhered to \\
\hline
\end{tabular}




\begin{tabular}{|l|l|l|}
\hline Issue Area & Municipal Protection Measures & Implementation \\
\hline
\end{tabular}

\begin{tabular}{|c|c|c|}
\hline $\begin{array}{l}\text { Watercourses/ } \\
\text { Surface Waters }\end{array}$ & & \\
\hline $\begin{array}{l}\text { Erosion and Sediment } \\
\text { Control Plan }\end{array}$ & $\begin{array}{l}\text { Erosion and Sediment Control Plan } \\
\text { (required for all land developments and } \\
\text { subdivisions) zo }\end{array}$ & $\begin{array}{l}\text { Well implemented } \\
\text { A fee and monitoring } \\
\text { schedule are prepared. } \\
\text { The Planner or someone } \\
\text { from the Southern RI } \\
\text { Conservation District } \\
\text { inspects sites }\end{array}$ \\
\hline Protection District & & $\begin{array}{l}\text { The Town is currently } \\
\text { working on a Watershed } \\
\text { Protection District or } \\
\text { overlay zone }\end{array}$ \\
\hline $\begin{array}{l}\text { Environmental } \\
\text { Analysis/Impact } \\
\text { Statement }\end{array}$ & $\begin{array}{l}\text { Environmental Review Team Report } \\
\text { (The Planning Commission. may require if } \\
\text { all or part of the property is identified in the } \\
\text { Natural and Cultural Resources Element of } \\
\text { the Comprehensive Plan; the Planning } \\
\text { Commission finds that there is reasonable } \\
\text { expectation... of negative environmental } \\
\text { impact...) }\end{array}$ & $\begin{array}{l}\text { The ERT Report assists } \\
\text { the town in identifying } \\
\text { protection methods. }\end{array}$ \\
\hline Site Design & $\begin{array}{l}\text { Site Design, Site Analysis (required for } \\
\text { all major subdivisions and minor } \\
\text { subdivisions by request of the Planning } \\
\text { Commission, developer must include } \\
\text { written and/or graphic analysis of } \\
\text { wetlands and an assessment describing } \\
\text { potential effects of the proposed } \\
\text { development) }\end{array}$ & $>$ Adhered to \\
\hline Site Plan Review & $\begin{array}{l}\text { Development Plan Review, Criteria (the } \\
\text { development plan shall show adequate } \\
\text { measures to prevent pollution of surface or } \\
\text { groundwater, to minimize erosion and } \\
\text { sedimentation, and to prevent changes in } \\
\text { groundwater levels, increased runoff and } \\
\text { potential for flooding...) zo } \\
\text { Development Plan Review, Criteria } \\
\text { (Building sites shall, to the extent feasible: } \\
\text { prevent depletion or degradation of public } \\
\text { drinking water supplies by employing best } \\
\text { management practices for erosion control, } \\
\text { storm water management, wastewater } \\
\text { disposal and landscaping) }\end{array}$ & $\begin{array}{l}\text { The town mandates use } \\
\text { of the Department of } \\
\text { Transportation's list of } \\
\text { "BMPs" for stormwater } \\
\text { management. }\end{array}$ \\
\hline Performance Standards & $\begin{array}{l}\text { Performance Standards for Sewage and } \\
\text { Water-borne Wastes(All industrial uses } \\
\text { shall develop a Stormwater Management } \\
\text { Plan which is approved by the Planning } \\
\text { Commission prior to receiving a building } \\
\text { permit) zo }\end{array}$ & $>$ Implemented \\
\hline Other & $\begin{array}{l}\text { Hazardous Waste Management } \\
\text { Facilities, Siting Restrictions (shall be } \\
\text { prohibited in environmentally sensitive } \\
\text { areas) zo }\end{array}$ & Implemented \\
\hline
\end{tabular}




\section{Coventry Municipal Protections}

\begin{tabular}{|l|l|l|}
\hline Issue Area & Municipal Protection Measures & Implementation \\
\hline
\end{tabular}

\begin{tabular}{|c|c|c|c|}
\hline $\begin{array}{l}\text { Groundwater/ } \\
\text { Recharge Areas }\end{array}$ & & & \\
\hline Protection District & & $>$ & $\begin{array}{l}\text { The Town Council has } \\
\text { requested a Watershed } \\
\text { Protection District that } \\
\text { establishes specific } \\
\text { watershed growth } \\
\text { management controls to } \\
\text { minimize impacts on } \\
\text { water quality, and } \\
\text { protect groundwater and } \\
\text { wetlands resources. }\end{array}$ \\
\hline $\begin{array}{l}\text { Environmental } \\
\text { Analysis/Impact } \\
\text { Statement }\end{array}$ & $\begin{array}{l}\text { - Environmental Review Team Report } \\
\text { (The Planning Commission. may require the } \\
\text { applicant to pay for an ERT prepared by the } \\
\text { RI Resource Conservation and } \\
\text { Development Council, Inc.--if all or part of } \\
\text { the property is identified in the Natural and } \\
\text { Cultural Resources Element of the } \\
\text { Comprehensive Plan; the Planning } \\
\text { Commission finds that there is reasonable } \\
\text { expectation of negative environmental } \\
\text { impact...) }\end{array}$ & $>$ & $\begin{array}{l}\text { The ERT Report assists } \\
\text { the town in identifying } \\
\text { protection methods. }\end{array}$ \\
\hline Site Design & $\begin{array}{l}\text { Site Design Standards (development shall } \\
\text { be laid out to avoid adversely affecting } \\
\text { ground water and aquifer recharge; to } \\
\text { reduce cut and fill; to avoid unnecessary } \\
\text { impervious cover and to prevent } \\
\text { flooding...) }\end{array}$ & $>$ & $\begin{array}{l}\text { (Probably to the extent } \\
\text { that an ERT has helped } \\
\text { to identify appropriate } \\
\text { site protection measures) } \\
\text { The Planning } \\
\text { Commission may reduce } \\
\text { road width standards or } \\
\text { approve a private, non- } \\
\text { impervious road surface. }\end{array}$ \\
\hline Site Plan Reviezy & $\begin{array}{l}\text { Development Plan Review, Criteria (the } \\
\text { development plan shall show adequate } \\
\text { measures to prevent pollution of surface or } \\
\text { groundwater, to minimize erosion and } \\
\text { sedimentation, and to prevent changes in } \\
\text { groundwater levels, increased runoff and } \\
\text { potential for flooding...) zo }\end{array}$ & & $\begin{array}{l}\text { (Probably to the extent } \\
\text { that an ERT has helped } \\
\text { to identify appropriate } \\
\text { site protection measures) }\end{array}$ \\
\hline Other & $\begin{array}{l}\text { - Hazardous Waste Management } \\
\text { Facilities, Siting Restrictions (shall be } \\
\text { prohibited in environmentally sensitive } \\
\text { areas) }\end{array}$ & & Strictly adhered to \\
\hline
\end{tabular}




\section{Coventry Municipal Protections}

\begin{tabular}{|l|l|l|}
\hline Issue Area & Municipal Protection Measures & Implementation \\
\hline
\end{tabular}

\begin{tabular}{|c|c|c|}
\hline Floodplains & & \\
\hline \multicolumn{3}{|l|}{ Protection District } \\
\hline $\begin{array}{l}\text { Land Unsuitable for } \\
\text { Development }\end{array}$ & - Land Unsuitable for development & Strictly adhered to \\
\hline $\begin{array}{l}\text { Environmental } \\
\text { Analysis/Impact } \\
\text { Statement }\end{array}$ & $\begin{array}{l}\text { ERT (Environmental Review Team Report) } \\
\text { may be required by Planning Commission. }\end{array}$ & \\
\hline Site Design & $\begin{array}{l}\text { - Site Design (preferred preservation of lands } \\
\text { in the floodplain as undeveloped open space } \\
\text { or lot area) } \\
\text { - Site Design Standards (development shall be } \\
\text { laid out to reduce cut and fill; to avoid } \\
\text { unnecessary impervious cover; to prevent } \\
\text { flooding...) }\end{array}$ & $\begin{array}{l}\text { Implemented through } \\
\text { cluster and site plan } \\
\text { review provisions } \\
\text { The town encourages } \\
\text { private, impervious } \\
\text { surfaced roads in cluster } \\
\text { and residential } \\
\text { compounds }\end{array}$ \\
\hline Site Plan Review & $\begin{array}{l}\text { Development Plan Review, Criteria } \\
\text { (Building sites shall, to the extent feasible: } \\
\text { minimize use of floodplains...) } \\
\text { - Development Plan Review, Criteria (the } \\
\text { development plan shall show adequate } \\
\text { measures to prevent changes in gtoundwater } \\
\text { levels, increased nunoff and potential for } \\
\text { flooding...) zo }\end{array}$ & $\begin{array}{l}\text { (Probably to the extent } \\
\text { that an ERT has helped } \\
\text { to identify appropriate } \\
\text { site protection measures) }\end{array}$ \\
\hline Performance Principles & $\begin{array}{l}\text { Hazardous Waste Management Facilities, } \\
\text { Siting Restrictions (shall be prohibited in } \\
\text { environmentally sensitive areas) }\end{array}$ & $>$ Strictly adhered to \\
\hline
\end{tabular}




\section{Coventry Municipal Protections}

\begin{tabular}{|l|l|l|}
\hline Issue Area & Municipal Protection Measures & Implementation \\
\hline
\end{tabular}

\begin{tabular}{|c|c|c|}
\hline Topography & & \\
\hline $\begin{array}{l}\text { Emsion and Sediment } \\
\text { Control Plan }\end{array}$ & $\begin{array}{l}\text { Erosion and Sediment Control Plan } \\
\text { (required for all land developments and } \\
\text { subdivisions) zo }\end{array}$ & $>$ Strictly adhered to \\
\hline $\begin{array}{l}\text { Land Unsuitable for } \\
\text { Development }\end{array}$ & $\begin{array}{l}\text { Land unsuitable for development (steep } \\
\text { slopes in excess of } 20 \% \text { within any } 10 \text { feet } \\
\text { interval on the contour drawing) }\end{array}$ & Strictly adhered to \\
\hline $\begin{array}{l}\text { Environmental } \\
\text { Analysis/Impact } \\
\text { Statement }\end{array}$ & $\begin{array}{l}\text { - } \quad \text { ERT (Environmental Review Team Report) } \\
\text { may be required by Planning Commission. }\end{array}$ & \\
\hline Site Design & $\begin{array}{l}\text { - Site Design (preferred preservation of steep } \\
\text { slopes in excess of } 20 \% \text { as undeveloped } \\
\text { open space or lot area; site analysis require } \\
\text { for all major subdivisions and minor } \\
\text { subdivisions by request of the Planning } \\
\text { Commission) } \\
\text { - Site Design, Site Analysis (required for all } \\
\text { major subdivisions and minor subdivisions } \\
\text { by request of the Planning Commission, } \\
\text { developer must include written and/or } \\
\text { graphic analysis of topography and an } \\
\text { assessment describing potential effects of } \\
\text { the proposed development) }\end{array}$ & $\begin{array}{l}\begin{array}{l}\text { Implemented through } \\
\text { cluster and site plan } \\
\text { review provisions }\end{array} \\
>\text { Adhered to }\end{array}$ \\
\hline Site Plan Review & $\begin{array}{l}\text { Development Plan Review, Criteria } \\
\text { (Building sites shall, to the extent feasible: } \\
\text { minimize use of steep slopes...minimize } \\
\text { tree, vegetation and soil removal, grade } \\
\text { changes and subsequent erosion) }\end{array}$ & Strictly adhered to \\
\hline
\end{tabular}




\section{Coventry Municipal Protections}

\begin{tabular}{|l|l|l|}
\hline Issue Area & Municipal Protection Measures & Implementation \\
\hline
\end{tabular}

\begin{tabular}{|c|c|c|}
\hline $\begin{array}{l}\text { Rare Species/ } \\
\text { Critical Habitat }\end{array}$ & & \\
\hline \multicolumn{3}{|l|}{$\begin{array}{l}\text { Land Unsuitable for } \\
\text { Development }\end{array}$} \\
\hline $\begin{array}{l}\text { Environmental } \\
\text { Analysis/ Impact } \\
\text { Statement }\end{array}$ & $\begin{array}{l}\text { ERT (Environmental Review Team Report) } \\
\text { may be required by Planning Commission. }\end{array}$ & $\begin{array}{l}\text { The ERT identifies rate } \\
\text { species and critical } \\
\text { habitat. }\end{array}$ \\
\hline Site Design & $\begin{array}{l}\text { - Site Design (preferred preservation of } \\
\text { habitats of endangered wildlife as } \\
\text { undeveloped open space or lot area; site } \\
\text { analysis required for all major subdivisions } \\
\text { and minor subdivisions by request of the } \\
\text { Planning Commission) } \\
\text { - Site Design (preferred preservation of } \\
\text { significant trees or stands of trees, or other } \\
\text { vegetative species that are rare to the area or } \\
\text { are of particular horticultural or landscape } \\
\text { value as undeveloped open space or lot area; } \\
\text { site analysis require for all major } \\
\text { subdivisions and minor subdivisions by } \\
\text { request of the Planning Commission) } \\
\text { Site Design, Site Analysis (required for all } \\
\text { major subdivisions and minor subdivisions } \\
\text { by request of the Planning Commission, } \\
\text { developer must include written and/or } \\
\text { graphic analysis of wetlands, ecology and } \\
\text { existing vegetation and an assessment } \\
\text { describing potential effects of the proposed } \\
\text { development) }\end{array}$ & $\begin{array}{l}\text { The Planner and Zoning } \\
\text { Officer do not seem to } \\
\text { understand how to use } \\
\text { the Natural Heritage } \\
\text { Maps to identify critical } \\
\text { site considerations } \\
\text { Need assistance from } \\
\text { the State--need a system } \\
\text { or procedure to follow. }\end{array}$ \\
\hline Site Plan Revien & $\begin{array}{l}\text { Development Plan Review, Criteria } \\
\text { (Building sites shall, to the extent feasible: } \\
\text { minimize tree, vegetation and soil removal; } \\
\text { preserve unique natural features...) }\end{array}$ & Strictly implemented \\
\hline Other & & \\
\hline
\end{tabular}




\section{Coventry Municipal Protections}

\begin{tabular}{|l|l|l|}
\hline Issue Area & Municipal Protection Measures & Implementation \\
\hline
\end{tabular}

\begin{tabular}{|c|c|c|}
\hline Trees/Woodlands & & \\
\hline $\begin{array}{l}\text { Erosion and Sediment } \\
\text { Control Plan }\end{array}$ & $\begin{array}{l}\text { Erosion and Sediment Control Plan } \\
\text { (required for all land developments and } \\
\text { subdivisions) zo }\end{array}$ & \\
\hline $\begin{array}{l}\text { Environmental } \\
\text { Analysis/ } \\
\text { Impact Statement }\end{array}$ & $\begin{array}{l}\text { ERT (Environmental Review Team } \\
\text { Report) may be required by Planning } \\
\text { Commission }\end{array}$ & \\
\hline Site Design & $\begin{array}{l}\text { - Site Design (preferred preservation of } \\
\text { significant trees or stands of trees, or } \\
\text { other vegetative species that are rare to } \\
\text { the area or area of particular } \\
\text { horticultural or landscape value as } \\
\text { undeveloped open space or lot area; site } \\
\text { analysis require for all major } \\
\text { subdivisions and minor subdivisions by } \\
\text { request of the Planning Commission) } \\
\text { - Site Design, Site Analysis (required for } \\
\text { all major subdivisions and minor } \\
\text { subdivisions by request of the Planning } \\
\text { Commission, developer must include } \\
\text { written and/or graphic analysis of } \\
\text { wetlands, ecology and existing } \\
\text { vegetation and an assessment describing } \\
\text { potential effects of the proposed } \\
\text { development) }\end{array}$ & $\begin{array}{l}\text { The Planner and } \\
\text { Zoning Officer do not } \\
\text { seem to understand how } \\
\text { to use the Natural } \\
\text { Heritage Maps to } \\
\text { identify vegetative species } \\
\text { that are rare to the area or } \\
\text { areas of particular } \\
\text { horticultural or landscape } \\
\text { value ) }\end{array}$ \\
\hline Site Plan Review & $\begin{array}{l}\text { Development Plan Review, Criteria } \\
\text { (required for any residential project not } \\
\text { requiring subdivision approval that } \\
\text { exceeds } 6 \text { dwellings, construction or } \\
\text { expansion of all non-residential sites, } \\
\text { applications requiring a special use } \\
\text { permit, zoning map change or variance- } \\
\text { - Building sites shall, to the extent } \\
\text { feasible: minimize tree, vegetation and } \\
\text { soil removal; preserve unique natural } \\
\text { features...) }\end{array}$ & \\
\hline Landscape Plan & $\begin{array}{l}\text { Landscaping, Landscape Standards and } \\
\text { Specification (applies to all non- } \\
\text { residential and multifamily residential } \\
\text { projects--existing trees and woodlands } \\
\text { shall be preserved to the greatest extent } \\
\text { possible...) }\end{array}$ & \\
\hline Other & - New Tree Ordinance & \\
\hline
\end{tabular}




\section{TOWN OF EXETER PROFILE}

\section{Summary}

Exeter is one of the only towns in the study area that is not experiencing significant growth pressures. A notable portion of the Town's land area is comprised of permanently protected state and federal lands. Much of the Town's remaining developable land is zoned for very low density residential (R-3 and R-4 districts). Given these conditions, there has been little perceived need for large investments in town planning, and as a result the Town's planning capacity is low. There is a growing awareness, however, among local decision-makers of the need for stronger development regulations and more comprehensive, long-term planning. The development proposal for the Ladd Center has been a catalyst for new planning initiatives.

The Town will need significant revisions to both its comprehensive plan and its development regulations to adequately manage an increased growth rate in commercial and residential development. Based on the interview conducted for this study, there does not appear to be broad-based political support for a number of the policy objectives found in the 1990 comprehensive plan. Consequently, planning officials and residents cannot easily refer to the document, as it was intended, as an authoritative guide to regulatory changes. The Town's development regulations do not include a residential cluster or residential compound development ordinance. Exeter is the only town in the study area that does not identify "land unsuitable for development," nor does it establish site design standards.

The Town's subdivision and land development regulations have been recently updated to include a mandatory impact statement for all major subdivisions and land developments. The regulation also gives the planning board authority to require a more detailed environmental impact statement (EIS) for any development if deemed necessary. The Town has also adopted a 
development plan review ordinance with strict environmental performance standards and mandatory "best management practices" for stormwater management and erosion and sediment control. Exeter is in the process of establishing a local land trust, strengthening its groundwater protection ordinance, and finding new ways to promote farmland preservation. It is one of the few towns in the study area that allows farming, raising of animals, and forestry by right in most zoning districts.

\section{Planning Department}

Exeter currently employs one half-time planner. The Town has very little technical planning capacity, and no in-house GIS capabilities. The slow pace of development historically did not necessitate full planning capacity. Exeter's town planning officials are becoming increasingly aware of the technical requirements needed to successfully implement a number of the Town's development regulations (e.g., the groundwater protection ordinance). Exeter's planning board is very knowledgeable and committed to increased land conservation and natural resource protection. The town planner maintains a strong working relationship with the board.

Planning capacity limitations in Exeter revolve around a need for updating the Town's regulations and comprehensive plan, increased technical support and research. Most importantly, the Town needs increased training and education for town decision-makings to help build broader awareness and consensus around land conservation and natural resource protection issues.

\section{Comprehensive Plan Objectives}

Exeter's comprehensive plan objectives touch on many of the natural resource and land conservation issues identified in this study. The Town has adopted or is in the process of adopting many of the significant policy objectives outlined in the plan. For example, the Town has hired Newport Collaborative to assist in identifying innovative ways to preserve agricultural land, an important objective in the plan. The Town is also working with Rhode 
Island Department of Environmental Management to explore new ways to maintain forestry operations. The Town adopted EIS regulations, environmental performance standards in its development plan review, and a groundwater protection district, all important comprehensive plan objectives. The Town will need to establish a municipal land trust to further a number of the objectives outlined in the plan.

\section{Site Analysis}

The town planner interviewed for this study had not had an opportunity to review a major subdivision proposal. Therefore, information on site analysis in this profile is very limited. The Town appears to rely on its mandatory impact statement for detailed information pertaining to environmental considerations in site design. A full EIS is required if all or part of the land has been identified by the planning board, conservation commission, the Rhode Island Natural Heritage Program, the Rhode Island Historic Preservation and Heritage Commission, The Nature Conservancy, RIDEM, the U.S. Geological Survey, or the U.S. EPA, as unique natural areas or areas of critical and/or environmental concern; or if the planning board feels it is necessary to prevent negative environmental impacts.

The EIS requirement is an important tool for protecting environmentally sensitive features on a site, particularly if the Town lacks in-house technical capacity. Exeter lacks important site design standards, flexible cluster design options, and a determination of "land unsuitable for development" to help guide development away from environmentally sensitive areas. Without these provisions in its regulations, it would be very difficult for the Town to institute environmentally sensitive development practices. 


\section{Zoning and Subdivision Regulations}

\section{Zoning Ordinances}

- Farmland Zoning - Raising of animals is allowed either by right or by special use permit in all zones except Business (B); farming and forestry are allowed by right or by special use permit in all zones except Light Industrial (LI)

- Residential Cluster Development-none

- Large Lot Residential Zoning-The Town is zoned primarily for very low residential development (RU-3, RU-4, and 5 acre Conservation/Recreation/Residential District)

- Overlay Districts-Groundwater Protection Overlay District

- Site Plan Review-Development Plan Review, provides strict environmental performance standards for water bodies and requires the use of "best management practices" for stormwater management and erosion and sediment control.

- Performance Standards-(see Development Plan Review)

\section{Subdivision and Land Development Regulations}

- Land Unsuitable for Development-none

- Environmental Analysis-Regulations include a mandatory "Impact Statement" for all major subdivisions and land developments and an EIS for any development at the request of the planning board.

- Erosion and Sediment Control-Exeter requires an "Erosion and Sediment Control Plan" for all developments. The Town strictly monitors the plan. It also works to establish "best management practices" for stormwater management and erosion and sediment control.

- Site Design Standards-none 


\begin{tabular}{|l|l|l|}
\hline Issue Area & $\begin{array}{l}\text { Comprehensive Planning } \\
\text { Objective }\end{array}$ & Implementation \\
\hline
\end{tabular}

\begin{tabular}{|c|c|c|}
\hline $\begin{array}{l}\text { Land } \\
\text { Conservation }\end{array}$ & & \\
\hline \multicolumn{3}{|l|}{$\begin{array}{l}\text { Farmland } \\
\text { Preservation }\end{array}$} \\
\hline & $\begin{array}{l}\text { Institute regulations that } \\
\text { encourage the continued use of } \\
\text { prime famland for the } \\
\text { preservation of open space, } \\
\text { natural habitats and agricultural } \\
\text { purposes }\end{array}$ & $\begin{array}{l}\text { Yes, see regulations to promote } \\
\text { farmland preservation }\end{array}$ \\
\hline & $\begin{array}{l}\text { Investigate additional means and } \\
\text { methods for preserving } \\
\text { agricultural land. These could } \\
\text { include establishment of an } \\
\text { Agricultural Land Trust and a } \\
\text { mechanism for the transfer of } \\
\text { development rights }\end{array}$ & $\begin{array}{l}\text { Newport Collaborative Report } \\
\text { addressing these issues } \\
\text { The planning board is working to } \\
\text { provide new opportunities for farmland } \\
\text { preservation }\end{array}$ \\
\hline \multicolumn{3}{|l|}{$\begin{array}{l}\text { Open Space } \\
\text { Zoning }\end{array}$} \\
\hline & $\begin{array}{l}\text { Zone open space areas such as } \\
\text { state parks and lands held by the } \\
\text { Audubon Society, private } \\
\text { organizations and other lands } \\
\text { under open space easements as } \\
\text { Open Space, to prevent their } \\
\text { reuse for some other purpose }\end{array}$ & $\begin{array}{l}\text { Eventually, zoning changes are very } \\
\text { time consuming }\end{array}$ \\
\hline \multicolumn{3}{|l|}{$\begin{array}{l}\text { Open Space } \\
\text { Preservation }\end{array}$} \\
\hline & $\begin{array}{l}\text { - Strengthen the Town's efforts to } \\
\text { acquire or otherwise protect all } \\
\text { water bodies, wet areas, streams } \\
\text { and other natural resources }\end{array}$ & $\begin{array}{l}\text { Groundwater Protection Overlay } \\
\text { District }\end{array}$ \\
\hline & $\begin{array}{l}\text { Establish a progressive policy } \\
\text { toward open space as a positive } \\
\text { element in improving the Town's } \\
\text { economy }\end{array}$ & $\begin{array}{l}\text { Town is supportive of TNC and other } \\
\text { acquisition strategies and proponents of } \\
\text { open space }\end{array}$ \\
\hline
\end{tabular}




\section{Exeter Comprehensive Plan Matrix}

\begin{tabular}{|l|l|l|}
\hline Issue Area & $\begin{array}{l}\text { Comprehensive Planning } \\
\text { Objective }\end{array}$ & Implementation \\
\hline
\end{tabular}

\begin{tabular}{|c|c|c|}
\hline $\begin{array}{l}\text { Open Space } \\
\text { Preservation } \\
\text { (continued) }\end{array}$ & & \\
\hline & $\begin{array}{l}\text { Pursue the purchase of } \\
\text { easements to allow public access } \\
\text { to lakes, ponds, and rivers for } \\
\text { canoeing, hiking and fishing. } \\
\text { These easements could also } \\
\text { serve to keep development set } \\
\text { back from sensitive Town waters }\end{array}$ & \\
\hline & $\begin{array}{l}\text { The Town should encourage the } \\
\text { establishment of land trusts to } \\
\text { help preserve sensitive natural } \\
\text { areas and open space }\end{array}$ & $\begin{array}{l}\text { The town is working towards the } \\
\text { establishment of a land trust }\end{array}$ \\
\hline & $\begin{array}{l}\text { Establish a sound and } \\
\text { continuous Capital } \\
\text { Improvement Program to } \\
\text { efficiently allocate funds for } \\
\text { orderly acquisition and } \\
\text { development of recreation } \\
\text { facilities and open space } \\
\text { tesources according to the } \\
\text { priority needs of the Town and } \\
\text { in a manner to take advantage of } \\
\text { Federal and State matching } \\
\text { programs }\end{array}$ & Not adopted \\
\hline & $\begin{array}{l}\text { The Town should amend its } \\
\text { subdivision regulations to } \\
\text { provide for the dedication of } \\
\text { land for recreation or } \\
\text { conservation by developers }\end{array}$ & $\begin{array}{l}\text { Adopted--Dedication of Land for } \\
\text { Public Purposes }\end{array}$ \\
\hline
\end{tabular}




\section{Exeter Comprehensive Plan Matrix}

\begin{tabular}{|l|l|l|}
\hline Issue Area & $\begin{array}{l}\text { Comprehensive Planning } \\
\text { Objective }\end{array}$ & Implementation \\
\hline
\end{tabular}

\begin{tabular}{|c|c|c|}
\hline $\begin{array}{l}\text { Natural } \\
\text { Resource } \\
\text { Protection }\end{array}$ & & \\
\hline & $\begin{array}{l}\text { It is recommended that } \\
\text { Environmental Performance } \\
\text { Standards be incorporated into } \\
\text { the Town's Zoning \& } \\
\text { Subdivision Regulations. The } \\
\text { standards would institute a Best } \\
\text { Management Practice (BMP) } \\
\text { policy requirement }\end{array}$ & $\begin{array}{l}\text { Performance standards are part of } \\
\text { Development Plan Review } \\
\text { The planning board can require BMPs } \\
\text { through the EIS process }\end{array}$ \\
\hline & $\begin{array}{l}\text { Incorporate an Environmental } \\
\text { Impact requirement for large } \\
\text { residential, commercial and } \\
\text { industrial projects }\end{array}$ & Adopted \\
\hline & $\begin{array}{l}\text { Require innovative land use } \\
\text { techniques to avoid or minimize } \\
\text { development impacts to natural } \\
\text { resources }\end{array}$ & $>$ In the process \\
\hline Wetlands & & \\
\hline & $\begin{array}{l}\text { Require vegetative buffers for all } \\
\text { surface water bodies and } \\
\text { wetlands to protect water quality } \\
\text { and wildlife habitat }\end{array}$ & $>$ Relies on DEM's standards \\
\hline & $\begin{array}{l}\text { - Strengthen the Town's efforts to } \\
\text { acquire or otherwise protect all } \\
\text { water bodies, wet areas, streams } \\
\text { and other natural resources }\end{array}$ & $D$ In the process \\
\hline $\begin{array}{l}\text { Watercourses/ } \\
\text { Surface Waters }\end{array}$ & & \\
\hline & $\begin{array}{l}\text { - Strengthen the Town's efforts to } \\
\text { acquire or otherwise protect all } \\
\text { water bodies, wet areas, streams } \\
\text { and other natural resources }\end{array}$ & $>$ In the process \\
\hline
\end{tabular}




\begin{tabular}{|l|l|l|}
\hline Issue Area & $\begin{array}{l}\text { Comprehensive Planning } \\
\text { Objective }\end{array}$ & Implementation \\
\hline
\end{tabular}

\begin{tabular}{|c|c|c|}
\hline $\begin{array}{l}\text { Groundwater/ } \\
\text { Recharge } \\
\text { Areas }\end{array}$ & & \\
\hline & $\begin{array}{l}\text { Adopt a groundwater protection } \\
\text { ordinance to limit or prohibit land } \\
\text { uses with a potential to contaminate } \\
\text { or pollute surface or groundwater } \\
\text { and limit the removal of outwash } \\
\text { materials in aquifers }\end{array}$ & $>$ Adopted \\
\hline & $\begin{array}{l}\text { - The town should establish a } \\
\text { High Water Table Overlay } \\
\text { District }\end{array}$ & $>$ Not adopted \\
\hline & $\begin{array}{l}\text { A program of acquisition of land } \\
\text { and the purchase of } \\
\text { conservation easements should } \\
\text { be immediately implemented to } \\
\text { insure the protection of the } \\
\text { Queen's River aquifer as a } \\
\text { potential water supply }\end{array}$ & $>$ Not adopted \\
\hline Floodplains & & \\
\hline $\begin{array}{l}\text { Coastal } \\
\text { Features }\end{array}$ & & \\
\hline Topography & & \\
\hline & $\begin{array}{l}\text { Establish regulations governing } \\
\text { alteration of sites having grades } \\
\text { in excess of } 15 \% \text {. The } \\
\text { regulations should specifically } \\
\text { address methods for soil } \\
\text { removal, stabilization and } \\
\text { erosion control. }\end{array}$ & $>$ Not adopted \\
\hline $\begin{array}{l}\text { Rare Species/ } \\
\text { Critical } \\
\text { Habitat } \\
\end{array}$ & & \\
\hline & $\begin{array}{l}\text { Require vegetative buffers from } \\
\text { all surface water bodies and } \\
\text { wetlands to protect water quality } \\
\text { and wildlife habitat }\end{array}$ & Not adopted \\
\hline $\begin{array}{l}\text { Trees/ } \\
\text { Woodlands }\end{array}$ & & \\
\hline & $\begin{array}{l}\text { The Town should designate the } \\
\text { Planning Board or Conservation } \\
\text { Commission to be responsible to } \\
\text { disseminate information regarding } \\
\text { state or federal govemment 'Forest } \\
\text { Legacy Programs' }\end{array}$ & $>$ (I think adopted0 \\
\hline
\end{tabular}




\begin{tabular}{|l|l|l|}
\hline Issue Area & $\begin{array}{l}\text { Comprehensive Planning } \\
\text { Objective }\end{array}$ & Implementation \\
\hline
\end{tabular}

\begin{tabular}{|c|c|c|}
\hline $\begin{array}{l}\text { Cultural and } \\
\text { Historic } \\
\text { Resources } \\
\end{array}$ & & \\
\hline $\begin{array}{l}\text { Village/Rural } \\
\text { Character }\end{array}$ & & \\
\hline & $\begin{array}{l}\text { Use the Town's Zoning } \\
\text { Ordinance to effectively } \\
\text { preserve and enhance } \\
\text { historical and cultural locale } \\
\text { by incorporating scenic, } \\
\text { conservation and aesthetic } \\
\text { controls }\end{array}$ & \\
\hline & $\begin{array}{l}\text { Establish a number of } \\
\text { planned districts, including } \\
\text { village center districts, } \\
\text { industrial and commercial } \\
\text { planned development districts } \\
\text { and special use districts, } \\
\text { which would include the Ladd } \\
\text { Center District and the } \\
\text { Dorset Mill District. }\end{array}$ & $\begin{array}{l}\text { Adopted Planned Unit Development } \\
\text { Village Center District } \\
\quad \text { Residential Planned Districts in the works }\end{array}$ \\
\hline & $\begin{array}{l}\text { Encourage small-scaled, } \\
\text { clustered, architecturally } \\
\text { sensitive, landscaped } \\
\text { shopping areas consistent } \\
\text { with the rural town } \\
\text { character, with adequate } \\
\text { off-street parking and } \\
\text { loading areas included in } \\
\text { overall site design }\end{array}$ & See Development Plan Review \\
\hline & $\begin{array}{l}\text { Amend the subdivision } \\
\text { regulations to include a } \\
\text { variety of new road } \\
\text { standards that relate future } \\
\text { design criteria and width to } \\
\text { the ultimate function of } \\
\text { the roadway as opposed to } \\
\text { the current standard of one } \\
\text { design for all new roads, } \\
\text { irrespective of its function } \\
\text { and ultimate use }\end{array}$ & $>$ Not adopted \\
\hline & $\begin{array}{l}\text { Update and make universally } \\
\text { applicable the Site Plan } \\
\text { Review Requirements that are } \\
\text { currently embodied in the } \\
\text { Subdivision Ordinance and } \\
\text { adopt them as a separate Site } \\
\text { Plan Review Ordinance. }\end{array}$ & $>$ Adopted \\
\hline
\end{tabular}




\begin{tabular}{|l|l|l|}
\hline Issue Area & Municipal Protection Measure & Implementation \\
\hline
\end{tabular}

\begin{tabular}{|c|c|c|}
\hline \multicolumn{3}{|l|}{$\begin{array}{l}\text { Land } \\
\text { Conservation }\end{array}$} \\
\hline \multicolumn{3}{|l|}{$\begin{array}{l}\text { Farmland } \\
\text { Preservation } \\
\end{array}$} \\
\hline Zoning Regulations & $\begin{array}{l}\text { RU-3 and RU-4 (Rural Districts)--The } \\
\text { stated purpose of the RU-4 district is to } \\
\text { protect land now used for forestry, } \\
\text { farming, and related activities and the } \\
\text { natural habitat and wildlife and to } \\
\text { preserve the area's rural character. Zo } \\
\text { - Raising of animals is allowed either by } \\
\text { right or by special use permit in all } \\
\text { zones except Business (B) zo } \\
\text { - Farming and forestry are allowed by } \\
\text { right or special use permit in all zones } \\
\text { except Light Industrial (LD) zo }\end{array}$ & \\
\hline \multicolumn{3}{|l|}{ Site Design } \\
\hline Other & - Farm, Forest and Open Space Program & \\
\hline Open Space Zoning & $\begin{array}{l}\text { Residential Single-Family, raising of } \\
\text { animals, farming, and roadside stands, } \\
\text { municipal buildings are allowed by } \\
\text { special use permit zo }\end{array}$ & \\
\hline \multicolumn{3}{|l|}{$\begin{array}{l}\text { Open Space } \\
\text { Preservation }\end{array}$} \\
\hline \multicolumn{3}{|l|}{ Cluster Development } \\
\hline \multicolumn{3}{|l|}{ Residential Compounds } \\
\hline Large Lot Zoning & $\begin{array}{l}\text { Rural Residential Zoning Districts; } 5 \\
\text { acre Conservation/Recreation District } \\
\text { zo }\end{array}$ & \\
\hline \multicolumn{3}{|l|}{$\begin{array}{l}\text { Land Unsuitable for } \\
\text { Development }\end{array}$} \\
\hline $\begin{array}{l}\text { Dedication of Land for } \\
\text { Public Purposes }\end{array}$ & $\begin{array}{l}\text { Dedication of Land for Public Purposes } \\
\text { (minimum amount is } 3 \% \text { of total gross } \\
\text { acres of development parcel) }\end{array}$ & \\
\hline \multicolumn{3}{|l|}{ Site Design } \\
\hline Other & & \\
\hline
\end{tabular}




\begin{tabular}{|l|l|l|}
\hline Issue Area & Municipal Protection Measure & Implementation \\
\hline
\end{tabular}

\begin{tabular}{|c|c|c|}
\hline $\begin{array}{l}\text { Natural Resource } \\
\text { Protection }\end{array}$ & & \\
\hline \multicolumn{3}{|l|}{ Wetlands } \\
\hline $\begin{array}{l}\text { Erosion and Sediment } \\
\text { Control Plan }\end{array}$ & $\begin{array}{l}\text { Erosion and Sediment Control Plan } \\
\text { (required for all development) }\end{array}$ & Adhered to \\
\hline \multicolumn{3}{|l|}{$\begin{array}{l}\text { Land Unsuitable for } \\
\text { Development }\end{array}$} \\
\hline $\begin{array}{l}\text { Environmental } \\
\text { Analysis/Impact } \\
\text { Statement }\end{array}$ & $\begin{array}{l}\text { General Requirements, Project } \\
\text { description and impact statement } \\
\text { (Narrative description and impact } \\
\text { report required for all major } \\
\text { subdivisions and land developments; an } \\
\text { EIS may be required for any } \\
\text { development at the request of the } \\
\text { Planning Board) }\end{array}$ & $>$ Strictly adhered to \\
\hline Site Design & $\begin{array}{l}\text { Design Standards (freshwater wetlands } \\
\text { cannot be excavated, drained, filled nor } \\
\text { shall any extraneous materials be placed } \\
\text { into these wetlands) }\end{array}$ & Adhered to \\
\hline Site Plan Review & $\begin{array}{l}\text { Development Plan Review, Stormwater } \\
\text { runoff and erosion control(Direct } \\
\text { discharge of untreated stormwater } \\
\text { runoff to a wetland or water course } \\
\text { from impervious surfaces...shall not be } \\
\text { allowed)zo } \\
\text { - Development Plan Review, Water } \\
\text { bodies, (Whenever situated in the whole } \\
\text { or in part, within } 300 \text { feet of any pond, } \\
\text { lake, river or other freshwater wetland, } \\
\text { the proposed project shall not adversely } \\
\text { effect the quality of such body of water } \\
\text { or unreasonably affect the shoreline of } \\
\text { such body of water. There will be no } \\
\text { disturbance of soil within } 100 \text { feet of } \\
\text { the outer edge of a wetland (as defined } \\
\text { by DEM) zo }\end{array}$ & $>$ Adhered to \\
\hline Performance Standards & & \\
\hline
\end{tabular}




\begin{tabular}{|l|l|l|}
\hline Issue Area & Municipal Protection Measure & Implementation \\
\hline
\end{tabular}

\begin{tabular}{|c|c|c|}
\hline $\begin{array}{l}\text { Watercourses/ } \\
\text { Surface Waters }\end{array}$ & & \\
\hline $\begin{array}{l}\text { Erosion and Sediment } \\
\text { Control Plan }\end{array}$ & $\begin{array}{l}\text { Erosion and Sediment Control } \\
\text { Performance Principles (Development } \\
\text { plans shall preserve salient natural } \\
\text { features, keep cut and fill operations to } \\
\text { a minimum and ensure conformity with } \\
\text { topography so as to adequately handle } \\
\text { the volume and velocity of surface } \\
\text { water runoff, and create the least } \\
\text { erosion potential) }\end{array}$ & Adhered to \\
\hline \multicolumn{3}{|l|}{ Protection District } \\
\hline $\begin{array}{l}\text { Environmental } \\
\text { Analysis/Impact } \\
\text { Statement }\end{array}$ & $\begin{array}{l}\text { General Requirements, Project } \\
\text { description and impact statement } \\
\text { (Narrative description and impact } \\
\text { report required for all major } \\
\text { subdivisions and land developments; an } \\
\text { EIS may be required for any } \\
\text { development at the request of the } \\
\text { Planning Board }\end{array}$ & $>$ Adhered to \\
\hline \multicolumn{3}{|l|}{ Site Design } \\
\hline Site Plan Review & $\begin{array}{l}\text { Development Plan Review (required for } \\
\text { all permitted uses other than one or two } \\
\text { family dwellings or accessory buildings; } \\
\text { adherence to the RI Stormwater Runoff } \\
\text { and RI Erosion and Sediment Control } \\
\text { Handbooks is required) zo } \\
\text { Development Plan Review, Water } \\
\text { bodies, (Whenever situated in the whole } \\
\text { or in part, within } 300 \text { feet of any pond, } \\
\text { lake, river or other freshwater wetland, } \\
\text { the proposed project shall not adversely } \\
\text { effect the quality of such body of water } \\
\text { or unreasonably affect the shoreline of } \\
\text { such body of water. There will be no } \\
\text { disturbance of soil within } 100 \text { feet of } \\
\text { the outer edge of a wetland (as defined } \\
\text { by DEM)) zo }\end{array}$ & Adhered to \\
\hline \multicolumn{3}{|l|}{ Performance Standards } \\
\hline Other & & \\
\hline
\end{tabular}




\begin{tabular}{|l|l|l|}
\hline Issue Area & Municipal Protection Measure & Implementation \\
\hline
\end{tabular}

\begin{tabular}{|c|c|c|}
\hline $\begin{array}{l}\text { Groundwater/ } \\
\text { Recharge Areas }\end{array}$ & & \\
\hline Protection District & $\begin{array}{l}\text { - Groundwater Protection Overlay } \\
\text { District zo }\end{array}$ & $\begin{array}{l}\text { Needs to be } \\
\text { strengthened }\end{array}$ \\
\hline $\begin{array}{l}\text { Environmental } \\
\text { Analysis/Impact } \\
\text { Statement }\end{array}$ & $\begin{array}{l}\text { General Requirements, Project } \\
\text { description and impact statement } \\
\text { (Narrative description and impact } \\
\text { report required for all major } \\
\text { subdivisions and land developments; an } \\
\text { EIS may be required if land is identified } \\
\text { as either unique natural area or area of } \\
\text { environmental concern or at the request } \\
\text { of the planning board) }\end{array}$ & $>$ Strictly adhered to \\
\hline \multicolumn{3}{|l|}{ Site Design } \\
\hline Site Plan Review & $\begin{array}{l}\text { Development Plan Review (The project } \\
\text { shall be designed to prevent the } \\
\text { pollution of surface or ground water } \\
\text { resources; the planning board may } \\
\text { require specific site designs, best } \\
\text { management practices, and/or } \\
\text { applicable management measures to } \\
\text { protect surface and ground water } \\
\text { quality) zo }\end{array}$ & $>$ Adhered to \\
\hline \multicolumn{3}{|l|}{ Other } \\
\hline \multicolumn{3}{|l|}{ Floodplains } \\
\hline \multicolumn{3}{|l|}{ Protection District } \\
\hline \multicolumn{3}{|l|}{$\begin{array}{l}\text { Land Unsuitable for } \\
\text { Development }\end{array}$} \\
\hline $\begin{array}{l}\text { Environmental } \\
\text { Analysis/Impact } \\
\text { Statement }\end{array}$ & $\begin{array}{l}\text { General Requirements, Project } \\
\text { description and impact statement } \\
\text { (Narrative description and impact } \\
\text { report required for all major } \\
\text { subdivisions and land developments; an } \\
\text { EIS may be required for any } \\
\text { development at the request of the } \\
\text { Planning Board) }\end{array}$ & \\
\hline \multicolumn{3}{|l|}{ Site Design } \\
\hline \multicolumn{3}{|l|}{ Site Plan Review } \\
\hline Performance Principles & & \\
\hline
\end{tabular}




\begin{tabular}{|l|l|l|}
\hline Issue Area & Municipal Protection Measure & Implementation \\
\hline
\end{tabular}

\begin{tabular}{|c|c|c|}
\hline Topography & & \\
\hline $\begin{array}{l}\text { Erosion and Sediment } \\
\text { Control Plan }\end{array}$ & $\begin{array}{l}\text { Erosion and Sediment Control } \\
\text { Performance Principles (Development } \\
\text { plans shall preserve salient natural } \\
\text { features, keep cut and fill operations to } \\
\text { a minimum and ensure conformity with } \\
\text { topography so as to adequately handle } \\
\text { the volume and velocity of surface } \\
\text { water runoff, and create the least } \\
\text { erosion potential) }\end{array}$ & Strictly adhered to \\
\hline \multicolumn{3}{|l|}{$\begin{array}{l}\text { Land Unsuitable for } \\
\text { Development }\end{array}$} \\
\hline $\begin{array}{l}\text { Environmental } \\
\text { Analysis/Impact } \\
\text { Statement }\end{array}$ & $\begin{array}{l}\text { General Requirements, Project } \\
\text { description and impact statement } \\
\text { (Narrative description and impact } \\
\text { report required for all major } \\
\text { subdivisions and land developments; an } \\
\text { EIS may be required for any } \\
\text { development at the request of the } \\
\text { Planning Board) }\end{array}$ & \\
\hline Site Design & $\begin{array}{l}\text { Land development and subdivision } \\
\text { design standards, specific, Lots (slopes } \\
\text { over } 12 \% \text {, and bedrock areas may be a } \\
\text { determining factor in effecting lot size } \\
\text { due to the effect this has on onsite } \\
\text { (proposed) sewage systems) }\end{array}$ & \\
\hline Site Plan Review & $\begin{array}{l}\text { Development Plan Review (adherence } \\
\text { to the RI Stormwater Runoff and RI } \\
\text { Erosion and Sediment Control } \\
\text { Handbooks is required) zo } \\
\text { - Development Plan Review, } \\
\text { Landscaping (The landscape shall be } \\
\text { preserved in its natural state insofar as } \\
\text { practicable by minimizing tree removal, } \\
\text { disturbance of the soil and retaining } \\
\text { existing vegetation during and after } \\
\text { construction; Existing trees and } \\
\text { vegetation shall be preserved to the } \\
\text { maximum extent possible) zo }\end{array}$ & \\
\hline
\end{tabular}




\begin{tabular}{|l|l|l|}
\hline Issue Area & Municipal Protection Measure & Implementation \\
\hline
\end{tabular}

\begin{tabular}{|c|c|c|}
\hline \multicolumn{3}{|l|}{$\begin{array}{l}\text { Rare Species/ } \\
\text { Critical Habitat }\end{array}$} \\
\hline $\begin{array}{l}\text { Land Unsuitable for } \\
\text { Development }\end{array}$ & & \\
\hline $\begin{array}{l}\text { Environmental } \\
\text { Analysis/ Impact } \\
\text { Statement }\end{array}$ & $\begin{array}{l}\text { General Requirements, Project } \\
\text { description and impact statement } \\
\text { (Narrative description and impact } \\
\text { report required for all major } \\
\text { subdivisions and land developments; an } \\
\text { EIS may be required for any } \\
\text { development at the request of the } \\
\text { Planning Board or if site is identified by } \\
\text { DEM's Natural Heritage Program) }\end{array}$ & Strictly adhered to \\
\hline \multicolumn{3}{|l|}{ Site Design } \\
\hline Site Plan Review & $\begin{array}{l}\text { Development Plan Review (states that } \\
\text { there must not be any undue adverse } \\
\text { effect on the scenic or natural beauty of } \\
\text { the project area, aesthetics, historic } \\
\text { sites, or rare and irreplaceable natural } \\
\text { areas) zo }\end{array}$ & \\
\hline Other & $\begin{array}{l}\text { RU-4 (Rural District)--The stated } \\
\text { purpose of the district is to protect land } \\
\text { now used for forestry, farming, and } \\
\text { related activities and the natural habitat } \\
\text { and wildlife and to preserve the area's } \\
\text { rural character zo } \\
\text { Master Plan approval requires a } \\
\text { verification letter from DEM's Natural } \\
\text { Heritage Program zo }\end{array}$ & $>$ Strictly adhered to \\
\hline
\end{tabular}




\begin{tabular}{|l|l|l|}
\hline Issue Area & Municipal Protection Measure & Implementation \\
\hline
\end{tabular}

\begin{tabular}{|l|l|l|}
\hline $\begin{array}{l}\text { Trees/ } \\
\text { Woodlands }\end{array}$ & \\
\hline $\begin{array}{l}\text { Erosion and Sediment } \\
\text { Control Plan }\end{array}$ & $\begin{array}{l}\text { Erosion and Sediment Control } \\
\text { Performance Principles (Whenever } \\
\text { feasible, natural vegetation shall be } \\
\text { retained, protected, and supplemented) }\end{array}$ & $>$ Adhered to \\
\hline $\begin{array}{l}\text { Analysis/ } \\
\text { Impact Statement }\end{array}$ & $\begin{array}{l}\text { General Requirements, Project } \\
\text { description and impact statement } \\
\text { Narrative description and impact } \\
\text { report required for all major } \\
\text { subdivisions and land developments; an } \\
\text { EIS may be required for any } \\
\text { development at the request of the } \\
\text { Planning Board or if site is identified as } \\
\text { an area of critical or environmental } \\
\text { concern) }\end{array}$ & \\
\hline Site Design & $\begin{array}{l}\text { Development Plan Review (landscape } \\
\text { plan requirements state that existing } \\
\text { trees and vegetation shall be preserved } \\
\text { to the maximum extent possible; the } \\
\text { plan must include the approximate } \\
\text { location of wooded areas, wetlands and } \\
\text { coastal features) zo }\end{array}$ & Adhered to \\
\hline Site Plan Review & $\begin{array}{l}\text { RU-4 (Rural District)--The stated } \\
\text { purpose of the district is to protect land } \\
\text { now used for forestry, farming, and } \\
\text { related activities and the natural habitat } \\
\text { and wildlife and to preserve the area's } \\
\text { rural character. zo }\end{array}$ & \\
\hline Other & Strictly adhered to \\
\hline
\end{tabular}




\section{TOWN OF HOPKINTON PROFILE}

\section{Summary}

The Town of Hopkinton is in the process of adjusting to unprecedented suburban growth pressures and increasing local concern for land preservation and natural resource protection. In comparison to other towns in the study, Hopkinton's current planning capacity is low. The Town's 1991 comprehensive plan objectives for land conservation and natural resource protection need to be revised. Plan objectives do not adequately reflect present levels of environmental concern, particularly in the area of impacts from development. The Town's existing subdivision and land development regulations incorporate very few measures to promote environmentally sensitive development. In addition, the Town lacks the technical capacity to conduct its own site analysis, and is almost completely reliant on the developer for site information. The absence of an environmental analysis requirement in the subdivision and land development regulations further limits the Town's access to critical parcel information.

Local concern for land conservation and natural resource protection is rising, however. Town officials are openly concerned with preserving rural character and protecting the Town's drinking water supplies. The town planner is in the process of updating the Town's development regulations. The Town has recently established the Hopkinton Land Trust to help manage land acquisition and conservation efforts, and the town council is in the process of adopting a new groundwater protection overlay district.

\section{Planning Department}

The Hopkinton Planning Department has one full-time planner. The town planner is concerned about land conservation and natural resource protection, but does not have a background in environmental management. To compensate for this lack of knowledge, she consults frequently with other planners in the region. She works primarily with the Hopkinton Planning 
Board, though she attends the monthly meetings of the town council and other boards and commissions to educate decision-makers on the need for better long-term planning. According to the town planner, the planning board is experienced and does a good job, despite the Town's weak subdivision and land development regulations.

Planning capacity limitations in the town range from understaffing and lack of resources to limited technical and regulatory capacity to manage current levels of growth. At present, the planning board often relies on informal procedures to both assess and direct individual developments. For example, the planning board uses the "abutters notice" to garner important information on the proposed development site. In other words, abutting property owners are relied upon for information concerning the suitability of the site for a particular development proposal. The planning board also relies heavily on "conditions of approval" to strike deals with developers concerning site design standards. This rather arbitrary process would be unnecessary if the Town required detailed environmental analysis and site analysis for major subdivisions and land developments. If these provisions were adopted, the developer would be required to provide in-depth information on the environmental characteristics of the site, as well as a description of how environmental impacts would be minimized.

\section{Comprehensive Plan Objectives}

Many of the 1991 comprehensive plan objectives focus on the need to establish guidelines and acquisitions strategies for land conservation. The establishment of a land trust was an important step towards implementing a number of the plan's objectives. The Town recently voted to grant $\$ 250,000$ to the new land trust.

The new groundwater protection ordinance also fulfils an important objective of the 1991 plan. However, the comprehensive plan should be updated to 
include more detailed and informed policy objectives for protecting the Town's water resources, wetlands, forests and critical habitat.

\section{Site Analysis}

Hopkinton is very much in need of better site analysis procedures and development regulations. The planning department's lack of in-house GIS capacity, coupled with the absence of a mandatory regulation requiring a detailed environmental analysis, makes it very difficult for the Town to institute environmentally sensitive development practices. This is particularly the case for larger sites, where it is not possible for the town planner or the planning board to conducted extensive onsite environmental assessments. Instead, the planning board may request an impact statement that asks for research and documentation describing and assessing short and long term environmental impacts. This provision is not mandatory, however.

Hopkinton's site design standards list environmentally sensitive areas that should be preserved and protected in the development of the site. The design standards do not include, however, a site analysis provision requiring developers to demonstrate how they intend to minimize environmental impacts. The planning board may request an impact statement and/or an alternative residential cluster design, if deemed necessary, to better protect environmental features on the site.

\section{Zoning and Subdivision Regulations}

\section{Zoning Ordinances}

- Residential Cluster Development-See Subdivision and Land Development Regulations (below)

- Large Lot Residential Zoning-Hopkinton's Rural Farming Residential (R80) District allows farming operations by right. According to the town planner, this provision, coupled with the "Residential Compound" site design, has encouraged the preservation of farmland and open space in town. 
- Overlay Districts-The Town's "Floodplain and Watercourse Protection District" provides extra oversight for the planning board. The ordinance does not exceed state standards.

- Site Plan Review-The Town's "Development Plan Review" ordinance incorporates limited provisions for the protection of environmentally sensitive areas. For example, the ordinance does not mandate a detailed environmental analysis of the site. Nor does the ordinance require a detailed "site analysis," demonstrating how the developer intends to protect sensitive natural features on the site. Such considerations need be made only to the extent "practicable" for the developer.

- Performance Standards-none

\section{Subdivision and Land Development Regulations}

- Residential Cluster Development-The Town's "Residential Cluster" and "Residential Compound" site design regulations are popular, though not mandatory. Residential cluster development regulations only require that 30 percent of the total area be preserved as open space. The regulation excludes any wetlands, ponds, marshes, protected natural areas, areas classified as unique, and slopes greater than 15 percent from the calculation. These exclusion may add considerable to the actually percent land preserved as open space in the site design.

- Land Unsuitable for Development-Shall be deducted from the minimum building acreage of the parcel--freshwater wetlands, areas within a High Flood Danger zone, and land within any publicly or privately held easement on which above-ground utilities, including but not limited to electrical transmission lines, are constructed; land with slopes in excess of 15 percent.

- Environmental Analysis-The planning board may request an "Impact Statement" including research and documentation describing and assessing short and long term environmental impacts.

- Erosion and Sediment Control-The Town mandates an "Erosion and Sediment Control Plan" for all major subdivisions and land developments and for minor or administrative subdivisions if deemed necessary by the planning board. Both the building inspector and the public works director monitor sites.

- Site Design Standards-The Town's "Site Design Standards" includes a comprehensive list of environmental considerations to be considered in the design of the site. However, the defined "extent" of consideration is weak, including language such as "where practicable" and "where feasible." 


\begin{tabular}{|l|l|l|}
\hline Issue Area & Comprehensive Planning Objective & Implementation \\
\hline
\end{tabular}

\begin{tabular}{|c|c|c|}
\hline $\begin{array}{l}\text { Farmland } \\
\text { Preservation }\end{array}$ & & \\
\hline & $\begin{array}{l}\text { Foster the continuation of working farms, } \\
\text { and preservation of existing, privately- } \\
\text { owned forests and open space through the } \\
\text { existing tax programs and through } \\
\text { acquisition of development rights by state } \\
\text { and private agencies }\end{array}$ & $>$ Talk to tax assessor \\
\hline & $\begin{array}{l}\text { - Establish programs to assist the agricultural } \\
\text { operations that are viable businesses }\end{array}$ & $\begin{array}{l}\text { There are only } 3 \text { or } 4 \\
\text { working farms left in the } \\
\text { town. }\end{array}$ \\
\hline \multicolumn{3}{|l|}{$\begin{array}{l}\text { Open Space } \\
\text { Zoning }\end{array}$} \\
\hline \multicolumn{3}{|l|}{$\begin{array}{l}\text { Open Space } \\
\text { Preservation }\end{array}$} \\
\hline & - Establish a Land Conservancy Trust & $\begin{array}{l}\text { Hopkinton Land Trust was } \\
\text { established last month with a } \\
\text { budget of } \$ 250,000 \\
\text { Also possibility of a revenue } \\
\text { from the Real Estate Tax } \\
\text { Stamp } \\
\end{array}$ \\
\hline & $\begin{array}{l}\text { Encourage the acquisition of open space } \\
\text { adjacent to existing large open space parcels }\end{array}$ & Has not been done \\
\hline & $\begin{array}{l}\text { Develop land use controls that encourage } \\
\text { creative land planning to reduce } \\
\text { development costs while preserving open } \\
\text { space and environmentally sensitive areas } \\
\text { not otherwise protected by local, state, and } \\
\text { federal law }\end{array}$ & $\begin{array}{l}\text { Planning Board uses the } \\
\text { Cluster Ordinance and the } \\
\text { Residential Compound } \\
\text { Ordinance to protect open } \\
\text { space. }\end{array}$ \\
\hline & $\begin{array}{l}\text { Develop a systematic program for } \\
\text { recreational improvements and open space } \\
\text { acquisition }\end{array}$ & $>$ Has not been done \\
\hline & $\begin{array}{l}\text { Develop a Capital Improvement Program } \\
\text { which should include major recreational } \\
\text { expenses such as land acquisition }\end{array}$ & $\begin{array}{l}\text { The Town does not have an } \\
\text { overall Capital Improvement } \\
\text { Plan or budget }\end{array}$ \\
\hline & $\begin{array}{l}\text { - Coordinate with the state, private and non- } \\
\text { profit conservation organizations and land- } \\
\text { owners to establish a greenway network } \\
\text { connecting the major development and } \\
\text { natural areas of the town }\end{array}$ & $>$ Has not been done \\
\hline & $\begin{array}{l}\text { Require open space and vegetated buffer } \\
\text { areas in cluster and residential compound } \\
\text { subdivisions and in planned unit } \\
\text { developments to be configured to contribute } \\
\text { to a connecting greenway program }\end{array}$ & $\begin{array}{l}\text { The town possesses a lot of } \\
\text { open space } \\
\text { There is no perceived need } \\
\text { for this }\end{array}$ \\
\hline
\end{tabular}




\begin{tabular}{|l|l|l|}
\hline Issue Area & Comprehensive Planning Objective & Implementation \\
\hline
\end{tabular}

\begin{tabular}{|c|c|c|}
\hline $\begin{array}{l}\text { Natural } \\
\text { Resource } \\
\text { Protection }\end{array}$ & & \\
\hline \multicolumn{3}{|l|}{ Wetlands } \\
\hline & $\begin{array}{l}\text { - Prepare amendments to local ordinances } \\
\text { which will enhance the protection of } \\
\text { valuable wetland systems }\end{array}$ & $\begin{array}{l}\text { Site design standards are used } \\
\text { to protect wetlands } \\
\text { The Cluster ordinance is also } \\
\text { used to protect wetlands on } \\
\text { site. }\end{array}$ \\
\hline & $\begin{array}{l}\text { Require that developers show the } \\
\text { environmental 'soundness' of projects' }\end{array}$ & $\begin{array}{l}\text { See Master Plan checklist for } \\
\text { environmental requirements }\end{array}$ \\
\hline \multicolumn{3}{|c|}{$\begin{array}{l}\text { Watercourses/ } \\
\text { Surface Waters }\end{array}$} \\
\hline & $\begin{array}{l}\text { In } 1971 \text { a Flood Plain and Water Course } \\
\text { Protection Zone was adopted. This places } \\
\text { a restriction on building within or near } \\
\text { streams and ponds, and in essence } \\
\text { protects these areas from disturbance }\end{array}$ & $\begin{array}{l}\text { Same as DEM's wetlands } \\
\text { requirements and setbacks }\end{array}$ \\
\hline & $\begin{array}{l}\text { Evaluate the Wood-Pawcatuck River } \\
\text { Association's proposal to preserve River } \\
\text { Corridors }\end{array}$ & $>$ No \\
\hline & $\begin{array}{l}\text { Require that developers show the } \\
\text { environmental 'soundness' of projects }\end{array}$ & $\begin{array}{l}\text { See Master Plan checklist for } \\
\text { environmental requirements }\end{array}$ \\
\hline \multicolumn{3}{|c|}{$\begin{array}{l}\text { Groundwater/ } \\
\text { Recharge Areas }\end{array}$} \\
\hline & $\begin{array}{l}\text { Adopt an Aquifer Protection Overlay } \\
\text { Ordinance }\end{array}$ & $>$ In the process \\
\hline & $\begin{array}{l}\text { Amend current ordinances to include soil } \\
\text { erosion and sedimentation controls }\end{array}$ & $\begin{array}{l}\text { Yes, for major subdivisions } \\
\text { and land developments }\end{array}$ \\
\hline & $\begin{array}{l}\text { Consider expansion of the existing Waste } \\
\text { Water Management District }\end{array}$ & $>$ Not on horizon \\
\hline & $\begin{array}{l}\text { - Require that developers show the } \\
\text { environmental 'soundness' of projects }\end{array}$ & $\begin{array}{l}\text { See Master Plan checklist for } \\
\text { environmental requirements }\end{array}$ \\
\hline Floodplains & $\begin{array}{l}\text { - In } 1971 \text { a Flood Plain and Water Course } \\
\text { Protection Zone was adopted. This places } \\
\text { a restriction on building within or near } \\
\text { streams and ponds, and in essence } \\
\text { protects these areas from disturbance }\end{array}$ & $\begin{array}{l}\text { Same as DEM's wetlands } \\
\text { requirements and setbacks }\end{array}$ \\
\hline
\end{tabular}




\section{Hopkinton Comprehensive Plan Matrix}

\begin{tabular}{|l|l|l|}
\hline Issue Area & Comprehensive Planning Objective & Implementation \\
\hline
\end{tabular}

\begin{tabular}{|c|c|c|}
\hline \multicolumn{3}{|l|}{$\begin{array}{l}\text { Coastal } \\
\text { Features } \\
\end{array}$} \\
\hline \multicolumn{3}{|l|}{ Topography } \\
\hline $\begin{array}{l}\text { Rare Species/ } \\
\text { Critical Habitat }\end{array}$ & $\begin{array}{l}\text { Identify the key parcels of land where } \\
\text { valuable wildlife habitat remains, as well as } \\
\text { tare and endangered species, and take } \\
\text { appropriate measures to preserve and } \\
\text { protect }\end{array}$ & $\begin{array}{l}\text { Uses data available from the } \\
\text { EDC web site }\end{array}$ \\
\hline \multicolumn{3}{|l|}{$\begin{array}{l}\text { Trees/ } \\
\text { Woodlands }\end{array}$} \\
\hline \multicolumn{3}{|l|}{$\begin{array}{l}\text { Village/Rural } \\
\text { Character }\end{array}$} \\
\hline & - Establish an Historic District Ordinance & Yes, for Hope Valley?? \\
\hline & $\begin{array}{l}\text { Undertake a review of existing areas of } \\
\text { mixed use to determine their ability to } \\
\text { absorb additional development }\end{array}$ & $>$ In the process \\
\hline & $\begin{array}{l}\text { - Concentrate major development and } \\
\text { community facilities in the established } \\
\text { villages, primarily Ashaway and Hope } \\
\text { Valley }\end{array}$ & Has not occurred. \\
\hline & $\begin{array}{l}\text { Large scale market level residential } \\
\text { projects should be required to provide all } \\
\text { necessary infrastructure improvements, } \\
\text { including off site drainage, septic and } \\
\text { water provisions }\end{array}$ & $>? ?$ \\
\hline & $\begin{array}{l}\text { Develop and enforce buffers and } \\
\text { transition zones to prevent future } \\
\text { commercial intrusion into residential } \\
\text { neighborhoods }\end{array}$ & $>? ?$ \\
\hline & $\begin{array}{l}\text { Consider designation of certain roads as } \\
\text { scenic highways and establish appropriate } \\
\text { front-yard setbacks (zoning) and cluster } \\
\text { subdivision configurations to protect the } \\
\text { natural and built features of the road edge. }\end{array}$ & $\begin{array}{l}\text { Presently considering } \\
\text { Planning Board actively } \\
\text { works with developers to } \\
\text { establish larger setbacks from } \\
\text { roads. }\end{array}$ \\
\hline & $\begin{array}{l}\text { Require effective landscaping in all } \\
\text { parking areas other than those of single } \\
\text { and two family residences. }\end{array}$ & Not a priority \\
\hline & $\begin{array}{l}\text { Establish a local sidewalk and street tree } \\
\text { policy and program to insure these } \\
\text { amenities for new development in the } \\
\text { villages and on major roads }\end{array}$ & $>$ Not a priority \\
\hline
\end{tabular}




\begin{tabular}{|l|l|l|}
\hline Issue Area & Municipal Protection Measures & Implementation \\
\hline
\end{tabular}

\begin{tabular}{|c|c|c|}
\hline $\begin{array}{l}\text { Farmland } \\
\text { Preservation }\end{array}$ & & \\
\hline Zoning Regulations & - Rural Farming Residential-80 District zo & $\begin{array}{l}\text { This ordinance preserves } \\
\text { farmland by allowing } \\
\text { farming operations by } \\
\text { right }\end{array}$ \\
\hline Site Design & $\begin{array}{l}\text { Site Design Standards (for major } \\
\text { subdivisions, agricultural lands shall be } \\
\text { preserved as undeveloped open space or } \\
\text { lot area where feasible) }\end{array}$ & $\begin{array}{l}\text { This regulation has been } \\
\text { used to preserve prime } \\
\text { agricultural soils in a } \\
\text { cluster subdivision }\end{array}$ \\
\hline Other Tool/Incentive & - Farm, Forest and Open Space Program? & \\
\hline $\begin{array}{l}\text { Open Space } \\
\text { Zoning }\end{array}$ & - No & \\
\hline $\begin{array}{l}\text { Open Space } \\
\text { Preservation }\end{array}$ & & \\
\hline $\begin{array}{l}\text { Residential Cluster } \\
\text { Development }\end{array}$ & $\begin{array}{l}\text { Residential Cluster Development allowed } \\
\text { in RFR- } 80 \text { District (minimum parcel size } \\
\text { is } 10 \text { acres, } 30 \% \text { of the total area of the } \\
\text { district must be permanent open space, } \\
\text { excluding roads, wetlands, ponds, } \\
\text { marshes, natural areas, areas classified as } \\
\text { unique, slopes greater than } 15 \% \text { ) zo }\end{array}$ & $\begin{array}{l}\text { Planning Board can } \\
\text { require Cluster } \\
\text { Need for more flexibility in } \\
\text { the regulations } \\
\text { The Planning Board prefers } \\
\text { the cluster ordinance be } \\
\text { voluntary; although the } \\
\text { board usually opts for a } \\
\text { cluster design } \\
\text { The Planner uses "Abutters } \\
\text { Notice" early in the project } \\
\text { review process, the Master } \\
\text { Plan Meeting, to help } \\
\text { identify "constraints to } \\
\text { development" and other } \\
\text { development concerns }\end{array}$ \\
\hline $\begin{array}{l}\text { Residential } \\
\text { Compounds }\end{array}$ & $\begin{array}{l}\text { - Residential Compounds (stated purpose } \\
\text { is rural preservation) zo }\end{array}$ & $\begin{array}{l}\text { The Residential } \\
\text { Compound option is very } \\
\text { popular } \\
\text { The Planner would like to } \\
\text { see this option expanded } \\
\text { by increasing the number } \\
\text { of permissible building } \\
\text { lots (presently a } \\
\text { maximum of } 7 \text {, with a } \\
\text { minimum of } 35 \text { acres) } \\
\text { Shared drives and gravel } \\
\text { roads are allowed in this } \\
\text { ordinance }\end{array}$ \\
\hline
\end{tabular}




\begin{tabular}{|l|l|l|}
\hline Issue Area & Municipal Protection Measures & Implementation \\
\hline
\end{tabular}

\begin{tabular}{|c|c|c|}
\hline $\begin{array}{l}\text { Open Space } \\
\text { Preservation } \\
\text { (continued) }\end{array}$ & & \\
\hline Lange Lot Zoning & - Rural Farming Residential-80 District zo & $\begin{array}{l}\text { This ordinance preserves } \\
\text { farmland by allowing } \\
\text { farming operations by } \\
\text { right }\end{array}$ \\
\hline $\begin{array}{l}\text { Land Unsuitable for } \\
\text { Development }\end{array}$ & $\begin{array}{l}\text { Land Unsuitable for Development (shall } \\
\text { be deducted from the minimum building } \\
\text { acreage of the parcel--freshwater } \\
\text { wetlands, areas within a High Flood } \\
\text { Danger zone, and land within any } \\
\text { publicly or privately held easement on } \\
\text { which above-ground utilities, including } \\
\text { but not limited to electrical transmission } \\
\text { lines, are constructed; land with slopes in } \\
\text { excess of } 15 \text { percent) }\end{array}$ & $\begin{array}{l}\text { Developers are required } \\
\text { to identify "land } \\
\text { unsuitable for } \\
\text { development" in Master } \\
\text { Plan (?) } \\
>\text { Planner conducts on-site } \\
\text { analysis } \\
\text { Planner uses "constraints } \\
\text { maps" } \\
\text { The Planner uses } \\
\text { "Abutters Notice" early in } \\
\text { the project review } \\
\text { process, the Master Plan } \\
\text { Meeting, to help identify } \\
\text { "constraints to } \\
\text { development" and other } \\
\text { development concerns }\end{array}$ \\
\hline $\begin{array}{l}\text { Open Space } \\
\text { Preservation } \\
\text { (continued) } \\
\end{array}$ & & \\
\hline $\begin{array}{l}\text { Dedication of Land for } \\
\text { Public Purposes }\end{array}$ & $\begin{array}{l}\text { Dedication of Land for Public Purposes } \\
\text { (may be required; amount of land to be } \\
\text { dedicated is .01 per person) }\end{array}$ & $\begin{array}{l}\text { Did not say how } \\
\text { extensively this is used or } \\
\text { how. }\end{array}$ \\
\hline Other Tool/Incentive & - Farm, Forest and Open Space Program & Talk to Tax Assessor \\
\hline Municipal Land Trust & - The Hopkinton Municipal Land Trust & $\begin{array}{l}\text { Newly established } \\
\text { The land trust has just } \\
\text { been granted } \$ 250,000 \\
\text { from the town budget }\end{array}$ \\
\hline Wetlands & & \\
\hline $\begin{array}{l}\text { Ension and Sediment } \\
\text { Control Plan }\end{array}$ & $\begin{array}{l}\text { Erosion and Sediment Control Plan } \\
\text { (required for all major subdivisions and } \\
\text { land developments as well as minor and } \\
\text { administrative subdivisions if deemed } \\
\text { necessary by planning board) } \\
\text { - (See also Development Plan Review } \\
\text { Ordinance) zo }\end{array}$ & $\begin{array}{l}\text { Bonded by the Town } \\
\text { Monitored by the Public } \\
\text { Works Department and } \\
\text { the Building Inspector }\end{array}$ \\
\hline
\end{tabular}




\section{Hopkinton Municipal Protections}

\begin{tabular}{|l|l|l|}
\hline Issue Area & Municipal Protection Measures & Implementation \\
\hline
\end{tabular}

\begin{tabular}{|c|c|c|}
\hline $\begin{array}{l}\text { Wetlands } \\
\text { (continued) }\end{array}$ & & \\
\hline $\begin{array}{l}\text { Land Unsuitable for } \\
\text { Development }\end{array}$ & $\begin{array}{l}\text { Freshwater wetlands are considered } \\
\text { "land unsuitable for development" }\end{array}$ & $\begin{array}{l}\text { Developers are required } \\
\text { to identify "land } \\
\text { unsuitable for } \\
\text { development" in Master } \\
\text { Plan (?) } \\
\text { Planner conducts on-site } \\
\text { analysis } \\
\text { Planner uses "constraints } \\
\text { maps" }\end{array}$ \\
\hline $\begin{array}{l}\text { Environmental } \\
\text { Analysis/Impact } \\
\text { Statement }\end{array}$ & $\begin{array}{l}\text { Impact Statement ( may be required if } \\
\text { there is reasonable expectation of a } \\
\text { significant negative environmental } \\
\text { impact on natural systems) }\end{array}$ & $\begin{array}{l}\text { Impact analysis is usually } \\
\text { done by the developers } \\
\text { engineer, however, the } \\
\text { town can and has brought } \\
\text { in outside opinion for } \\
\text { major projects at the } \\
\text { developers expense }\end{array}$ \\
\hline Lot Design Standards & $\begin{array}{l}\text { Lot Design Standards (easement may be } \\
\text { require if property is traversed by a water } \\
\text { course, drainage way, channel or stream, } \\
\text { there shall be provided a stormwater } \\
\text { easement or drainage right-of-way) }\end{array}$ & \\
\hline Site Design & $\begin{array}{l}\text { Site Design Standards (To the maximum } \\
\text { extent practicable, development shall be } \\
\text { located to preserve the natural features } \\
\text { of the site, to avoid areas of } \\
\text { environmental sensitivity, and to } \\
\text { minimize negative impacts and } \\
\text { alternation of natural features... Unique } \\
\text { and/or fragile areas, including freshwater } \\
\text { wetlands shall be preserved as } \\
\text { undeveloped open space or lot areas } \\
\text { where feasible) }\end{array}$ & $\begin{array}{l}\text { The Planning Board may } \\
\text { use the Cluster ordinance } \\
\text { to better protect the } \\
\text { natural features of the site } \\
\text { The Planner works with } \\
\text { the developer to heip } \\
\text { integrate the natural } \\
\text { features of the site at the } \\
\text { "Conceptual Plan" stage } \\
\text { of the development } \\
\text { process } \\
\text { See also "Land Unsuitable } \\
\text { for Development" } \\
\text { There is not universal } \\
\text { support for increased } \\
\text { setbacks from wetlands }\end{array}$ \\
\hline Site Plan Review & $\begin{array}{l}\text { Development Plan Review, Design } \\
\text { Standards (The development insofar as } \\
\text { practicable shall: result in minimal } \\
\text { degradation of unique or irreplaceable } \\
\text { land types and in minimum adverse } \\
\text { impact upon the critical areas such as } \\
\text { streams, wetlands...) zo }\end{array}$ & Strictly adhered to \\
\hline \multicolumn{3}{|l|}{ Performance Standards } \\
\hline Other Tool/Incentive & & \\
\hline
\end{tabular}




\begin{tabular}{|l|l|l|}
\hline Issue Area & Municipal Protection Measures & Implementation \\
\hline
\end{tabular}

\begin{tabular}{|c|c|c|}
\hline $\begin{array}{l}\text { Watercourses/ } \\
\text { Surface Waters }\end{array}$ & & \\
\hline Protection District & $\begin{array}{l}\text { Floodplain and Watercourse Protection } \\
\text { District zo }\end{array}$ & $\begin{array}{l}\text { Regulations are the same } \\
\text { as those found in DEM's } \\
\text { wetlands regulations, no } \\
\text { additional setback } \\
\text { requirements are included } \\
\text { in the town protection } \\
\text { district }\end{array}$ \\
\hline $\begin{array}{l}\text { Erosion and Sediment } \\
\text { Control Plan }\end{array}$ & $\begin{array}{l}\text { Erosion and Sediment Control Plan } \\
\text { (required for all major land } \\
\text { developments as well as minor and } \\
\text { administrative subdivisions if deemed } \\
\text { necessary by planning board) } \\
\text { - (See also Development Plan Review } \\
\text { Ordinance) zo }\end{array}$ & $\begin{array}{l}\text { Bonded by the Town } \\
\text { Monitored by the Public } \\
\text { Works Department and } \\
\text { the Building Inspector } \\
\text { Planner did not explain } \\
\text { why the regulations do } \\
\text { not apply to minor and } \\
\text { administrative } \\
\text { subdivisions }\end{array}$ \\
\hline Protection District & $\begin{array}{l}\text { - Floodplain and Watercourse Protection } \\
\text { District zo }\end{array}$ & Adhered to \\
\hline $\begin{array}{l}\text { Environmental } \\
\text { Analysis/Impact } \\
\text { Statement }\end{array}$ & $\begin{array}{l}\text { Impact Statement ( may be required if } \\
\text { there is reasonable expectation of a } \\
\text { significant negative environmental } \\
\text { impact on natural systems) }\end{array}$ & $\begin{array}{l}\text { Impact analysis is usually } \\
\text { done by the developers } \\
\text { engineer, however, the } \\
\text { town can and has brought } \\
\text { in outside opinion for } \\
\text { major projects at the } \\
\text { developers expense }\end{array}$ \\
\hline Site Design & $\begin{array}{l}\text { Lot Design Standards (easement may be } \\
\text { require if property is traversed by a water } \\
\text { course, drainage way, channel or stream, } \\
\text { there shall be provided a stormwater } \\
\text { easement or drainage right-of-way) }\end{array}$ & \\
\hline Site Plan Review & $\begin{array}{l}\text { Development Plan Review, Design } \\
\text { Standards (The development insofar as } \\
\text { practicable shall: result in minimal } \\
\text { degradation of unique or irreplaceable } \\
\text { land types and in minimum adverse } \\
\text { impact upon the critical areas such as } \\
\text { streams, wetlands...) zo }\end{array}$ & $>$ Strictly adhered to \\
\hline \multicolumn{3}{|l|}{ Performance Standards } \\
\hline Other & & \\
\hline
\end{tabular}




\begin{tabular}{|l|l|l|}
\hline Issue Area & Municipal Protection Measures & Implementation \\
\hline
\end{tabular}

\begin{tabular}{|c|c|c|}
\hline $\begin{array}{l}\text { Groundwater/ } \\
\text { Recharge Areas }\end{array}$ & & \\
\hline Protection District & & $\begin{array}{l}\text { Town is currently } \\
\text { working on adopting a } \\
\text { Groundwater and Aquifer } \\
\text { Protection Overlay } \\
\text { District } \\
\text { DEM is assisting the } \\
\text { town in developing that } \\
\text { ordinance. }\end{array}$ \\
\hline $\begin{array}{l}\text { Environmental } \\
\text { Analysis/Impact } \\
\text { Statement }\end{array}$ & $\begin{array}{l}\text { Impact Statement (may be required if } \\
\text { there is reasonable expectation of a } \\
\text { significant negative environmental } \\
\text { impact on natural systems) }\end{array}$ & $\begin{array}{l}\text { Impact analysis is usually } \\
\text { done by the developers } \\
\text { engineer, however, the } \\
\text { town can and has brought } \\
\text { in outside opinion for } \\
\text { major projects at the } \\
\text { developers expense } \\
\text { The Planner and Planning } \\
\text { Commission do not seem } \\
\text { to know what land lies } \\
\text { over the aquifer or its } \\
\text { recharge area. Therefore, } \\
\text { it is unlikely that an } \\
\text { Impact Analysis is often } \\
\text { required to protect } \\
\text { groundwater in } \\
\text { Hopkinton. }\end{array}$ \\
\hline Site Design & $\begin{array}{l}\text { Site Design standards (development shall } \\
\text { be laid out to avoid adversely affecting } \\
\text { ground water and aquifer recharge; to } \\
\text { reduce cut and fill; to avoid unnecessary } \\
\text { impervious cover; to prevent flooding) }\end{array}$ & $\begin{array}{l}\text { Based on my interview } \\
\text { with the Planner, it does } \\
\text { not seem likely that site } \\
\text { design standards are used } \\
\text { to protect groundwater. } \\
\text { The Planner and Planning } \\
\text { Commission do not seem } \\
\text { to know what land lies } \\
\text { over the aquifer or its } \\
\text { recharge area. }\end{array}$ \\
\hline Site Plan Review & $\begin{array}{l}\text { Development Plan Review, Design } \\
\text { Standards (The development insofar as } \\
\text { practicable shall result in minimal } \\
\text { degradation of unique or irreplaceable } \\
\text { land types and in minimum adverse } \\
\text { impact upon the critical areas such as } \\
\text { streams, wetlands, areas of aquifer } \\
\text { recharge and discharge... areas with a } \\
\text { high water table...) zo }\end{array}$ & \\
\hline Other & & \\
\hline
\end{tabular}




\begin{tabular}{|l|l|l|}
\hline Issue Area & Municipal Protection Measures & Implementation \\
\hline
\end{tabular}

\begin{tabular}{|c|c|c|}
\hline \multicolumn{3}{|l|}{ Floodplains } \\
\hline Protection District & $\begin{array}{l}\text { Floodplain and Watercourse Protection } \\
\text { District zo }\end{array}$ & $\begin{array}{l}\text { Regulations are the same } \\
\text { as those found in DEM's } \\
\text { wetlands regulations, no } \\
\text { additional setback } \\
\text { requirements are included } \\
\text { in the town protection } \\
\text { district }\end{array}$ \\
\hline $\begin{array}{l}\text { Land Unsuitable for } \\
\text { Development }\end{array}$ & $\begin{array}{l}\text { - Areas within a High Flood Danger Zone } \\
\text { are considered "land unsuitable for } \\
\text { development" }\end{array}$ & \\
\hline \multicolumn{3}{|l|}{$\begin{array}{l}\text { Environmental } \\
\text { Analysis/Impact } \\
\text { Statement }\end{array}$} \\
\hline Site Design & $\begin{array}{l}\text { - Site Design standards (lands in the flood } \\
\text { plain shall be preserved as undeveloped } \\
\text { open space where feasible) } \\
\text { Lot Design Standards (easement may be } \\
\text { require if property is traversed by a water } \\
\text { course, drainage way, channel or stream, } \\
\text { there shall be provided a stormwater } \\
\text { easement or drainage right-of-way) }\end{array}$ & \\
\hline Site Plan Review & $\begin{array}{l}\text { Development Plan Review, Ecological } \\
\text { Considerations (The development } \\
\text { insofar as practicable shall conform with } \\
\text { existing geological and topographical } \\
\text { features, to the end that the most } \\
\text { appropriate use of land is encouraged) zo }\end{array}$ & \\
\hline Performance Principles & & \\
\hline
\end{tabular}




\begin{tabular}{|l|l|l|}
\hline Issue Area & Municipal Protection Measures & Implementation \\
\hline
\end{tabular}

\begin{tabular}{|c|c|c|}
\hline \multicolumn{3}{|l|}{ Topography } \\
\hline $\begin{array}{l}\text { Erosion and Sediment } \\
\text { Control Plan }\end{array}$ & $\begin{array}{l}\text { Erosion and Sediment Control Plan } \\
\text { (required for all major land } \\
\text { developments as well as minor and } \\
\text { administrative subdivisions if deemed } \\
\text { necessary by planning board) } \\
\text { - (See also Development Plan Review } \\
\text { Ordinance) zo }\end{array}$ & $\begin{array}{l}\text { Bonded by the Town } \\
\text { Monitored by the Public } \\
\text { Works Department and } \\
\text { the Building Inspector } \\
\text { There is a general feeling } \\
\text { among developers that all } \\
\text { the good land has already } \\
\text { been developed. } \\
\text { Planner did not explain } \\
\text { why the regulations do } \\
\text { not apply to minor and } \\
\text { administrative } \\
\text { subdivisions }\end{array}$ \\
\hline $\begin{array}{l}\text { Land Unsuitable for } \\
\text { Development }\end{array}$ & $\begin{array}{l}\text { Steep slopes in excess of } 15 \% \text { are } \\
\text { considered "land unsuitable for } \\
\text { development" }\end{array}$ & \\
\hline \multicolumn{3}{|l|}{$\begin{array}{l}\text { Environmental } \\
\text { Analysis/Impact } \\
\text { Statement }\end{array}$} \\
\hline Site Design & $\begin{array}{l}\text { - Steep slopes in excess of } 15 \% \text { must be } \\
\text { preserved as open space pursuant to the } \\
\text { site design requirements zo }\end{array}$ & $\begin{array}{l}\text { The Planning Board may } \\
\text { use the Cluster ordinance } \\
\text { to better protect the } \\
\text { natural features of the site } \\
\text { The Planner works with } \\
\text { the developer to help } \\
\text { integtate the natural } \\
\text { features of the site at the } \\
\text { "Conceptual Plan" stage } \\
\text { of the development } \\
\text { process }\end{array}$ \\
\hline Site Plan Review & $\begin{array}{l}\text { Development Plan Review, Ecological } \\
\text { Considerations (The development } \\
\text { insofar as practicable shall: result in } \\
\text { minimal degradation of unique or } \\
\text { irreplaceable land types and in minimum } \\
\text { adverse impact upon the critical areas } \\
\text { such as... highly erodible soils; shall } \\
\text { conform with existing geological and } \\
\text { topographical features, to the end that } \\
\text { the most appropriate use of land is } \\
\text { encouraged) zo }\end{array}$ & \\
\hline
\end{tabular}




\begin{tabular}{|l|l|l|}
\hline Issue Area & Municipal Protection Measures & Implementation \\
\hline
\end{tabular}

\begin{tabular}{|c|c|c|}
\hline $\begin{array}{l}\text { Rare Species/ } \\
\text { Critical } \\
\text { Habitat }\end{array}$ & & \\
\hline \multicolumn{3}{|l|}{$\begin{array}{l}\text { Land Unsuitable for } \\
\text { Development }\end{array}$} \\
\hline $\begin{array}{l}\text { Environmental } \\
\text { Analysis/ Impact } \\
\text { Statement }\end{array}$ & $\begin{array}{l}\text { Impact State (may be required if there is } \\
\text { reasonable expectation of a significant } \\
\text { negative environmental impact on } \\
\text { natural systems) }\end{array}$ & $\begin{array}{l}\text { Impact analysis is } \\
\text { required if the site } \\
\text { includes habitat identified } \\
\text { on the Natural Heritage } \\
\text { GIS maps. }\end{array}$ \\
\hline Site Design & $\begin{array}{l}\text { - Site Design standards (habitats of } \\
\text { endangered wildlife, as identified on } \\
\text { applicable federal or state lists shall be } \\
\text { preserved as undeveloped open space } \\
\text { where feasible) }\end{array}$ & $\begin{array}{l}\text { "Limits of disturbance" } \\
\text { discussed throughout the } \\
\text { application process. } \\
\text { "No Cut Zones" can be } \\
\text { negotiated for with } \\
\text { developers. }\end{array}$ \\
\hline Site Plan Review & $\begin{array}{l}\text { Development Plan Review, Design } \\
\text { Standards (The development insofar as } \\
\text { practicable shall result in minimal } \\
\text { degradation of unique or irreplaceable } \\
\text { land types and in minimum adverse } \\
\text { impact upon the critical areas such as... } \\
\text { mature stands of vegetation, and } \\
\text { extraordinary wildlife nesting, feeding, or } \\
\text { breeding grounds) zo }\end{array}$ & $>$ Adhered to \\
\hline Other & & \\
\hline
\end{tabular}




\begin{tabular}{|l|l|l|}
\hline Issue Area & Municipal Protection Measures & Implementation \\
\hline
\end{tabular}

\begin{tabular}{|c|c|c|}
\hline \multicolumn{3}{|l|}{$\begin{array}{l}\text { Trees/ } \\
\text { Woodlands }\end{array}$} \\
\hline $\begin{array}{l}\text { Erosion and Sediment } \\
\text { Control Plan }\end{array}$ & $\begin{array}{l}\text { Erosion and Sediment Control Plan, } \\
\text { Performance Principles (Trees and other } \\
\text { existing vegetation shall be retained whenever } \\
\text { feasible; the area within the dripline shall be } \\
\text { fenced or roped off to protect tress from } \\
\text { construction equipment) } \\
\text { - (See also Development Plan Review) zo }\end{array}$ & $\begin{array}{l}\text { Addressed within lot and } \\
\text { site design standards. } \\
\text { "No Cut Zones" can be } \\
\text { negotiated for with } \\
\text { developers. }\end{array}$ \\
\hline \multicolumn{3}{|l|}{$\begin{array}{l}\text { Environmental } \\
\text { Analysis/ } \\
\text { Impact Statement }\end{array}$} \\
\hline Site Design & $\begin{array}{l}\text { - Site Design standards (significant trees or } \\
\text { stands of trees, or other vegetative } \\
\text { species that are rare to the area or are of } \\
\text { particular horticultural or landscape value } \\
\text { shall be preserved as undeveloped open } \\
\text { space where feasible) } \\
\text { Lot Development Standards (for } \\
\text { administrative subdivisions may require } \\
\text { preservation of historic, unique natural } \\
\text { features such as trees or stone walls) }\end{array}$ & $\begin{array}{l}\text { "No Cut Zones" can be } \\
\text { negotiated for with } \\
\text { developers. }\end{array}$ \\
\hline Site Plan Review & $\begin{array}{l}\text { Development Plan Review, Ecological } \\
\text { Considerations (The development } \\
\text { insofar as practicable shall result in } \\
\text { minimal degradation of unique or } \\
\text { irreplaceable land types and in minimum } \\
\text { adverse impact upon the critical areas } \\
\text { such as... mature stands of vegetation, } \\
\text { and extraordinary wildlife nesting, } \\
\text { feeding, or breeding grounds) zo } \\
\text { Development Plan Review, Landscape } \\
\text { (The landscape shall be preserved in its } \\
\text { natural state insofar as practicable by } \\
\text { minimizing tree removal, disturbance of } \\
\text { the soil, and retaining the existing } \\
\text { vegetation during and after } \\
\text { construction...) zo }\end{array}$ & $>$ Adhered to \\
\hline Other & $\begin{array}{l}\text { A } 100 \text { foot buffer is required around the } \\
\text { perimeter of a residential cluster } \\
\text { development }\end{array}$ & $\begin{array}{l}\text { No longer mandated. The } \\
\text { town prefers more } \\
\text { flexibility in siting open } \\
\text { space in a cluster design. }\end{array}$ \\
\hline
\end{tabular}




\section{TOWN OF RICHMOND PROFILE}

\section{Summary}

Richmond's planning capacity appears to be adequate, based on the criteria used in this study. Support for land conservation and natural resource protection is very high among town officials. Richmond is one of only two towns in the study area with mandatory residential cluster development. The Town currently holds 200 acres in easements through the open space provisions in its cluster ordinance. The Town has also recently revised its subdivision and land development regulations to strengthen natural resource protection in the design of sites.

Many of the Town's comprehensive plan objectives have been adopted or implement in some manner. The Town has an agricultural overlay district that includes density bonuses for creating farm lots in the subdivision design. The Town's new land trust is working with The Nature Conservancy to develop a priority list for land acquisition.

\section{Planning Department}

Richmond employs one half-time planner (who has a background in environmental management). The Town does not possess in-house GIS capacity. However, the planning board frequently requires an extensive environmental impact statement for major subdivisions. The planning board recently adopted a mandatory site analysis for all major subdivisions (and for minor subdivisions on a case-by-case basis).

The Town's planning board is very experienced and committed to land conservation and natural resource protection. In particular, planning officials make every attempt to protect the rural character of the Town. The planning board considers contiguous open space parcels when reviewing site design. Its intent is to create linked greenspaces throughout the Town. 
Planning capacity limitations mentioned during the interview for this study include, parcel data mapping and in-house GIS capacity.

\section{Comprehensive Plan Objectives}

Richmond's comprehensive plan objectives provide detailed guidance for strengthening the Town's land conservation and natural resource protection efforts. The Town's adoption of mandatory cluster for all major subdivisions acts as a proxy for many of the plan's objectives. For example, the planning board uses the flexibility of the ordinance to maintain large vegetative buffer zones for water bodies and wetlands and to create linked greenspaces throughout the Town. The Town's new land trust will help to implement a number of the plan's recommended land conservation strategies.

\section{Site Analysis}

The planning board relies heavily on its authority to require an EIS from developers. An engineer is retained by the Town for this purpose. The planning board also requires a mandatory site analysis for all major subdivisions (and for minor subdivisions on a case-by-case basis) to ensure strict environmental considerations in the design of the site.

\section{Zoning and Subdivision Regulations}

\section{Zoning Ordinances}

- Farmland Zoning-The Town has adopted an agricultural overlay district and density bonuses for the creation of farm lots in the design of the subdivision.

- Residential Cluster Development-Cluster is required for all major subdivisions ( $40 \%$ of the gross area must be preserved as open space; no more than $25 \%$ of the minimum open space can be land unsuitable for development)

- Large Lot Residential Zoning-R-2 and R-3 low density residential districts.

- Overlay Districts-Agricultural Overlay District; Aquifer Protection Overlay District

- Site Plan Review-The Town maintains strict environmental standards in its site plan review ordinance.

- Performance Standards-none 


\section{Subdivision and Land Development Regulations}

- Land Unsuitable for Development-Shall be deducted from the buildable acreage of the parcel--freshwater wetlands, except that area of perimeter wetland within 50 feet of the edge of any bog, marsh, swamp or pond; or any applicable 100 foot or 200 foot riverbank wetlands; areas within a High Flood Danger zone; land within any publicly or privately held easement on which above-ground utilities, including but not limited to electrical transmission lines, are constructed.

- Environmental Analysis - The planning board has the authority to require an EIS. The board requires an EIS for most major subdivisions. The Town retains an engineer for this purpose.

- Erosion and Sediment Control-An erosion and sediment control plan is required for all major subdivisions and land developments (and for minor subdivisions on a case-by-case basis). The Town is very strict about evaluating and monitoring plans.

- Site Design Standards-The Town has high site design standards, and mandates a site analysis for major subdivisions. The Town's mandatory cluster design for major subdivisions provides a great deal of flexibility in guiding development away from environmentally sensitive areas of the site. 


\section{Richmond Comprehensive Plan Matrix}

\begin{tabular}{|l|l|l|}
\hline Issue Area & $\begin{array}{l}\text { Comprehensive Planning } \\
\text { Objective }\end{array}$ & Implementation \\
\hline
\end{tabular}

\begin{tabular}{|c|c|c|c|}
\hline $\begin{array}{l}\text { Farmland } \\
\text { Preservation }\end{array}$ & & & \\
\hline & $\begin{array}{l}\text { Designate Agricultural } \\
\text { Preservation Districts and } \\
\text { propose zoning ordinance } \\
\text { revisions to the Town Council } \\
\text { in order to sustain agricultural } \\
\text { operations, preserve open } \\
\text { spaces and maintain } \\
\text { groundwater recharge areas }\end{array}$ & & Adopted "Agricultural Overlay District" \\
\hline \multicolumn{4}{|l|}{$\begin{array}{l}\text { Open Space } \\
\text { Zoning }\end{array}$} \\
\hline \multicolumn{4}{|l|}{$\begin{array}{l}\text { Open Space } \\
\text { Preservation }\end{array}$} \\
\hline & $\begin{array}{l}\text { Identify open space corridors, } \\
\text { determine compatible land } \\
\text { uses, and develop land } \\
\text { acquisition and management } \\
\text { programs }\end{array}$ & & $\begin{array}{l}\text { The new land trust and TNC are } \\
\text { creating an acquisitions priority list for } \\
\text { open space (they are conducting a } \\
\text { townwide survey of what to protect; } \\
\text { also, they are focusing on small } \\
\text { watersheds) } \\
\text { Informally through clustering } \\
\text { provisions }\end{array}$ \\
\hline & $\begin{array}{l}\text { Create a Land Trust for the } \\
\text { purpose of establishing } \\
\text { management areas, parks and } \\
\text { open spaces }\end{array}$ & & Adopted \\
\hline & $\begin{array}{l}\text { Establish a greenway network } \\
\text { connecting the major } \\
\text { development and natural areas } \\
\text { of the town }\end{array}$ & & $\begin{array}{l}\text { Informally through clustering } \\
\text { provisions and site analysis }\end{array}$ \\
\hline & $\begin{array}{l}\text { Minimum lot sizes will be } \\
\text { increased in areas of } \\
\text { environmental sensitivity within } \\
\text { the flexibility of cluster and } \\
\text { residential compound } \\
\text { regulations }\end{array}$ & & $\begin{array}{l}\text { In } 1990 \text { the town adopted } 3 \text { acre zoning } \\
\text { to protect its aquifer recharge area-- } \\
\text { encompasses a third of the town. }\end{array}$ \\
\hline & $\begin{array}{l}\text { - Encourage a network of } \\
\text { contiguous greenbelts while } \\
\text { reviewing development } \\
\text { proposals } \\
\end{array}$ & & $\begin{array}{l}\text { The Planning Board considers } \\
\text { contiguous open spaces when reviewing } \\
\text { site design for cluster developments. }\end{array}$ \\
\hline
\end{tabular}




\section{Richmond Comprehensive Plan Matrix}

\begin{tabular}{|l|l|l|}
\hline Issue Area & $\begin{array}{l}\text { Comprehensive Planning } \\
\text { Objective }\end{array}$ & Implementation \\
\hline
\end{tabular}

\begin{tabular}{|c|c|c|}
\hline $\begin{array}{l}\text { Natural } \\
\text { Resource } \\
\text { Protection }\end{array}$ & & \\
\hline \multicolumn{3}{|l|}{ Wetlands } \\
\hline & $\begin{array}{l}\text { Prepare wetlands management } \\
\text { plans and require best } \\
\text { management practices in order } \\
\text { to control non-point source } \\
\text { contamination of groundwater }\end{array}$ & $\begin{array}{l}\text { Planner feels that Site Design Standards } \\
\text { and Development Plan Review } \\
\text { incorporate "best management } \\
\text { practices" for wetlands protection }\end{array}$ \\
\hline \multicolumn{3}{|l|}{$\begin{array}{l}\text { Watercourse/ } \\
\text { Surface Water }\end{array}$} \\
\hline & $\begin{array}{l}\text { Where practical, promote } 300 \\
\text { foot wide buffer zones along } \\
\text { major rivers to be 'non-clear' } \\
\text { zones restricted by } \\
\text { conservation easements }\end{array}$ & $>$ Mandatory Cluster acts as a proxy. \\
\hline & $\begin{array}{l}\text { Establish an ISDS setback } \\
\text { requirement from the rainy } \\
\text { season flow line of streams or } \\
\text { from the high water mark of } \\
\text { standing water bodies }\end{array}$ & $>$ Relies on state regulations \\
\hline & $\begin{array}{l}\text { A Trout Stream Corridor is } \\
\text { recommended for the } \\
\text { protection of the Wood River }\end{array}$ & $>$ Not adopted \\
\hline & $\begin{array}{l}\text { It is recommended that no new } \\
\text { development occur within } 200 \\
\text { feet of the Wood River }\end{array}$ & Relies on state regulations \\
\hline & $\begin{array}{l}\text { Determine the feasibility of } \\
\text { establishing a program for } \\
\text { monitoring the quality of } \\
\text { ground and surface waters }\end{array}$ & $>$ Not adopted \\
\hline
\end{tabular}




\section{Richmond Comprehensive Plan Matrix}

\begin{tabular}{|l|l|l|}
\hline Issue Area & $\begin{array}{l}\text { Comprehensive Planning } \\
\text { Objective }\end{array}$ & Implementation \\
\hline
\end{tabular}

\begin{tabular}{|c|c|c|}
\hline $\begin{array}{l}\text { Groundwate/ } \\
\text { Recharge } \\
\text { Areas }\end{array}$ & & \\
\hline & $\begin{array}{l}\text { Designate Agricultural } \\
\text { Preservation Districts and } \\
\text { propose zoning ordinance } \\
\text { revisions in order to sustain } \\
\text { agricultural operations, preserve } \\
\text { open spaces and maintain } \\
\text { groundwater recharge areas }\end{array}$ & Adopted \\
\hline & $\begin{array}{l}\text { Prepare wetlands management } \\
\text { plans and require best } \\
\text { management practices in order } \\
\text { to control non-point source } \\
\text { contamination of groundwater }\end{array}$ & $\begin{array}{l}\text { Site Design Standards and } \\
\text { Development Plan Review }\end{array}$ \\
\hline & $\begin{array}{l}\text { Determine the feasibility of } \\
\text { establishing a program for } \\
\text { monitoring the quality of } \\
\text { ground and surface waters }\end{array}$ & $>$ Not Adopted \\
\hline Floodplains & & \\
\hline $\begin{array}{l}\text { Coastal } \\
\text { Features }\end{array}$ & & \\
\hline Topography & & \\
\hline $\begin{array}{l}\text { Rare } \\
\text { Species/ } \\
\text { Critical } \\
\text { Habitat }\end{array}$ & & \\
\hline & $\begin{array}{l}\text { Identify rare native plant } \\
\text { communities, determine } \\
\text { compatible land usage, and } \\
\text { develop land acquisition and } \\
\text { management programs }\end{array}$ & $>\quad$ Not adopted \\
\hline $\begin{array}{l}\text { Trees/ } \\
\text { Woodlands }\end{array}$ & & \\
\hline
\end{tabular}




\section{Richmond Comprehensive Plan Matrix}

\begin{tabular}{|l|l|l|}
\hline Issue Area & $\begin{array}{l}\text { Comprehensive Planning } \\
\text { Objective }\end{array}$ & Implementation \\
\hline
\end{tabular}

\begin{tabular}{|c|c|c|}
\hline $\begin{array}{l}\text { Cultural and } \\
\text { Historic } \\
\text { Resources }\end{array}$ & & \\
\hline \multicolumn{3}{|l|}{$\begin{array}{l}\text { Village/Rural } \\
\text { Character }\end{array}$} \\
\hline & $\begin{array}{l}\text { Take the necessary steps to } \\
\text { amend its ordinances and } \\
\text { regulations for the purposes of } \\
\text { creating Heritage Districts }\end{array}$ & $\begin{array}{l}\text { Received CBG funding with } \\
\text { Charlestown to protect Shannock } \\
\text { Village }\end{array}$ \\
\hline & $\begin{array}{l}\text { - Study the preparation of village } \\
\text { plans in order to promote small } \\
\text { businesses, tourism, and } \\
\text { agricultural operations }\end{array}$ & $>$ On-going? \\
\hline & $\begin{array}{l}\text { Concentrate major } \\
\text { developments and community } \\
\text { facilities in the established } \\
\text { villages }\end{array}$ & $\begin{array}{l}\text { Created a } 1000 \text { acre Planned } \\
\text { Development District to preserve the } \\
\text { rural characteristics of the town }\end{array}$ \\
\hline & $\begin{array}{l}\text { Maintain a list and map of } \\
\text { environmentally sensitive areas } \\
\text { and sites that are of historical, } \\
\text { cultural or archaeological value } \\
\text { to the town }\end{array}$ & $>$ The Comprehensive Plan \\
\hline & $\begin{array}{l}\text { Relate the extent of } \\
\text { development to the capacity of } \\
\text { public facilities and services }\end{array}$ & $\begin{array}{l}\text { The town has adopted impact fees and } \\
\text { requires the phasing of development } \\
\text { Subdivision and land development } \\
\text { proposals are sent to all other town } \\
\text { departments for comment. }\end{array}$ \\
\hline & $\begin{array}{l}\text { - Prepare plans for the extension } \\
\text { of the water distribution system } \\
\text { in order to promote the orderly } \\
\text { development of the Hope } \\
\text { Valley-Wyoming Area }\end{array}$ & $\begin{array}{l}\text { Water distribution system was extended } \\
\text { into Hope Valley. }\end{array}$ \\
\hline & $\begin{array}{l}\text { - Regulate any significant } \\
\text { construction, ground disturbing } \\
\text { activity or alternation of } \\
\text { vegetation within fifty ( } 50 \text { ) feet } \\
\text { of a Historic District boundary }\end{array}$ & $>$ \\
\hline & $\begin{array}{l}\text { Design development sites that } \\
\text { are compatible with } \\
\text { surrounding land uses, and } \\
\text { subject to performance } \\
\text { standards }\end{array}$ & Adopted \\
\hline
\end{tabular}


Richmond Comprehensive Plan Matrix

\begin{tabular}{|l|l|l|}
\hline Issue Area & $\begin{array}{l}\text { Comprehensive Planning } \\
\text { Objective }\end{array}$ & Implementation \\
\hline
\end{tabular}

\begin{tabular}{|c|c|}
\hline $\begin{array}{l}\text { Village/Rural } \\
\text { Character } \\
\text { (continued) }\end{array}$ & \\
\hline & $\begin{array}{l}\text { Collaborate with the planning } \\
\text { boards of the neighboring } \\
\text { towns in order to maintain the } \\
\text { vitality and character of mill } \\
\text { villages }\end{array}$ \\
\hline & $\begin{array}{l}\text { Designate historic and scenic } \\
\text { roadways and protect the } \\
\text { rights-of-way }\end{array}$ \\
\hline
\end{tabular}




\section{Richmond Municipal Protections}

\begin{tabular}{|l|l|l|}
\hline $\begin{array}{l}\text { Natural } \\
\text { Resource } \\
\text { Protection }\end{array}$ & Municipal Protection Measure & Implementation \\
\hline
\end{tabular}

\begin{tabular}{|c|c|c|}
\hline $\begin{array}{l}\text { Land } \\
\text { Conservation }\end{array}$ & & \\
\hline \multicolumn{3}{|l|}{$\begin{array}{l}\text { Farmland } \\
\text { Preservation }\end{array}$} \\
\hline Zoning Regulations & $\begin{array}{l}\text { Agricultural Overlay District (single family } \\
\text { development is permitted by right: a } \\
\text { minimum of } 50 \text { gross acres is required for } \\
\text { both residential cluster developments and } \\
\text { residential compounds) zo }\end{array}$ & $\begin{array}{l}\text { No applications as of yet } \\
\text { There is a } 5 \text { acre density } \\
\text { rule and density bonuses } \\
\text { for creating farm lots. } \\
\text { The Planning Board is } \\
\text { very concerned with } \\
\text { maintaining rural } \\
\text { character. }\end{array}$ \\
\hline Site Design & $\begin{array}{l}\text { Site Design Standards (call for agricultural } \\
\text { lands to be preserved as undeveloped open } \\
\text { space or lot area) } \\
\text { Criteria for Review for } 2 \text { lot subdivision } \\
\text { (Planning board shall maximize } \\
\text { preservation of agricultural lands and Prime } \\
\text { Farmland) }\end{array}$ & \\
\hline \multicolumn{3}{|l|}{$\begin{array}{l}\text { Open Space } \\
\text { Zoning }\end{array}$} \\
\hline & - No & \\
\hline \multicolumn{3}{|l|}{$\begin{array}{l}\text { Open Space } \\
\text { Preservation }\end{array}$} \\
\hline $\begin{array}{l}\text { Cluster } \\
\text { Development, } \\
\text { Residential } \\
\text { Compounds, Large } \\
\text { Lot Zoning }\end{array}$ & $\begin{array}{l}\text { Cluster required for all major subdivisions } \\
\text { ( } 40 \% \text { of the gross area must be preserved } \\
\text { as open space; no more than } 25 \% \text { of the } \\
\text { minimum open space can be land } \\
\text { unsuitable for development) zo }\end{array}$ & $\begin{array}{l}\text { The town has about } 200 \\
\text { acres in easements through } \\
\text { cluster provisions. } \\
\text { Site analysis takes into } \\
\text { consideration adjacent lands } \\
\text { to encourage continuous } \\
\text { greenways linking } \\
\text { subdivisions. } \\
\end{array}$ \\
\hline $\begin{array}{l}\text { Land Unsuitable } \\
\text { for Development }\end{array}$ & $\begin{array}{l}\text { - Land Unsuitable for Development (is } \\
\text { deducted from the buildable acreage of the } \\
\text { parcel--freshwater wetlands, except that } \\
\text { area of perimeter wetland within } 50 \text { feet of } \\
\text { the edge of any bog, marsh, swamp or } \\
\text { pond; or any applicable } 100 \text { foot or } 200 \\
\text { foot riverbank wetlands; areas within a } \\
\text { High Flood Danger zone; land within any } \\
\text { publicly or privately held easement on } \\
\text { which above-ground utilities, including but } \\
\text { not limited to electrical transmission lines, } \\
\text { are constructed) }\end{array}$ & \\
\hline
\end{tabular}




\section{Richmond Municipal Protections}

\begin{tabular}{|l|l|l|}
\hline $\begin{array}{l}\text { Natural } \\
\text { Resource } \\
\text { Protection }\end{array}$ & Municipal Protection Measure & Implementation \\
\hline
\end{tabular}

\begin{tabular}{|c|c|c|}
\hline $\begin{array}{l}\text { Open Space } \\
\text { Preservation } \\
\text { (continued) }\end{array}$ & & \\
\hline $\begin{array}{l}\text { Dedication of Land } \\
\text { for Public Purposes }\end{array}$ & $\begin{array}{l}\text { Dedication of Land for Public Purposes } \\
\text { (land dedication, payment in lieu or both } \\
\text { are required; amount of land to be } \\
\text { dedicated is } .01 \text { acres/per person) }\end{array}$ & Primarily "fee in lieu of" \\
\hline Site Design & & $\begin{array}{l}\text { See Cluster } \\
\text { The Planning Board is } \\
\text { opposed to all street front } \\
\text { development. }\end{array}$ \\
\hline $\begin{array}{l}\text { Natural } \\
\text { Resource } \\
\text { Protection } \\
\end{array}$ & & \\
\hline Wetlands & & \\
\hline $\begin{array}{l}\text { Erosion and } \\
\text { Sediment Control } \\
\text { Plan }\end{array}$ & $\begin{array}{l}\text { Erosion and Sediment Control Plan } \\
\text { (required for all major subdivisions and } \\
\text { land developments as well as for minor or } \\
\text { administrative subdivisions if deemed } \\
\text { necessary by the Planning Board) }\end{array}$ & $\begin{array}{l}\text { Not a separate plan (?) } \\
\text { There are looks of } \\
\text { watchdogs in town to insure } \\
\text { compliance. } \\
\text { Relies on the engineer to } \\
\text { work considerations into } \\
\text { site plan. } \\
\text { Routine inspections--eight } \\
\text { or nine times during } \\
\text { development project }\end{array}$ \\
\hline Setbacks & & $>$ Same as State regulations \\
\hline $\begin{array}{l}\text { Land Unsuitable } \\
\text { for Development }\end{array}$ & $\begin{array}{l}\text { - Freshwater wetlands are considered "land } \\
\text { unsuitable for development" }\end{array}$ & \\
\hline $\begin{array}{l}\text { Environmental } \\
\text { Analysis/Impact } \\
\text { Analysis }\end{array}$ & $\begin{array}{l}\text { - An EIS may be required (by authority of } \\
\text { the Planning Board) }\end{array}$ & $\begin{array}{l}\text { Required for most major } \\
\text { subdivision and all land } \\
\text { developments. } \\
\text { Developer must used the } \\
\text { town's engineer (kept on } \\
\text { retainer) }\end{array}$ \\
\hline Site Design & $\begin{array}{l}\text { Site Design Standards (call for unique } \\
\text { and/or fragile areas, including freshwater } \\
\text { wetlands to be preserved as undeveloped } \\
\text { open space or lot area) }\end{array}$ & $\begin{array}{l}\text { The Planning Board walks } \\
\text { the site to identify } \\
\text { constraints. } \\
\text { Cluster provisions provide } \\
\text { extra buffering for wetlands }\end{array}$ \\
\hline Site Plan Reviezn & $\begin{array}{l}\text { Development Plan Review Standards (calls } \\
\text { for minimal adverse impact upon critical } \\
\text { areas; natural features of land must be } \\
\text { shown on the site plan) zo }\end{array}$ & $>$ Strictly adhered to. \\
\hline $\begin{array}{l}\text { Performance } \\
\text { Standards }\end{array}$ & & \\
\hline
\end{tabular}




\section{Richmond Municipal Protections}

\begin{tabular}{|l|l|l|}
\hline $\begin{array}{l}\text { Natural } \\
\text { Resource } \\
\text { Protection }\end{array}$ & Municipal Protection Measure & Implementation \\
\hline
\end{tabular}

\begin{tabular}{|c|c|c|}
\hline $\begin{array}{l}\text { Watercourses/ } \\
\text { Surface Waters }\end{array}$ & & \\
\hline $\begin{array}{l}\text { Erosion and } \\
\text { Sediment Control } \\
\text { Plan }\end{array}$ & $\begin{array}{l}\text { Erosion and Sediment Control Plan } \\
\text { (required for all major subdivisions and } \\
\text { land developments as well as for minor or } \\
\text { administrative subdivisions if deemed } \\
\text { necessary by the Planning Board) }\end{array}$ & $\begin{array}{l}\text { Not a separate plan (?) } \\
\text { Relies on the engineer to } \\
\text { work considerations into } \\
\text { site plan. } \\
\text { Bonds if after final approval } \\
\text { (what does this mean?) } \\
>\quad \begin{array}{l}\text { Routine inspections--eight } \\
\text { or nine times during } \\
\text { development project }\end{array} \\
>\quad \begin{array}{l}\text { There are looks of } \\
\text { watchdogs in town to insure } \\
\text { compliance. }\end{array} \\
\end{array}$ \\
\hline \multicolumn{3}{|l|}{ Protection District } \\
\hline Setbacks & $\begin{array}{l}50 \text { foot Sewage Disposal Facility setback } \\
\text { (from any waterbody, pond, stream, brook } \\
\text { or river) zo }\end{array}$ & $>$ Reinforces State Regulations \\
\hline Site Design & & $\begin{array}{l}\begin{array}{l}\text { Cluster provisions provide } \\
\text { extra buffering for all } \\
\text { wetlands. }\end{array} \\
\end{array}$ \\
\hline Site Plan Review & $\begin{array}{l}\text { Site Plan Review, Standards--required for } \\
\text { all nonresidential activities (measures shall } \\
\text { conform to the minimum standards of the } \\
1993 \text { State of RI Stormwater Manual) zo }\end{array}$ & $>$ Strictly adhered to. \\
\hline $\begin{array}{l}\text { Performance } \\
\text { Standards }\end{array}$ & & $D$ \\
\hline Other & $\begin{array}{l}\text { Drainage Plan requirements (must leave } \\
\text { existing watercourses open, unless approval } \\
\text { to enclose is granted by the Planning } \\
\text { Board) }\end{array}$ & Standard requirements. \\
\hline
\end{tabular}


Richmond Municipal Protections

\begin{tabular}{|l|l|l|}
\hline $\begin{array}{l}\text { Natural } \\
\text { Resource } \\
\text { Protection }\end{array}$ & Municipal Protection Measure & Implementation \\
\hline
\end{tabular}

\begin{tabular}{|c|c|c|}
\hline \multicolumn{3}{|l|}{$\begin{array}{l}\text { Groundwater/ } \\
\text { Recharge Areas }\end{array}$} \\
\hline Protection District & - Aquifer Protection District zo & $\begin{array}{l}\text { The ordinance was written } \\
\text { in the } 1980 \mathrm{~s} \text {. } \\
\text { Very simple, covers a small } \\
\text { geographic area. }\end{array}$ \\
\hline $\begin{array}{l}\text { Environmental } \\
\text { Analysis/Impact } \\
\text { Statement }\end{array}$ & $\begin{array}{l}\text { EIS (required for most major subdivisions } \\
\text { and all major land developments or by } \\
\text { request of Planning Board) If required } \\
\text { must assess the short-term and long-term } \\
\text { impacts to groundwater. }\end{array}$ & $\begin{array}{l}\text { Developer must use the } \\
\text { town's engineer (kept on } \\
\text { retainer). }\end{array}$ \\
\hline \multicolumn{3}{|l|}{ Setbackes } \\
\hline Site Design & $\begin{array}{l}\text { Site Design Standards (calls for } \\
\text { development to be laid out to avoid } \\
\text { adversely affecting groundwater and } \\
\text { aquifer recharge) }\end{array}$ & $>$ Adhered to \\
\hline Site Plan Review & $\begin{array}{l}\text { Development Plan Review (standards for } \\
\text { ecological protection of areas of aquifer } \\
\text { recharge and discharge) zo }\end{array}$ & $>$ Adhered to \\
\hline Other & $\begin{array}{l}\text { - Residential } 3 \text { Acre Zoning District } \\
\text { (designation is intended to protect } \\
\text { groundwater) zo } \\
\text { Special Flood Hazard Areas (Regulations } \\
\text { are intended to minimize hazards to } \\
\text { persons and damage to property from } \\
\text { inland and tidal flooding, to protect } \\
\text { floodways from encroachment, and to } \\
\text { maintain the capacity of floodplains to } \\
\text { retain and carry off floodwaters) zo } \\
\end{array}$ & $\begin{array}{l}\text { Along with mandatory } \\
\text { cluster }\end{array}$ \\
\hline
\end{tabular}


Richmond Municipal Protections

\begin{tabular}{|l|l|l|}
\hline $\begin{array}{l}\text { Natural } \\
\text { Resource } \\
\text { Protection }\end{array}$ & Municipal Protection Measure & Implementation \\
\hline
\end{tabular}

\begin{tabular}{|c|c|c|}
\hline \multicolumn{3}{|l|}{ Floodplains } \\
\hline Protection District & $\begin{array}{l}\text { - Special Flood Hazard Areas (Regulations } \\
\text { are intended to minimize hazards to } \\
\text { persons and damage to property from } \\
\text { inland and tidal flooding, to protect } \\
\text { floodways from encroachment, and to } \\
\text { maintain the capacity of floodplains to } \\
\text { retain and carry off floodwaters) zo }\end{array}$ & $>$ \\
\hline $\begin{array}{l}\text { Land Unsuitable } \\
\text { for Development }\end{array}$ & $\begin{array}{l}\text { Areas within a High Flood Danger Zone } \\
\text { are considered "land unsuitable for } \\
\text { development" }\end{array}$ & $>$ \\
\hline $\begin{array}{l}\text { Environmental } \\
\text { Analysis/Impact } \\
\text { Statement }\end{array}$ & & $>$ \\
\hline \multicolumn{3}{|l|}{ Setbacks } \\
\hline Site Design & $\begin{array}{l}\text { - Site Design Standards (call for the } \\
\text { protection of lands in the flood plain as } \\
\text { undeveloped open space) }\end{array}$ & \\
\hline \multicolumn{3}{|l|}{ Site Plan Revien } \\
\hline \multicolumn{3}{|l|}{ Other } \\
\hline \multicolumn{3}{|l|}{ Topography } \\
\hline \multicolumn{3}{|l|}{$\begin{array}{l}\text { Erosion and } \\
\text { Sediment Control } \\
\text { Plan }\end{array}$} \\
\hline \multicolumn{3}{|l|}{$\begin{array}{l}\text { Land Unsuitable } \\
\text { for Development }\end{array}$} \\
\hline \multicolumn{3}{|l|}{ Site Design } \\
\hline Site Plan Review & $\begin{array}{l}\text { Development Plan Review, Ecological } \\
\text { Considerations (calls for minimal adverse } \\
\text { impact upon critical areas such as steep } \\
\text { slopes, highly erodible soils, areas with a } \\
\text { high water table...)natural features of land } \\
\text { must be shown on the site plan) zo }\end{array}$ & $>$ Adhered to \\
\hline
\end{tabular}




\section{Richmond Municipal Protections}

\begin{tabular}{|l|l|l|}
\hline $\begin{array}{l}\text { Natural } \\
\text { Resource } \\
\text { Protection }\end{array}$ & Municipal Protection Measure & Implementation \\
\hline
\end{tabular}

\begin{tabular}{|c|c|c|}
\hline $\begin{array}{l}\text { Rare Species/ } \\
\text { Critical Habitat }\end{array}$ & & \\
\hline \multicolumn{3}{|l|}{ Protection District } \\
\hline $\begin{array}{l}\text { Environmental } \\
\text { Analysis/Impact } \\
\text { Statement }\end{array}$ & $\begin{array}{l}\text { EIS maybe required (including an } \\
\text { assessment of short and long term } \\
\text { environmental impacts on natural heritage } \\
\text { areas and wildlife) }\end{array}$ & $\begin{array}{l}\text { Required for most major } \\
\text { subdivisions and all land } \\
\text { developments }\end{array}$ \\
\hline \multicolumn{3}{|l|}{ Setbackes } \\
\hline Site Design & $\begin{array}{l}\text { - Site Design Standards (require habitats of } \\
\text { endangered wildlife to be preserved as } \\
\text { undeveloped open space or lot area) }\end{array}$ & $\begin{array}{l}\text { Through Clustering } \\
\text { Provisions }\end{array}$ \\
\hline Site Plan Revien & $\begin{array}{l}\text { Development Plan Review, Ecological } \\
\text { Considerations (standards for ecological } \\
\text { protection of unique or irreplaceable land } \\
\text { types such as extraordinary wildlife nesting, } \\
\text { feeding or breeding grounds) zo }\end{array}$ & Adhered to \\
\hline \multicolumn{3}{|l|}{$\begin{array}{l}\text { Trees/ } \\
\text { Woodlands }\end{array}$} \\
\hline $\begin{array}{l}\text { Erosion and } \\
\text { Sediment Control } \\
\text { Plan }\end{array}$ & $\begin{array}{l}\text { Soil Erosion and Sediment Control, } \\
\text { Performance Principles (seeks to retain trees } \\
\text { and other exiting vegetation whenever feasible, } \\
\text { to protect them during construction and restore } \\
\text { all areas damaged during construction) }\end{array}$ & Adhered to \\
\hline Site Design & $\begin{array}{l}\text { - Site Design Standards (calls for the protection } \\
\text { of significant trees or stands of trees, or other } \\
\text { vegetative species that are rare to the area or of } \\
\text { particular horticultural or landscape value) }\end{array}$ & \\
\hline Site Plan Review & $\begin{array}{l}\text { Development Plan Review (The landscape shall } \\
\text { be preserved in its natural state, insofar as } \\
\text { environmentally desirable, by minimizing tree } \\
\text { and soil removal) zo }\end{array}$ & $>$ Adhered to \\
\hline Other & $\begin{array}{l}\text { Residential Cluster (requires easement around } \\
\text { perimeter to preserve existing trees and } \\
\text { vegetation) zo } \\
\text { A } 50 \text { foot perimeter no cut buffer required } \\
\text { for outer lots adjacent to a public street }\end{array}$ & $\begin{array}{ll} & \text { Adhered to } \\
50 \text {-foot perimeter buffer } \\
\text { strictly adhered to. } \\
\text { Street trees are important to } \\
\text { town }\end{array}$ \\
\hline
\end{tabular}




\section{TOWN OF SOUTH KINGSTOWN PROFILE}

\section{Summary}

South Kingstown's planning capacity is the highest in the study area. The Town is also one of the most suburbanized. The Town's large planning department and extensive technical expertise is, however, off-set by a more diverse range of political and development interests. In other words, broad consensus on planning issues is less likely to occur. There is consensus, however, among town planning officials on the need to preserve open spaces and protect critical natural resources, particularly the Town's surface and groundwater resources. Protecting the Town's village and coastal aesthetic is an important motivation guiding land conservation efforts.

The Town has adopted many of its comprehensive plan objectives, and is continually updating and strengthening its development regulations. The Town actively participates in collaborations with neighboring towns, university-based research organizations, and state and federal agencies. The town council is in the process of reviewing a proposed wastewater management plan and accompanying ordinance as well as an innovative flexible design zoning ordinance. The Town is currently in the process of purchasing development rights to a 160 acre farm, and is pursuing easements along rivers and ponds through a "community partnership project" with the Rhode Island Department of Environmental Management, The Nature Conservancy, the Champlin Foundation, and the South Kingstown Land Trust.

\section{Planning Department}

The South Kingstown Planning Department is comprised of three full-time planners and a full-time GIS technician. The Town's in-house professional and technical capacity is very high. How that capacity is actually implemented on a project by project basis is less certain. The Director of Planning, interviewed for this study, would provide very little information on 
implementation efforts. It was made clear during the interview that the town council, the zoning board of review and the planning board were not always in agreement about long-term planning issues. There is, however, a very strong conservation ethos in town. The only capacity limitation mentioned was the need for more public education and participation in the planning process.

\section{Comprehensive Plan Objectives}

South Kingstown has adopted many of its comprehensive plan objectives.

The Town directly links an important environmental regulation to its comprehensive plan. The Town requires an environmental impact statement (EIS), "if all or part of the property....includes land identified on Map 5.3 of the Comprehensive Community Plan of 1992 as being within a Critical and Environmentally Sensitive Area." The planning board only requires an EIS one out of thirty or so development proposals.

The plan should be updated to provide better guidance for future decisionmaking. Based on the interview for this study, it appears that the planning department does not find the current plan useful or authoritative for guiding regulatory change. In fact, the planner was dismissive of, or ignorant about, a number of the plans objectives. The planner's attitude may be an indication that the plan is outdated. Also, the Town may have suffered legal defeat, some years ago, trying to implement stricter buffer zones for wetlands and water bodies. This was an important policy object in the plan.

\section{Site Analysis}

South Kingstown is the only town in the study area with full in-house GIS capacity. The Town's parcel data is digitized and the GIS technician creates and updates GIS coverages on a day-to-day basis. The Town also requires, in its site design standards, that all major subdivisions (as well as minor subdivisions on a case-by-case basis) provide a detailed environmental site analysis. The planning department has a full-time environmental planner. The planning board rarely requires an EIS. It is possible that the board relies on its 
in-house capacity to conduct environmental assessments. The planner interviewed for this study did not discuss the planning department's site analysis procedures.

\section{Zoning and Subdivision Regulations}

\section{Zoning Ordinances}

- Farmland Zoning-The Town has a farm stand ordinance

- Residential Cluster Development-- Residential cluster developments are permitted uses in the R20, 30, 40, 80 and 200 districts. The ordinance requires that 40 percent of the gross area must be open space, not including stormwater drainage facilities; no more than 50 percent of the open space can be land unsuitable for development. The planning board can require cluster development for a particular subdivision.

- Large Lot Residential Zoning-R200 and R80.

- Environmental Protection Overlay Districts-The Town has three such districts: 1) Carrying Capacity Overlay District, 2) High Flood Danger Overlay District, and 3) Groundwater Protection Overlay District.

- Site Plan Review-The Town has a development plan review ordinance

- Performance Standards-(see development plan review ordinance)

\section{Subdivision and Land Development Regulations}

- Land Unsuitable for Development-Shall not be counted toward the minimum lot size requirements-- freshwater wetlands, except that area of perimeter wetland within 50 feet of the edge of any bog, marsh, swamp or pond; or any applicable 100 foot or 200 foot riverbank wetlands; coastal wetlands except any directly associated contiguous areas; areas within a High Flood Danger zone; land within any publicly or privately held easement on which above ground utilities, including but not limited to electrical transmission lines.

- Environmental Analysis-The planning board can require an EIS, though rarely does.

- Erosion and Sediment Contro/-Erosion and sediment control plans are required for all major subdivisions and land developments, and for any development occurring near environmentally sensitive areas.

- Site Design Standards-The Town's site design standards are fairly comprehensive. A mandatory site analysis requirement for all major subdivisions (and for minor subdivisions if required by the planning board), further ensures environmental considerations in site design. 


\section{South Kingstown Comprehensive Plan Matrix}

\begin{tabular}{|l|l|l|}
\hline Issue Area & $\begin{array}{l}\text { Comprehensive Planning } \\
\text { Objective }\end{array}$ & Implementation \\
\hline
\end{tabular}

\begin{tabular}{|c|c|c|}
\hline $\begin{array}{l}\text { Farmland } \\
\text { Preservation }\end{array}$ & & \\
\hline & $\begin{array}{l}\text { The town shall pursue } \\
\text { easements to protect open } \\
\text { land, including agricultural } \\
\text { land and areas along the } \\
\text { shoreline, that contribute to } \\
\text { the historic context of the } \\
\text { town }\end{array}$ & $\begin{array}{l}\text { The Town is pursuing easements through a } \\
\text { "community partnership" program with } \\
\text { TNC, DEM, the Champlin Foundation } \\
\text { and the Land Trust }\end{array}$ \\
\hline & $\begin{array}{l}\text { Subdivision regulations shall } \\
\text { be revised to include } \\
\text { specific provisions for } \\
\text { housing developments and } \\
\text { residential subdivisions } \\
\text { which create a village } \\
\text { identity; provide flexible } \\
\text { standards for...conservation } \\
\text { of natural resources, } \\
\text { agricultural land and open } \\
\text { space; and preservation of } \\
\text { scenic features and historic } \\
\text { resources } \\
\end{array}$ & $\begin{array}{l}\text { The Town is trying to adopt a new } \\
\text { "flexible design ordinance" that would } \\
\text { replace some existing zoning with } \\
\text { performance based standards }\end{array}$ \\
\hline & $\begin{array}{l}\text { - The town will revise its } \\
\text { zoning regulations as } \\
\text { required to incorporate } \\
\text { applicable standards for } \\
\text { rural land development (LU, } \\
\text { p.70)." }\end{array}$ & $>$ Same as above \\
\hline $\begin{array}{l}\text { Open Space } \\
\text { Zoning }\end{array}$ & & \\
\hline $\begin{array}{l}\text { Open Space } \\
\text { Preservation }\end{array}$ & & $\triangleright$ \\
\hline & - Pursue Easements & $\begin{array}{l}\text { The Town is pursuing easements through a } \\
\text { "community partnership" program with } \\
\text { TNC, DEM, the Champlin Foundation } \\
\text { and the Land Trust }\end{array}$ \\
\hline & $\begin{array}{l}\text { - Encourage the dedication of } \\
\text { open space }\end{array}$ & \\
\hline & $\begin{array}{l}\text { Pursue land acquisition and } \\
\text { protection strategies (along } \\
\text { rivers and other waterways). }\end{array}$ & $\begin{array}{l}\text { The Town Council has developed a point } \\
\text { system and priority list for land acquisition }\end{array}$ \\
\hline & $\begin{array}{l}\text { Identified greenways will be } \\
\text { protected from the adverse } \\
\text { effects of development } \\
\text { through zoning and land use } \\
\text { policies }\end{array}$ & $>$ \\
\hline
\end{tabular}




\begin{tabular}{|l|l|l|}
\hline Issue Area & $\begin{array}{l}\text { Comprehensive Planning } \\
\text { Objective }\end{array}$ & Implementation \\
\hline
\end{tabular}

\begin{tabular}{|c|c|c|}
\hline $\begin{array}{l}\text { Open Space } \\
\text { Preservation } \\
\text { (continued) }\end{array}$ & $\begin{array}{l}\text { Subdivision regulations shall } \\
\text { be revised to include } \\
\text { specific provisions for } \\
\text { housing developments and } \\
\text { residential subdivisions } \\
\text { which create a village } \\
\text { identity; provide flexible } \\
\text { standards for...conservation } \\
\text { of natural resources, } \\
\text { agricultural land and open } \\
\text { space; and preservation of } \\
\text { scenic features and historic } \\
\text { resources }\end{array}$ & $\begin{array}{l}\text { The Town is trying to adopt a new } \\
\text { "flexible design ordinance" that would } \\
\text { replace some existing zoning with } \\
\text { performance based standards }\end{array}$ \\
\hline \multicolumn{3}{|l|}{$\begin{array}{l}\text { Natural } \\
\text { Resource } \\
\text { Protection }\end{array}$} \\
\hline \multirow[t]{3}{*}{ Wetlands } & $\begin{array}{l}\text { "The town shall revise the } \\
\text { Zoning Ordinance } \\
\text { requirements for site plan } \\
\text { review to include such } \\
\text { specific recommendations } \\
\text { for protection of natural } \\
\text { resources such as ground } \\
\text { and surface water, wetlands, } \\
\text { soil, and trees }(\mathrm{N} / \mathrm{C}, \mathrm{p} .51) . "\end{array}$ & $>$ adopted \\
\hline & $\begin{array}{l}\text { "The town shall develop a } \\
\text { system to track the State } \\
\text { wetland permits to identify } \\
\text { areas of wetland disturbance } \\
\text { and to monitor compliance } \\
\text { with local and state approval } \\
\text { conditions (N/C, p.48)." }\end{array}$ & $\begin{array}{l}\text { The Town submits all permits to the } \\
\text { conservation commission for review }\end{array}$ \\
\hline & $\begin{array}{l}\text { "The town shall adopt a } \\
\text { wetland protection } \\
\text { ordinance to protect specific } \\
\text { areas identified as critical } \\
\text { wetland resource areas } \\
\text { (N/C, p.48)." }\end{array}$ & $>$ Not adopted \\
\hline
\end{tabular}




\section{South Kingstown Comprehensive Plan Matrix}

\begin{tabular}{|l|l|l|}
\hline Issue Area & $\begin{array}{l}\text { Comprehensive Planning } \\
\text { Objective }\end{array}$ & Implementation \\
\hline
\end{tabular}

\begin{tabular}{|c|c|c|}
\hline $\begin{array}{l}\text { Watercourse/ } \\
\text { Surface } \\
\text { waters }\end{array}$ & & \\
\hline & $\begin{array}{l}\text { "The town shall revise the } \\
\text { Zoning Ordinance } \\
\text { requirements for site plan } \\
\text { review to include such } \\
\text { specific recommendations } \\
\text { for protection of natural } \\
\text { resources such as ground } \\
\text { and surface water, wetlands, } \\
\text { soil, and trees (N/C, p.51)." }\end{array}$ & - Adopted \\
\hline & $\begin{array}{l}\text { "The town shall adopt a } \\
\text { river corridor overlay } \\
\text { protection district to } \\
\text { protect: a) the wildlife } \\
\text { habitat associated with the } \\
\text { rivers; b) the scenic, rural } \\
\text { quality associated with the } \\
\text { rivers; and c) the water } \\
\text { quality of the rivers (N/C, } \\
\text { p.48)." }\end{array}$ & - Not adopted \\
\hline & $\begin{array}{l}\text { "The town shall pursue } \\
\text { acquisition and protection } \\
\text { strategies for developing } \\
\text { greenways or natural } \\
\text { corridors along rivers and } \\
\text { other waterways in town } \\
\text { (N/C,p.52)." }\end{array}$ & $\begin{array}{l}\text { The Town is pursuing easements through a } \\
\text { "community partnership" progtam with } \\
\text { TNC, DEM, the Champlin Foundation } \\
\text { and the Land Trust } \\
\text { The Town Council has developed a point } \\
\text { system and priority list for land acquisition }\end{array}$ \\
\hline & $\begin{array}{l}\text { "A program of water } \\
\text { conservation will be } \\
\text { developed in conjunction } \\
\text { with a Wastewater } \\
\text { Management Program to be } \\
\text { initiated in the salt pond } \\
\text { region of town } \\
\text { (Services\&Facilities, p.45)." }\end{array}$ & \\
\hline
\end{tabular}




\begin{tabular}{|l|l|l|}
\hline Issue Area & $\begin{array}{l}\text { Comprehensive Planning } \\
\text { Objective }\end{array}$ & Implementation \\
\hline
\end{tabular}

\begin{tabular}{|c|c|c|c|}
\hline $\begin{array}{l}\text { Groundwater } \\
\text { /Recharge } \\
\text { Areas }\end{array}$ & & & \\
\hline & $\begin{array}{l}\text { "Land Inventory-The town } \\
\text { shall identify lands overlying } \\
\text { groundwater reservoirs and } \\
\text { recharge areas which may be } \\
\text { available for direct } \\
\text { purchases or purchase of } \\
\text { development rights and } \\
\text { develop a priority list } \\
\text { (Natural/Cultural, p. 46)." }\end{array}$ & $>$ & $\begin{array}{l}\text { The Town is pursuing easements through a } \\
\text { "community partnership" program with } \\
\text { TNC, DEM, the Champlin Foundation } \\
\text { and the Land Trust } \\
\text { The Town Council has developed a point } \\
\text { system and priority list for land acquisition }\end{array}$ \\
\hline & $\begin{array}{l}\text { "A program of water } \\
\text { conservation will be } \\
\text { developed in conjunction } \\
\text { with a Wastewater } \\
\text { Management Program to be } \\
\text { initiated in the salt pond } \\
\text { region of town } \\
\text { (Services\&Facilities, p.45)." }\end{array}$ & $D$ & $\begin{array}{l}\text { Town is working on a Wastewater } \\
\text { Management Ordinance }\end{array}$ \\
\hline & $\begin{array}{l}\text { "The town shall revise the } \\
\text { Zoning Ordinance } \\
\text { requirements for site plan } \\
\text { review to include such } \\
\text { specific recommendations } \\
\text { for protection of natural } \\
\text { resources as ground and } \\
\text { surface water, wetlands, soil, } \\
\text { and trees }(\mathrm{N} / \mathrm{C}, \mathrm{p} .51) . "\end{array}$ & $>$ & Adopted \\
\hline \multicolumn{4}{|l|}{ Floodplains } \\
\hline \multicolumn{4}{|l|}{$\begin{array}{l}\text { Coastal } \\
\text { Features }\end{array}$} \\
\hline & $\begin{array}{l}\text { "A program of water } \\
\text { conservation will be } \\
\text { developed in conjunction } \\
\text { with a Wastewater } \\
\text { Management Program to be } \\
\text { initiated in the salt pond } \\
\text { region of town } \\
\text { (Services\&Facilities, p.45)." }\end{array}$ & & $\begin{array}{l}\text { A Wastewater Management Plan and } \\
\text { ordinance are presently under review by the } \\
\text { town council }\end{array}$ \\
\hline
\end{tabular}




\begin{tabular}{|l|l|l|}
\hline Issue Area & $\begin{array}{l}\text { Comprehensive Planning } \\
\text { Objective }\end{array}$ & Implementation \\
\hline
\end{tabular}

\begin{tabular}{|c|c|c|}
\hline Topography & $\begin{array}{l}\text { "The town shall revise the } \\
\text { Zoning Ordinance } \\
\text { requirements for site plan } \\
\text { review to include such } \\
\text { specific recommendations } \\
\text { for protection of natural } \\
\text { resources such as ground } \\
\text { and surface water, wetlands, } \\
\text { soil, and trees (N/C, p.51)." }\end{array}$ & $>$ Adopted \\
\hline \multicolumn{3}{|l|}{$\begin{array}{l}\text { Rare species/ } \\
\text { Critical } \\
\text { habitat }\end{array}$} \\
\hline \multirow[t]{3}{*}{$\begin{array}{l}\text { Trees/ } \\
\text { Woodlands }\end{array}$} & $\begin{array}{l}\text { "The town shall revise the } \\
\text { Zoning Ordinance } \\
\text { requirements for site plan } \\
\text { review to include such } \\
\text { specific recommendations } \\
\text { for protection of natural } \\
\text { resources such as ground } \\
\text { and surface water, wetlands, } \\
\text { soil, and trees (N/C, p.51)." }\end{array}$ & $>$ Adopted \\
\hline & $\begin{array}{l}\text { - The town shall implement a } \\
\text { tree ordinance which } \\
\text { includes a Tree } \\
\text { Conservation Plan to ensure } \\
\text { protection of the natural } \\
\text { resource... The town shall } \\
\text { inventory the indigenous } \\
\text { habitat types and identify } \\
\text { areas which need protection } \\
\text { (N/C, p.51). }\end{array}$ & $\begin{array}{l}\text { Tree Ordinance adopted for public rights- } \\
\text { of-way }\end{array}$ \\
\hline & $\begin{array}{l}\text { - Adopt a "Landscaping } \\
\text { Manual" }\end{array}$ & Not adopted \\
\hline
\end{tabular}


South Kingstown Comprehensive Plan Matrix

\begin{tabular}{|l|l|l|}
\hline Issue Area & $\begin{array}{l}\text { Comprehensive Planning } \\
\text { Objective }\end{array}$ & Implementation \\
\hline
\end{tabular}

\begin{tabular}{|l|l|l|}
\hline $\begin{array}{l}\text { Cultural/ } \\
\text { Ristoric } \\
\text { Resources }\end{array}$ & & \\
\hline $\begin{array}{l}\text { Village/Rural } \\
\text { Character }\end{array}$ & $\bullet \begin{array}{l}\text { Create provisions in } \\
\text { subdivision regulations }\end{array}$ & \\
\hline & $\begin{array}{l}\text { Revise zoning to } \\
\text { incorporate applicable } \\
\text { standards for rural land } \\
\text { development }\end{array}$ & \\
\hline & $\begin{array}{l}\text { Amend zoning regulations } \\
\text { to control commercial } \\
\text { development along roads } \\
\text { and highways }\end{array}$ & \\
\hline & $\begin{array}{l}\text { Allow for inclusion of } \\
\text { mixed-use of existing } \\
\text { industrial and commercial } \\
\text { buildings in historic districts }\end{array}$ & \\
\hline & $\begin{array}{l}\text { Prepare a landscaping } \\
\text { manual }\end{array}$ & \\
\hline
\end{tabular}


South Kingstown Municipal Protections

\begin{tabular}{|l|l|l|}
\hline $\begin{array}{l}\text { Natural } \\
\text { Resource } \\
\text { Protection }\end{array}$ & $\begin{array}{l}\text { Municipal Protection } \\
\text { Measure }\end{array}$ & Implementation \\
\hline
\end{tabular}

\begin{tabular}{|c|c|c|}
\hline $\begin{array}{l}\text { Land } \\
\text { Conservation }\end{array}$ & & \\
\hline $\begin{array}{l}\text { Farmland } \\
\text { Preservation }\end{array}$ & & \\
\hline Zoning Regulations & $\begin{array}{l}\text { R200 Zone (may discourage } \\
\text { conversion of open space and } \\
\text { farmlands) }\end{array}$ & $\begin{array}{l}\text { Planner thinks the zone does } \\
\text { discourage conversion of large } \\
\text { parcels. } \\
\text { The Town is trying to buy the } \\
\text { development rights to a } 160 \text { acre } \\
\text { farm in town using bonded open } \\
\text { space funds from town and } \\
\text { DEM grant monies. }\end{array}$ \\
\hline Site Design & $\begin{array}{ll}\text { - } & \text { Site Design Standards (may require } \\
\text { preservation efforts) } \\
\text { - Lot Development Standards } \\
\text { (Minor Subdivision Criteria for } \\
\text { Review may include "Preservation } \\
\text { of Agricultural Land" through } \\
\text { clustering requirements }\end{array}$ & \\
\hline Other & - Farm stand Ordinance & \\
\hline $\begin{array}{l}\text { Open Space } \\
\text { Zoning }\end{array}$ & & \\
\hline & $\begin{array}{l}\text { - Residential uses prohibited except } \\
\text { for single and two households farm } \\
\text { residences as an accessory use } \\
\text { Permitted uses "by right" include: } \\
\text { crop and livestock farms (pig farms } \\
\text { prohibited), fish hatcheries, and } \\
\text { boarding animals, outdoor } \\
\text { recreation facilities such as golf } \\
\text { courses and tennis courts and } \\
\text { wildlife refuges } \\
\text { - Museums, libraries, community } \\
\text { centers, cemeteries allowed by } \\
\text { "special use permit" }\end{array}$ & \\
\hline
\end{tabular}


South Kingstown Municipal Protections

\begin{tabular}{|l|l|l|}
\hline $\begin{array}{l}\text { Natural } \\
\text { Resource } \\
\text { Protection }\end{array}$ & $\begin{array}{l}\text { Municipal Protection } \\
\text { Measure }\end{array}$ & Implementation \\
\hline
\end{tabular}

\begin{tabular}{|c|c|c|}
\hline $\begin{array}{l}\text { Open Space } \\
\text { Preservation }\end{array}$ & & \\
\hline $\begin{array}{l}\text { Cluster } \\
\text { Development, } \\
\text { Residential } \\
\text { Compounds, Large } \\
\text { Lot Zoning }\end{array}$ & $\begin{array}{l}\text { Residential cluster developments } \\
\text { and compounds are permitted uses } \\
\text { in the R20,30,40, } 80 \text { and } 200 \\
\text { districts (40\% of the gross area } \\
\text { must be open space, not including } \\
\text { stormwater drainage facilities; no } \\
\text { more than } 50 \% \text { of the open space } \\
\text { can be land unsuitable for } \\
\text { development) } \\
\text { Planning Board can require cluster } \\
\text { development for a particular } \\
\text { subdivision }\end{array}$ & \\
\hline $\begin{array}{l}\text { Land Unsuitable for } \\
\text { Development }\end{array}$ & $\begin{array}{l}\text { Land Unsuitable for Development } \\
\text { (shall not be counted toward the } \\
\text { minimum lot size requirements-- } \\
\text { freshwater wetlands, except that area } \\
\text { of perimeter wetland within } 50 \text { feet of } \\
\text { the edge of any bog, marsh, swamp or } \\
\text { pond; or any applicable } 100 \text { foot or } \\
200 \text { foot riverbank wetlands; coastal } \\
\text { wetlands except any directly associated } \\
\text { contiguous areas; areas within a High } \\
\text { Flood Danger zone; land within any } \\
\text { publicly or privately held easement on } \\
\text { which above ground utilieies, including } \\
\text { but not limited to electrical } \\
\text { transmission lines, are constructed) }\end{array}$ & Adhered to \\
\hline $\begin{array}{l}\text { Dedication of Land } \\
\text { for Public Purposes }\end{array}$ & $\begin{array}{l}\text { Dedication of Land for Public } \\
\text { Purposes (land or payment in lieu } \\
\text { required for all subdivisions; land } \\
\text { dedication is } 10.50 \text { acres per } 1,000 \text { ) }\end{array}$ & As part of the impact fee \\
\hline Site Design & $\begin{array}{l}\text { Subdivision and Site Design (see } \\
\text { preferred areas for preservarion) }\end{array}$ & Adhered to \\
\hline
\end{tabular}


South Kingstown Municipal Protections

\begin{tabular}{|l|l|l|}
\hline $\begin{array}{l}\text { Natural } \\
\text { Resource } \\
\text { Protection }\end{array}$ & $\begin{array}{l}\text { Municipal Protection } \\
\text { Measure }\end{array}$ & Implementation \\
\hline
\end{tabular}

\begin{tabular}{|c|c|c|}
\hline $\begin{array}{l}\text { Natural } \\
\text { Resource } \\
\text { Protection }\end{array}$ & & \\
\hline \multicolumn{3}{|l|}{ Wetlands } \\
\hline $\begin{array}{l}\text { Erosion and } \\
\text { Sediment Control } \\
\text { Plan }\end{array}$ & $\begin{array}{l}\text { Erosion and Sediment Control } \\
\text { Performance Principles (Plan is } \\
\text { required for all major subdivisions } \\
\text { and land developments and for all } \\
\text { development if construction } \\
\text { activities are within } 100 \text { feet of a } \\
\text { wetland or coastal feature) }\end{array}$ & $\begin{array}{l}\text { Adhered to } \\
\text { The planning department, the } \\
\text { public works director and the } \\
\text { town engineers monitor sites } \\
>95 \% \text { compliance }\end{array}$ \\
\hline Protection District & $\begin{array}{l}\text { - } \quad \text { Carrying Capacity Overlay District } \\
\text { (SAMP Areas) zo }\end{array}$ & $>$ Adhered to \\
\hline Setbacks & $\begin{array}{l}\text { - Special Use Permits, Location of } \\
\text { ISDS (no facility designed to leach } \\
\text { liquid wastes into the soil shall be } \\
\text { located within } 150 \text { feet of a } \\
\text { freshwater wetland...) zo }\end{array}$ & $>$ Strictly adhered to \\
\hline $\begin{array}{l}\text { Land Unsuitable for } \\
\text { Development }\end{array}$ & - Land Unsuitable for Development & Strictly adhered to \\
\hline $\begin{array}{l}\text { Environmental } \\
\text { Analysis/Impact } \\
\text { Analysis }\end{array}$ & $\begin{array}{l}\text { EIS (may be required if land is } \\
\text { located on Map } 5.3 \text { of the } \\
\text { Comprehensive Plan as being } \\
\text { within a critical or environmentally } \\
\text { sensitive area or by authority of the } \\
\text { Planning Board) }\end{array}$ & $\begin{array}{l}\text { Requested for every } 30 \text { to } 40 \\
\text { proposals }\end{array}$ \\
\hline Site Design & $\begin{array}{l}\text { - Site Design Standards (may require } \\
\text { preservation efforts) } \\
\text { - Site Analysis required for all major } \\
\text { subdivisions }\end{array}$ & $D$ Strictly adhered to \\
\hline Site Plan Review & $\begin{array}{l}\text { - Development Plan Review, } \\
\text { Performance Standards }\end{array}$ & \\
\hline $\begin{array}{l}\text { Performance } \\
\text { Standards }\end{array}$ & & \\
\hline
\end{tabular}


South Kingstown Municipal Protections

\begin{tabular}{|l|l|l|}
\hline $\begin{array}{l}\text { Natural } \\
\text { Resource } \\
\text { Protection }\end{array}$ & $\begin{array}{l}\text { Municipal Protection } \\
\text { Measure }\end{array}$ & Implementation \\
\hline
\end{tabular}

\begin{tabular}{|c|c|c|}
\hline $\begin{array}{l}\text { Watercourse/ } \\
\text { Surface Waters }\end{array}$ & & \\
\hline $\begin{array}{l}\text { Erosion and } \\
\text { Sediment Control } \\
\text { Plan }\end{array}$ & $\begin{array}{l}\text { Erosion and Sediment Control } \\
\text { Performance Principles (Required } \\
\text { for all major subdivisions and land } \\
\text { developments and for all } \\
\text { development if construction } \\
\text { activities are within } 100 \text { feet of a } \\
\text { wetland or coastal feature) }\end{array}$ & $\begin{array}{l}\text { Adhered to } \\
\text { The planning department and } \\
\text { the town engineers monitor sites } \\
95 \% \text { compliance }\end{array}$ \\
\hline Protection District & 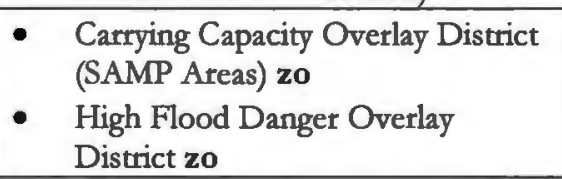 & Adhered to \\
\hline $\begin{array}{l}\text { Environmental } \\
\text { Analysis/Impact } \\
\text { Analysis }\end{array}$ & $\begin{array}{l}\text { EIS (may be required if land is } \\
\text { located on Map } 5.3 \text { of the } \\
\text { Comprehensive Plan as being } \\
\text { within a critical or environmentally } \\
\text { sensitive area or by authority of the } \\
\text { Planning Board) }\end{array}$ & $\begin{array}{l}\text { Requested for every } 30 \text { to } 40 \\
\text { proposals }\end{array}$ \\
\hline Setbacks & $\begin{array}{l}\text { Hazardous Waste Facility setback } \\
\text { requirements zo } \\
\text { - Special Use Permits, Location of } \\
\text { ISDS (no facility designed to leach } \\
\text { liquid wastes into the soil shall be } \\
\text { located within } 150 \text { feet of a } \\
\text { river...) zo }\end{array}$ & $\begin{array}{l}>\text { Adhered to } \\
\text { Adhered to }\end{array}$ \\
\hline Site Design & - Site Analysis & \\
\hline \multicolumn{3}{|l|}{ Site Plan Review } \\
\hline $\begin{array}{l}\text { Performance } \\
\text { Standards }\end{array}$ & $\begin{array}{l}\text { - Industrial Performance Standards } \\
\text { zo }\end{array}$ & \\
\hline
\end{tabular}




\section{South Kingstown Municipal Protections}

\begin{tabular}{|l|l|l|}
\hline $\begin{array}{l}\text { Natural } \\
\text { Resource } \\
\text { Protection }\end{array}$ & $\begin{array}{l}\text { Municipal Protection } \\
\text { Measure }\end{array}$ & Implementation \\
\hline
\end{tabular}

\begin{tabular}{|c|c|c|}
\hline $\begin{array}{l}\text { Groundwater/ } \\
\text { Recharge Areas }\end{array}$ & & \\
\hline Protection District & $\begin{array}{l}\text { - Groundwater Protection Overlay } \\
\text { District zo }\end{array}$ & Strictly adhered to \\
\hline $\begin{array}{l}\text { Environmental } \\
\text { Analysis/Impact } \\
\text { Statement }\end{array}$ & $\begin{array}{l}\text { EIS (may be required if land is } \\
\text { located on Map } 5.3 \text { of the } \\
\text { Comprehensive Plan as being } \\
\text { within a critical or environmentally } \\
\text { sensitive area or by authority of the } \\
\text { Planning Board) }\end{array}$ & $\begin{array}{l}\text { Requested every } 30 \text { to } 40 \\
\text { development proposals }\end{array}$ \\
\hline Setbacks & & $>$ \\
\hline Site Design & $\begin{array}{l}\text { - Site Design Standards (siting must } \\
\text { avoid adverse impacts to } \\
\text { groundwater and aquifer recharge) } \\
\text { - Site Analysis }\end{array}$ & $>$ Strictly adhered to \\
\hline Site Plan Review & $\begin{array}{l}\text { - Development Plan Review, } \\
\text { Performance Principles }\end{array}$ & $>$ Strictly adhered to \\
\hline Other & $\begin{array}{l}\text { - Special Requirements (Residential } \\
\text { Cluster in R200 may be restricted } \\
\text { based on environmental } \\
\text { considerations) }\end{array}$ & \\
\hline \multicolumn{3}{|l|}{ Floodplains } \\
\hline Protection District & $\begin{array}{ll}\text { - } & \text { High Flood Danger Overlay } \\
\text { District } \\
\text { - } \quad \text { Carrying Capacity Overlay zo }\end{array}$ & \\
\hline $\begin{array}{l}\text { Land Unsuitable for } \\
\text { Development }\end{array}$ & - Land Unsuitable for Development & \\
\hline $\begin{array}{l}\text { Environmental } \\
\text { Analysis/Impact } \\
\text { Statement }\end{array}$ & $\begin{array}{l}\text { EIS (may be required if land is } \\
\text { located on Map } 5.3 \text { of the } \\
\text { Comprehensive Plan as being } \\
\text { within a critical or environmentally } \\
\text { sensitive area or by authority of the } \\
\text { Planning Board) }\end{array}$ & \\
\hline Setbacks & $\begin{array}{l}\text { ISDS Siting Restrictions/Setbacks } \\
\text { (no facility designed to leach liquid } \\
\text { wastes into the soil shall be located } \\
\text { within } 150 \text { feet of a flood plain...) } \\
\text { zo }\end{array}$ & \\
\hline Site Design & $\begin{array}{l}\text { - Site Design standards (may require } \\
\text { preservation efforts) } \\
\text { - Site Analysis } \\
\end{array}$ & \\
\hline \multicolumn{3}{|l|}{ Site Plan Review } \\
\hline Other & - Hazard Mitigation Plan & \\
\hline
\end{tabular}


South Kingstown Municipal Protections

\begin{tabular}{|l|l|l|}
\hline $\begin{array}{l}\text { Natural } \\
\text { Resource } \\
\text { Protection }\end{array}$ & $\begin{array}{l}\text { Municipal Protection } \\
\text { Measure }\end{array}$ & Implementation \\
\hline
\end{tabular}

\begin{tabular}{|c|c|c|}
\hline \multicolumn{3}{|l|}{ Topography } \\
\hline $\begin{array}{l}\text { Erosion and } \\
\text { Sediment Control } \\
\text { Plan }\end{array}$ & $\begin{array}{l}\text { Erosion and Sediment Control } \\
\text { Pcrformancc Principles (Plan is } \\
\text { required for all subdivisions if } \\
\text { slopes at the site exceed 10\%) }\end{array}$ & \\
\hline \multicolumn{3}{|l|}{$\begin{array}{l}\text { Land Unsuitable for } \\
\text { Development }\end{array}$} \\
\hline Site Design & $\begin{array}{l}\text { Site Design (stecp slopes in excess } \\
\text { of } 20 \% \text { as measured over a } 10 \text { foot } \\
\text { interval unless appropriate } \\
\text { engincering measures concerning } \\
\text { slope stability, crosion, and } \\
\text { resident safety are taken shall be } \\
\text { preserved as open space where } \\
\text { feasible) }\end{array}$ & $\begin{array}{l}\text { Does not consider steep slopes } \\
\text { to be a problem }\end{array}$ \\
\hline \multicolumn{3}{|l|}{ Site Plan Review } \\
\hline \multicolumn{3}{|l|}{$\begin{array}{l}\text { Rare Species } \\
\text { /Critical } \\
\text { Habitat }\end{array}$} \\
\hline Protection District & $\begin{array}{l}\text { - R200 Zone (intended to protect } \\
\text { environmentally sensirive areas: } \\
\text { aquifers, recharge areas, and coastal } \\
\text { ponds) }\end{array}$ & \\
\hline $\begin{array}{l}\text { Environmental } \\
\text { Analysis/Impact } \\
\text { Statement }\end{array}$ & $\begin{array}{l}\text { EIS (may be required if land is located } \\
\text { on Map 5.3 of the Comprehensivc Plan } \\
\text { as being w within a crivical or } \\
\text { environmentally sensitive area or by } \\
\text { authority of the Planning Board) }\end{array}$ & $\begin{array}{l}\text { Requested every } 30 \text { to } 40 \\
\text { development proposals }\end{array}$ \\
\hline Setbacks & $\begin{array}{l}\text { - Hazardous Waste Facility sctback } \\
\text { requirements zo }\end{array}$ & \\
\hline Site Design & $\begin{array}{l}\text { - Sitc Design (habitat of endangered } \\
\text { species shall be preserved as open } \\
\text { space where feasible; site analysis for } \\
\text { all major developments and } \\
\text { subdivisions) } \\
\text { - Sitc Analysis } \\
\end{array}$ & $\begin{array}{l}\text { Strictly adhered to } \\
\text { The Town enforces DEM's } \\
\text { Natural Heritage Program } \\
\text { standards }\end{array}$ \\
\hline Site Plan Review & & \\
\hline
\end{tabular}


South Kingstown Municipal Protections

\begin{tabular}{|l|l|l|}
\hline $\begin{array}{l}\text { Natural } \\
\text { Resource } \\
\text { Protection }\end{array}$ & $\begin{array}{l}\text { Municipal Protection } \\
\text { Measure }\end{array}$ & Implementation \\
\hline
\end{tabular}

\begin{tabular}{|l|l|l|}
\hline $\begin{array}{l}\text { Trees/ } \\
\text { Woodlands }\end{array}$ & \\
\hline $\begin{array}{l}\text { Erosion and } \\
\text { Sediment Control } \\
\text { Plan }\end{array}$ & $\begin{array}{l}\text { Erosion and Sediment Control } \\
\text { Performance Principles (may } \\
\text { require protection of existing trees } \\
\text { and vegetation) }\end{array}$ & Strictly adhered to \\
\hline Site Design & $\begin{array}{l}\text { Site Design Standards (may require } \\
\text { preservation efforts) } \\
\text { Lot Development Standards (may } \\
\text { require preservation of existing } \\
\text { unique features) }\end{array}$ & Adhered to \\
\hline Site Analysis
\end{tabular}


South Kingstown Municipal Protections

\begin{tabular}{|l|l|l|}
\hline $\begin{array}{l}\text { Natural } \\
\text { Resource } \\
\text { Protection }\end{array}$ & $\begin{array}{l}\text { Municipal Protection } \\
\text { Measure }\end{array}$ & Implementation \\
\hline
\end{tabular}

\begin{tabular}{|c|c|c|}
\hline $\begin{array}{l}\text { Coastal } \\
\text { Features } \\
\text { (continued) }\end{array}$ & & \\
\hline Site Design & $\begin{array}{ll}\text { - } & \text { Site Design Standards (may require } \\
\text { preservation as open space) } \\
\text { - } \\
\end{array}$ & \\
\hline \multicolumn{3}{|l|}{ Site Plan Review } \\
\hline Other & $\begin{array}{l}\text { - Special Requirements (Residential } \\
\text { Cluster in R200 may be restricted } \\
\text { based on environmental } \\
\text { considerations) zo } \\
\text { R200 Zone (intended to protect } \\
\text { environmentally sensitive areas: } \\
\text { aquifers, recharge areas, and coastal } \\
\text { ponds) zo }\end{array}$ & \\
\hline \multicolumn{3}{|l|}{$\begin{array}{l}\text { Village/Rural } \\
\text { Character }\end{array}$} \\
\hline Overlay Districts & $\begin{array}{l}\text { Architectural Standards of Review } \\
\text { Required (Historic Overlay } \\
\text { District; Route } 1 \text { Special } \\
\text { Management District) zo } \\
\text { - Historic Overlay District (includes } \\
\text { an area within the Village of } \\
\text { Kingston) zo } \\
\end{array}$ & \\
\hline $\begin{array}{l}\text { Cluster Development, } \\
\text { Residential Compounds, } \\
\text { Lange Lot Zoning }\end{array}$ & - R200 Zone & \\
\hline Site Design & $\begin{array}{l}\text { Site Design Standards (special } \\
\text { provisions for flexible lot size, lot lines, } \\
\text { frontage, and setbacks; calls for the } \\
\text { placement of dwelling units to take } \\
\text { into consideration...scenic values) } \\
\text { Lot Development Standards (may } \\
\text { require the preservation of historic } \\
\text { features such as trees or stone walls) }\end{array}$ & \\
\hline Site Plan Reviens & $\begin{array}{l}\text { Site Plan Review ( required for } \\
\text { properties with direct lot frontage } \\
\text { or vehicular access on Ministerial } \\
\text { Road Scenic Highway) }\end{array}$ & \\
\hline Historic Preservation & $\begin{array}{l}\text { Maintenance Standards and } \\
\text { procedures for identifying } \\
\text { endangered buildings (Building } \\
\text { Code) }\end{array}$ & \\
\hline \multicolumn{3}{|l|}{ Landscaping Standards } \\
\hline Street Design & $\begin{array}{l}\text { - Shared Common Drives } \\
\text { (encouraged for minor } 2 \text { lot } \\
\text { subdivisions) }\end{array}$ & \\
\hline
\end{tabular}




\section{Summary}

West Greenwich is in the process of significantly changing its development regulations. The planner interviewed for this study is very new to the Town. He has not been involved in the Town's development process. Consequently, this profile is abbreviated in order to minimize the inclusion of misinformed or biased information.

According to the town planner, there is broad consensus among town officials on the need to manage (limit) suburban growth, and significantly strengthen the Town's development regulations. The subdivision and land development regulations have recently undergone significant revisions. Notably, West Greenwich shares its town solicitor with South Kingstown. Many of the new revisions in the subdivision and land development regulations are modeled on South Kingstown's regulations. The Town is close to adopting an "interior building envelope" ordinance that will significantly reduce site design requirements for second homes on existing residential sites.

\section{Planning Department}

The Town employs one half-time planner (with no background in environmental management). The Town has not received a subdivision proposal in over six months. The Town has no in-house GIS capacity, nor does the town planner desire it. Most of the planning board members have a background in construction and engineering, and are diligent in their requirements for high quality development.

Planning capacity limitations are primarily technical in nature, but also include limited environmental planning expertise. The Town planner was unaware of the groundwater aquifer that lies beneath the Town's I-95 corridor. 


\section{Comprehensive Plan Objectives}

The Town's comprehensive plan objectives for natural resource protection

and land conservation are limited in comparison to other towns in the study. However, it appears that a good percentage of the objectives have been adopted or implemented in some alternative manner. The comprehensive plan should be updated to provide better standing for new regulatory changes.

\section{Site Analysis}

The interview with the town planner did not provide information of this topic. However, the subdivision and land development regulations have been revised to include a mandatory site analysis for all major subdivision (and for minor subdivisions on a case-by-case basis). The planning board has the authority to request an environmental impact statement for any development. The Town keeps an engineer on retainer for this purpose. According to the town planner, the planning board is very diligent about deducting "land unsuitable for development" from the building acreage of the parcel.

\section{Zoning and Subdivision Regulations}

\section{Zoning Ordinances}

- Farmland Zoning-none

- Residential Cluster Development-none

- Large Lot Residential Zoning-Rural, Farming, Residential (RFR 2)

- Overlay Districts-none

- Site Plan Review-The Town has very detailed environmental standards in its site plan review ordinance.

- Performance Standards-The Town has a unique 200 feet septic system setback requirement from water bodies.

\section{Subdivision and Land Development Regulations}

- Land Unsuitable for Development-Shall not be counted toward the minimum lot size requirements; it may be included as part of any lot in any subdivision or land development project; provided that land unsuitable for development shall not exceed $30 \%$ of the minimum lot size required in the zoning ordinance--freshwater wetlands, except that area of perimeter wetland within 50 feet of the edge of any bog, marsh, swamp or pond; or any applicable 100 foot or 200 foot riverbank wetlands; areas within a 100 
year flood zone; land within any publicly or privately held easement on which above ground utilities, including but not limited to electrical transmission lines; areas which exceed $15 \%$ slope.

- Environmental Analysis - the planning board has the authority to require an EIS for any development. An engineer is kept on retainer for this purpose.

- Erosion and Sediment Control-The Town requires an erosion and sediment control plan and the use of "best management practices" for all non-contiguous developments.

- Site Design Standards-The Town has a comprehensive list of environmental considerations in its site design standards. The Town has also adopted a mandatory site analysis for all major subdivisions (and minor subdivisions on a case-by-case basis). 
West Greenwich Comprehensive Plan Matrix

\begin{tabular}{|l|l|l|}
\hline Issue Area & $\begin{array}{l}\text { Comprehensive } \\
\text { Planning Objective }\end{array}$ & Implementation \\
\hline
\end{tabular}

\begin{tabular}{|c|c|c|}
\hline $\begin{array}{l}\text { Farmland } \\
\text { Preservation }\end{array}$ & & \\
\hline \multicolumn{3}{|l|}{$\begin{array}{l}\text { Open Space } \\
\text { Zoning }\end{array}$} \\
\hline \multicolumn{3}{|l|}{$\begin{array}{l}\text { Open Space } \\
\text { Preservation }\end{array}$} \\
\hline & $\begin{array}{l}\text { Adopt an Interior } \\
\text { Building Lot (IBL) } \\
\text { ordinance that promotes } \\
\text { limited development of } \\
\text { large tracts of land } \\
\text { thereby ensuring } \\
\text { preservation of open } \\
\text { space in perpetuity }\end{array}$ & The town council is in the process of adopting \\
\hline & $\begin{array}{l}\text { Institute Greenbelt } \\
\text { Overlay District in RFR-2 } \\
\text { district to protect open } \\
\text { space character by } \\
\text { guiding development to } \\
\text { areas on the property } \\
\text { which are appropriate }\end{array}$ & $\begin{array}{l}\text { Not as overlay district } \\
1.4 \text { acres of every } 2 \text { acre parcel must be land } \\
\text { suitable for development }\end{array}$ \\
\hline & $\begin{array}{l}\text { The Conservation } \\
\text { Commission and } \\
\text { Planning Board shall } \\
\text { promote Greenway } \\
\text { Corridor Connections } \\
\text { through cooperative } \\
\text { review of subdivision } \\
\text { plans and by identifying } \\
\text { select parcels worthy of } \\
\text { potential acquisition }\end{array}$ & $\begin{array}{l}\text { The conservation commission has been } \\
\text { informally granted strong oversight of } \\
\text { subdivision proposals }\end{array}$ \\
\hline & $\begin{array}{l}\text { The Conservation } \\
\text { Commission and } \\
\text { Planning Board shall } \\
\text { work closely with } \\
\text { developers to include a } \\
\text { Greenway component in } \\
\text { the Master Plan stage }\end{array}$ & Implemented \\
\hline
\end{tabular}


West Greenwich Comprehensive Plan Matrix

\begin{tabular}{|l|l|l|}
\hline Issue Area & $\begin{array}{l}\text { Comprehensive } \\
\text { Planning Objective }\end{array}$ & Implementation \\
\hline
\end{tabular}

\begin{tabular}{|c|c|c|}
\hline $\begin{array}{l}\text { Natural } \\
\text { Resource } \\
\text { Protection } \\
\end{array}$ & & \\
\hline & $\begin{array}{l}\text { Institute performance } \\
\text { standards in the Town's } \\
\text { zoning and subdivision } \\
\text { regulations that account } \\
\text { for environmental } \\
\text { constraints }\end{array}$ & $\begin{array}{l}\text { Not performance standards, but strong siting } \\
\text { considerations }\end{array}$ \\
\hline & $\begin{array}{l}\text { Adopt changes to } \\
\text { zoning/subdivision } \\
\text { regulations to require all } \\
\text { development applications } \\
\text { to identify the on-site } \\
\text { presence of natural } \\
\text { resources and constraints } \\
\text { to development } \\
\end{array}$ & $\begin{array}{l}\text { Site design standards include mandatory site } \\
\text { analysis for all major subdivisions or by } \\
\text { request of the planning board }\end{array}$ \\
\hline Wetlands & & \\
\hline $\begin{array}{l}\text { Watercourses/ } \\
\text { Surface water }\end{array}$ & & \\
\hline & $\begin{array}{l}\text { Require } 100 \text {-foot wide } \\
\text { conservation easements } \\
\text { for land in new } \\
\text { subdivisions bordering } \\
\text { water bodies }\end{array}$ & $\begin{array}{l}\text { The Town has a } 200 \text { foot septic setback for all } \\
\text { water bodies }\end{array}$ \\
\hline $\begin{array}{l}\text { Groundwater/ } \\
\text { Recharge } \\
\text { Areas }\end{array}$ & & \\
\hline Floodplains & & \\
\hline $\begin{array}{l}\text { Coastal } \\
\text { Features }\end{array}$ & & \\
\hline Topography & & \\
\hline & $\begin{array}{l}\text { Prohibit development in } \\
\text { those environmentally } \\
\text { sensitive areas where } \\
\text { slopes greater than or } \\
\text { equal to } 15 \% \text { are present } \\
\end{array}$ & $\begin{array}{l}\text { Slopes that exceed } 15 \% \text { are identified as } \\
\text { unsuitable for development }\end{array}$ \\
\hline $\begin{array}{l}\text { Rare Species/ } \\
\text { Critical } \\
\text { Habitat }\end{array}$ & & \\
\hline & $\begin{array}{l}\text { Ensure preservation of } \\
\text { wildlife habitat and rare } \\
\text { species of flora and fauna, } \\
\text { as identified in the } \\
\text { Natural Resource } \\
\text { inventory, through } \\
\text { coordinated review of } \\
\text { development plans } \\
\end{array}$ & May not have been implemented \\
\hline
\end{tabular}




\section{West Greenwich Comprehensive Plan Matrix}

\begin{tabular}{|l|l|l|}
\hline Issue Area & $\begin{array}{l}\text { Comprehensive } \\
\text { Planning Objective }\end{array}$ & Implementation \\
\hline
\end{tabular}

\begin{tabular}{|c|c|c|}
\hline $\begin{array}{l}\text { Trees/ } \\
\text { Woodlands }\end{array}$ & & \\
\hline $\begin{array}{l}\text { Cultural/ } \\
\text { Historic } \\
\text { Resources }\end{array}$ & & \\
\hline $\begin{array}{l}\text { Village/Rural } \\
\text { Character }\end{array}$ & & \\
\hline & $\begin{array}{l}\text { Establish a local zoning } \\
\text { map based on existing and } \\
\text { proposed land use } \\
\text { patterns, available } \\
\text { infrastructure, and those } \\
\text { environmental constraints } \\
\text { to development as } \\
\text { determined by the } \\
\text { COMPOSITE constraint } \\
\text { map }\end{array}$ & \\
\hline & $\begin{array}{l}\text { Identify and protect } \\
\text { natural/cultural resources } \\
\text { through development plan } \\
\text { review, design guidelines, } \\
\text { and flexible development } \\
\text { siting }\end{array}$ & \\
\hline & $\begin{array}{l}\text { Institute in the Zoning } \\
\text { Code variable lot } \\
\text { standards for all } \\
\text { appropriate frontage } \\
\text { subdivisions, major } \\
\text { subdivisions, and land } \\
\text { development projects so } \\
\text { as to vary development } \\
\text { patterns and the uniform } \\
\text { look of development } \\
\text { along roads }\end{array}$ & \\
\hline & $\begin{array}{l}\text { Promote 'Planned } \\
\text { Commercial-Recreational } \\
\text { Facilities' that utilize } \\
\text { natural resources based } \\
\text { economic activities such } \\
\text { as farming, wood cutting, } \\
\text { native lumber, tree } \\
\text { farming, orchards, golf } \\
\text { courses, and intensive } \\
\text { crop management. }\end{array}$ & \\
\hline
\end{tabular}


West Greenwich Municipal Protections

\begin{tabular}{|l|l|l|}
\hline $\begin{array}{l}\text { Natural } \\
\text { Resource } \\
\text { Protection }\end{array}$ & $\begin{array}{l}\text { Municipal Resource } \\
\text { Protection }\end{array}$ & Implementation \\
\hline
\end{tabular}

\begin{tabular}{|c|c|c|}
\hline $\begin{array}{l}\text { Land } \\
\text { Conservation }\end{array}$ & & \\
\hline $\begin{array}{l}\text { Farmland } \\
\text { Preservation }\end{array}$ & & \\
\hline Zoning Regulations & & \\
\hline Site Design & $\begin{array}{l}\text { Site Design Standards (calls for } \\
\text { specific areas to be preserved as } \\
\text { open space including agricultural } \\
\text { lands) } \\
\text { Criteria for Review--3 to } 5 \text { lot } \\
\text { minor subdivision (includes cluster } \\
\text { provisions for preservation of } \\
\text { prime farmland or farmland of } \\
\text { statewide importance) }\end{array}$ & $>$ Not implemented \\
\hline $\begin{array}{l}\text { Open Space } \\
\text { Zoning }\end{array}$ & $\begin{array}{l}\text { - Recreational Facilities allowed by } \\
\text { "special use permit" }\end{array}$ & \\
\hline $\begin{array}{l}\text { Open Space } \\
\text { Preservation }\end{array}$ & & \\
\hline $\begin{array}{l}\text { Cluster } \\
\text { Development, } \\
\text { Residential } \\
\text { Compounds }\end{array}$ & & \\
\hline Large Lot Zoning & - Rural, Farming, Residential (RFR 2) & \\
\hline $\begin{array}{l}\text { Land Unsuitable } \\
\text { for Development }\end{array}$ & $\begin{array}{l}\text { Lands Unsuitable for Development } \\
\text { (shall not be counted toward the } \\
\text { minimum lot size requirements; it may } \\
\text { be included as part of any lot in any } \\
\text { subdivision or land development } \\
\text { project; provided that tand unsuitable } \\
\text { for development shall not exceed } 30 \% \\
\text { of the minimum lot size required in the } \\
\text { zoning ordinance--freshwater wetlands, } \\
\text { except that area of perimeter wethand } \\
\text { within } 50 \text { feet of the edge of any bog, } \\
\text { marsh, swamp or pond; or any } \\
\text { applicalle en } 100 \text { foot or } 200 \text { foot } \\
\text { riverbank wetlands; areas within a } 100 \\
\text { year flood zone; land within any publicly } \\
\text { or privately held easement on which } \\
\text { above ground utilities, including but not } \\
\text { limited to electrical transmission lines; } \\
\text { areas which exceed } 15 \% \text { slope) }\end{array}$ & $\begin{array}{l}\text { It is subtracted from the buildable } \\
\text { acreage. } 11 / 4 \text { acre of a } 2 \text {-acre lot } \\
\text { must be unconstrained land. }\end{array}$ \\
\hline $\begin{array}{l}\text { Dedication of Land } \\
\text { for Public Purposes }\end{array}$ & - 2,000 square feet per lot & \\
\hline Site Design & $\begin{array}{l}\text { - Site Design Standards (call for } \\
\text { specific areas to be preserved as } \\
\text { open space) }\end{array}$ & $>$ Not implemented \\
\hline
\end{tabular}


West Greenwich Municipal Protections

\begin{tabular}{|l|l|l|}
\hline $\begin{array}{l}\text { Natural } \\
\text { Resource } \\
\text { Protection }\end{array}$ & $\begin{array}{l}\text { Municipal Resource } \\
\text { Protection }\end{array}$ & Implementation \\
\hline
\end{tabular}

\begin{tabular}{|c|c|c|}
\hline $\begin{array}{l}\text { Natural } \\
\text { Resource } \\
\text { Protection }\end{array}$ & & \\
\hline \multicolumn{3}{|l|}{ Wetlands } \\
\hline $\begin{array}{l}\text { Erosion and } \\
\text { Sediment Control } \\
\text { Plan }\end{array}$ & $\begin{array}{l}\text { Required for all non-contiguous } \\
\text { parcels }\end{array}$ & \\
\hline \multicolumn{3}{|l|}{ Protection District } \\
\hline Setbacks & $\begin{array}{l}\text { ISDS Setback Requirements } \\
\text { (facilities which are designed to } \\
\text { leach liquid wastes into the soil } \\
\text { shall be located not less than } 200 \\
\text { feet from the edge of any pond or } \\
\text { stream) zo }\end{array}$ & $\begin{array}{l}\text { The Town has a } 200 \text {-foot set- } \\
\text { back from any water body. }\end{array}$ \\
\hline $\begin{array}{l}\text { Land Unsuitable for } \\
\text { Development }\end{array}$ & - Land Unsuitable for Development & Adhered to \\
\hline $\begin{array}{l}\text { Environmental } \\
\text { Analysis/Impact } \\
\text { Analysis }\end{array}$ & $\begin{array}{l}\text { - EIS (may be required if there is a } \\
\text { reasonable expectation that the } \\
\text { proposed development will have a } \\
\text { significant negative impact on } \\
\text { natural systems) }\end{array}$ & $\begin{array}{l}\text { The Conservation Commission } \\
\text { reviews } \\
\text { The Town will require an EIS for } \\
\text { large parcels }\end{array}$ \\
\hline Site Design & $\begin{array}{l}\text { Site Design Standards (calls for } \\
\text { specific areas to be preserved as } \\
\text { open space including wetlands) } \\
\text { - Site Analysis }\end{array}$ & $\begin{array}{l}\text { See "land unsuitable for } \\
\text { development" }\end{array}$ \\
\hline Site Plan Review & $\begin{array}{l}\text { Site Plan Review (development shall } \\
\text { result in minimal degradation of unique } \\
\text { or irreplaceable land types; minimal } \\
\text { adverse impact upon the critical areas } \\
\text { such as streams, wetlands, areas of } \\
\text { aquifer recharge and discharge, steep } \\
\text { slopes, highly erodible soils; areas with } \\
\text { a high water table, mature stands of } \\
\text { vegetation and extraordinary wildlife } \\
\text { nesting, feeding or breeding grounds) } \\
\text { zo }\end{array}$ & $\begin{array}{l}\text { All water bodies have a } 200 \text {-foot } \\
\text { buffer } \\
\text { The town does not recognize } \\
\text { DEM's Natural Heritage Program } \\
\text { (according to the planner) }\end{array}$ \\
\hline $\begin{array}{l}\text { Performance } \\
\text { Standards }\end{array}$ & $\begin{array}{l}\text { - Industrial Site and Performance } \\
\text { Standards }\end{array}$ & \\
\hline
\end{tabular}




\section{West Greenwich Municipal Protections}

\begin{tabular}{|l|l|l|}
\hline $\begin{array}{l}\text { Natural } \\
\text { Resource } \\
\text { Protection }\end{array}$ & $\begin{array}{l}\text { Municipal Resource } \\
\text { Protection }\end{array}$ & Implementation \\
\hline
\end{tabular}

\begin{tabular}{|c|c|c|}
\hline $\begin{array}{l}\text { Watercourses/ } \\
\text { Surface Waters }\end{array}$ & & \\
\hline $\begin{array}{l}\text { Erosion and } \\
\text { Sediment Control } \\
\text { Plan }\end{array}$ & - Required & \\
\hline \multicolumn{3}{|l|}{ Protection District } \\
\hline $\begin{array}{l}\text { Environmental } \\
\text { Analysis/Impact } \\
\text { Statement }\end{array}$ & $\begin{array}{l}\text { EIS (may be required if there is a } \\
\text { reasonable expectation that the } \\
\text { proposed development will have a } \\
\text { significant negative impact on } \\
\text { natural systems) }\end{array}$ & $\begin{array}{l}\text { The Conservation Commission } \\
\text { reviews } \\
\text { The Town will require an EIS for } \\
\text { large parcels }\end{array}$ \\
\hline Setbacks & $\begin{array}{l}\text { ISDS Setback Requirements } \\
\text { (facilities which are designed to } \\
\text { leach liquid wastes into the soil } \\
\text { shall be located not less than } 200 \\
\text { feet from the edge of any pond or } \\
\text { strcam) zo }\end{array}$ & $\begin{array}{l}\text { The Town has a } 200 \text {-foot setback } \\
\text { from any water body. }\end{array}$ \\
\hline Site Design & - Site Analysis & \\
\hline Site Plan Review & $\begin{array}{l}\text { Site Plan Revicw (development } \\
\text { shall result in minimal adverse } \\
\text { impact upon critical areas such as } \\
\text { streams...) }\end{array}$ & \\
\hline \multicolumn{3}{|l|}{$\begin{array}{l}\text { Performance } \\
\text { Standards }\end{array}$} \\
\hline Other & & \\
\hline
\end{tabular}




\section{West Greenwich Municipal Protections}

\begin{tabular}{|l|l|l|}
\hline $\begin{array}{l}\text { Natural } \\
\text { Resource } \\
\text { Protection }\end{array}$ & $\begin{array}{l}\text { Municipal Resource } \\
\text { Protection }\end{array}$ & Implementation \\
\hline
\end{tabular}

\begin{tabular}{|c|c|c|}
\hline $\begin{array}{l}\text { Groundwater/ } \\
\text { Recharge Areas }\end{array}$ & & \\
\hline \multicolumn{3}{|l|}{ Protection District } \\
\hline $\begin{array}{l}\text { Environmental } \\
\text { Analysis/Impact } \\
\text { Statement }\end{array}$ & - $\quad$ EIS may be required & $\begin{array}{l}\text { The Town Planner is unaware of } \\
\text { groundwater in West Greenwich }\end{array}$ \\
\hline \multicolumn{3}{|l|}{ Setbacks } \\
\hline Site Design & $\begin{array}{l}\text { Site Design Standards (state that } \\
\text { development should be laid out to } \\
\text { avoid adversely affecting } \\
\text { groundwater and aquifer recharge } \\
\text { and to avoid unnecessary } \\
\text { impervious cover) } \\
\text { - Site Analysis }\end{array}$ & \\
\hline Site Plan Review & $\begin{array}{l}\text { Site Plan Review (development } \\
\text { shall result in minimum } \\
\text { degradation of... areas of aquifer } \\
\text { recharge and discharge; drainage } \\
\text { control should preserve existing } \\
\text { natural drainage patterns and } \\
\text { wetlands; and enhance } \\
\text { groundwater recharge areas) zo }\end{array}$ & \\
\hline \multicolumn{3}{|l|}{ Other } \\
\hline \multicolumn{3}{|l|}{ Floodplains } \\
\hline \multicolumn{3}{|l|}{ Protection District } \\
\hline $\begin{array}{l}\text { Land Unsuitable for } \\
\text { Development }\end{array}$ & - Land Unsuitable for Development & \\
\hline \multicolumn{3}{|l|}{$\begin{array}{l}\text { Environmental } \\
\text { Analysis/Impact } \\
\text { Statement }\end{array}$} \\
\hline \multicolumn{3}{|l|}{ Setbacks } \\
\hline Site Design & $\begin{array}{l}\text { - Site Design Standards (call for } \\
\text { specific areas to be preserved as } \\
\text { open space including lands in the } \\
\text { floodplain) } \\
\text { - Site Analysis }\end{array}$ & \\
\hline \multicolumn{3}{|l|}{ Site Plan Review } \\
\hline Other & $\begin{array}{l}\text { Design and Public Improvement } \\
\text { Standards (state that development } \\
\text { should be laid out to prevent flooding; } \\
\text { also, the Planning Board shall examine } \\
\text { each proposed subdivision to ensure } \\
\text { that potential flood damage is } \\
\text { minimized, public utilities and facilities } \\
\text { are elevated and that adequate drainage } \\
\text { is provided) }\end{array}$ & \\
\hline
\end{tabular}


West Greenwich Municipal Protections

\begin{tabular}{|l|l|l|}
\hline $\begin{array}{l}\text { Natural } \\
\text { Resource } \\
\text { Protection }\end{array}$ & $\begin{array}{l}\text { Municipal Resource } \\
\text { Protection }\end{array}$ & Implementation \\
\hline
\end{tabular}

\begin{tabular}{|c|c|c|}
\hline Topography & & \\
\hline \multicolumn{3}{|l|}{$\begin{array}{l}\text { Ension and Sediment } \\
\text { Control Plan }\end{array}$} \\
\hline $\begin{array}{l}\text { Land Unsuitable for } \\
\text { Development }\end{array}$ & $\begin{array}{l}\text { Land Unsuitable for Development } \\
\text { (areas that exceed 15\% slope) }\end{array}$ & \\
\hline Site Design & $\begin{array}{l}\text { - Site Design Standards ( slopes } \\
\text { exceeding } 15 \% \text { preferred } \\
\text { preservation as open space) }\end{array}$ & \\
\hline Site Plan Review & $\begin{array}{l}\text { Site Plan Review (development } \\
\text { shall result in minimal degradation } \\
\text { of unique or irreplaceable land } \\
\text { types; minimal adverse impact } \\
\text { upon the critical areas such as... } \\
\text { steep slopes, highly erodible soils; } \\
\text { areas with a high water table, } \\
\text { mature stands of vegetation and } \\
\text { extraordinary wildlife nesting, } \\
\text { feeding or breeding grounds) zo }\end{array}$ & \\
\hline \multicolumn{3}{|l|}{$\begin{array}{l}\text { Rare Species/ } \\
\text { Critical Habitat }\end{array}$} \\
\hline \multicolumn{3}{|l|}{ Protection District } \\
\hline $\begin{array}{l}\text { Environmental } \\
\text { Analysis/Impact } \\
\text { Statement }\end{array}$ & - $\quad$ EIS may be required & \\
\hline \multicolumn{3}{|l|}{ Setbackes } \\
\hline Site Design & $\begin{array}{l}\text { - Site Design Standards (call for } \\
\text { specific areas to be preserved as } \\
\text { open space including habitats of } \\
\text { endangered wildlife) } \\
\text { - Site Analysis }\end{array}$ & $\begin{array}{l}\text { The town does not recognize } \\
\text { DEM's Natural Heritage Program }\end{array}$ \\
\hline Site Plan Revien & $\begin{array}{l}\text { Site Plan Review (development } \\
\text { shall result in minimal adverse } \\
\text { impact upon... areas of } \\
\text { extraordinary wildlife nesting, } \\
\text { feeding or breeding grounds) zo }\end{array}$ & \\
\hline
\end{tabular}


West Greenwich Municipal Protections

\begin{tabular}{|l|l|l|}
\hline $\begin{array}{l}\text { Natural } \\
\text { Resource } \\
\text { Protection }\end{array}$ & $\begin{array}{l}\text { Municipal Resource } \\
\text { Protection }\end{array}$ & Implementation \\
\hline
\end{tabular}

\begin{tabular}{|c|c|c|}
\hline $\begin{array}{l}\text { Trees/ } \\
\text { Woodlands }\end{array}$ & & \\
\hline $\begin{array}{l}\text { Erosion and Sediment } \\
\text { Control Plan }\end{array}$ & $\begin{array}{l}\text { Drainage and Erosion and } \\
\text { Sediment Control Standards } \\
\text { (wherever feasible natural } \\
\text { vegetation shall be retained and } \\
\text { protected) }\end{array}$ & \\
\hline Site Design & $\begin{array}{l}\text { Lot Development Standards } \\
\text { (preservation of unique natural } \\
\text { and/or historic features such as } \\
\text { trees or stone walls may be } \\
\text { required for } 2 \text { lot minor } \\
\text { subdivisions) } \\
\text { - Site Design Standards (call for } \\
\text { specific areas to be preserved as } \\
\text { open space including significant } \\
\text { trees or stands of trees, or other } \\
\text { vegetative species that are rare to } \\
\text { the area or are of particular } \\
\text { horticultural or landscape value; } \\
\text { development should be laid out to } \\
\text { reduce cut and fill) } \\
\text { Site Analysis }\end{array}$ & \\
\hline Site Plan Review & $\begin{array}{l}\text { - Site Plan Review (The landscape } \\
\text { shall be preserved in its natural } \\
\text { state, insofar as environmentally } \\
\text { desirable, by minimizing tree and } \\
\text { soil removal) zo }\end{array}$ & \\
\hline Other & $\begin{array}{l}\text { Design and Public Improvement } \\
\text { Standards (street design standards } \\
\text { call for conservation of existing } \\
\text { trees where feasible) }\end{array}$ & \\
\hline
\end{tabular}




\section{Summary}

Westerly is the most urbanized town in the study area. The Town is slowly modernizing its planning capacity, but is not really focused on the concerns in this study. For example, the Town is more concerned with locating and purchasing land for municipal needs, such as schools and recreational areas. Most residential and commercial development in Westerly is in-fill development. In regard to natural resource protection, the Town is primarily concerned with protecting its groundwater resources, whether the development is in-fill or not. However, the Town needs new maps based on parcel information to adequately protect local groundwater.

Westerly has not adopted most of its comprehensive plan objectives. The new town planner will be updating the plan's objectives to better reflect the unique, urban ecological issues facing the Town. The Town's development regulations provide very few provisions for the protection of natural resources. The Town does not require an environmental analysis, and the site design standards provide minimal guidance for protecting the natural features of the site. The planning board will encourage cluster design to preserve open space and protect natural resources. The Town also has a development plan review ordinance, with strict standards for protecting drinking water supplies and coastal vegetation. The planning board is in the process of reviewing a new site analysis provision, which would require developers to address the environmental impacts of the development proposal.

\section{Planning Department}

Westerly employs one half-time planner, who is actually new to the Town. Consequently, the interview for this study resulted in a limited amount of information. However, the planner does have a background in, and commitment to, environmental management. $\mathrm{He}$ is also a half-time town planner in Richmond. 
The town planner spends an equal amount of time consulting with the town council, planning board, and zoning board of review. He also has a working relationship with the town manager. The conservation commission also lends support in reviewing development proposals. The Town can require an outside environmental consultant to review development proposals. The town planner is working to increase in-house GIS capacity and site analysis capabilities, as well as updating the comprehensive plan so that it will be a useful document for guiding future development.

Primary planning capacity limitations include GIS and site analysis, research assistance in updating the comprehensive plan, and effective training for council, board and commission members.

\section{Comprehensive Plan Objectives}

The majority of the comprehensive plan objectives have not been adopted, with the exception of the development plan review ordinance and the aquifer protection overlay district. Plan updates need to focus far more on protecting the Town's extensive and fragile coastal resources. The plan also needs to include clear policy objectives on protecting the Town's water resources.

\section{Site Analysis}

Because the planner was new to the Town, limited information could be provided on this subject. The Town appears to rely primarily on the developer to provide important site information. The planning board is working on adopting a site analysis requirement for more in-depth site information. An outside consultant also may be requested if the development endangers the Town's drinking water supplies or coastal environment. 


\section{Zoning and Subdivision Regulations}

\section{Zoning Ordinances}

- Farmland Zoning-none

- Residential Cluster Development-Residential cluster development is permitted in the RR-60, LDR-43, LDR-40 and MDR-30 zoning districts. The developer must demonstrate clustering would be a better use of the land than a conventional subdivision, and there is no minimum open space requirement. The planning board may encourage a cluster design.

- Large Lot Residential Zoning-none

- Overlay Districts-Aquifer Protection Overlay District. This ordinance is comprehensive and strictly implemented

- Site Plan Review-The Town has a development plan review ordinance with strict standards for protecting surface and groundwater, coastal vegetation and public access.

- Performance Standards-The Town has a "Hazardous Waste Management Facility Siting Requirement" ordinance with a 1,000 foot setback from environmentally sensitive areas.

\section{Subdivision and Land Development Regulations}

- Land Unsuitable for Development-This regulation includes freshwater wetlands, coastal wetlands, land within an easement, areas within the 100 year flood zone and areas with soils that exceed $15 \%$ slope.

- Environmental Analysis-The Town has a very non-specific impact statement requirement.

- Erosion and Sediment Control-An erosion and sediment control plan is required for all major subdivisions and land developments, and for all development occurring in environmentally sensitive areas. The town engineer reviews the plans, however, little monitoring is done.

- Site Design Standards-The Town has a fairly comprehensive list of natural resources that should be preserved as open space in the design of the site. However, without a site analysis requirement and without the flexibility of a cluster design, the Town has no real way of implementing these standards. 


\section{Westerly Comprehensive Plan Matrix}

\begin{tabular}{|l|l|l|}
\hline Issue Area & $\begin{array}{l}\text { Comprehensive Planning } \\
\text { Objective }\end{array}$ & Implementation \\
\hline
\end{tabular}

\begin{tabular}{|c|c|c|}
\hline $\begin{array}{l}\text { Farmland } \\
\text { Preservation }\end{array}$ & & \\
\hline $\begin{array}{l}\text { Open Space } \\
\text { Zoning }\end{array}$ & & \\
\hline $\begin{array}{l}\text { Open Space } \\
\text { Preservation }\end{array}$ & & \\
\hline & $\begin{array}{l}\text { Wherever possible, link } \\
\text { together key open space } \\
\text { parcels to increase their } \\
\text { value using a variety of } \\
\text { techniques and functional } \\
\text { components }\end{array}$ & Not adopted \\
\hline & $\begin{array}{l}\text { Develop a source of } \\
\text { revenue to acquire and } \\
\text { maintain open space }\end{array}$ & $>$ Only for municipal land use needs \\
\hline & $\begin{array}{l}\text { Acquire key potential Open } \\
\text { Space Parcels }\end{array}$ & $>$ Not adopted \\
\hline & $\begin{array}{l}\text { Consider establishing a } \\
\text { Natural Resources } \\
\text { Department to assist the } \\
\text { Conservation Commission } \\
\text { address the management of } \\
\text { the Town's Natural } \\
\text { Resources }\end{array}$ & $>$ Not adopted \\
\hline & $\begin{array}{l}\text { Encourage the use of cluster } \\
\text { zoning to create open space } \\
\text { and recreation areas }\end{array}$ & $\begin{array}{l}\text { The planning board encourages cluster } \\
\text { designs where appropriate }\end{array}$ \\
\hline & $\begin{array}{l}\text { Acquire critical areas for } \\
\text { protection purposes (Capital } \\
\text { Improvement) }\end{array}$ & $>$ Not adopted \\
\hline
\end{tabular}




\section{Westerly Comprehensive Plan Matrix}

\begin{tabular}{|l|l|l|}
\hline Issue Area & $\begin{array}{l}\text { Comprehensive Planning } \\
\text { Objective }\end{array}$ & Implementation \\
\hline
\end{tabular}

\begin{tabular}{|c|c|c|}
\hline $\begin{array}{l}\text { Natural } \\
\text { Resource } \\
\text { Protection }\end{array}$ & & \\
\hline \multicolumn{3}{|l|}{ Wetlands } \\
\hline & $\begin{array}{l}\text { Insure adequate 'vegetated } \\
\text { buffers' (setbacks) are } \\
\text { required between upland } \\
\text { development and wetland } \\
\text { resource areas }\end{array}$ & Relies on DEM's standards \\
\hline & $\begin{array}{l}\text { Develop Performance } \\
\text { Standards for the following: } \\
\text { stormwater run-off, erosion } \\
\text { and sedimentation controls, } \\
\text { vegetated buffers, land } \\
\text { clearing activities, ISDS, and } \\
\text { wetlands protection }\end{array}$ & Not adopted \\
\hline \multicolumn{3}{|l|}{$\begin{array}{l}\text { Watercourse/ } \\
\text { Surface } \\
\text { Waters } \\
\end{array}$} \\
\hline & $\begin{array}{l}\text { - Adopt a River Corridor } \\
\text { Overlay }\end{array}$ & $\begin{array}{l}\text { Reserved in zoning ordinance (needs } \\
\text { constituency to write ordinance) }\end{array}$ \\
\hline & $\begin{array}{l}\text { Develop Performance } \\
\text { Standards for the following: } \\
\text { stormwater run-off, erosion } \\
\text { and sedimentation controls, } \\
\text { vegetated buffers, land } \\
\text { clearing activities, ISDS, and } \\
\text { wetlands protection }\end{array}$ & Not adopted \\
\hline & $\begin{array}{l}\text { Incorporate a Site Plan } \\
\text { Review process into the } \\
\text { ordinance to provide for } \\
\text { detailed review of certain } \\
\text { types of activities (i.e., those } \\
\text { which exceed certain square } \\
\text { footage thresholds or } \\
\text { parking requirements) and } \\
\text { those which occur in } \\
\text { "critical areas' such as the } \\
\text { Route } 1 \text { and Pawcatuck } \\
\text { River corridors }\end{array}$ & $>$ Adopted \\
\hline
\end{tabular}




\begin{tabular}{|l|l|l|}
\hline Issue Area & $\begin{array}{l}\text { Comprehensive Planning } \\
\text { Objective }\end{array}$ & Implementation \\
\hline
\end{tabular}

\begin{tabular}{|c|c|c|}
\hline $\begin{array}{l}\text { Groundwater } \\
\text { /Recharge } \\
\text { Areas }\end{array}$ & & \\
\hline & $\begin{array}{l}\text { Protect the aquifers that } \\
\text { contribute to the Town } \\
\text { wells from potential } \\
\text { contamination by strict } \\
\text { regulation of threats to } \\
\text { ground water quality and a } \\
\text { program of continuous } \\
\text { monitoring of these threats } \\
\text { to ground water quality }\end{array}$ & $\begin{array}{l}\text { Adopted "Aquifer Protection Overlay } \\
\text { District" }\end{array}$ \\
\hline & $\begin{array}{l}\text { Adopt an Aquifer } \\
\text { Protection Overlay }\end{array}$ & $>$ Adopted \\
\hline & $\begin{array}{l}\text { Increase inspection and } \\
\text { enforcement procedures to } \\
\text { insure that all development } \\
\text { is constructed in accordance } \\
\text { with the conditions } \\
\text { established at the time of } \\
\text { approval }\end{array}$ & $>\quad$ No \\
\hline & $\begin{array}{l}\text { - Make water conservation a } \\
\text { high priority for the Town }\end{array}$ & $\begin{array}{l}\text { The Town hands-out water kits every } \\
\text { summer and will institute watering bands }\end{array}$ \\
\hline & $\begin{array}{l}\text { Establish a Wastewater } \\
\text { Management District to } \\
\text { ensure ISDS performance } \\
\text { and maintenance }\end{array}$ & $\begin{array}{l}\text { Not adopted } \\
\quad \text { Most of the Town is sewered }\end{array}$ \\
\hline Floodplains & & \\
\hline & - Flood Hazard Overlay & $D$ Adopted \\
\hline $\begin{array}{l}\text { Coastal } \\
\text { Features }\end{array}$ & & \\
\hline & $\begin{array}{l}\text { Develop land use standards } \\
\text { (such as a Salt Ponds Overlay } \\
\text { Protection District) that reflect } \\
\text { the sensitive nature of the } \\
\text { coastal environment including } \\
\text { coordination with the policies } \\
\text { of SAMP and CRMC for } \\
\text { coastal ponds. }\end{array}$ & Relies on CRMC to set standards \\
\hline & $\begin{array}{l}\text { Through a combination of } \\
\text { new density requirements, } \\
\text { performance standards and } \\
\text { revisions to the Zoning } \\
\text { Map, the Town can achieve } \\
\text { greater long-term protection } \\
\text { of its coastal resources }\end{array}$ & $\begin{array}{l}\text { The Town adopted cluster provisions } \\
\text { Maybe rezoned some land }\end{array}$ \\
\hline
\end{tabular}




\section{\begin{tabular}{|l|l|l|}
\hline Issue Area & Comprehensive Planning & Implementation
\end{tabular}}

Objective

\begin{tabular}{|c|c|c|}
\hline $\begin{array}{l}\text { Coastal } \\
\text { Features } \\
\text { (continued) }\end{array}$ & & \\
\hline & $\begin{array}{l}\text { Develop a water quality } \\
\text { monitoring program for } \\
\text { inland and coastal waters to } \\
\text { gauge the effectiveness of } \\
\text { protection measures and } \\
\text { serve as an early warning } \\
\text { system in the event of } \\
\text { contamination }\end{array}$ & $>$ Not adopted \\
\hline & $\begin{array}{l}\text { - Integrate the } \\
\text { recommendations of the } \\
\text { Pawcatuck River Estuary } \\
\text { Management Project } \\
\text { (Harbor Management Plan) } \\
\text { into the Town's land use } \\
\text { regulations and } \\
\text { enforcement/management } \\
\text { programs where appropriate }\end{array}$ & $>$ Not adopted \\
\hline Topography & & \\
\hline $\begin{array}{l}\text { Rare Species/ } \\
\text { Critical } \\
\text { Habitat }\end{array}$ & & \\
\hline & $\begin{array}{l}\text { Retain open spaces that are } \\
\text { large enough to serve a } \\
\text { variety of purposes } \\
\text { including recreation, wildlife } \\
\text { habitat, pollution abatement } \\
\text { and as buffers to existing } \\
\text { development }\end{array}$ & Not adopted \\
\hline & $\begin{array}{l}\text { Insure the protection of rare } \\
\text { species habitat by } \\
\text { monitoring development } \\
\text { projects within or adjacent } \\
\text { to identified sites and } \\
\text { requiring restrictions on } \\
\text { activities which may be } \\
\text { deemed harmful to these } \\
\text { environments }\end{array}$ & $>$ Not adopted \\
\hline & $\begin{array}{l}\text { Strengthen the management } \\
\text { programs for Napatree } \\
\text { Point and Maschaug beach } \\
\text { to control recreation } \\
\text { overuse and natural } \\
\text { predation of rare shorebirds }\end{array}$ & $D$ Yes \\
\hline
\end{tabular}




\begin{tabular}{|l|l|l|}
\hline Issue Area & $\begin{array}{l}\text { Comprehensive Planning } \\
\text { Objective }\end{array}$ & Implementation \\
\hline
\end{tabular}

\begin{tabular}{|c|c|c|}
\hline $\begin{array}{l}\text { Trees/ } \\
\text { Woodlands }\end{array}$ & & \\
\hline & $\begin{array}{l}\text { Maintain and enhance the } \\
\text { aesthetic quality of the } \\
\text { Town by protecting and } \\
\text { caring for existing trees and } \\
\text { the planting of new trees } \\
\text { along roadways and on } \\
\text { other publicly owned } \\
\text { property }\end{array}$ & $\begin{array}{l}\text { Regulations adopted for trees in public } \\
\text { right of way }\end{array}$ \\
\hline $\begin{array}{l}\text { Cultural and } \\
\text { Historic } \\
\text { Resources }\end{array}$ & & \\
\hline $\begin{array}{l}\text { Village/Rural } \\
\text { Character }\end{array}$ & & \\
\hline & $\begin{array}{l}\text { Integrate new commercial } \\
\text { and residential development } \\
\text { within established older } \\
\text { neighborhoods in a manner } \\
\text { that will preserve and } \\
\text { enhance historic and } \\
\text { cultural resources }\end{array}$ & \\
\hline & $\begin{array}{l}\text { Maintain and enhance the } \\
\text { aesthetic quality of the } \\
\text { Town by protecting and } \\
\text { caring for existing trees and } \\
\text { the planting of new trees } \\
\text { along roadways and on } \\
\text { other publicly owned } \\
\text { property }\end{array}$ & \\
\hline & $\begin{array}{l}\text { Promote less dispersed site } \\
\text { design and avoid "sprawl" } \\
\text { by encouraging housing } \\
\text { development consistent } \\
\text { with policies of water } \\
\text { resource protection and } \\
\text { preservation of the Town's } \\
\text { open space and rural } \\
\text { character }\end{array}$ & \\
\hline
\end{tabular}


Westerly Comprehensive Plan Matrix

\begin{tabular}{|l|l|l|}
\hline Issue Area & $\begin{array}{l}\text { Comprehensive Planning } \\
\text { Objective }\end{array}$ & Implementation \\
\hline
\end{tabular}

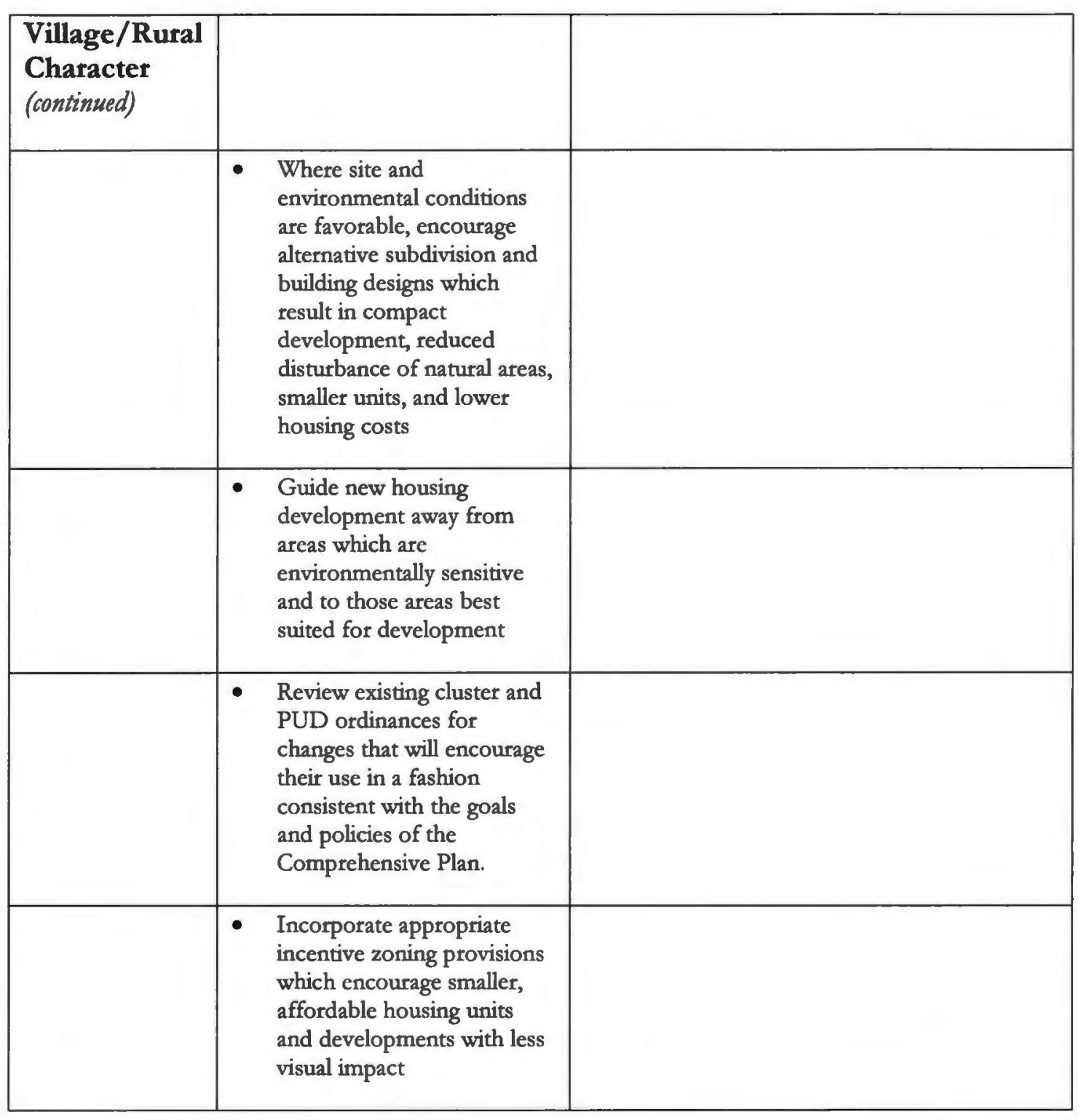


Westerly Municipal Protections

\begin{tabular}{|l|l|l|}
\hline $\begin{array}{l}\text { Natural } \\
\text { Resource } \\
\text { Protection }\end{array}$ & Municipal Protection & Implementation \\
\hline
\end{tabular}

\begin{tabular}{|c|c|c|}
\hline $\begin{array}{l}\text { Land } \\
\text { Conservation }\end{array}$ & & \\
\hline $\begin{array}{l}\text { Farmland } \\
\text { Preservation }\end{array}$ & & \\
\hline Zoning Regulations & & \\
\hline Site Design & $\begin{array}{l}\text { - Site Design Standards (preferred } \\
\text { preservation of agricultural land in site } \\
\text { design) }\end{array}$ & \\
\hline $\begin{array}{l}\text { Open Space } \\
\text { Zoning }\end{array}$ & & \\
\hline & $\begin{array}{l}\text { - Permitted uses by "special use permit" } \\
\text { include: Public Parks and Recreation, } \\
\text { Golf Courses. Municipal Buildings and } \\
\text { Cemeteries }\end{array}$ & \\
\hline $\begin{array}{l}\text { Open Space } \\
\text { Preservation }\end{array}$ & & \\
\hline $\begin{array}{l}\text { Cluster } \\
\text { Development, } \\
\text { Residential } \\
\text { Compounds, Large } \\
\text { Lot Zoning }\end{array}$ & $\begin{array}{l}\text { Residential cluster development is } \\
\text { permitted in the RR-60, LDR-43, } \\
\text { LDR-40 and MDR-30 zoning districts } \\
\text { (minimum land area is } 10 \text { acres; if it } \\
\text { includes private roads, } 25 \text { acres is } \\
\text { required) zo } \\
\text { Residential cluster development } \\
\text { (developer must demonstrate } \\
\text { clustering would be a better use of the } \\
\text { land than a conventional subdivision } \\
\text { (no minimum open space } \\
\text { requirement) zo }\end{array}$ & $\begin{array}{l}\text { Planning Board will propose a } \\
\text { cluster designs }\end{array}$ \\
\hline $\begin{array}{l}\text { Land Unsuitable } \\
\text { for Development }\end{array}$ & $\begin{array}{l}\text { Land Unsuitable for Development } \\
\text { (may be deducted from the minimum } \\
\text { building acreage of the parcel-- } \\
\text { freshwater wetlands, coastal wetlands, } \\
\text { land within an easement, areas within } \\
\text { the } 100 \text { year flood zone and areas with } \\
\text { soils that exceed } 15 \% \text { slope) }\end{array}$ & $\begin{array}{l}\text { Land unsuitable for } \\
\text { development is deducted from } \\
\text { the minimum buildable acreage }\end{array}$ \\
\hline $\begin{array}{l}\text { Dedication of Land } \\
\text { for Public Purposes }\end{array}$ & $\begin{array}{l}\text { Dedication of Public Land and } \\
\text { Improvements (see comp.plan) }\end{array}$ & \\
\hline Site Design & $\begin{array}{l}\text { - Site Design Standards (see preferred } \\
\text { areas for preservation) }\end{array}$ & \\
\hline
\end{tabular}


Westerly Municipal Protections

\begin{tabular}{|l|l|l|}
\hline $\begin{array}{l}\text { Natural } \\
\text { Resource } \\
\text { Protection }\end{array}$ & $\begin{array}{l}\text { Municipal Protection } \\
\text { Measure }\end{array}$ & Implementation \\
\hline
\end{tabular}

\begin{tabular}{|l|l|l|}
\hline $\begin{array}{l}\text { Natural } \\
\text { Resource } \\
\text { Protection }\end{array}$ & \\
\hline Wetlands & & \\
\hline $\begin{array}{l}\text { Erosion and } \\
\text { Sediment Control } \\
\text { Plan }\end{array}$ & $\begin{array}{l}\text { Erosion and Sediment Control Plan } \\
\text { (all major development as well as any } \\
\text { development activity within 200 feet } \\
\text { of any wetland or coastal feature) }\end{array}$ & $\begin{array}{l}\text { D Adhered to } \\
\text { Plans are reviewed by town } \\
\text { engineer } \\
\text { Not a lot of monitoring }\end{array}$ \\
\hline Protection District & & \\
\hline Setbacks & & \\
\hline $\begin{array}{l}\text { Land Unsuitable } \\
\text { for Development }\end{array}$ & - Land Unsuitable for Development & \\
\hline $\begin{array}{l}\text { Environmental } \\
\text { Analysis/Impact } \\
\text { Analysis }\end{array}$ & & \\
\hline $\begin{array}{l}\text { Site Design } \\
\text { Site Plan Review }\end{array}$ & Site Design Standards (preferred \\
\hline $\begin{array}{l}\text { Performance } \\
\text { Standards }\end{array}$ & & \\
\hline
\end{tabular}


Westerly Municipal Protections

\begin{tabular}{|l|l|l|}
\hline $\begin{array}{l}\text { Natural } \\
\text { Resource } \\
\text { Protection }\end{array}$ & $\begin{array}{l}\text { Municipal Protection } \\
\text { Measure }\end{array}$ & Implementation \\
\hline
\end{tabular}

\begin{tabular}{|c|c|c|}
\hline $\begin{array}{l}\text { Watercourses/ } \\
\text { Surface Waters }\end{array}$ & & \\
\hline $\begin{array}{l}\text { Erosion and } \\
\text { Sediment Control } \\
\text { Plan }\end{array}$ & $\begin{array}{l}\text { Erosion and Sediment Control } \\
\text { (original boundaries, alignment and } \\
\text { slope of water courses shall be } \\
\text { preserved to the greatest extent } \\
\text { possible) }\end{array}$ & $>$ Town Engineer reviews \\
\hline Protection District & $\begin{array}{l}\text { - } \quad \text { River Corridor Overlay zo } \\
\text { - Salt Pond Overlay zo }\end{array}$ & $\begin{array}{l}\text { There is no River Corridor } \\
\text { Overlay } \\
\text { CRMC reviews development in } \\
\text { coastal zone }\end{array}$ \\
\hline Setbacks & $\begin{array}{l}\text { Hazardous Waste Management Facility } \\
\text { Siting Requirements (prohibited within } \\
1,000 \text { feet of environmentally sensitive } \\
\text { areas) zo }\end{array}$ & Adhered to \\
\hline Site Design & $\begin{array}{l}\text { Site Design Standards (original } \\
\text { boundaries, alignment and slope of } \\
\text { water courses shall be preserved to the } \\
\text { greatest extent possible) }\end{array}$ & Adhered to \\
\hline Site Plan Review & $\begin{array}{l}\text { Development Plan Review (required } \\
\text { for all non-residential uses--a } \\
\text { development plan shall not be } \\
\text { approved if it would result in water } \\
\text { pollution, damage to shoreline } \\
\text { vegetation, or inhibition of public } \\
\text { access) zo }\end{array}$ & Adhered to (see impact rules) \\
\hline \multicolumn{3}{|l|}{$\begin{array}{l}\text { Performance } \\
\text { Standards }\end{array}$} \\
\hline Other & $\begin{array}{l}\text { Stormwater Easement or drainage } \\
\text { right-of-way (required where } \\
\text { development is traversed by a water } \\
\text { course, drainage way, channel or } \\
\text { stream) }\end{array}$ & \\
\hline
\end{tabular}


Westerly Municipal Protections

\begin{tabular}{|l|l|l|}
\hline $\begin{array}{l}\text { Natural } \\
\text { Resource } \\
\text { Protection }\end{array}$ & Municipal Protection & Implementation \\
\hline
\end{tabular}

\begin{tabular}{|c|c|c|}
\hline \multicolumn{3}{|l|}{$\begin{array}{l}\text { Groundwater/ } \\
\text { Recharge Areas }\end{array}$} \\
\hline & $\begin{array}{l}\text { - Groundwater Protection Overlay } \\
\text { District zo }\end{array}$ & $\begin{array}{l}\text { Comprehensive and strictly } \\
\text { adhered to }\end{array}$ \\
\hline \multicolumn{3}{|l|}{$\begin{array}{l}\text { Environmental } \\
\text { Analysis/Impact } \\
\text { Statement }\end{array}$} \\
\hline Setbacks & $\begin{array}{l}\text { - Hazardous Waste Management Facility } \\
\text { Siting Requirements (prohibited within } \\
1,000 \text { feet of environmentally sensitive } \\
\text { areas) zo }\end{array}$ & \\
\hline \multicolumn{3}{|l|}{ Site Design } \\
\hline Site Plan Review & $\begin{array}{l}\text { Development Plan Review (required } \\
\text { for all non-residential uses--a } \\
\text { development plan shall not be } \\
\text { approved if it would result in water } \\
\text { pollution, damage to shoreline } \\
\text { vegetation, or inhibition of public } \\
\text { access) zo }\end{array}$ & $>$ Adhered to (see impact rules) \\
\hline \multicolumn{3}{|l|}{ Other } \\
\hline \multicolumn{3}{|l|}{ Floodplains } \\
\hline Protection District & $\begin{array}{l}\text { Flood Hazard Overlay District (no use } \\
\text { shall be approved which would } \\
\text { adversely affect the capacity of any } \\
\text { drainage facility or system or would } \\
\text { involve alteration of sand dunes, } \\
\text { barrier beaches, and other narural } \\
\text { protective barriers) zo }\end{array}$ & $\begin{array}{l}\text { Developer and land surveyor } \\
\text { must demonstrate prior to } \\
\text { approval }\end{array}$ \\
\hline $\begin{array}{l}\text { Land Unsuitable } \\
\text { for Development }\end{array}$ & - Land Unsuitable for Development & \\
\hline $\begin{array}{l}\text { Environmental } \\
\text { Analysis/Impact } \\
\text { Statement }\end{array}$ & Review Impact rules & \\
\hline \multicolumn{3}{|l|}{ Setbacks } \\
\hline Site Design & $\begin{array}{l}\text { - Site Design Standards (preferred } \\
\text { preservation as open space in site } \\
\text { design) }\end{array}$ & \\
\hline \multicolumn{3}{|l|}{ Site Plan Review } \\
\hline Other & & \\
\hline
\end{tabular}




\section{Westerly Municipal Protections}

\begin{tabular}{|l|l|l|}
\hline $\begin{array}{l}\text { Natural } \\
\text { Resource } \\
\text { Protection }\end{array}$ & $\begin{array}{l}\text { Municipal Protection } \\
\text { Measure }\end{array}$ & Implementation \\
\hline
\end{tabular}

\begin{tabular}{|c|c|c|}
\hline Topography & & \\
\hline $\begin{array}{l}\text { Erosion and } \\
\text { Sediment Control } \\
\text { Plan }\end{array}$ & $\begin{array}{l}\text { Erosion and Sediment Control Plan } \\
\text { (required for all major land } \\
\text { developments/subdivisions and all } \\
\text { subdivisions if slopes are greater than } \\
10 \% \text { ) }\end{array}$ & \\
\hline $\begin{array}{l}\text { Land Unsuitable } \\
\text { for Development }\end{array}$ & $\begin{array}{l}\text { Land Unsuitable for Development } \\
\text { (slopes in excess of } 15 \% \text { ) }\end{array}$ & \\
\hline Site Design & & \\
\hline Site Plan Review & & \\
\hline $\begin{array}{l}\text { Rare Species/ } \\
\text { Critical Habitat }\end{array}$ & & \\
\hline Protection District & & \\
\hline $\begin{array}{l}\text { Environmental } \\
\text { Analysis/Impact } \\
\text { Statement }\end{array}$ & & \\
\hline Setbacks & & \\
\hline Site Design & $\begin{array}{l}\text { - Site Design Standards (preferred } \\
\text { preservation of endangered wildlife } \\
\text { habitat in site design) }\end{array}$ & $\begin{array}{l}\text { Conservation Commission } \\
\text { provides comments to Planning } \\
\text { Board }\end{array}$ \\
\hline Site Plan Review & & \\
\hline $\begin{array}{l}\text { Trees/ } \\
\text { Woodlands }\end{array}$ & & \\
\hline $\begin{array}{l}\text { Erosion and } \\
\text { Sediment Control } \\
\text { Plan }\end{array}$ & $\begin{array}{l}\text { Erosion and Sediment Control (trees } \\
\text { and other existing vegetation shall be } \\
\text { fenced or roped off to protect trees } \\
\text { from construction equipment) }\end{array}$ & \\
\hline Site Design & $\begin{array}{l}\text { Site Design Standards (significant trees } \\
\text { or stands of trees or other vegetative } \\
\text { species that are rare to the area or are } \\
\text { of particular horticultural or landscape } \\
\text { value are preferred areas of } \\
\text { preservation in site design) }\end{array}$ & \\
\hline Site Plan Review & & \\
\hline Other & $\begin{array}{l}\text { - Unlawful Cutting of Trees or Shrubs } \\
\text { (unless authorized in writing by the } \\
\text { Public Works Director, trees or other } \\
\text { vegetation cannot be removed to } \\
\text { increase the visibility of a sign) } \\
\text { - Public Improvement Standards, } \\
\text { Street Trees p.33 } \\
\end{array}$ & \\
\hline
\end{tabular}


Westerly Municipal Protections

\begin{tabular}{|l|l|l|}
\hline $\begin{array}{l}\text { Natural } \\
\text { Resource } \\
\text { Protection }\end{array}$ & $\begin{array}{l}\text { Municipal Protection } \\
\text { Measure }\end{array}$ & Implementation \\
\hline
\end{tabular}

\begin{tabular}{|c|c|c|}
\hline $\begin{array}{l}\text { Coastal } \\
\text { Features }\end{array}$ & & \\
\hline $\begin{array}{l}\text { Erosion and } \\
\text { Sediment Control }\end{array}$ & $\begin{array}{l}\text { Erosion and Sediment Control Plan } \\
\text { (required for all development within } \\
200 \text { feet of any wetland or coastal } \\
\text { feature) }\end{array}$ & $\begin{array}{l}\text { Town Engineer reviews } \\
\text { Little monitoring is done }\end{array}$ \\
\hline $\begin{array}{l}\text { Overlay Protection } \\
\text { District }\end{array}$ & $\begin{array}{l}\text { - Salt Pond Overlay zo } \\
\text { Flood Hazard Overlay District (no use } \\
\text { shall be approved which would } \\
\text { adversely affect the capacity of any } \\
\text { drainage facility or system or would } \\
\text { involve alteration of sand dunes, } \\
\text { barrier beaches, and other natural } \\
\text { protective barriers) zo }\end{array}$ & $\begin{array}{l}\text { CRMC reviews development } \\
\text { proposals } \\
\text { Developer and land surveyor } \\
\text { must demonstrate before } \\
\text { approval }\end{array}$ \\
\hline $\begin{array}{l}\text { Environmental } \\
\text { Analysis/Impact } \\
\text { Statement }\end{array}$ & & \\
\hline Setbacks & $\begin{array}{l}\text { - Hazardous Waste Management Facility } \\
\text { Siting Requirements (prohibited within } \\
1,000 \text { feet of environmentally sensitive } \\
\text { areas) zo }\end{array}$ & \\
\hline $\begin{array}{l}\text { Land Unsuitable } \\
\text { for Development }\end{array}$ & $\begin{array}{l}\text { Coastal wetlands and areas within the } \\
100 \text { year flood zone are considered } \\
\text { unsuitable for development }\end{array}$ & \\
\hline Site Design & $\begin{array}{l}\text { - Site Design Standards (preferred } \\
\text { preservation of coastal features in site } \\
\text { design) }\end{array}$ & \\
\hline Site Plan Review & $\begin{array}{l}\text { Development Plan Review (required } \\
\text { for all non-residential uses--a } \\
\text { development plan shall not be } \\
\text { approved if it would result in water } \\
\text { pollution, damage to shoreline } \\
\text { vegetation, or inhibition of public } \\
\text { access) zo }\end{array}$ & \\
\hline Other & & \\
\hline
\end{tabular}


Westerly Municipal Protections

\begin{tabular}{|l|l|l|}
\hline $\begin{array}{l}\text { Natural } \\
\text { Resource } \\
\text { Protection }\end{array}$ & $\begin{array}{l}\text { Municipal Protection } \\
\text { Measure }\end{array}$ & Implementation \\
\hline
\end{tabular}

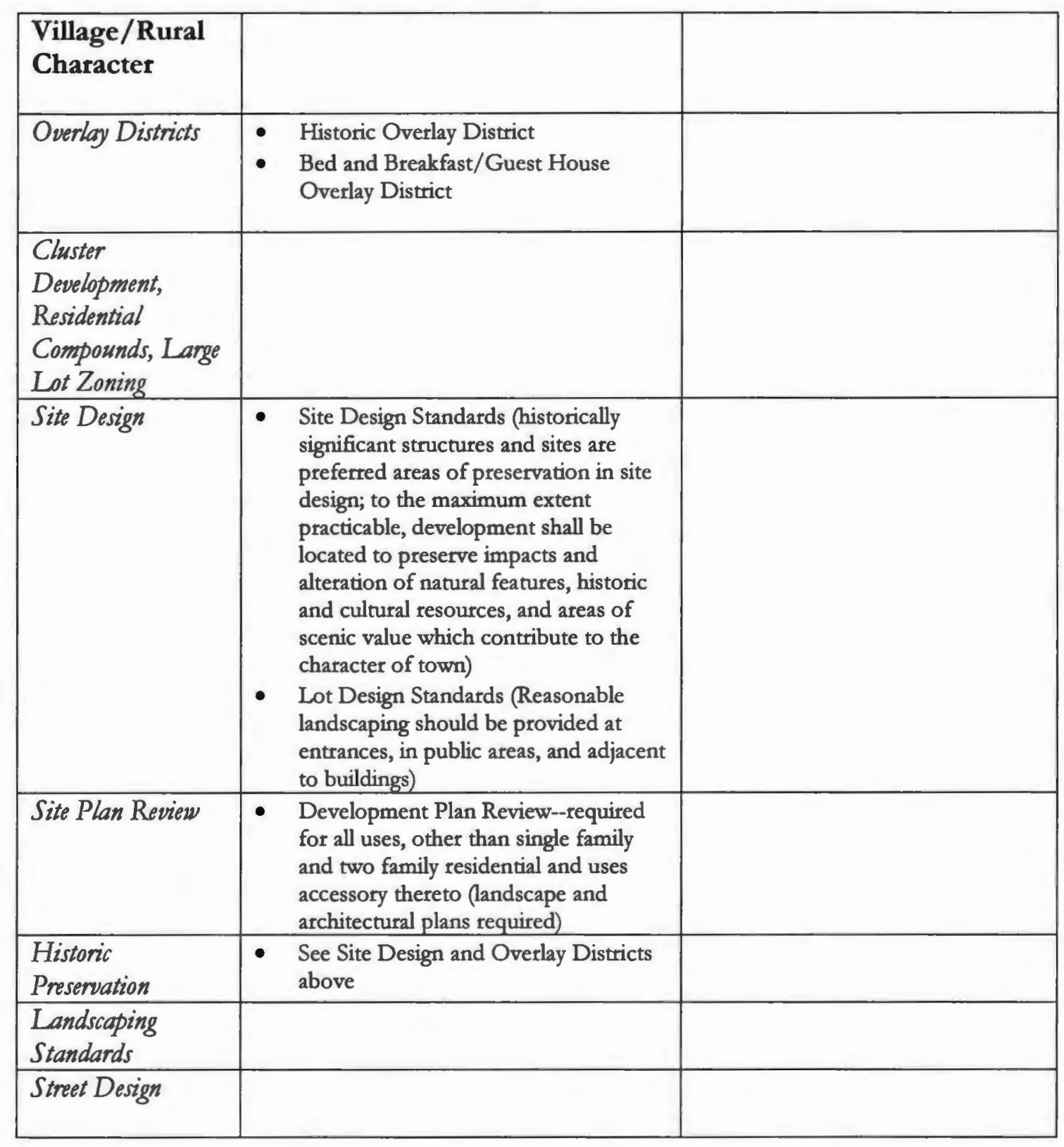


REGUI_ATORY COMPARISON BY NA'IURAI RESOURCE AREA AND PROTECITON MEASURF

\begin{tabular}{|c|c|c|c|c|}
\hline $\begin{array}{c}\text { Natural Resource } \\
\text { Protection }\end{array}$ & Charlestown & Coventry & Exeter & Hopkinton \\
\hline $\begin{array}{l}\text { Land } \\
\text { Conservation }\end{array}$ & & & & \\
\hline $\begin{array}{l}\text { Farmland } \\
\text { Preservation }\end{array}$ & & & & \\
\hline Zoning Regulations & $\begin{array}{l}\text { - Agricultural land may serve as open } \\
\text { space in cluster developments zo } \\
\text { - Protection of farmland is mentioned } \\
\text { as a public purpose of the Planned } \\
\text { Development District zo }\end{array}$ & $\begin{array}{l}\text { Residential Cluster Development, } \\
\text { Criteria for Approval (open space shall, } \\
\text { where applicable, encourage } \\
\text { agricultural and forest management } \\
\text { activities...Areas in which prime } \\
\text { agricultural soils are located shall be } \\
\text { preserved to the greatest extent } \\
\text { possible)zo } \\
\text { Residential Cluster Development, } \\
\text { Common Open Space Requirements } \\
\text { (If the parcel is located in an } \\
\text { agricultural district, farmland owners } \\
\text { are not required to convey the part of } \\
\text { their property which is to become } \\
\text { permanent open space, provided that } \\
\text { they convey the development rights of } \\
\text { that open space) zo } \\
\text { Special Requirements, Residential } \\
\text { Cluster Development (any parcel of } \\
\text { land containing Prime Farmland of } \\
\text { Farmland of Statewide Importance, } \\
\text { and has been under cultivation at any } \\
\text { time during the five years immediately } \\
\text { preceding the date of subdivision } \\
\text { application, shall be designed as a } \\
\text { residential cluster development or a } \\
\text { residential compound in such a way as } \\
\text { to preserve at least } 50 \% \text { of the } \\
\text { farmland for agricultural uses, provided } \\
\text { that the characteristics of the parcel are } \\
\text { such that the farmland is capable of } \\
\text { being arranged in a lot of at least } 5 \\
\text { contiguous acres; a } 20 \% \text { density bonus } \\
\text { may be granted for preservation of } \\
\text { prime and important farmland on such } \\
\text { parcels) }\end{array}$ & $\begin{array}{l}\text { - RU-3 and RU-4 (Rural Districts)--The } \\
\text { stated purpose of the RU-4 district is } \\
\text { to protect land now used for forestry, } \\
\text { farming, and related activities and the } \\
\text { natural habitat and wildlife and to } \\
\text { preserve the area's rural character. zo } \\
\text { Raising of animals is allowed either by } \\
\text { right or by special use permit in all } \\
\text { zones except Business (B) zo } \\
\text { Farming and forestry are allowed by } \\
\text { right or special use permit in all zones } \\
\text { except Light Industrial (LI) zo }\end{array}$ & $\begin{array}{l}\text { - Rural Farming Residential-80 } \\
\text { District zo }\end{array}$ \\
\hline
\end{tabular}




\begin{tabular}{|c|c|c|c|c|}
\hline \multicolumn{5}{|l|}{$\begin{array}{l}\text { Farmland } \\
\text { Preservation }\end{array}$} \\
\hline Site Design & & $\begin{array}{l}\text { Site Design (preferred preservation of } \\
\text { "Agricultural Lands" as undeveloped } \\
\text { open space or lot area; site analysis } \\
\text { required for all major subdivisions and } \\
\text { minor subdivisions by request of the } \\
\text { Planning Commission) }\end{array}$ & & $\begin{array}{l}\text { Site Design Standards (for major } \\
\text { subdivisions, agricultural lands shall } \\
\text { be preserved as undeveloped open } \\
\text { space or lot area where feasible) }\end{array}$ \\
\hline $\begin{array}{l}\text { Open Space } \\
\text { Zoning }\end{array}$ & $\begin{array}{l}\text { Permitted uses "by right" include: } \\
\text { most recreational uses, government } \\
\text { administrative buildings, libraries and } \\
\text { minor recreation centers, as well as } \\
\text { commercial uses such as driving } \\
\text { ranges and riding stables. zo } \\
\text { Agricultural uses are allowed subject } \\
\text { to performance standards. zo }\end{array}$ & $\begin{array}{l}\text { No } \\
\text { - Open Lands" classified as } \\
\text { conservation lands, wildlife areas, and } \\
\text { nature preserves are allowed by right in } \\
\text { all zoning districts. Open lands } \\
\text { operated as commercial picnic groves } \\
\text { are allowed by special permit in RR5 } \\
\text { and RR2 districts and prohibited in all } \\
\text { other districts }\end{array}$ & $\begin{array}{l}\text { Residential Singte-Family, raising of } \\
\text { animals, farming, and roadside stands, } \\
\text { municipal buildings are allowed by } \\
\text { special use permit zo }\end{array}$ & - No \\
\hline \multicolumn{5}{|l|}{$\begin{array}{l}\text { Open Space } \\
\text { Preservation }\end{array}$} \\
\hline $\begin{array}{l}\text { Cluster Development, } \\
\text { Residential Compounds, } \\
\text { Lange Lot Zoning }\end{array}$ & $\begin{array}{l}\text { Mandatory cluster for all major } \\
\text { subdivisions in R-3A, R-2A and R-40 } \\
\text { Zoning Districts (40\% of the total } \\
\text { land area must be protected open } \\
\text { space, } 35 \% \text { of which must be suitable } \\
\text { for active recreational purposes; no } \\
\text { more than } 25 \% \text { shall be made } \\
\text { impervious; unbuildable land may } \\
\text { account for a maximum of } 50 \% \text { of } \\
\text { protected open space) zo } \\
\text { Residential Compounds allowed in } \\
\text { the R-3A and R-2A zones zo }\end{array}$ & $\begin{array}{l}\text { Residential Cluster Development } \\
\text { permitted in RR-5, RR-2 and R-20 } \\
\text { Zoning Districts (density bonuses up } \\
\text { to } 20 \% \text { may be permitted if a } \\
\text { minimum set aside of } 50 \% \text { percent of } \\
\text { the land is open space) zo; } \\
\text { Special Requirements, Residential } \\
\text { Cluster Development (40\% of the } \\
\text { gross area of the RCD must be open } \\
\text { space; no more than } 50 \% \text { of the } \\
\text { minimum open space shall be land } \\
\text { unsuitable for development; land } \\
\text { which has been environmentally } \\
\text { damaged prior to final approval of the } \\
\text { development) } \\
\text { Special Requirements, Residential } \\
\text { Compounds (in RR-2 zone, one } \\
\text { dwelling unit per } 5 \text { acres of land } \\
\text { suitable for development, in RR-5 } \\
\text { zone, one dwelling per } 10 \text { acres) }\end{array}$ & $\begin{array}{l}\text { RU-3 and RU-4, Rural Residential } \\
\text { Zoning Districts; } 5 \text { acre } \\
\text { Conservation/Recreation District zo }\end{array}$ & $\begin{array}{l}\text { Residential Cluster Development } \\
\text { only allowed in RFR- } 80 \text { District } \\
\text { (minimum parcel size is } 10 \text { acres, ( } \\
30 \% \text { of the total area of the district } \\
\text { must be permanent open space, } \\
\text { excluding roads, wetlands, ponds, } \\
\text { marshes, natural areas, areas } \\
\text { classified as unique, slopes greater } \\
\text { than } 15 \% \text { ) zo }\end{array}$ \\
\hline
\end{tabular}


REGULATORY COMPARISON BY NATURAL RESOURCE AREA AND PRO'TECTION MEASURE

\section{Natural Resource}

Protection

Charlestown

Coventry

Exeter

Hopkinton

\begin{tabular}{|c|c|c|c|c|}
\hline $\begin{array}{l}\text { Open Space } \\
\text { Preservation } \\
\text { (continued) }\end{array}$ & & & & \\
\hline $\begin{array}{l}\text { Land Unsuitable for } \\
\text { Development }\end{array}$ & $\begin{array}{l}\text { Land Unsuitable for Development } \\
\text { (shall be deducted from the } \\
\text { developable acreage of the parcel-- } \\
\text { resource areas subject to protective } \\
\text { setback distance such as but not } \\
\text { limited to, wetlands; areas subject to } \\
\text { storm flow or flooding; hydric soils } \\
\text { and inter-tidal salt marshes; land } \\
\text { located in any V zones or floodways; } \\
\text { any area of the track proposed to be } \\
\text { developed equal to the area of any } \\
\text { street and/or utility rights-of-way; any } \\
\text { unique sites having historical, } \\
\text { archeological values or protected } \\
\text { species of flora or fauna; any other } \\
\text { lands which if developed would cause } \\
\text { a threat to public health, or result in } \\
\text { irreparable public harm, or loss of } \\
\text { irreplaceable resources; any area of } \\
\text { ledge and/or rock outcrops at/or } \\
\text { within four feet of the land surface, } \\
\text { any area where slopes exceed fifteen } \\
\text { percent) }\end{array}$ & $\begin{array}{l}\text { Land Unsuitable for Development } \\
\text { (shall be subtracted from the total } \\
\text { parcel in order to determine the } \\
\text { maximum number of dwelling units-- } \\
\text { wetlands, including perimeter wetlands; } \\
\text { land located within Zone A on a } \\
\text { FEMA Map; street allowance; all } \\
\text { existing public and private easements; } \\
\text { land containing steep slopes in excess } \\
\text { of } 20 \% \text { within any } 10 \text { feet interval on } \\
\text { the contour drawing) }\end{array}$ & & $\begin{array}{l}\text { Land Unsuitable for Development } \\
\text { (shall be deducted from the } \\
\text { minimum building acreage of the } \\
\text { parcel--freshwater wetlands, areas } \\
\text { within a High Flood Danger zone, } \\
\text { and land within any publicly or } \\
\text { privately held easement on which } \\
\text { above-ground utilities, including but } \\
\text { not limited to electrical transmission } \\
\text { lines, are constructed; land with } \\
\text { slopes in excess of } 15 \text { percent) }\end{array}$ \\
\hline $\begin{array}{l}\text { Dedication of Land for } \\
\text { Public Purposes }\end{array}$ & $\begin{array}{l}\text { Recreation Facilities and Open Space } \\
\text { Dedication (land dedication, payment } \\
\text { in lieu or both are required; amount } \\
\text { of land to be dedicated is } \\
.01 \text { acres/person) }\end{array}$ & $\begin{array}{l}\text { Dedication of Land for Public } \\
\text { Purposes (land dedication, payment in } \\
\text { lieu or both are required; amount of } \\
\text { land to dedicated is } 01 \text { acres per } \\
\text { person) }\end{array}$ & $\begin{array}{l}\text { Dedication of Land for Public } \\
\text { Purposes (minimum amount is } 3 \% \text { of } \\
\text { total gross acres of development } \\
\text { parcel) }\end{array}$ & $\begin{array}{l}\text { Dedication of Land for Public } \\
\text { Purposes (may be required; amount } \\
\text { of land to be dedicated is . } 01 \text { per } \\
\text { person) }\end{array}$ \\
\hline
\end{tabular}


REGULATORY COMPARISON BY NA'IURAL, RESOURCE AREA AND PROTECTION MEASURE

\section{Natural Resource}

Protection

Charlestown

Coventry

Exeter

Hopkinton

\begin{tabular}{|c|c|c|}
\hline $\begin{array}{l}\text { Open Space } \\
\text { Preservation } \\
\text { (continued) }\end{array}$ & & \\
\hline Site Design & $\begin{array}{l}\text { - Site Design (The following areas shall } \\
\text { be preserved as undeveloped open } \\
\text { space or lot area, to the extent } \\
\text { consistent with the reasonable } \\
\text { utilization of land-unique and/or } \\
\text { fragile areas, including freshwater } \\
\text { wetlands; significant trees or stands of } \\
\text { trees, or other vegetative species that } \\
\text { are rare to the area or are of particular } \\
\text { horticultural or landscape value; land in } \\
\text { the flood plain; steep slopes in excess } \\
\text { of } 20 \% \text { unless appropriate engineering } \\
\text { measures are taken into consideration; } \\
\text { habitat of endangered wildlife; } \\
\text { historically significant structures and } \\
\text { sites; agricultural lands) }\end{array}$ & $\begin{array}{l}\text { - Site Design (The following areas } \\
\text { shall be preserved as undeveloped } \\
\text { open space or lot area, to the extent } \\
\text { consistent with the reasonable } \\
\text { urilization of land-unique and/or } \\
\text { fragile areas, including freshwater } \\
\text { wetlands; significant trees or stands } \\
\text { of trees, or other vegetative species } \\
\text { that are rare to the area or are of } \\
\text { particular horticultural or landscape } \\
\text { value; lands in the flood plain; steep } \\
\text { slopes in excess of } 15 \% \text { unless } \\
\text { appropriate engineering measures } \\
\text { are taken into consideration; habitat } \\
\text { of endangered wildlife; historically } \\
\text { significant structures and sites; } \\
\text { agricultural lands) }\end{array}$ \\
\hline Site Plan Review & $\begin{array}{l}\text { Development Plan Review, Criteria } \\
\text { (required for any residential project not } \\
\text { requiring subdivision approval that } \\
\text { exceeds } 6 \text { dwellings, construction or } \\
\text { expansion of all non-residential sites, } \\
\text { applications requiring a special use } \\
\text { permit, zoning map change or } \\
\text { variance---Building sites shall, to the } \\
\text { extent feasible: maximize open space } \\
\text { retention...) }\end{array}$ & \\
\hline
\end{tabular}


REGULATORY COMPARISON BY NA'IURAL RFSOURCE AREA AND PRO'TECTION MEASURE

\section{Natural Resource}

Protection

\section{Charlestown}

Coventry

Exeter

Hopkinton

\begin{tabular}{|c|c|c|c|c|}
\hline $\begin{array}{l}\text { Natural Resource } \\
\text { Protection }\end{array}$ & & & & \\
\hline \multicolumn{5}{|l|}{ Wetlands } \\
\hline $\begin{array}{l}\text { Erosion and Sediment } \\
\text { Control Plan }\end{array}$ & $\begin{array}{l}\text { Erosion and Sediment Control Plan } \\
\text { (required for all major subdivisions } \\
\text { and land developments as well as any } \\
\text { development within } 200 \text { feet of any } \\
\text { waterbody, watercourse, wetland or } \\
\text { coastal feature) }\end{array}$ & $\begin{array}{l}\text { Erosion and Sediment Control Plan } \\
\text { (required for all land developments and } \\
\text { subdivisions prior to any clearing of } \\
\text { land) }\end{array}$ & $\begin{array}{l}\text { Erosion and Sediment Control Plan } \\
\text { (required for all development) }\end{array}$ & $\begin{array}{l}\text { Erosion and Sediment Control Plan } \\
\text { (required for all major subdivisions } \\
\text { and land developments as well as } \\
\text { minor and administrative } \\
\text { subdivisions if deemed necessary by } \\
\text { planning board) }\end{array}$ \\
\hline $\begin{array}{l}\text { Land Unsuitable for } \\
\text { Development }\end{array}$ & $\begin{array}{l}\text { - Wetlands are defined as "land } \\
\text { unsuitable for development" }\end{array}$ & $\begin{array}{l}\text { Wetlands are considered "land } \\
\text { unsuitable for development" }\end{array}$ & & $\begin{array}{l}\text { Freshwater wetlands are considered } \\
\text { "land unsuitable for development" }\end{array}$ \\
\hline $\begin{array}{l}\text { Environmental } \\
\text { Analysis/Impact } \\
\text { Statement }\end{array}$ & $\begin{array}{l}\text { Environmental Analysis (for all major } \\
\text { applications as well as land } \\
\text { development occurring on sites with } \\
\text { wetlands or high watertables) }\end{array}$ & $\begin{array}{l}\text { Environmental Review Team Report } \\
\text { (if all or part of the property is } \\
\text { identified in the Natural and Cultural } \\
\text { Resources Element of the } \\
\text { Comprehensive Plan; the Planning } \\
\text { Commission finds that there is } \\
\text { reasonable expectation of negative } \\
\text { environmental impact...) }\end{array}$ & $\begin{array}{l}\text { General Requirements, Project } \\
\text { description and impact statement } \\
\text { (Narrative description and impact } \\
\text { report required for all major } \\
\text { subdivisions and land developments; } \\
\text { an EIS may be required for any } \\
\text { development at the request of the } \\
\text { Planning Board) }\end{array}$ & $\begin{array}{l}\text { Impact Statement (may be required } \\
\text { if there is reasonable expectation of } \\
\text { a significant negative environmental } \\
\text { impact on natural systems) }\end{array}$ \\
\hline Site Design & $\begin{array}{l}\text { Physical Design and Public } \\
\text { Improvement Standards (existing } \\
\text { features such as woodlands, wetlands, } \\
\text { cemeteries, wildflower sites, } \\
\text { archeological sites, areas of unique } \\
\text { botanical interest and similar } \\
\text { irreplaceable assets, shall be preserved } \\
\text { in the design of the subdivision) }\end{array}$ & $\begin{array}{l}\text { - Site Design (prefcrred preservation of } \\
\text { freshwater wetlands as undeveloped } \\
\text { open space or lot area; site analysis } \\
\text { required for all major subdivisions and } \\
\text { minor subdivisions by request of the } \\
\text { Planning Commission) } \\
\text { - Site Design, Site Analysis (required for } \\
\text { all major subdivisions and minor } \\
\text { subdivisions by request of the Planning } \\
\text { Commission, developer must include } \\
\text { written and/or graphic analysis of } \\
\text { wetlands and an assessment describing } \\
\text { potential effects of the proposed } \\
\text { development) }\end{array}$ & $\begin{array}{l}\text { Design Standards (freshwater wetlands } \\
\text { cannot be excavated, drained, filled nor } \\
\text { shall any extraneous materials be } \\
\text { placed into these wetlands) }\end{array}$ & $\begin{array}{l}\text { Lot Design Standards (easement } \\
\text { may be require if property is } \\
\text { traversed by a water course, drainage } \\
\text { way, channel or stream, there shall } \\
\text { be provided a stormwater easement } \\
\text { or drainage right-of-way) } \\
\text { - Site Design Standards (Unique } \\
\text { and/or fragile areas, including } \\
\text { freshwater wetlands shall be } \\
\text { preserved as undeveloped open } \\
\text { space or lot areas where feasible) }\end{array}$ \\
\hline
\end{tabular}




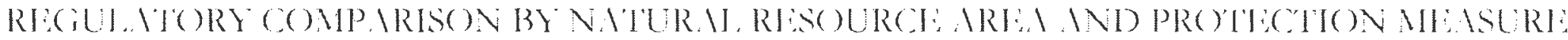

Natural Resource

Protection

Charlestown

Coventry

Exeter

Hopkinton

\begin{tabular}{|c|c|c|c|c|}
\hline $\begin{array}{l}\text { Wetlands } \\
\text { (continued) }\end{array}$ & & & & \\
\hline Site Plan Review & $\begin{array}{l}\text { - Site Plan Review, Standards (sites to } \\
\text { be developed shall alter the natural } \\
\text { topography as minimally as possible } \\
\text { and shall avoid 'Constraints to } \\
\text { Devclopment') }\end{array}$ & $\begin{array}{l}\text { Devclopment Plan Revicw, Critcria } \\
\text { (Building sites shall, to the cxtent } \\
\text { fcasible: minimizc usc of wetlands...) }\end{array}$ & $\begin{array}{l}\text { Development Plan Review, Water } \\
\text { bodies, (Whenever situated in the } \\
\text { whole or in part, within } 300 \text { feet of any } \\
\text { pond, lake, river or other freshwater } \\
\text { wetland, the proposed project shall not } \\
\text { adversely effect the quality of such } \\
\text { body of water or unreasonably affect } \\
\text { the shoreline of such body of water. } \\
\text { There will be no disturbance of soil } \\
\text { within } 100 \text { feet of the outer edge of a } \\
\text { wetland (as defined by DEM)) zo }\end{array}$ & $\begin{array}{l}\text { Development Plan Rcview, } \\
\text { Ecological Considerations (The } \\
\text { development insofar as practicable } \\
\text { shall: result in minimal degradation } \\
\text { of unique or irreplaceable land types } \\
\text { and in minimum adverse impact } \\
\text { upon the critical areas such as } \\
\text { streams, wetlands...) zo }\end{array}$ \\
\hline Performance Standards & $\begin{array}{l}\text { Performance Standards, Water bodies } \\
\text { (No facility designed to leach liquid } \\
\text { wastes into the soil shall be located } \\
\text { within } 100 \text { feet of a boundary of a } \\
\text { freshwater or coastal wetland) zo }\end{array}$ & $\begin{array}{l}\text { Performance Standards, Hazardous } \\
\text { Waste Management Facilities, Siting } \\
\text { Restrictions (shall be prohibited in } \\
\text { environmentally sensitive areas) zo }\end{array}$ & & \\
\hline Other & & $\begin{array}{l}\text { General Devclopment Regulations, } \\
\text { Watcr Bodics (No disposal trench or } \\
\text { bed, cesspool, scepage pit or other } \\
\text { facility shall be located: within } 75 \text { fect } \\
\text { of a fresh water wetland, stream, river, } \\
\text { pond or lake...) zo }\end{array}$ & & \\
\hline
\end{tabular}


REGULA'TORY COMPARISON BY NA'TURAL RESOURCE AREA AND PRO'TECT'TON MFASURE

\section{Natural Resource}

Protection

\section{Charlestown}

Coventry

Exeter

Hopkinton

\begin{tabular}{|c|c|c|c|c|}
\hline $\begin{array}{l}\text { Watercourses/ } \\
\text { Surface Waters }\end{array}$ & & & & \\
\hline $\begin{array}{l}\text { Erosion and Sediment } \\
\text { Control Plan }\end{array}$ & $\begin{array}{l}\text { Erosion and Sediment Control Plan } \\
\text { (for all major applications as well as } \\
\text { all development within } 200 \text { feet of } \\
\text { any waterbody, watercourse, wetland } \\
\text { or coastal feature) }\end{array}$ & $\begin{array}{l}\text { Erosion and Sediment Control Plan } \\
\text { (required for all land developments and } \\
\text { subdivisions prior to any clearing of } \\
\text { land) }\end{array}$ & $\begin{array}{l}\text { Erosion and Sediment Control } \\
\text { Performance Principles (Development } \\
\text { plans shall preserve salient natural } \\
\text { features, keep cut and fill operacions to } \\
\text { a minimum and ensure conformity } \\
\text { with topography so as to adequately } \\
\text { handle the volume and velocity of } \\
\text { surface water runoff, and create the } \\
\text { least erosion potential) }\end{array}$ & $\begin{array}{l}\text { Erosion and Sediment Control Plan } \\
\text { (required for all major subdivisions } \\
\text { and land developments as well as } \\
\text { minor and administrative } \\
\text { subdivisions if deemed necessary by } \\
\text { planning board) }\end{array}$ \\
\hline Protection District & $\begin{array}{l}\text { Flood Hazard Areas (Development } \\
\text { that alters water-carrying capacity is } \\
\text { prohibited pursuant to the flood } \\
\text { hazard overlay district) zo }\end{array}$ & & & $\begin{array}{l}\text { - Floodplain and Watercourse } \\
\text { Protection District zo }\end{array}$ \\
\hline $\begin{array}{l}\text { Environmental } \\
\text { Analysis/Impact } \\
\text { Statement }\end{array}$ & $\begin{array}{l}\text { Environmental Analysis (required } \\
\text { where Planning Commission finds a } \\
\text { reasonable cause that the proposed } \\
\text { development will have a negative } \\
\text { environmental impact on the natural } \\
\text { or manmade environment on the } \\
\text { property or upon nearby properties or } \\
\text { natural systems) }\end{array}$ & $\begin{array}{l}\text { Environmental Review Team Report } \\
\text { (if all or part of the property is } \\
\text { identified in the Natural and Cultural } \\
\text { Resources Element of the } \\
\text { Comprehensive Plan; the Planning } \\
\text { Commission finds that there is } \\
\text { reasonable expectation...of negative } \\
\text { environmental impact...) }\end{array}$ & $\begin{array}{l}\text { General Requirements, Project } \\
\text { description and impact statement } \\
\text { (Narrative description and impact } \\
\text { report required for all major } \\
\text { subdivisions and land developments; } \\
\text { an EIS may be required for any } \\
\text { development at the request of the } \\
\text { Planning Board) }\end{array}$ & $\begin{array}{l}\text { - Impact Statement ( may be required } \\
\text { if there is reasonable expectation of } \\
\text { a significant negative environmental } \\
\text { impact on natural systems) }\end{array}$ \\
\hline Setbackes & & $\begin{array}{l}\text { General Development Regulations, } \\
\text { Water Bodies (No disposal trench or } \\
\text { bed, cesspool, seepage pit or other } \\
\text { facility shall be located: within } 75 \text { feet } \\
\text { of a fresh water wetland, stream, river, } \\
\text { pond or lake... }\end{array}$ & & \\
\hline
\end{tabular}


REGULA'TORY COMPARISON BY NATURAL, RFSOURCE AREA AND PRO'TECTION MEASURE

\begin{tabular}{|c|c|c|c|c|}
\hline $\begin{array}{l}\text { Watercourses/ } \\
\text { Surface Waters } \\
\text { (continued) }\end{array}$ & & & & \\
\hline Site Design & & $\begin{array}{l}\text { Lot Design Standards (where a } \\
\text { subdivision is traversed by a water } \\
\text { course, drainage way, channel or } \\
\text { stream, there shall be provided a } \\
\text { stormwater easement right-of-way } \\
\text { conforming substantially with the lines } \\
\text { of such water course and of such width } \\
\text { as will be adequate for the purpose) } \\
\text { Site Design, Site Analysis (required for } \\
\text { all major subdivisions and minor } \\
\text { subdivisions by request of the Planning } \\
\text { Commission, developer must include } \\
\text { written and/or graphic analysis of } \\
\text { wetlands and an assessment describing } \\
\text { potential effects of the proposed } \\
\text { development) }\end{array}$ & & $\begin{array}{l}\text { Lot Design Standards (easement } \\
\text { may be require if property is } \\
\text { traversed by a water course, drainage } \\
\text { way, channel or stream, there shall } \\
\text { be provided a stormwater easement } \\
\text { or drainage right-of-way) }\end{array}$ \\
\hline Site Plan Review & $\begin{array}{l}\text { Site Plan Review, Standards } \\
\text { (measures shall conform to the } \\
\text { minimum standards of the } 1993 \text { State } \\
\text { of R Stormwater Manual) zo }\end{array}$ & $\begin{array}{l}\text { Development Plan Review, Criteria } \\
\text { (the development plan shall show } \\
\text { adequate measures to prevent pollution } \\
\text { of surface or groundwater, to minimize } \\
\text { erosion and sedimentation, and to } \\
\text { prevent changes in groundwater levels, } \\
\text { increased runoff and potential for } \\
\text { flooding...) zo } \\
\text { Development Plan Review, Criteria } \\
\text { (Building sites shall, to the extent } \\
\text { feasible: prevent depletion or } \\
\text { degradation of public drinking water } \\
\text { supplies by employing best } \\
\text { management practices for erosion } \\
\text { control, storm water management, } \\
\text { wastewater disposal and landscaping) }\end{array}$ & $\begin{array}{l}\text { Development Plan Review, Water } \\
\text { bodies, (Whenever situated in the } \\
\text { whole or in part, within } 300 \text { feet of any } \\
\text { pond, lake, river or other freshwater } \\
\text { wetland, the proposed project shall not } \\
\text { adversely effect the quality of such } \\
\text { body of water or unreasonably affect } \\
\text { the shoreline of such body of water. } \\
\text { There will be no disturbance of soil } \\
\text { within } 100 \text { feet of the outer edge of a } \\
\text { wetland (as defined by DEM)) zo }\end{array}$ & $\begin{array}{l}\text { Development Plan Review, } \\
\text { Ecological Considerations (The } \\
\text { development insofar as practicable } \\
\text { shall: result in minimal degradation } \\
\text { of unique or irreplaceable land types } \\
\text { and in minimum adverse impact } \\
\text { upon the critical areas such as } \\
\text { streams, wetlands...) zo }\end{array}$ \\
\hline
\end{tabular}


REGULATORY COMPARISON BY NATURAL RESOURCE AREA AND PRO'IECTION MEASURF. Natural Resource

Protection

\section{Charlestown}

Coventry

Exeter

Hopkinton

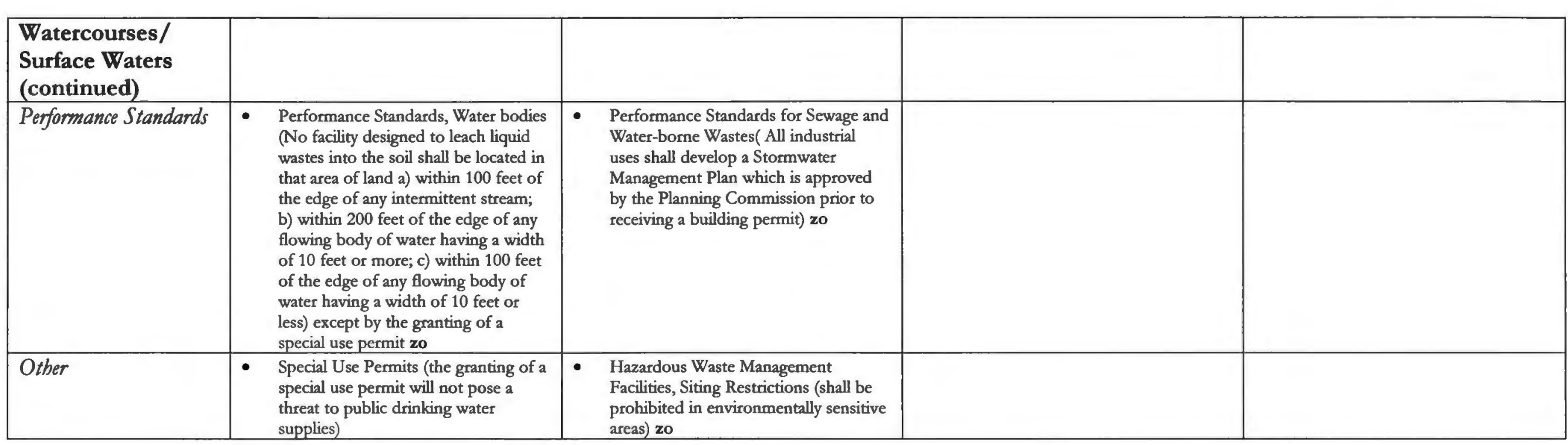


REGUI ATIORY COMPARISON BY NA'TURAL RFSOURCE AREA AND PRO'TECTTON MEASURF

\section{Natural Resource}

Protection

\section{Charlestown}

Coventry

Exeter

Hopkinton

\begin{tabular}{|c|c|c|c|c|}
\hline $\begin{array}{l}\text { Groundwater/ } \\
\text { Recharge Areas }\end{array}$ & & & & \\
\hline Protection District & $\begin{array}{l}\text { - Groundwater Protection Overlay } \\
\text { District (site plan review and an } \\
\text { environmental impact statement are } \\
\text { required) zo }\end{array}$ & & $\begin{array}{l}\text { - Groundwater Protection Overlay } \\
\text { District zo }\end{array}$ & \\
\hline $\begin{array}{l}\text { Environmental } \\
\text { Analysis/Impact } \\
\text { Statement }\end{array}$ & $\begin{array}{l}\text { Environmental Analysis (required for } \\
\text { all development in areas designated } \\
\text { by RIDEM as a groundwater } \\
\text { reservoir, groundwater recharge area, } \\
\text { or wellhead protection area) }\end{array}$ & $\begin{array}{l}\text { - Hazardous Waste Management } \\
\text { Facilities, Siting Restrictions (shall be } \\
\text { prohibited in environmentally sensitive } \\
\text { areas) } \\
\text { Environmental Review Team Report } \\
\text { (The Planning Commission. may } \\
\text { require the applicant to pay for an ERT } \\
\text { prepared by the RI Resource } \\
\text { Conservation and Development } \\
\text { Council, Inc.--if all or part of the } \\
\text { property is identified in the Natural } \\
\text { and Cultural Resources Element of the } \\
\text { Comprehensive Plan; the Planning } \\
\text { Commission finds that there is } \\
\text { reasonable expectation...of negative } \\
\text { environmental impact...) }\end{array}$ & $\begin{array}{l}\text { General Requirements, Project } \\
\text { description and impact statement } \\
\text { (Narrative description and impact } \\
\text { report required for all major } \\
\text { subdivisions and land developments; } \\
\text { an EIS may be required for any } \\
\text { development at the request of the } \\
\text { Planning Board) }\end{array}$ & $\begin{array}{l}\text { - Impact Statement (may be required } \\
\text { if there is reasonable expectation of } \\
\text { a significant negative environmental } \\
\text { impact on natural systems) }\end{array}$ \\
\hline Site Design & $\begin{array}{l}\text { Site Design Standards (development } \\
\text { shall be laid out to avoid adversely } \\
\text { affecting groundwater and aquifer } \\
\text { recharge...) }\end{array}$ & $\begin{array}{l}\text { - Site Design Standards (development } \\
\text { shall be laid out to avoid adversely } \\
\text { affecting ground water and aquifer } \\
\text { recharge; to reduce cut and fill; to } \\
\text { avoid unnecessary impervious cover } \\
\text { and to prevent flooding...) }\end{array}$ & & $\begin{array}{l}\text { - Site Design standards (development } \\
\text { shall be laid out to avoid adversely } \\
\text { affecting ground water and aquifer } \\
\text { recharge; to reduce cut and fill; to } \\
\text { avoid unnecessary impervious cover; } \\
\text { to prevent flooding) }\end{array}$ \\
\hline Site Plan Review & $\begin{array}{l}\text { Site Plan Review, Standards, } \\
\text { Environmental Constraints (sites to } \\
\text { be developed shall avoid areas of high } \\
\text { groundwater, seasonal or permanent) } \\
\text { zo }\end{array}$ & $\begin{array}{l}\text { Development Plan Review, Criteria } \\
\text { (the development plan shall show } \\
\text { adequate measures to prevent pollution } \\
\text { of surface or groundwater, to minimize } \\
\text { erosion and sedimentation, and to } \\
\text { prevent changes in groundwater levels, } \\
\text { increased runoff and potential for } \\
\text { flooding...) zo }\end{array}$ & $\begin{array}{l}\text { Development Plan Review (The } \\
\text { project shall be designed to prevent the } \\
\text { pollution of surface or ground water } \\
\text { resources; the planning board may } \\
\text { require specific site designs, best } \\
\text { management practices, and/or } \\
\text { applicable management measures to } \\
\text { protect surface and ground water } \\
\text { quality) zo }\end{array}$ & $\begin{array}{l}\text { Development Plan Review, } \\
\text { Ecological Considerations (The } \\
\text { development insofar as practicable } \\
\text { shall result in minimal degradation } \\
\text { of unique or irreplaceable land types } \\
\text { and in minimum adverse impact } \\
\text { upon the critical areas such as } \\
\text { streams, wetlands, areas of aquifer } \\
\text { recharge and discharge....areas with } \\
\text { a high water table...) zo } \\
\end{array}$ \\
\hline Other & & & & \\
\hline
\end{tabular}


REGULATORY COMPARISON BY NA'TURAI, RESOURCE AREA AND PRO'TECTION MFASURF

\section{Natural Resource}

Protection

\section{Charlestown}

Coventry

Exeter

Hopkinton

\begin{tabular}{|c|c|c|c|c|}
\hline Floodplains & & & & \\
\hline Protection District & $\begin{array}{l}\text { Flood Hazard Areas (Development } \\
\text { that alters water-carrying capacity is } \\
\text { prohibited pursuant to the flood } \\
\text { hazard overlay district) zo }\end{array}$ & & & $\begin{array}{ll}\text { - Floodplain and Watercourse } \\
\text { Protection District zo }\end{array}$ \\
\hline $\begin{array}{l}\text { Land Unsuitable for } \\
\text { Development }\end{array}$ & $\begin{array}{l}\text { Areas subject to storm flow or } \\
\text { looding defined as "land unsuitable } \\
\text { for development" }\end{array}$ & $\begin{array}{l}\text { - Land located within Zone A on a } \\
\text { FEMA Map is considered "land } \\
\text { unsuitable for development" }\end{array}$ & & $\begin{array}{l}\text { - Areas within a High Flood Danger } \\
\text { Zone are considered "land } \\
\text { unsuitable for development" }\end{array}$ \\
\hline $\begin{array}{l}\text { Environmental } \\
\text { Analysis/Impact } \\
\text { Statement }\end{array}$ & $\begin{array}{l}\text { Environmental Analysis (required for } \\
\text { all developments partially or wholly } \\
\text { located in an area designated as a } \\
\text { floodway, } \mathrm{V} \text { zone or } 100 \text { year } \\
\text { floodplain) }\end{array}$ & $\begin{array}{l}\text { ERT (Environmental Review Team } \\
\text { Report) may be required by Planning } \\
\text { Commission. }\end{array}$ & $\begin{array}{l}\text { General Requirements, Project } \\
\text { description and impact statement } \\
\text { (Narrative description and impact } \\
\text { report required for all major } \\
\text { subdivisions and land developments; } \\
\text { an EIS may be required for any } \\
\text { development at the request of the } \\
\text { Planning Board) }\end{array}$ & $\begin{array}{l}\text { Impact Statement (may be required } \\
\text { if there is reasonable expectation of } \\
\text { a significant negative environmental } \\
\text { impact on natural systems) }\end{array}$ \\
\hline Site Design & & $\begin{array}{l}\text { Site Design (preferred preservation of } \\
\text { lands in the floodplain as undeveloped } \\
\text { open space or lot area; site analysis } \\
\text { require for all major subdivisions and } \\
\text { minor subdivisions by request of the } \\
\text { Planning Commission) } \\
\text { - Site Design Standards (development } \\
\text { shall be laid out to reduce cut and fill; } \\
\text { to avoid unnecessary impervious cover; } \\
\text { to prevent flooding...) }\end{array}$ & & $\begin{array}{l}\text { Site Design standards (lands in the } \\
\text { flood plain shall be preserved as } \\
\text { undeveloped open space where } \\
\text { feasible) } \\
\text { Lot Design Standards (easement } \\
\text { may be require if property is } \\
\text { traversed by a water course, drainage } \\
\text { way, channel or stream, there shall } \\
\text { be provided a stormwater easement } \\
\text { or drainage right-of-way) }\end{array}$ \\
\hline
\end{tabular}




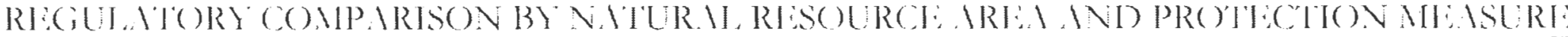

\begin{tabular}{|c|c|c|c|c|}
\hline $\begin{array}{c}\text { Natural Resource } \\
\text { Protection }\end{array}$ & Charlestown & Coventry & Exeter & Hopkinton \\
\hline $\begin{array}{l}\text { Floodplains } \\
\text { (continued) }\end{array}$ & & & & \\
\hline Site Plan Review & $\begin{array}{l}\text { Site Plan Revicw, Standards (sites } \\
\text { to be developed shall alter the } \\
\text { natural topography as minimally } \\
\text { as possible and shall avoid } \\
\text { 'Constraints to Development') }\end{array}$ & $\begin{array}{l}\text { Development Plan Revicw, Criteria } \\
\text { (Building sitcs shall, to the extent } \\
\text { feasible: minimize use of } \\
\text { floodplains...) }\end{array}$ & $\begin{array}{l}\text { Development Plan Review } \\
\text { (adherence to the RI Stormwater } \\
\text { Runoff and RI Erosion and } \\
\text { Sediment Control Handbooks is } \\
\text { required) zo }\end{array}$ & $\begin{array}{l}\text { Devclopment Plan Review, } \\
\text { Ecological Considerations (The } \\
\text { development insofar as } \\
\text { practicable shall conform with } \\
\text { existing geological and } \\
\text { topographical features, to the } \\
\text { end that the most appropriate } \\
\text { use of land is encouraged) zo }\end{array}$ \\
\hline Performance Principles & $\begin{array}{l}\text { Pcrformance Standards, Water } \\
\text { bodies (No facility designed to } \\
\text { leach liquid wastes into the soil } \\
\text { shall be located in that area of } \\
\text { land defined as a } 100 \text { year flood } \\
\text { hazard boundary 'Zone A on the } \\
\text { official Flood Insurance Rate } \\
\text { Maps) zo }\end{array}$ & $\begin{array}{l}\text { Hazardous Waste Management } \\
\text { Facilities, Siting Restrictions (shall } \\
\text { be prohibited in environmentally } \\
\text { sensitive areas) }\end{array}$ & & \\
\hline
\end{tabular}




\begin{tabular}{|c|c|c|c|c|}
\hline Topography & & & & \\
\hline $\begin{array}{l}\text { Erosion and Sediment } \\
\text { Control Plan }\end{array}$ & $\begin{array}{l}\text { Erosion and Sediment Control Plan } \\
\text { (for all major subdivisions and land } \\
\text { development and for all development } \\
\text { where slope exceeds } 15 \% \text { ) }\end{array}$ & $\begin{array}{l}\text { Erosion and Sediment Control Plan } \\
\text { (required for all land developments and } \\
\text { subdivisions prior to any clearing of } \\
\text { land) }\end{array}$ & $\begin{array}{l}\text { Erosion and Sediment Control } \\
\text { Performance Principles (Development } \\
\text { plans shall preserve salient natural } \\
\text { features, keep cut and fill operations to a } \\
\text { minimum and ensure conformity with } \\
\text { topography so as to adequately handle } \\
\text { the volume and velocity of surface water } \\
\text { runoff, and create the least erosion } \\
\text { potential) }\end{array}$ & $\begin{array}{l}\text { - Erosion and Sediment Control } \\
\text { Plan (required for all major land } \\
\text { developments as well as minor and } \\
\text { administrative subdivisions if } \\
\text { deemed necessary by planning } \\
\text { board) }\end{array}$ \\
\hline $\begin{array}{l}\text { Land Unsuitable for } \\
\text { Development }\end{array}$ & $\begin{array}{l}\text { Land Unsuitable for Development } \\
\text { (any area of ledge and/or rock } \\
\text { outcrops at/or within four feet of the } \\
\text { land surface; any area where slopes } \\
\text { exceed } 15 \% \text { ) }\end{array}$ & $\begin{array}{l}\text { Land Unsuitable for Development } \\
\text { (land containing steep slopes in excess } \\
\text { of } 20 \% \text { within any } 10 \text { feet interval on } \\
\text { the contour drawing) }\end{array}$ & & $\begin{array}{l}\text { Land Unsuitable for Development } \\
\text { (land with slopes in excess of } 15 \\
\text { percent) }\end{array}$ \\
\hline $\begin{array}{l}\text { Environmental } \\
\text { Analysis/Impact } \\
\text { Statement }\end{array}$ & $\begin{array}{l}\text { Environmental Analysis (required for } \\
\text { all major subdivisions and land } \\
\text { developments and where slope } \\
\text { exceeds } 15 \% \text { on greater than } 25 \% \text { of } \\
\text { the development) }\end{array}$ & $\begin{array}{l}\text { ERT (Environmental Review Team } \\
\text { Report) may be required by Planning } \\
\text { Commission. }\end{array}$ & $\begin{array}{l}\text { General Requirements, Project } \\
\text { description and impact statement } \\
\text { (Narrative description and impact report } \\
\text { required for all major subdivisions and } \\
\text { land developments; an EIS may be } \\
\text { required for any development at the } \\
\text { request of the Planning Board) } \\
\end{array}$ & $\begin{array}{l}\text { Impact Statement ( may be } \\
\text { required if there is reasonable } \\
\text { expectation of a significant } \\
\text { negative environmental impact on } \\
\text { natural systems) }\end{array}$ \\
\hline Site Design & $\begin{array}{l}\text { Design Standards (Development shall } \\
\text { minimize adverse effects upon the } \\
\text { natural or existing topography and } \\
\text { soils conditions to minimize the } \\
\text { potential for erosion; grading and } \\
\text { other site preparation shall be kept to } \\
\text { an absolute minimums; excess } \\
\text { cutting, filling or stripping vegetation } \\
\text { shall not be permitted) }\end{array}$ & $\begin{array}{l}\text { - Site Design (preferred preservation of } \\
\text { steep slopes in excess of } 20 \% \text { as } \\
\text { undeveloped open space or lot area; } \\
\text { site analysis require for all major } \\
\text { subdivisions and minor subdivisions by } \\
\text { request of the Planning Commission) } \\
\text { - Site Design, Site Analysis (required for } \\
\text { all major subdivisions and minor } \\
\text { subdivisions by request of the Planning } \\
\text { Commission, developer must include } \\
\text { written and/or graphic analysis of } \\
\text { topography and an assessment } \\
\text { describing potential effects of the } \\
\text { proposed development) }\end{array}$ & $\begin{array}{l}\text { Land development and subdivision } \\
\text { design standards, specific, Lots (slopes } \\
\text { over } 12 \% \text {, and bedrock areas may be a } \\
\text { determining factor in effecting lot size } \\
\text { due to the effect this has on onsite } \\
\text { (proposed) sewage systems) }\end{array}$ & $\begin{array}{l}\text { - Site Design (The following areas } \\
\text { shall be preserved as undeveloped } \\
\text { open space or lot area, to the } \\
\text { extent consistent with the } \\
\text { reasonable utilization of land- steep } \\
\text { slopes in excess of } 15 \% \text { unless } \\
\text { appropriate engineering measures } \\
\text { are taken into consideration }\end{array}$ \\
\hline
\end{tabular}




\begin{tabular}{|c|c|c|c|c|}
\hline $\begin{array}{c}\text { Natural Resource } \\
\text { Protection }\end{array}$ & Charlestown & Coventry & Exeter & Hopkinton \\
\hline \multicolumn{5}{|l|}{$\begin{array}{l}\text { Topography } \\
\text { (continued) }\end{array}$} \\
\hline Site Plan Review & $\begin{array}{l}\text { Site Plan Review, Standards, } \\
\text { Environmental Constraints } \\
\text { (development shall avoid areas of } \\
\text { high groundwater, soils with } \\
\text { excessively slow or fast percolation, } \\
\text { ridgelines) }\end{array}$ & $\begin{array}{l}\text { Development Plan Review, Criteria } \\
\text { (Building sites shall, to the extent } \\
\text { feasible: minimize use of steep } \\
\text { slopes...minimize tree, vegetation and } \\
\text { soil removal, grade changes and } \\
\text { subsequent erosion) }\end{array}$ & $\begin{array}{l}\text { Development Plan Review, } \\
\text { Landscaping (The landscape shall be } \\
\text { preserved in its natural state insofar as } \\
\text { practicable by minimizing tree removal, } \\
\text { disturbance of the soil and retaining } \\
\text { existing vegetation during and after } \\
\text { construction; Existing trees and } \\
\text { vegetation shall be preserved to the } \\
\text { maximum extent possible) zo }\end{array}$ & $\begin{array}{l}\text { Development Plan Review, } \\
\text { Ecological Considerations (The } \\
\text { development insofar as practicable } \\
\text { shall: result in minimum adverse } \\
\text { impact upon the critical areas such } \\
\text { as... highly erodible soils; shall } \\
\text { conform with existing geological } \\
\text { and topographical features, to the } \\
\text { end that the most appropriate use } \\
\text { of land is encouraged) zo }\end{array}$ \\
\hline \multicolumn{5}{|l|}{$\begin{array}{l}\text { Rare Species/ } \\
\text { Critical Habitat }\end{array}$} \\
\hline $\begin{array}{l}\text { Land Unsuitable for } \\
\text { Development }\end{array}$ & - Land Unsuitable for Development & & & \\
\hline $\begin{array}{l}\text { Environmental } \\
\text { Analysis/ Impact } \\
\text { Statement }\end{array}$ & - Environmental Analysis (required) & $\begin{array}{l}\text { ERT (Environmental Review Team } \\
\text { Report) may be required by Planning } \\
\text { Commission. }\end{array}$ & $\begin{array}{l}\text { General Requirements, Project } \\
\text { description and impact statement } \\
\text { (Narrative description and impact } \\
\text { report required for all major } \\
\text { subdivisions and land developments; } \\
\text { an EIS may be required for any } \\
\text { development at the request of the } \\
\text { Planning Board or if site is identified } \\
\text { by DEM's Natural Heritage Program) }\end{array}$ & $\begin{array}{l}\text { Impact State (may be required if } \\
\text { there is reasonable expectation of a } \\
\text { significant negative environmental } \\
\text { impact on natural systems) }\end{array}$ \\
\hline
\end{tabular}


REGUI A'TORY COMPARISON BY NA'TURAI, RESOURCE AREA AND PRO'TECIITON MEASURE

\begin{tabular}{|c|c|c|c|c|}
\hline $\begin{array}{c}\text { Natural Resource } \\
\text { Protection } \\
\end{array}$ & Charlestown & Coventry & Exeter & Hopkinton \\
\hline $\begin{array}{l}\text { Rare Species/ } \\
\text { Critical Habitat } \\
\text { (continued) }\end{array}$ & & & & \\
\hline Site Design & $\begin{array}{l}\text { Physical Design and Public } \\
\text { Improvement Standards (existing } \\
\text { features such as woodlands, wetlands, } \\
\text { cemeteries, wildflower sites, } \\
\text { archeological sites, areas of unique } \\
\text { botanical interest and similar } \\
\text { irreplaceable assets, shall be preserved } \\
\text { in the design of the subdivision) }\end{array}$ & $\begin{array}{l}\text { - Site Design (preferred preservation of } \\
\text { habitats of endangered wildlife as } \\
\text { undeveloped open space or lot area) } \\
\text { Site Design (preferred preservation of } \\
\text { significant trees or stands of trees, or } \\
\text { other vegetative species that are rare to } \\
\text { the area or are of particular horticultural } \\
\text { or landscape value as undeveloped open } \\
\text { space or lot areas site analysis require for } \\
\text { all major subdivisions and minor } \\
\text { subdivisions by request of the Planning } \\
\text { Commission) } \\
\text { - Site Design, Site Analysis (developer } \\
\text { must include written and/or graphic } \\
\text { analysis of wetlands, ecology and } \\
\text { existing vegetation and an assessment } \\
\text { describing potential effects of the } \\
\text { proposed development) }\end{array}$ & & $\begin{array}{l}\text { Site Design (habitats of endangered } \\
\text { wildlife, as identified on applicable } \\
\text { federal or state lists shall be } \\
\text { preserved as undeveloped open } \\
\text { space where feasible) }\end{array}$ \\
\hline Site Plan Review & $\begin{array}{l}\text { Site Plan Review, Standards, Historic } \\
\text { and Archaeological Areas (There shall } \\
\text { not be any adverse effect on the } \\
\text { scenic or natural beauty of the areas. } \\
\text { Historical sites, specimen vegetation } \\
\text { and rare and irreplaceable natural } \\
\text { areas shall not be disturbed) }\end{array}$ & $\begin{array}{l}\text { Development Plan Review, Criteria } \\
\text { (Building sites shall, to the extent } \\
\text { feasible: minimize tree, vegetation and } \\
\text { soil removal; preserve unique natural } \\
\text { features...) }\end{array}$ & $\begin{array}{l}\text { Development Plan Review (states that } \\
\text { there must not be any undue adverse } \\
\text { effect on the scenic or natural beauty } \\
\text { of the project area, aesthetics, historic } \\
\text { sites, or rare and irreplaceable natural } \\
\text { areas) zo }\end{array}$ & $\begin{array}{l}\text { Development Plan Review, Design } \\
\text { Standards (The development insofar } \\
\text { as practicable shall result in minimal } \\
\text { degradation of unique or } \\
\text { irreplaceable land types and in } \\
\text { minimum adverse impact upon the } \\
\text { critical areas such as... mature } \\
\text { stands of vegetation, and } \\
\text { extraordinary wildlife nesting, } \\
\text { feeding, or breeding grounds) zo }\end{array}$ \\
\hline Other & $\begin{array}{l}\text { - Plan approval requires a verification } \\
\text { letter from DEM's Natural Heritage } \\
\text { Program zo }\end{array}$ & & $\begin{array}{l}\text { Master Plan approval requires a } \\
\text { verification letter from DEM's } \\
\text { Natural Heritage Program zo }\end{array}$ & \\
\hline
\end{tabular}


REGULA TORY COMPARISON BY NATURAL RESOURCE AREA AND PROTEC'ITON MEASURF

\begin{tabular}{|c|c|c|c|c|}
\hline $\begin{array}{c}\text { Natural Resource } \\
\text { Protection }\end{array}$ & Charlestown & Coventry & Exeter & Hopkinton \\
\hline
\end{tabular}

\begin{tabular}{|c|c|c|c|c|}
\hline \multicolumn{5}{|l|}{ Trees/Woodlands } \\
\hline $\begin{array}{l}\text { Erosion and Sediment } \\
\text { Control Plan }\end{array}$ & $\begin{array}{l}\text { Erosion and Sediment Control } \\
\text { Performance Principles (Natural } \\
\text { vegetation and features shall be } \\
\text { retained and protected). }\end{array}$ & $\begin{array}{l}\text { Erosion and Sediment Control Plan } \\
\text { (required for all land developments and } \\
\text { subdivisions prior to any clearing of } \\
\text { land) }\end{array}$ & $\begin{array}{l}\text { Erosion and Sediment Control } \\
\text { Performance Principles (Whenever } \\
\text { feasible, natural vegetation shall be } \\
\text { retained, protected, and supplemented) }\end{array}$ & $\begin{array}{l}\text { Erosion and Sediment Control } \\
\text { Plan, Performance Principles: } \\
\text { (Trees and other existing } \\
\text { vegetation shall be retained } \\
\text { whenever feasible; the area } \\
\text { within the dripline shall be } \\
\text { fenced or roped off to protect } \\
\text { tress from construction } \\
\text { equipment) } \\
\text { - (See also Development Plan } \\
\text { Review) zo }\end{array}$ \\
\hline \multicolumn{5}{|l|}{$\begin{array}{l}\text { Environmental } \\
\text { Analysis/ } \\
\text { Impact Statement }\end{array}$} \\
\hline Site Design & $\begin{array}{l}\text { Physical Design and Public } \\
\text { Improvement Standards } \\
\text { (existing features such as } \\
\text { woodlands, wildflower sites, } \\
\text { areas of unique botanical interest } \\
\text { and similar irreplaceable assets, } \\
\text { shall be preserved in the design } \\
\text { of the subdivision; where natural } \\
\text { tree growth is insufficient, the } \\
\text { applicant will be required to } \\
\text { plant street trees) }\end{array}$ & $\begin{array}{l}\text { Site Design (preferred preservation of } \\
\text { significant trees or stands of trees, or } \\
\text { other vegetative species that are rare to } \\
\text { the area or are of particular } \\
\text { horticultural or landscape value as } \\
\text { undeveloped open space or lot area; } \\
\text { site analysis require for all major } \\
\text { subdivisions and minor subdivisions by } \\
\text { request of the Planning Commission) }\end{array}$ & & $\begin{array}{l}\text { - Site Design standards } \\
\text { (significant trees or stands of } \\
\text { trees, or other vegetative } \\
\text { species that are rare to the area } \\
\text { or are of particular horticultural } \\
\text { or landscape value shall be } \\
\text { preserved as undeveloped open } \\
\text { space where feasible) } \\
\text { Lot Development Standards } \\
\text { (for administrative subdivisions } \\
\text { may require preservation of } \\
\text { historic, unique natural features } \\
\text { such as trees or stone walls) }\end{array}$ \\
\hline
\end{tabular}




\begin{tabular}{|c|c|c|c|c|}
\hline $\begin{array}{c}\text { Natural Resource } \\
\text { Protection } \\
\end{array}$ & Charlestown & Coventry & Exeter & Hopkinton \\
\hline \multicolumn{5}{|l|}{$\begin{array}{l}\text { Trees/Woodlands } \\
\text { (continued) }\end{array}$} \\
\hline Site Plan Review & $\begin{array}{l}\text { Site Plan Review, Standards, } \\
\text { Historic and Archaeological } \\
\text { Areas--required for all } \\
\text { nonresidential developments } \\
\text { (There shall not be any adverse } \\
\text { effect on the scenic or natural } \\
\text { beauty of the areas. Historical } \\
\text { sites, specimen vegetation and } \\
\text { rare and irreplaceable natural } \\
\text { areas shall not be disturbed) }\end{array}$ & $\begin{array}{l}\text { Development Plan Review, Criteria } \\
\text { (Building sites shall, to the extent } \\
\text { feasible: minimize tree, vegetation } \\
\text { and soil removal; preserve unique } \\
\text { natural features...) }\end{array}$ & $\begin{array}{l}\text { Development Plan Review } \\
\text { (landscape plan requirements state } \\
\text { that existing trees and vegetation } \\
\text { shall be preserved to the maximum } \\
\text { extent possible; the plan must } \\
\text { include the approximate location } \\
\text { of wooded areas, wetlands and } \\
\text { coastal features) zo }\end{array}$ & $\begin{array}{l}\text { Development Plan Review, } \\
\text { Ecological Considerations (The } \\
\text { development insofar as } \\
\text { practicable shall result in } \\
\text { minimal degradation of unique } \\
\text { or irreplaceable land types and in } \\
\text { minimum adverse impact upon } \\
\text { the critical areas such as... } \\
\text { mature stands of vegetation, and } \\
\text { extraordinary wildlife nesting, } \\
\text { feeding, or breeding grounds) zo } \\
\text { Development Plan Review, } \\
\text { Landscape (The landscape shall } \\
\text { be preserved in its natural state } \\
\text { insofar as practicable by } \\
\text { minimizing tree removal, } \\
\text { disturbance of the soil, and } \\
\text { retaining the existing vegetation } \\
\text { during and after construction...) } \\
\text { zo }\end{array}$ \\
\hline Other & & & & $\begin{array}{l}\text { A } 100 \text { foot buffer is required } \\
\text { around the perimeter of a } \\
\text { residential cluster development }\end{array}$ \\
\hline
\end{tabular}


REGULATORY COMPARISON BY NATURAL RFSOURCE AREA AND PRO'IECT'TON MEASURF.

\begin{tabular}{|c|c|c|c|c|}
\hline $\begin{array}{c}\text { Natural Resource } \\
\text { Protection }\end{array}$ & Charlestown & Coventry & Exeter & Hopkinton \\
\hline
\end{tabular}

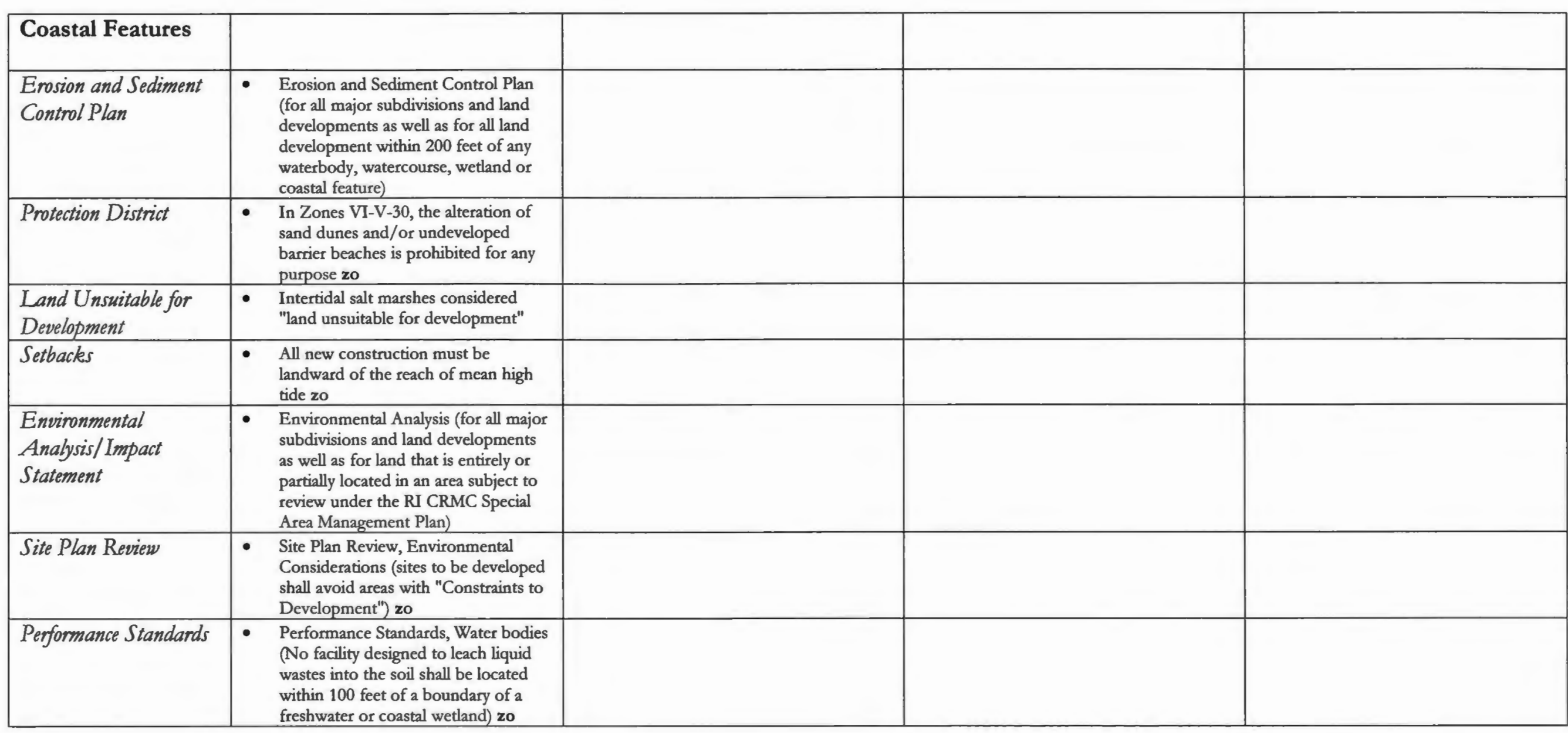


REGULATORY COMPARISON BY NATURAL RESOURCE AREA AND PROTECITON MEASURF.

\begin{tabular}{|c|c|c|c|c|}
\hline $\begin{array}{c}\text { Natural Resource } \\
\text { Protection }\end{array}$ & Charlestown & Coventry & Exeter & Hopkinton \\
\hline
\end{tabular}

\begin{tabular}{|c|c|c|c|c|}
\hline $\begin{array}{l}\text { Village/Rural } \\
\text { Character }\end{array}$ & & & & \\
\hline Overlay Districts & - Historic Village Overlay District zo & & $\begin{array}{ll}\text { - Conservation-Recreation District (CR- } \\
\text { 5) zo } \\
\text { - Village Center Districts zo }\end{array}$ & \\
\hline $\begin{array}{l}\text { Cluster, Residential } \\
\text { Compounds, Planned } \\
\text { Unit Developments, } \\
\text { Low Density Zoning }\end{array}$ & $\begin{array}{l}\text { - The Planned Development District } \\
\text { (rural and natural resource protection } \\
\text { is a stated goal) zo } \\
\text { - Mandatory Cluster zo } \\
\text { - General Requirements, Residential } \\
\text { Cluster Subdivision (open space shall } \\
\text { be used to preserve existing features } \\
\text { of the parcel or structures on the } \\
\text { parcel that have ecological, historic, } \\
\text { archeological, scenic, or cultural } \\
\text { value) } \\
\text { - Residential Compounds zo }\end{array}$ & $\begin{array}{l}\text { RR-5 Zone--Residential } 5 \text { Acres } \\
\text { (designed to preserve the rural } \\
\text { character and to protect } \\
\text { environmentally sensitive land) zo } \\
\text { Planned Unit Development (intended } \\
\text { to establish multi-family residential and } \\
\text { mixed use communities, to promote } \\
\text { attractive, convenient and efficient } \\
\text { development...and to preserve open } \\
\text { space, historic sites and valuable } \\
\text { natural features of the land) zo }\end{array}$ & $\begin{array}{l}\text { RU-4 (Rural District)--The stated } \\
\text { purpose of the district is to protect } \\
\text { land now used for forestry, farming, } \\
\text { and related activities and the natural } \\
\text { habitat and wildlife and to preserve the } \\
\text { area's rural character. zo }\end{array}$ & $\begin{array}{ll}\text { - Residential Cluster Development zo } \\
\text { - Residential Compounds (stated } \\
\text { purpose is rural preservation) zo }\end{array}$ \\
\hline $\begin{array}{l}\text { Land Unsuitable for } \\
\text { Development }\end{array}$ & $\begin{array}{l}\text { - Any unique sites having archeological } \\
\text { or historic value considered "land } \\
\text { unsuitable for development" }\end{array}$ & & & \\
\hline $\begin{array}{l}\text { Environmental } \\
\text { Analysis/Impact } \\
\text { Statement }\end{array}$ & & $\begin{array}{l}\text { Environmental Review Team Report } \\
\text { (The Planning Commission. may } \\
\text { require the applicant to pay for an ERT } \\
\text { prepared by the RI Resource } \\
\text { Conservation and Development } \\
\text { Council, Inc.--if all or part of the } \\
\text { property is identified in the Natural } \\
\text { and Cultural Resources Element of the } \\
\text { Comprehensive Plan...) }\end{array}$ & & $\begin{array}{l}\text { - Impact Statement (may be required } \\
\text { to protect historic/archeological and } \\
\text { natural heritage sites) }\end{array}$ \\
\hline
\end{tabular}




\begin{tabular}{|c|c|c|c|c|}
\hline $\begin{array}{l}\text { Village/Rural } \\
\text { Character } \\
\text { (continued) }\end{array}$ & & & & \\
\hline Site Design & $\begin{array}{l}\text { Physical Design and Public } \\
\text { Improvement Standards (existing } \\
\text { features such as woodlands, wetlands, } \\
\text { cemeteries, wildflower sites, } \\
\text { archeological sites, areas of unique } \\
\text { botanical interest and similar } \\
\text { irreplaceable assets, shall be preserved } \\
\text { in the design of the subdivision) }\end{array}$ & $\begin{array}{l}\text { - Site Design (preferred preservation of } \\
\text { historically significant structures and } \\
\text { sites as undeveloped open space or lot } \\
\text { area; significant trees or stands of trees, } \\
\text { or other vegetative species that are rare } \\
t \text { the area or are of horticultural or } \\
\text { landscape value; site analysis require } \\
\text { for all major subdivisions and minor } \\
\text { subdivisions by request of the Planning } \\
\text { Commission) } \\
\text { - Site Design, Landscape Design } \\
\text { (Reasonable landscaping should be } \\
\text { provided at site entrances, in public } \\
\text { areas, and adjacent to buildings...)ro }\end{array}$ & & $\begin{array}{l}\text { Site Design standards (historically } \\
\text { significant structures and sites, as } \\
\text { listed on federal or state lists of } \\
\text { historic places shall be preserved as } \\
\text { undeveloped open space where } \\
\text { feasible) } \\
\text { Lot Development Standards (for } \\
\text { administrative subdivisions may } \\
\text { require preservation of historic, } \\
\text { unique natural features such as trees } \\
\text { or stone walls) }\end{array}$ \\
\hline Site Plan Review & $\begin{array}{l}\text { Site Plan Review, Standards, } \\
\text { (proposed developments shall relate } \\
\text { to the natural terrain and be visibly } \\
\text { compatible with the rural character of } \\
\text { the community) zo } \\
\text { Site Plan Review, Standards, Historic } \\
\text { and Archaeological Areas--required } \\
\text { for all nonresidential developments } \\
\text { zo } \\
\text { Site Plan Review, Standards, Building } \\
\text { Design and Location (Proposed } \\
\text { structures shall be related } \\
\text { harmoniously to the terrain and to the } \\
\text { existing buildings in the vicinity which } \\
\text { have a visual relationship to the } \\
\text { proposed buildings) zo } \\
\text { Site Plan Review (standards call for } \\
\text { protection of scenic roadways and } \\
\text { vistas) }\end{array}$ & $\begin{array}{l}\text { Development Plan Review, Criteria } \\
\text { (Architectural style shall be in harmony } \\
\text { with the prevailing character and scale } \\
\text { of buildings in the neighborhood and } \\
\text { the town through the use of } \\
\text { appropriate building materials, } \\
\text { screening, breaks in roof and wall lines } \\
\text { and other architectural techniques; } \\
\text { minimize tree, vegetation and soil } \\
\text { removal, grade changes and subsequent } \\
\text { erosion; preserve unique natural or } \\
\text { historical features; minimize } \\
\text { obstruction of scenic view from } \\
\text { publicly accessible locations) }\end{array}$ & $\begin{array}{l}\text { Development Plan Review (states that } \\
\text { there must not be any undue adverse } \\
\text { effect on the scenic or natural beauty } \\
\text { of the project area, aesthetics, historic } \\
\text { sites, or rare and irreplaceable natural } \\
\text { areas; see also architectural and } \\
\text { landscape standards) zo }\end{array}$ & $\begin{array}{l}\text { Architectural Standards of Review } \\
\text { (within Development Plan Review } \\
\text { excluding single and two-family } \\
\text { dwellings) }\end{array}$ \\
\hline
\end{tabular}


REGULA'TORY COMPARISON BY NATURAL RESOURCE AREA AND PRO'TECITION MEASURE

\begin{tabular}{|c|}
\hline $\begin{array}{c}\text { Natural Resource } \\
\text { Protection }\end{array}$ \\
\hline
\end{tabular}

Charlestown

Coventry

Exeter

Hopkinton

\begin{tabular}{|l|l|l|l|l|}
\hline $\begin{array}{l}\text { Village/Rural } \\
\text { Charater } \\
\text { (continued) }\end{array}$ & & & \\
\hline Historic Preservation & $-\quad$ See Site Plan Review Above & & $\begin{array}{l}\text { Historic Sites and Structures must be } \\
\text { identified in the preliminary plan for a } \\
\text { minor or major subdivision/land } \\
\text { development }\end{array}$ \\
\hline Landscaping Standards & $-\quad$ See Site Plan Review (Landscape) & & $\begin{array}{l}\text { Landscaping Requirements (shade } \\
\text { trees/shrubs where no natural growth } \\
\text { exists within 10 feet of the right-of- } \\
\text { way) }\end{array}$ \\
\hline Street Design & $\begin{array}{l}\text { Shared private drives (are } \\
\text { encouraged) } \\
\text { Street Design Standards (Gridion } \\
\text { street patterns are not permitted; all } \\
\text { strets shall be related to population } \\
\text { densities) }\end{array}$ & & & \\
\hline
\end{tabular}


REGULATORY COMPARISON BY NATURAL RESOURCE AREA AND PROTECTION MEASURE

\begin{tabular}{|c|c|c|c|c|}
\hline $\begin{array}{c}\text { Natural Resource } \\
\text { Protection }\end{array}$ & Richmond & South Kingstown & Westerly & West Greenwich \\
\hline
\end{tabular}

\begin{tabular}{|c|c|c|c|c|}
\hline $\begin{array}{l}\text { Land } \\
\text { Conservation }\end{array}$ & & & & \\
\hline \multicolumn{5}{|l|}{$\begin{array}{l}\text { Farmland } \\
\text { Preservation }\end{array}$} \\
\hline Zoning Regulations & $\begin{array}{l}\text { Agricultural Overtay District (single } \\
\text { family development is perrinitted by } \\
\text { right: a minimum of } 50 \text { gross acres is } \\
\text { required for both residential cluster } \\
\text { developenments and residential } \\
\text { compounds) zo }\end{array}$ & $\begin{array}{l}\text { - R200 Zone (may discourage conversion of } \\
\text { open space and farmlands) }\end{array}$ & & \\
\hline Site Design & $\begin{array}{l}\text { - Site Design Standards (call for } \\
\text { agricultural lands to be preserved as } \\
\text { undeveloped open space or lot area) } \\
\text { Criteria for Review for } 2 \text { lot } \\
\text { subdivision (Planning board shall } \\
\text { maximizize preservation of } \\
\text { agricultural lands and Prime } \\
\text { Farmland) }\end{array}$ & $\begin{array}{ll}\text { - Site Design Standards (may require } \\
\text { preservation efforts) } \\
\text { Lot Development Standards (Minor } \\
\text { Subdivision Criteria for Review may } \\
\text { include "Preservation of Agricultural } \\
\text { Land" through clustering requirements }\end{array}$ & $\begin{array}{l}\text { Site Design Standards (preferred } \\
\text { preservation of agricultural land in site } \\
\text { design) }\end{array}$ & $\begin{array}{l}\text { - } \\
\text { Site Design Standards (calls for specific } \\
\text { areas to be preserved as open space } \\
\text { including agricultural lands) } \\
\text { Criteria for Review--3 to } 5 \text { lot minor } \\
\text { subdivision (includes cluster provisions } \\
\text { for preservation of prime farmland or } \\
\text { farmland of statewide importance) }\end{array}$ \\
\hline \multicolumn{5}{|l|}{$\begin{array}{l}\text { Open Space } \\
\text { Zoning }\end{array}$} \\
\hline & - No & 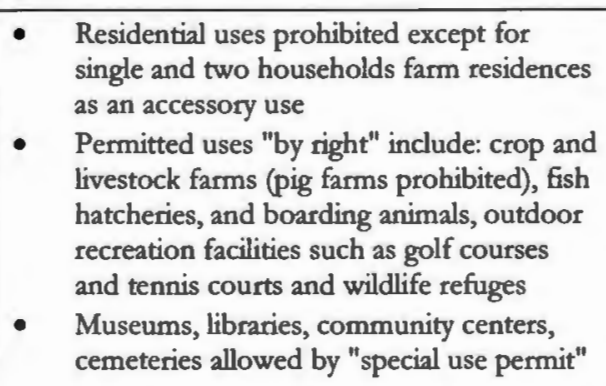 & $\begin{array}{l}\text { - Permitted uses by "special use permit" } \\
\text { include: Public Parks and Recreation, } \\
\text { Golf Courses. Municipal Buildings and } \\
\text { Cemeteries }\end{array}$ & $\begin{array}{l}\text { - Recreational Facilities allowed by } \\
\text { "special use permit" }\end{array}$ \\
\hline
\end{tabular}




\begin{tabular}{|c|c|c|c|c|}
\hline $\begin{array}{l}\text { Open Space } \\
\text { Preservation }\end{array}$ & & & & \\
\hline $\begin{array}{l}\text { Cluster Development, } \\
\text { Residential Compounds, } \\
\text { Large Lot Zoning }\end{array}$ & $\begin{array}{l}\text { Cluster required for all major } \\
\text { subdivisions ( } 40 \% \text { of the gross area } \\
\text { must be preserved as open space; no } \\
\text { more than } 25 \% \text { of the minimum } \\
\text { open space can be land unsuitable } \\
\text { for development) zo }\end{array}$ & $\begin{array}{l}\text { Residential cluster developments and } \\
\text { compounds are permitted uses in the R20, } \\
30,40,80 \text { and } 200 \text { districts ( } 40 \% \text { of the } \\
\text { gross area must be open space, not } \\
\text { including stormwater drainage facilities; no } \\
\text { more than } 50 \% \text { of the open space can be } \\
\text { land unsuitable for development) } \\
\text { Planning Board can require cluster } \\
\text { development for a particular subdivision }\end{array}$ & $\begin{array}{l}\text { Residential cluster development is } \\
\text { permitted in the RR-60, LDR-43, LDR- } \\
40 \text { and MDR-30 zoning districts } \\
\text { (minimum land area is } 10 \text { acres; if it } \\
\text { includes private roads, } 25 \text { acres is } \\
\text { required) zo } \\
\text { Residential cluster development } \\
\text { (developer must demonstrate clustering } \\
\text { would be a better use of the land than a } \\
\text { conventional subdivision (no minimum } \\
\text { open space requirement) zo }\end{array}$ & \\
\hline $\begin{array}{l}\text { Land Unsuitable for } \\
\text { Development }\end{array}$ & $\begin{array}{l}\text { Land Unsuitable for Development } \\
\text { (is deducted from the buildable } \\
\text { acreage of the parcel--freshwater } \\
\text { wetlands, except that area of } \\
\text { perimeter wetland within } 50 \text { feet of } \\
\text { the edge of any bog, marsh, swamp } \\
\text { or pond; or any applicable } 100 \text { foot } \\
\text { or } 200 \text { foot riverbank wetlands; } \\
\text { areas within a High Flood Danger } \\
\text { zone; land within any publicly or } \\
\text { privately held easement on which } \\
\text { above-ground utilities, including but } \\
\text { not limited to electrical transmission } \\
\text { lines, are constructed) }\end{array}$ & $\begin{array}{l}\text { - Land Unsuitable for Development (shall } \\
\text { not be counted toward the minimum lot } \\
\text { size requirements-- freshwater wetlands, } \\
\text { except that area of perimeter wetland } \\
\text { within } 50 \text { feet of the edge of any bog, } \\
\text { marsh, swamp or pond; or any applicable } \\
100 \text { foot or } 200 \text { foot riverbank wetlands; } \\
\text { coastal wetlands except any directly } \\
\text { associated contiguous areas; areas within a } \\
\text { High Flood Danger zone; land within any } \\
\text { publicly or privately held easement on } \\
\text { which above ground utilities, including but } \\
\text { not limited to electrical transmission lines, } \\
\text { are constructed) }\end{array}$ & $\begin{array}{l}\text { Land Unsuitable for Development (may } \\
\text { be deducted from the minimum building } \\
\text { acreage of the parcel--freshwater } \\
\text { wetlands, coastal wetlands, land within } \\
\text { an easement, areas within the } 100 \text { year } \\
\text { flood zone and areas with soils that } \\
\text { exceed } 15 \% \text { slope) }\end{array}$ & $\begin{array}{l}\text { - Lands Unsuitable for } \\
\text { Development (shall not be } \\
\text { counted toward the minimum lot } \\
\text { size requirements; it may be } \\
\text { included as part of any lot in any } \\
\text { subdivision or land development } \\
\text { project; provided that land } \\
\text { unsuitable for development shall } \\
\text { not exceed } 30 \% \text { of the minimum } \\
\text { lot size required in the zoning } \\
\text { ordinance--freshwater wetlands, } \\
\text { except that area of perimeter } \\
\text { wetland within } 50 \text { feet of the edge } \\
\text { of any bog, marsh, swamp or } \\
\text { pond; or any applicable } 100 \text { foot } \\
\text { or } 200 \text { foot niverbank wetlands; } \\
\text { areas within a } 100 \text { year flood } \\
\text { zone; land within any publicly or } \\
\text { privately held easement on which } \\
\text { above ground utilities, including } \\
\text { but not limited to electrical } \\
\text { transmission lines; areas which } \\
\text { exceed } 15 \% \text { slope) }\end{array}$ \\
\hline
\end{tabular}


REGULATORY COMPARISON BY NATURAL RESOURCE AREA AND PROTECTION MEASURE Natural Resource

Protection

Richmond

\begin{tabular}{|c|c|c|c|c|}
\hline \multicolumn{5}{|l|}{$\begin{array}{l}\text { Open Space } \\
\text { Preservation } \\
\text { (Continued) }\end{array}$} \\
\hline $\begin{array}{l}\text { Dedication of Land for } \\
\text { Public Purposes }\end{array}$ & $\begin{array}{l}\text { Dedication of Land for Public } \\
\text { Purposes (land dedication, payment } \\
\text { in lieu or both are required; amount } \\
\text { of land to be dedicated is } .01 \\
\text { acres/per person) }\end{array}$ & & $\begin{array}{l}\text { - Dedication of Public Land and } \\
\text { Improvements (see comp.plan) }\end{array}$ & \\
\hline Site Design & & & $\begin{array}{l}\text { - } \quad \text { Site Design Standards (see preferred } \\
\text { areas for preservation) }\end{array}$ & $\begin{array}{l}\text { - Site Design Standards (call for specific } \\
\text { areas to be preserved as open space) }\end{array}$ \\
\hline \multicolumn{5}{|l|}{$\begin{array}{l}\text { Natural Resource } \\
\text { Protection }\end{array}$} \\
\hline Wetlands & $\begin{array}{l}\text { Freshwater wetlands are considered "land } \\
\text { unsuitable for development" }\end{array}$ & & & \\
\hline $\begin{array}{l}\text { Erosion and Sediment } \\
\text { Control Plan }\end{array}$ & & $\begin{array}{l}\text { Erosion and Sediment Control } \\
\text { Performance Principles (Plan is required } \\
\text { for all subdivisions if construction } \\
\text { activities are within } 100 \text { feet of a wetland } \\
\text { or coastal feature) }\end{array}$ & $\begin{array}{l}\text { Erosion and Sediment Control } \\
\text { Plan (all major development as well } \\
\text { as any development activity within } \\
\text { 200 feet of any wetland or coastal } \\
\text { feature) }\end{array}$ & \\
\hline Protection District & & $\begin{array}{l}\text { - Carrying Capacity Overlay District (SAMP } \\
\text { Areas) zo }\end{array}$ & & \\
\hline $\begin{array}{l}\text { Land Unsuitable for } \\
\text { Development }\end{array}$ & & - Land Unsuitable for Development & - Land Unsuitable for Development & - Land Unsuitable for Development \\
\hline $\begin{array}{l}\text { Envirnmental } \\
\text { Analysis/Impact } \\
\text { Analysis }\end{array}$ & $\begin{array}{l}\text { - An EIS may be required (by } \\
\text { authority of the Planning Board) }\end{array}$ & $\begin{array}{l}\text { - Possible EIS required for development in } \\
\text { critical/environmental areas }\end{array}$ & & $\begin{array}{l}\text { EIS (may be required if there is a } \\
\text { reasonable expectation that the } \\
\text { proposed development will have a } \\
\text { significant negative impact on } \\
\text { natural systems) }\end{array}$ \\
\hline
\end{tabular}


REGULATORY COMPARISON BY NATURAL RESOURCE AREA AND PROTECTION MEASURE

\begin{tabular}{|c|c|c|c|c|}
\hline $\begin{array}{c}\text { Natural Resource } \\
\text { Protection }\end{array}$ & Richmond & South Kingstown & Westerly & West Greenwich \\
\hline \multicolumn{5}{|l|}{$\begin{array}{l}\text { Wetlands } \\
\text { (continued) }\end{array}$} \\
\hline Site Design & $\begin{array}{l}\text { Site Design Standards (call for } \\
\text { unique and/or fragile areas, } \\
\text { including freshwater wetlands } \\
\text { to be preserved as undeveloped } \\
\text { open space or lot area) }\end{array}$ & $\begin{array}{ll} & \text { Site Design Standards (may require } \\
\text { preservation efforts) }\end{array}$ & $\begin{array}{l}\text { Site Design Standards (preferred } \\
\text { preservation of wetlands in site design) }\end{array}$ & $\begin{array}{l}\text { - Site Design Standards (calls for } \\
\text { specific areas to be preserved as } \\
\text { open space including wetlands) }\end{array}$ \\
\hline Site Plan Review & $\begin{array}{l}\text { Development Plan Review } \\
\text { Standards (calls for minimal } \\
\text { adverse impact upon critical } \\
\text { areas; natural features of land } \\
\text { must be shown on the site } \\
\text { plan) zo }\end{array}$ & & & $\begin{array}{l}\text { Site Plan Review (development } \\
\text { shall result in minimal } \\
\text { degradation of unique or } \\
\text { irreplaceable land types; minimal } \\
\text { adverse impact upon the critical } \\
\text { areas such as streams, wetlands, } \\
\text { areas of aquifer recharge and } \\
\text { discharge, steep slopes, highly } \\
\text { erodible soils; areas with a high } \\
\text { water table, mature stands of } \\
\text { vegetation and extraordinary } \\
\text { wildlife nesting, feeding or } \\
\text { breeding grounds) zo }\end{array}$ \\
\hline Performance Standards & & & & $\begin{array}{|ll|}- & \text { Industrial Site and Performance } \\
\text { Standards }\end{array}$ \\
\hline \multicolumn{5}{|l|}{$\begin{array}{l}\text { Watercourses/ } \\
\text { Surface Waters }\end{array}$} \\
\hline $\begin{array}{l}\text { Erosion and Sediment } \\
\text { Control Plan }\end{array}$ & $\begin{array}{l}\text { Erosion and Sediment Control Plan } \\
\text { (required for all major land } \\
\text { developments as well as for minor } \\
\text { or administrative subdivisions if } \\
\text { deemed necessary by the Planning } \\
\text { Board) }\end{array}$ & $\begin{array}{l}\text { Erosion and Sediment Control } \\
\text { Performance Principles (Plan is required } \\
\text { for all subdivisions if construction } \\
\text { activities are within } 100 \text { feet of a wetland } \\
\text { or coastal feature--otherwise, plan is not } \\
\text { required for minor or administrative } \\
\text { subdivisions) }\end{array}$ & $\begin{array}{l}\text { Erosion and Sediment Control (original } \\
\text { boundaries, alignment and slope of } \\
\text { water courses shall be preserved to the } \\
\text { greatest extent possible) }\end{array}$ & \\
\hline Protection District & & $\begin{array}{l}\text { - Carrying Capacity Overlay District (SAMP } \\
\text { Areas) zo }\end{array}$ & $\begin{array}{ll} & \text { River Corridor Overlay zo } \\
\text { - } & \text { Salt Pond Overlay zo }\end{array}$ & \\
\hline
\end{tabular}




\begin{tabular}{|c|c|c|c|c|}
\hline $\begin{array}{c}\text { Natural Resource } \\
\text { Protection }\end{array}$ & Richmond & South Kingstown & Westerly & West Greenwich \\
\hline
\end{tabular}

\begin{tabular}{|c|c|c|c|c|}
\hline $\begin{array}{l}\text { Watercourses/ } \\
\text { Surface Waters } \\
\text { (continued) }\end{array}$ & & & & \\
\hline Setbacks & $\begin{array}{l}\text { - } 50 \text { foot Sewage Disposal Facility } \\
\text { setback (from any waterbody, pond, } \\
\text { stream, brook or river) zo }\end{array}$ & $\begin{array}{l}\text { - Hazardous Waste Facility setback } \\
\text { requirements zo } \\
\text { - Special Use Permits, Location of ISDS (no } \\
\text { facility designed to leach liquid wastes into } \\
\text { the soil shall be located within } 150 \text { feet of } \\
\text { a river...) zo }\end{array}$ & $\begin{array}{l}\text { - Hazardous Waste Management Facility } \\
\text { Siting Requirements (prohibited within } \\
1,000 \text { feet of environmentally sensitive } \\
\text { areas) zo }\end{array}$ & $\begin{array}{l}\text { ISDS Setback Requirements (facilities } \\
\text { which are designed to leach liquid } \\
\text { wastes into the soil shall be located not } \\
\text { less than } 200 \text { feet from the edge of any } \\
\text { pond or stream) zo }\end{array}$ \\
\hline Site Design & & $\begin{array}{l}\text { - Lot Design Standards (stormwater } \\
\text { easements may be required) }\end{array}$ & $\begin{array}{l}\text { Site Design Standards (original } \\
\text { boundaries, alignment and slope of } \\
\text { water courses shall be preserved to the } \\
\text { greatest extent possible) }\end{array}$ & \\
\hline Site Plan Review & $\begin{array}{l}\text { Site Plan Review, Standards-- } \\
\text { required for all nonresidential } \\
\text { activities (measures shall conform to } \\
\text { the minimum standards of the } 1993 \\
\text { State of RI Stormwater Manual) zo }\end{array}$ & & $\begin{array}{l}\text { Development Plan Review (required for } \\
\text { all non-residential uses-a development } \\
\text { plan shall not be approved if it would } \\
\text { result in water pollution, damage to } \\
\text { shoreline vegetation, or inhibition of } \\
\text { public access) zo }\end{array}$ & $\begin{array}{l}\text { - Site Plan Review (development shall } \\
\text { result in minimal adverse impact upon } \\
\text { the critical areas such as streams...) }\end{array}$ \\
\hline Performance Standards & & - Industrial Performance Standards zo & & \\
\hline Other & $\begin{array}{l}\text { Drainage Plan requirements (must } \\
\text { leave existing watercourses open, } \\
\text { unless approval to enclose is granted } \\
\text { by the Planning Board) }\end{array}$ & & $\begin{array}{l}\text { Stormwater Easement or drainage right- } \\
\text { of-way (required where development is } \\
\text { traversed by a water course, drainage } \\
\text { way, channel or stream) }\end{array}$ & \\
\hline
\end{tabular}


REGULATORY COMPARISON BY NATURAL RESOURCE AREA AND PROTECTION MEASURE

\begin{tabular}{|c|c|c|c|c|}
\hline $\begin{array}{c}\text { Natural Resource } \\
\text { Protection }\end{array}$ & Richmond & South Kingstown & Westerly & West Greenwich \\
\hline
\end{tabular}

\begin{tabular}{|c|c|c|c|c|}
\hline $\begin{array}{l}\text { Groundwater/ } \\
\text { Recharge Areas }\end{array}$ & & & & \\
\hline Protection District & $\begin{array}{l}\text { Aquifer Protection District zo } \\
\text { Special Flood Hazard Areas } \\
\text { (Regulations are intended to } \\
\text { minimize hazards to persons and } \\
\text { damage to property from inland and } \\
\text { tidal flooding, to protect floodways } \\
\text { from encroachment, and to maintain } \\
\text { the capacity of floodplains to retain } \\
\text { and carry off floodwaters) zo }\end{array}$ & $\begin{array}{l}\text { - Groundwater Protection Overlay District } \\
\text { zo }\end{array}$ & $\begin{array}{l}\text { - Groundwater Protection Overlay } \\
\text { District zo }\end{array}$ & \\
\hline $\begin{array}{l}\text { Envinonmental } \\
\text { Analysis/Impact } \\
\text { Statement }\end{array}$ & & $\begin{array}{l}\text { EIS (may be required if land is located on } \\
\text { Map } 5.3 \text { of the Comprehensive Plan as } \\
\text { being within a critical or environmentally } \\
\text { sensitive area or by authority of the } \\
\text { Planning Board) }\end{array}$ & & - EIS may be required \\
\hline Setbacks & & & $\begin{array}{l}\text { - Hazardous Waste Management Facility } \\
\text { Siting Requirements (prohibited within } \\
1,000 \text { feet of environmentally sensitive } \\
\text { areas) zo }\end{array}$ & \\
\hline Site Design & $\begin{array}{l}\text { - Site Design Standards (calls for } \\
\text { development to be laid out to avoid } \\
\text { adversely affecting groundwater and } \\
\text { aquifer recharge) }\end{array}$ & $\begin{array}{l}\text { Site Design Standards (siting must avoid } \\
\text { adverse impacts to groundwater and } \\
\text { aquifer recharge) }\end{array}$ & & $\begin{array}{l}\text { Site Design Standards (state that } \\
\text { development should be laid out to } \\
\text { avoid adversely affecting groundwater } \\
\text { and aquifer recharge and to avoid } \\
\text { unnecessary impervious cover) }\end{array}$ \\
\hline Site Plan Review & $\begin{array}{l}\text { Development Plan Review } \\
\text { (standards for ecological protection } \\
\text { of areas of aquifer recharge and } \\
\text { discharge) zo }\end{array}$ & & $\begin{array}{l}\text { Development Plan Review (required for } \\
\text { all non-residential uses--a development } \\
\text { plan shall not be approved if it would } \\
\text { result in water pollution, damage to } \\
\text { shoreline vegetation, or inhibition of } \\
\text { public access) zo }\end{array}$ & $\begin{array}{l}\text { Site Plan Review (development shall } \\
\text { result in minimum degradation } \\
\text { of... areas of aquifer recharge and } \\
\text { discharge; drainage control should } \\
\text { preserve existing natural drainage } \\
\text { patterns and wetlands; and enhance } \\
\text { groundwater recharge areas) zo }\end{array}$ \\
\hline Other & $\begin{array}{l}\text { Residential } 3 \text { Acre Zoning District } \\
\text { (designation is intended to protect } \\
\text { groundwater) zo }\end{array}$ & $\begin{array}{l}\text { - Special Requirements (Residential Cluster } \\
\text { in R200 may be restricted based on } \\
\text { environmental considerations) }\end{array}$ & & \\
\hline
\end{tabular}


REGULATORY COMPARISON BY NATURAL RESOURCE AREA AND PROTECTION MEASURE

\begin{tabular}{|c|c|c|c|c|}
\hline $\begin{array}{c}\text { Natural Resource } \\
\text { Protection }\end{array}$ & Richmond & South Kingstown & Westerly & West Greenwich \\
\hline
\end{tabular}

\begin{tabular}{|c|c|c|c|c|}
\hline \multicolumn{5}{|l|}{ Floodplains } \\
\hline Protection District & $\begin{array}{l}\text { Special Flood Hazard Areas } \\
\text { (Regulations are intended to } \\
\text { minimize hazards to persons and } \\
\text { damage to property from inland and } \\
\text { tidal flooding, to protect floodways } \\
\text { from encroachment, and to maintain } \\
\text { the capacity of floodplains to retain } \\
\text { and carry off floodwaters) zo }\end{array}$ & $\begin{array}{l}\text { High Flood Danger Overlay District } \\
\text { - Carrying Capacity Overlay zo }\end{array}$ & $\begin{array}{l}\text { Flood Hazard Overlay District (no use } \\
\text { shall be approved which would } \\
\text { adversely affect the capacity of any } \\
\text { drainage facility or system or would } \\
\text { involve alteration of sand dunes, barricr } \\
\text { beaches, and other natural protective } \\
\text { barriers) zo }\end{array}$ & \\
\hline $\begin{array}{l}\text { Land Unsuitable for } \\
\text { Development }\end{array}$ & $\begin{array}{l}\text { - Areas within a Iligh Flood Danger } \\
\text { Zone are considered "land } \\
\text { unsuitable for development" }\end{array}$ & - Land Unsuitable for Development & - $\quad$ Land Unsuitable for Development & - Land Unsuitable for Devclopment \\
\hline $\begin{array}{l}\text { Environmental } \\
\text { Analysis/Impact } \\
\text { Statement }\end{array}$ & & $\begin{array}{l}\text { EIS (may be required if land is located on } \\
\text { Map } 5.3 \text { of the Comprehensive Plan as } \\
\text { being within a critical or environmentally } \\
\text { sensitive area or by authority of the } \\
\text { Planning Board) }\end{array}$ & & \\
\hline Setbacks & & $\begin{array}{l}\text { ISDS Siting Restrictions/Sctbacks (no } \\
\text { facility designed to leach liquid wastes into } \\
\text { the soil shall be located within } 150 \text { feet of a } \\
\text { flood plain...) zo }\end{array}$ & & \\
\hline \multicolumn{5}{|l|}{ Site Plan Review } \\
\hline Other & & & & $\begin{array}{l}\text { Design and Public Improvement } \\
\text { Standards (state that development } \\
\text { should be laid out to prevent flooding; } \\
\text { also, the Planning Board shall examine } \\
\text { each proposed subdivision to ensure } \\
\text { that potential flood damage is } \\
\text { minimized, public utilitics and facilities } \\
\text { are clevated and that adequatc drainage } \\
\text { is provided) }\end{array}$ \\
\hline
\end{tabular}


REGULATORY COMPARISON BY NATURAL RESOURCE AREA AND PROTECTION MEASURE

\begin{tabular}{|c|c|c|c|c|}
\hline $\begin{array}{c}\text { Natural Resource } \\
\text { Protection }\end{array}$ & Richmond & South Kingstown & Westerly & West Greenwich \\
\hline
\end{tabular}

\begin{tabular}{|c|c|c|c|c|}
\hline Topography & & & & \\
\hline $\begin{array}{l}\text { Erosion and Sediment } \\
\text { Control Plan }\end{array}$ & & $\begin{array}{l}\text { Erosion and Sediment Control } \\
\text { Performance Principles (Plan is required } \\
\text { for all subdivisions if slopes at the site } \\
\text { exceed } 10 \% \text {-otherwise, plan is not } \\
\text { required for minor or administrative } \\
\text { subdivisions) }\end{array}$ & $\begin{array}{l}\text { Erosion and Sediment Control Plan } \\
\text { (required for all major land } \\
\text { developments/subdivisions and all } \\
\text { subdivisions if slopes are greater than } \\
10 \% \text { ) }\end{array}$ & \\
\hline $\begin{array}{l}\text { Land Unsuitable for } \\
\text { Development }\end{array}$ & & & $\begin{array}{l}\text { - Land Unsuitable for Development } \\
\text { (slopes in excess of } 15 \% \text { ) }\end{array}$ & $\begin{array}{l}\text { Land Unsuitable for Development } \\
\text { (areas that exceed 15\% slope) }\end{array}$ \\
\hline Site Design & & $\begin{array}{l}\text { - Site Design (steep slopes in excess of } 20 \% \\
\text { as measured over a } 10 \text { foot interval unless } \\
\text { appropriate engineering measures } \\
\text { concerning slope stability, erosion, and } \\
\text { resident safety are taken shall be preserved } \\
\text { as open space where feasible) }\end{array}$ & & \\
\hline Site Plan Review & $\begin{array}{l}\text { Development Plan Review, } \\
\text { Ecological Considerations (calls } \\
\text { for minimal adverse impact } \\
\text { upon critical areas such as } \\
\text { steep slopes, highly erodible } \\
\text { soils, areas with a high water } \\
\text { table...)natural features of land } \\
\text { must be shown on the site } \\
\text { plan) zo }\end{array}$ & & & $\begin{array}{l}\text { Site Plan Review (development shall } \\
\text { result in minimal degradation of unique } \\
\text { or irreplaceable land types; minimal } \\
\text { adverse impact upon the critical areas } \\
\text { such as... steep slopes, highly erodible } \\
\text { soils; areas with a high water table, } \\
\text { mature stands of vegetation and } \\
\text { extraordinary wildlife nesting, feeding } \\
\text { or breeding grounds) zo }\end{array}$ \\
\hline
\end{tabular}


REGULATORY COMPARISON BY NATURAL RESOURCE AREA AND PROTECTION MEASURE

\begin{tabular}{|c|c|c|c|c|}
\hline $\begin{array}{c}\text { Natural Resource } \\
\text { Protection }\end{array}$ & Richmond & South Kingstown & Westerly & West Greenwich \\
\hline
\end{tabular}

\begin{tabular}{|c|c|c|c|c|}
\hline $\begin{array}{l}\text { Rare Species/ } \\
\text { Critical Habitat }\end{array}$ & & & & \\
\hline Protection District & & \begin{tabular}{|l|} 
R200 Zone (intended to protect \\
environmentally sensitive areas: aquifers, \\
recharge areas, and coastal ponds)
\end{tabular} & & \\
\hline $\begin{array}{l}\text { Environmental } \\
\text { Analysis/Impact } \\
\text { Statement }\end{array}$ & $\begin{array}{l}\text { - EIS maybe required (including an } \\
\text { assessment of short and long term } \\
\text { environmental impacts on natural } \\
\text { heritage areas and wildlife) }\end{array}$ & $\begin{array}{l}\text { EIS (may be required if land is located on } \\
\text { Map } 5.3 \text { of the Comprehensive Plan as } \\
\text { being w within a critical or environmentally } \\
\text { sensitive area or by authority of the } \\
\text { Planning Board) }\end{array}$ & & - EIS may be required \\
\hline Setbacks & & $\begin{array}{ll}\text { - Hazardous Waste Facility setback } \\
\text { requirements zo }\end{array}$ & & \\
\hline Site Design & $\begin{array}{l}\text { Site Design Standards (require } \\
\text { habitats of endangered wildlife to be } \\
\text { preserved as undeveloped open } \\
\text { space or lot area) }\end{array}$ & $\begin{array}{l}\text { - Site Design (habitat of endangered species } \\
\text { shall be preserved as open space where } \\
\text { feasible; site analysis for all major } \\
\text { developments and subdivisions) }\end{array}$ & $\begin{array}{l}\text { Site Design Standards (preferred } \\
\text { preservation of endangered wildlife } \\
\text { habitat in site design) }\end{array}$ & $\begin{array}{l}\text { - Site Design Standards (call for specific } \\
\text { areas to be preserved as open space } \\
\text { including habitats of endangered } \\
\text { wildlife) }\end{array}$ \\
\hline Site Plan Review & $\begin{array}{l}\text { Development Plan Review, } \\
\text { Ecological Considerations } \\
\text { (standards for ecological protection } \\
\text { of unique or irreplaceable land types } \\
\text { such as extraordinary wildlife } \\
\text { nesting, feeding or breeding } \\
\text { grounds) zo }\end{array}$ & & & $\begin{array}{l}\text { - Site Plan Review (development shall } \\
\text { result in minimal adverse impact } \\
\text { upon....areas of extraordinary wildlife } \\
\text { nesting, feeding or breeding grounds) } \\
\text { zo }\end{array}$ \\
\hline
\end{tabular}


REGULATORY COMPARISON BY NATURAL RESOURCE AREA AND PROTECTION MEASURE

\section{Natural Resource}

Protection

\begin{tabular}{|c|c|c|c|c|}
\hline Trees/Woodlands & & & & \\
\hline $\begin{array}{l}\text { Erosion and Sediment } \\
\text { Control Plan }\end{array}$ & $\begin{array}{l}\text { Soil Erosion and Sediment Control, } \\
\text { Performance Principles (seeks to } \\
\text { retain trees and other exiting } \\
\text { vegetation whenever feasible, to } \\
\text { protect them during construction } \\
\text { and restore all areas damaged during } \\
\text { construction) }\end{array}$ & $\begin{array}{l}\text { Erosion and Sediment Control } \\
\text { Performance Principles (may require } \\
\text { protection of existing trees and vegetation) }\end{array}$ & $\begin{array}{l}\text { Erosion and Sediment Control (trees } \\
\text { and other existing vegetation shall be } \\
\text { fenced or roped off to protect trees } \\
\text { from construction equipment) }\end{array}$ & $\begin{array}{l}\text { Drainage and Erosion and Sediment } \\
\text { Control Standards (wherever feasible } \\
\text { natural vegetation shall be retained and } \\
\text { protected) }\end{array}$ \\
\hline Site Design & $\begin{array}{l}\text { Site Design Standards (calls for the } \\
\text { protection of significant trees or } \\
\text { stands of trees, or other vegetative } \\
\text { species that are rare to the area or of } \\
\text { particular horticultural or landscape } \\
\text { value) }\end{array}$ & $\begin{array}{ll}\text { - } & \text { Site Design Standards (may require } \\
\text { preservation efforts) } \\
\text { - Lot Development Standards (may require } \\
\text { preservation of existing unique features) }\end{array}$ & $\begin{array}{l}\text { Site Design Standards (significant trees } \\
\text { or stands of trees or other vegetative } \\
\text { species that are rare to the area or are of } \\
\text { particular horticultural or landscape } \\
\text { value are preferred areas of preservation } \\
\text { in site design) }\end{array}$ & $\begin{array}{l}\text { Lot Development Standards } \\
\text { (preservation of unique natural and/or } \\
\text { historic features such as trees or stone } \\
\text { walls may be required for } 2 \text { lot minor } \\
\text { subdivisions) } \\
\text { - Site Design Standards (call for specific } \\
\text { areas to be preserved as open space } \\
\text { including significant trees or stands of } \\
\text { trees, or other vegetative species that } \\
\text { are rare to the area or are of particular } \\
\text { horticultural or landscape value; } \\
\text { development should be laid out to } \\
\text { reduce cut and fill) }\end{array}$ \\
\hline Site Plan Review & $\begin{array}{l}\text { Development Plan Review (The } \\
\text { landscape shall be preserved in its } \\
\text { natural state, insofar as } \\
\text { environmentally desirable, by } \\
\text { minimizing tree and soil removal) zo }\end{array}$ & & & $\begin{array}{l}\text { - Site Plan Review (The landscape shall } \\
\text { be preserved in its natural state, insofar } \\
\text { as environmentally desirable, by } \\
\text { minimizing tree and soil removal) zo }\end{array}$ \\
\hline Other & $\begin{array}{l}\text { Residential Cluster (requires } \\
\text { easement around perimeter to } \\
\text { preserve existing trees and } \\
\text { vegetation) zo } \\
\text { A } 50 \text { foot perimeter no cut buffer } \\
\text { required for outer lots adjacent to a } \\
\text { public street }\end{array}$ & & $\begin{array}{l}\text { Unlawful Cutting of Trees or Shrubs } \\
\text { (unless authorized in writing by the } \\
\text { Public Works Director, trees or other } \\
\text { vegetation cannot be removed to } \\
\text { increase the visibility of a sign) }\end{array}$ & $\begin{array}{l}\text { Design and Public Improvement } \\
\text { Standards (street design standards call } \\
\text { for conservation of existing trees } \\
\text { where feasible) }\end{array}$ \\
\hline
\end{tabular}


REGULATORY COMPARISON BY NATURAL RESOURCE AREA AND PROTECTION MEASURE

\begin{tabular}{|c|c|c|c|c|}
\hline $\begin{array}{c}\text { Natural Resource } \\
\text { Protection }\end{array}$ & Richmond & South Kingstown & Westerly & West Greenwich \\
\hline
\end{tabular}

\begin{tabular}{|c|c|c|c|c|}
\hline Coastal Features & & & & \\
\hline $\begin{array}{l}\text { Erosion and Sediment } \\
\text { Control }\end{array}$ & $\bullet$ & $\begin{array}{l}\text { Erosion and Sediment Control } \\
\text { Performance Principles (Plan is required } \\
\text { for all subdivisions if construction } \\
\text { activities are within } 100 \text { feet of a wetland } \\
\text { or coastal feature) }\end{array}$ & $\begin{array}{l}\text { - Erosion and Sediment Control Plan } \\
\text { (required for all development within } 200 \\
\text { feet of any wetland or coastal feature) }\end{array}$ & \\
\hline Protection District & $\bullet$ & $\begin{array}{l}\text { - High Flood Danger Overlay zo } \\
\text { - Carrying Capacity Overtlay District (SAMP } \\
\text { Areas) zo }\end{array}$ & $\begin{array}{l}\text { Salt Pond Overlay zo } \\
\text { Flood Hazard Overlay District (no use } \\
\text { shall be approved which would } \\
\text { adversely affect the capacity of any } \\
\text { drainage facility or system or would } \\
\text { involve alteration of sand dunes, barrier } \\
\text { beaches, and other natural protective } \\
\text { barriers) zo }\end{array}$ & \\
\hline $\begin{array}{l}\text { Envinonmental } \\
\text { Analysis/Impact } \\
\text { Statement }\end{array}$ & $\bullet$ & $\begin{array}{l}\text { EIS (may be required if land is located on } \\
\text { Map } 5.3 \text { of the Comprehensive Plan as } \\
\text { being w within a critical or environmentally } \\
\text { sensitive area or by authority of the } \\
\text { Planning Board) }\end{array}$ & & \\
\hline Setbacks & 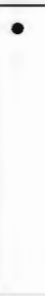 & $\begin{array}{l}\text { - Special Use Permits, Location of ISDS (no } \\
\text { facility designed to leach liquid wastes into } \\
\text { the soil shall be located within } 150 \text { feet of } \\
\text { a coastal wetland or within } 150 \text { feet of the } \\
\text { line of mean high water of any tidal water } \\
\text { body...) zo } \\
\text { Hazardous Waste Facility setback } \\
\text { requirements zo }\end{array}$ & $\begin{array}{l}\text { - Hazardous Waste Management Facility } \\
\text { Siting Requirements (prohibited within } \\
1,000 \text { feet of environmentally sensitive } \\
\text { areas) zo }\end{array}$ & \\
\hline $\begin{array}{l}\text { Land Unsuitable for } \\
\text { Development }\end{array}$ & $\bullet$ & - Land Unsuitable for Development & & \\
\hline
\end{tabular}


REGULATORY COMPARISON BY NATURAL RESOURCE AREA AND PROTECTION MEASURE

\begin{tabular}{|c|c|c|c|c|}
\hline $\begin{array}{c}\text { Natural Resource } \\
\text { Protection }\end{array}$ & Richmond & South Kingstown & Westerly & West Greenwich \\
\hline
\end{tabular}

\begin{tabular}{|l|l|l|l|}
\hline $\begin{array}{l}\text { Coastal Features } \\
\text { (continued) }\end{array}$ & & & \\
\hline Site Design & & $-\begin{array}{l}\text { Site Design Standards (may require } \\
\text { preservation as open space) }\end{array}$ & $\begin{array}{l}\text { Site Design Standards (preferred } \\
\text { preservation of coastal features in site } \\
\text { design) }\end{array}$ \\
\hline Site Plan Review & & & $\begin{array}{l}\text { Development Plan Review (required for } \\
\text { all non-residential uses--a development } \\
\text { plan shall not be approved if it would } \\
\text { result in water pollution, damage to } \\
\text { shoreline vegetation, or inhibition of } \\
\text { public access) zo }\end{array}$ \\
\hline Other & & $\begin{array}{l}\text { Special Requirements (Residential Cluster } \\
\text { in R200 may be restricted based on } \\
\text { environmental considerations) zo } \\
\text { R200 Zone (intended to protect } \\
\text { environmentally sensitive areas: aquifers, } \\
\text { recharge areas, and coastal ponds) zo }\end{array}$ & \\
\hline
\end{tabular}


REGULATORY COMPARISON BY NATURAL RESOURCE AREA AND PROTECTION MEASURE

\section{Natural Resource}

Protection

Richmond

South Kingstown

Westerly

West Greenwich

\begin{tabular}{|c|c|c|c|c|}
\hline $\begin{array}{l}\text { Village/Rural } \\
\text { Character }\end{array}$ & & & & \\
\hline Overlay Districts & & $\begin{array}{l}\text { - Architectural Standards of Review } \\
\text { Required (Historic Overlay District; Route } \\
1 \text { Special Management District) zo } \\
\text { - Historic Overlay District (includes an area } \\
\text { within the Village of Kingston) zo } \\
\end{array}$ & $\begin{array}{l}\text { Historic Overlay District } \\
\text { Bed and Breakfast/Guest House } \\
\text { Overlay District }\end{array}$ & \\
\hline $\begin{array}{l}\text { Cluster Development, } \\
\text { Residential Compounds, } \\
\text { Large Lot Zoning }\end{array}$ & $\begin{array}{l}\text { Planned Development District } \\
\text { (purpose is to foster and maintain } \\
\text { the rural character of the town) zo } \\
\text { - Residential Compounds (intended to } \\
\text { preserve the rural character of the } \\
\text { town) zo } \\
\text { - Residential Cluster Development zo }\end{array}$ & - R200 Zone & & \\
\hline Site Design & $\begin{array}{l}\text { Site Design Standards (call for } \\
\text { reasonable landscaping at site } \\
\text { entrances, in public areas, and } \\
\text { adjacent to buildings }\end{array}$ & $\begin{array}{l}\text { Site Design Standards (special provisions } \\
\text { for flexible lot size, lot lines, frontage, and } \\
\text { setbacks; calls for the placement of } \\
\text { dwelling units to take into } \\
\text { consideration...scenic values ) } \\
\text { Lot Development Standards (may require } \\
\text { the preservation of historic features such } \\
\text { as trees or stone walls) }\end{array}$ & $\begin{array}{l}\text { - Site Design Standards ( to the maximum } \\
\text { extent practicable, development shall be } \\
\text { located to preserve impacts and } \\
\text { alteration of natural features, historic } \\
\text { and cultural resources, and areas of } \\
\text { scenic value which contribute to the } \\
\text { character of town) } \\
\text { Lot Design Standards }\end{array}$ & $\begin{array}{l}\text { - Site Design Standards (call for specific } \\
\text { areas to be preserved as open space } \\
\text { including historically significant } \\
\text { structures and sites) } \\
\text { Lot Development Standards } \\
\text { (preservation of unique natural and/or } \\
\text { historic features such as trees or stone } \\
\text { walls may be required for } 2 \text { lot minor } \\
\text { subdivisions) }\end{array}$ \\
\hline Historic Preservation & & $\begin{array}{l}\text { Maintenance Standards and procedures for } \\
\text { identifying endangered buildings (Building } \\
\text { Code) }\end{array}$ & $\begin{array}{l}\text { - See Site Design and Overlay Districts } \\
\text { above }\end{array}$ & $\begin{array}{l}\text { - See Site Design and Site Plan Review } \\
\text { above }\end{array}$ \\
\hline Landscaping Standards & & & & $\begin{array}{l}\text { Design and Public Improvement } \\
\text { Standards (a landscape plan is required) }\end{array}$ \\
\hline Street Design & $\begin{array}{l}\text { - Shared Common Drives-- } \\
\text { encouraged }\end{array}$ & $\begin{array}{l}\text { - Shared Common Drives (encouraged for } \\
\text { minor } 2 \text { lot subdivisions) }\end{array}$ & & \\
\hline
\end{tabular}


APPENDIX A

List of Plans, Ordinances, and Land Development Regulations

\begin{tabular}{|l|l|l|l|}
\hline \multicolumn{1}{|c|}{ Town } & $\begin{array}{c}\text { Comprehensive } \\
\text { Plan }\end{array}$ & \multicolumn{1}{|c|}{$\begin{array}{c}\text { Zoning } \\
\text { Ordinance }\end{array}$} & \multicolumn{1}{|c|}{$\begin{array}{c}\text { Subdivision } \\
\text { Regulations }\end{array}$} \\
\hline Charlestown & January 1992 & $\begin{array}{l}\text { With amendments } \\
\text { to 1998 }\end{array}$ & October 18, 1995 \\
\hline Coventry & June 2000 & $\begin{array}{l}\text { With amendments } \\
\text { through June 26, } \\
\text { 2000 }\end{array}$ & December 13, 1995 \\
\hline Exeter & July 1994 & $\begin{array}{l}\text { With amendments } \\
\text { through August 3, } \\
2000\end{array}$ & December 12, 1995 \\
\hline Hopkinton & September 1992 & December 19, 1994 & November 29, 1995 \\
\hline Richmond & December 1991 & $\begin{array}{l}\text { With amendments } \\
\text { through February } \\
\text { 1998 }\end{array}$ & February 15, 2000 \\
\hline South \\
Kingstown & July 1992 & $\begin{array}{l}\text { With amendments } \\
\text { through May 10, } \\
\text { 1999 }\end{array}$ & November 9, 1999 \\
\hline West Greenwich & December 1995 & $\begin{array}{l}\text { With amendments } \\
\text { through July 1998 }\end{array}$ & November 6, 2000 \\
\hline Westerly & January 1992 & October 16, 1998 & $\begin{array}{l}\text { September 11, } \\
1997\end{array}$ \\
\hline
\end{tabular}




\section{APPENDIX B}

Municipal Planners

\begin{tabular}{|l|l|}
\hline \multicolumn{1}{|c|}{ Town } & \multicolumn{1}{c|}{ Planner Interviewed } \\
\hline Charlestown & Nancy Hess \\
\hline Coventry & Brent Narkawicz \\
\hline Exeter & George Caldow \\
\hline Hopkinton & Katherine Maxwell \\
\hline Richmond & Joseph Lombardo \\
\hline South Kingstown & Anthony Lachowicz \\
\hline West Greenwich & John Pagliarini, Jr. \\
\hline Westerly & Joseph Lombardo \\
\hline
\end{tabular}

